NISTIR 6646

\title{
Thermophysical Properties Measurements and Models for Rocket Propellant RP-1: Phase I
}

Joseph W. Magee

Thomas J. Bruno

Daniel G. Friend

Marcia L. Huber

Arno Laesecke

Eric W. Lemmon

Mark O. McLinden

Richard A. Perkins

Jörg Baranski

Jason A. Widegren

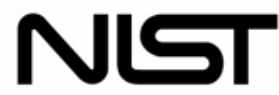




\section{Thermophysical Properties Measurements and Models for Rocket Propellant RP-1: Phase I}

Joseph W. Magee Thomas J. Bruno Daniel G. Friend Marcia L. Huber Arno Laesecke Eric W. Lemmon Mark O. McLinden Richard A. Perkins Jörg Baranski Jason A. Widegren

Physical and Chemical Properties Division Chemical Science and Technology Laboratory

February 2007

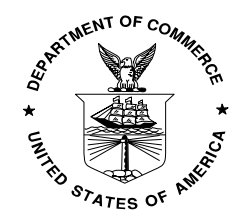

U.S. Department of Commerce Carlos M. Gutierrez, Secretary

Technology Administration Robert C.Cresanti, Undersecretary for Technology

National Institute of Standards and Technology William A. Jeffrey, Director 


\section{CONTENTS}

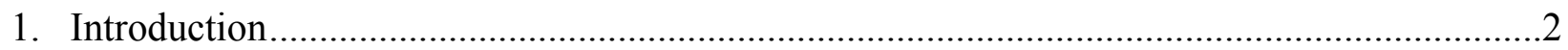

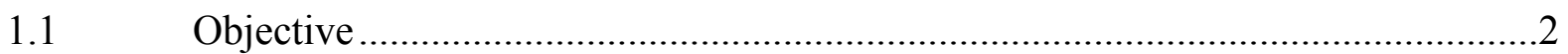

$1.2 \quad$ Scope

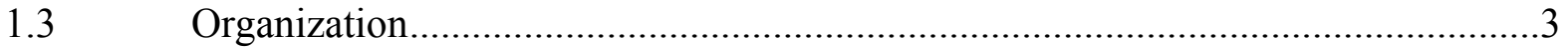

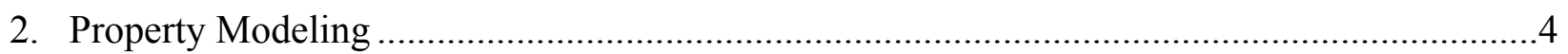

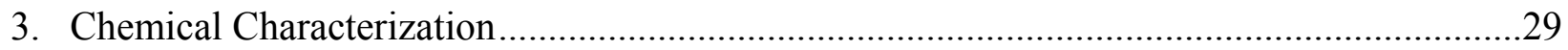

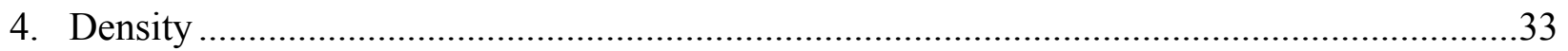

4.1 Density at Atmospheric Pressure ......................................................................33

4.2 Density at Elevated Pressures ...........................................................................

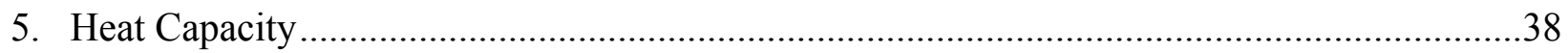

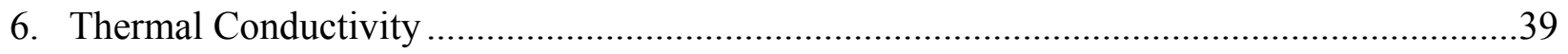

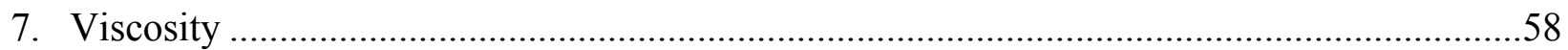

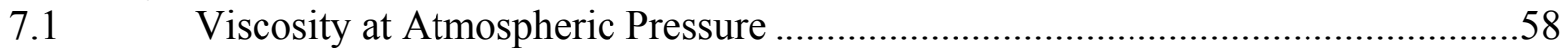

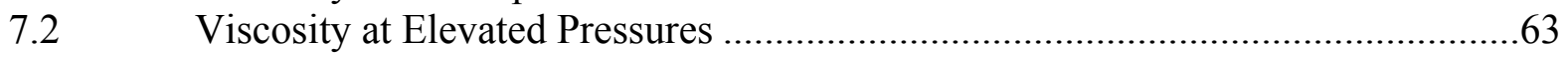

8. Project Workshop at NIST Boulder on December 11, $2003 \ldots \ldots \ldots \ldots \ldots \ldots \ldots \ldots \ldots \ldots \ldots \ldots \ldots \ldots \ldots \ldots \ldots . . . .69$

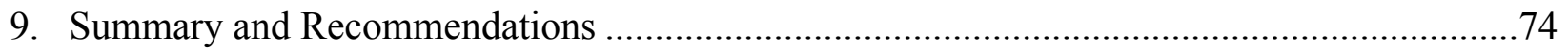

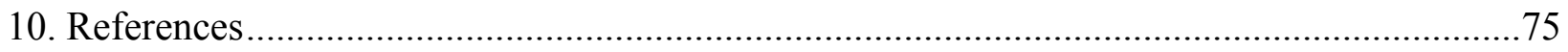

Appendix A. Discussion of Chemical Characterization ..............................................................104

Appendix B. Computational Characterization of Surrogate Mixture Compounds .......................109 


\section{List of Tables}

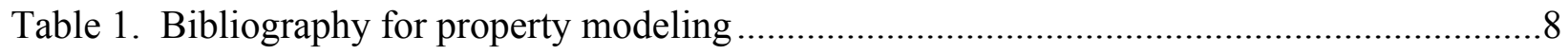

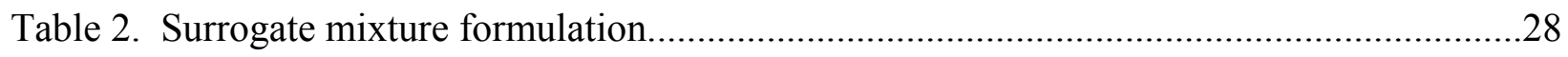

Table 3. Tier 1 - Identification of constituents of $2 \%$ (mass/mass) or higher ..........................30

Table 4. Tier 2-Identification of constituents of $1 \%$ (mass/mass) or higher ...........................31

Table 5. Light fraction-identification of constituents of lightest components ..........................32

Table 6. Heavy fraction-identification of constituents of heaviest components ........................32

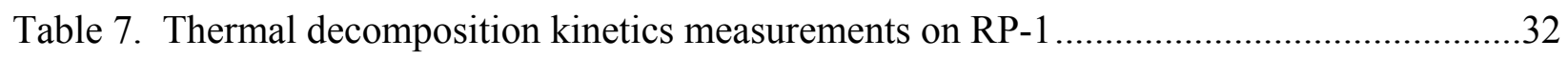

Table 8. Experimental densities for RP-1 (original sample) under nitrogen ..............................35

Table 9. Experimental densities for RP-1 (ultra-low sulfur) under nitrogen ............................35

Table 10. Thermal conductivity of liquid RP-1 ........................................................... 47

Table 11. Experimental kinematic viscosities for four RP-1 samples .................................61

Table 12. Experimental viscosity measurements at elevated pressures.................................66

Table 13. Participants in NIST Rocket Propellant Workshop ..............................................70 


\section{List of Figures}

Figure 1. Density of RP-1 at atmospheric pressure; (a) measured densities; (b) deviations of density from the simple polynomial correlation

Figure 2. Range of thermal conductivity measurements on liquid RP-1

Figure 3. Thermal conductivity of RP-1 corrected for thermal radiation (pressure from $0.1 \mathrm{MPa}$ to $70 \mathrm{MPa}$ 45

Figure 4. Empirical optical parameters for radiation correction of RP-1 data.. .45

Figure 5. Solid deposits with diameters up to 8 times that of the $4 \mu \mathrm{m}$ hot wires were found after measurements on RP-1 at $650 \mathrm{~K}$

Figure 6. Deviations between the radiation corrected thermal conductivity data and the corresponding-states model for RP-1 developed in this work

Figure 7. (a) Kinematic viscosity of the original sample of RP-1 as a function of temperature; (b) Arrhenius plot of the same data, solid curve is a correlation; (c) deviations of kinematic viscosity from the correlation.

Figure 8. Percent deviations of the kinematic viscosity of three rocket propellant samples compared to the correlation for the kinematic viscosity of the original sample of RP-1

Figure 9. (Viscosity $\times$ density) product of RP-1 at elevated pressures measured in the torsional crystal viscometer at room temperature and at $400 \mathrm{~K}$

Figure 10. Percent deviations of the measured viscosities of RP-1 at elevated pressures from the model for the surrogate mixture

Figure 11. Molecular representation of 2,2-dimethylbutane ………........................................110

Figure 12. Molecular representation of 3-ethyl-4,4-dimethyl-2-pentene …................................110

Figure 13. Molecular representation of cyclodecene ..........................................................111

Figure 14. Molecular representation of cis-decaline..........................................................111

Figure 15. Molecular representation of 2-methylnonane.......................................................112

Figure 16. Molecular representation of 2-methylnaphthalene ....................................................112

Figure 17. Molecular representation of decahydro-2-methylnaphthalene .................................113

Figure 18. Molecular representation of 3-methyldecane ……….................................................113 
Figure 19. Molecular representation of 1-dodecene ........................................................114

Figure 20. Molecular representation of 1,11-dodecadiene ..................................................114

Figure 21. Molecular representation of cyclododecane .................................................115

Figure 22. Molecular representation of heptylcyclohexane.................................................115

Figure 23. Molecular representation of $n$-dodecane .........................................................116

Figure 24. Molecular representation of methylcyclododecane ...........................................116

Figure 25. Molecular representation of 1-tridecene.......................................................117

Figure 26. Molecular representation of 2,10-dimethylundecane ........................................117

Figure 27. Molecular representation of 2,7,10-trimethyldodecane.....................................118

Figure 28. Molecular representation of n-hexadecane...................................................118 


\section{THERMOPHYSICAL PROPERTIES MEASUREMENTS AND MODELS FOR ROCKET PROPELLANT RP-1: PHASE I}

Joseph W. Magee, Thomas J. Bruno, Daniel G. Friend, Marcia L. Huber, Arno Laesecke, Eric W. Lemmon, Mark O. McLinden, Richard A. Perkins, Jörg Baranski, and Jason A. Widegren Physical and Chemical Properties Division Chemical Science and Technology Laboratory National Institute of Standards and Technology

Boulder, Colorado 80305-3328

Accurate knowledge of thermophysical properties is a prerequisite to the design of efficient and cost-effective rocket engine systems that use the kerosene rocket propellant designated RP-1. A robust properties model that is based on reliable experimental measurements is the best means to provide this information to designers. Thus, a combined experimental and modeling study was carried out to elucidate the behavior of key properties over wide ranges of temperature and pressure. As a first step in this study, an RP-1 sample provided by the U.S. Air Force Research Lab (Wright-Patterson AFB, OH) was chemically characterized, which established that this sample had anomalously high concentrations of unsaturated compounds. Then, thermophysical properties were measured for this sample. Those experimental results were used to develop a mixture model based on a representative surrogate mixture. The results of this study were presented for review and comments during a December 11, 2003 workshop attended by representatives of NASA, U.S. Air Force, and their contractors.

Key words: chemical characterization; density; heat capacity; Helmholtz energy; hydrocarbons; mixture model; rocket propellant RP-1; surrogate mixture; thermal conductivity; viscosity 


\section{Introduction}

\subsection{Objective}

Among the long-range objectives of research in thermophysical properties at the National Institute of Standards and Technology (NIST) is the development of accurate predictive methods for calculating the properties of gaseous and liquid mixtures of hydrocarbons. The underlying models may play a key role in design of equipment that is used in the transportation and energy sectors and for optimization of materials and energy usage. The ongoing development and testing of these models relies heavily on benchmark experimental measurements. The purpose of this report is to provide design engineers, data analysts, and experimentalists with a compilation of recent studies of the thermophysical properties for rocket propellant RP-1, a real fuel that is a complex hydrocarbon mixture. It is a well established fact that thermophysical properties of a complex mixture can vary considerably with composition. This report is denoted as Phase I since it covers thermophysical properties of the first sample of this real fuel that was furnished to NIST, with an expectation that studies of other samples would follow in Phases II, III, etc., until NIST had developed a robust compositionally variable model that was based on the measurements. The studies were carried out, during calendar year 2003, by the staff of the Experimental Properties of Fluids Group, the Theory and Modeling of Fluids Group, and the Properties for Process Separations Project, all of which are units of the Physical and Chemical Properties Division of the Chemical Science and Technology Laboratory (CSTL) of NIST. We begin with a report of the modeling effort because, while the model was the end product, its discussion provides a framework for the rest of the work. Following the models section, we present details of the underlying experimental measurements of chemical character, density, heat capacity, thermal conductivity and viscosity.

\subsection{Scope}

Knowledge of thermophysical properties is essential when a detailed analysis of the design 
and performance of a rocket propulsion system is needed. Both thermodynamic and transport properties are required. The present work stemmed from NASA's expressed need for accurate thermophysical properties that cover wide ranges of temperature and pressure. This property information is needed for a rational design of highly reliable reusable rocket engines for future launch vehicles in which the fuels are expected to encounter higher pressures and temperatures than in those previous designs. NASA's sensitivity study had concluded that property uncertainties accounted for $70 \%$ of the uncertainty in a portion of the propulsion system design. NASA had also noted that, prior to this project, experimental data covered only limited ranges of conditions and, furthermore, the differences in RP-1 properties from different sources amounted to as much as $60 \%$.

To meet NASA's needs and expand knowledge in the field of kerosene-based fuels, a comprehensive program was planned and carried out. This program had both measurement and modeling components. Those results are the subject of this report.

\subsection{Organization}

This report is arranged in nine sections and begins with a discussion of property models. The modeling results are followed by those of measured thermophysical properties: chemical characterization, density, heat capacity, thermal conductivity, and viscosity. The experimental measurements are presented in tables and graphs. The report concludes with a discussion of a NIST workshop, some impacts of this research program, and recommendations for further studies. Section 10 following this report lists references, Appendix A details procedures for chemical analyses, and Appendix B reports computational results for the compounds in a surrogate fuel mixture. 


\section{Property Modeling}

Since RP-1 is a complex mixture of several hundred components, modeling its properties using equations for the constituents of the mixture is not a practical solution. An alternative approach is to model the fuel as a surrogate mixture of between 10 and 20 components that can represent the thermodynamic and transport properties of the actual RP-1 fluid. Both thermodynamic properties (such as density, heat capacity, and normal boiling point) and transport properties (including thermal conductivity and viscosity) may be used in model development.

The first step in the modeling process was a chemical analysis (see Section 3) of a specific RP-1 fuel sample provided by the Fuels Branch of the Air Force Research Lab, Wright-Patterson AFB, OH. The analysis used a gas-chromatography mass/ spectrometry method and provided 37 constituent fluids. A detailed analysis shortened this list to 20 potential constituent fluids for a surrogate mixture. The lightest component identified was neohexane, and the heaviest was hexadecane. The list included linear and branched alkanes, mono and bicyclic paraffins, aromatics, and linear and branched olefins. For each of these fluids, we searched the open literature as well as databases such as TRC-SOURCE, DIPPR, Landolt-Bornstein, and NIST in-house databases for experimental physical property data. A bibliography of the results of these searches was constructed and is given in Table 1. In addition, we used predictive methods when data were not available.

In order to model the thermodynamic properties of these fluids, an equation of state of some form was required. Because of the very limited amount of data available, a generalized method was selected to describe the attributes of the fluids. A short form of a Helmholtz energy equation of state was used as a starting point. The equation is expressed with reducing variables, with the critical temperature and critical density of the fluid as the primary reducing properties. 
The equation has 12 terms, and the coefficients of the equation are functions of the acentric factor. Experimental data for the normal alkanes from butane through hexatriacontane (C36) were fitted to determine the coefficients of the equation ( 48 in all, since each coefficient uses 4 parameters that are functions of the acentric factor). The experimental data included densities, vapor pressures, heat capacities, and sound speeds. Comparisons were made against data for both the normal alkanes as well as branched alkanes (which were not fitted) to determine that the final equation could successfully be applied to these hydrocarbons.

The generalized equation was then used to make equations for each of the 20 fluids in the surrogate. Only the critical temperature, critical density, and acentric factor are required to set up an equation for each component. The critical temperatures were taken from the literature or estimated from prediction schemes. The critical density and acentric factor were fitted using experimental vapor pressures at the boiling point and saturated liquid densities near atmospheric conditions. For fluids with additional data at other state points, the values of the critical density and acentric factor could be more closely tuned to achieve lower overall uncertainties. Viscosity and thermal conductivity surfaces for each of the constituent fluids were developed from experimental data, predictive methods, and an extended corresponding states model from sources summarized in Table 1.

The next step was to select a method for representing the properties of the RP-1 mixture. For the thermodynamic properties, we selected an excess Helmholtz energy mixture model used successfully at NIST for the representation of properties of natural gas and refrigerant mixtures $[1,2]$. The model uses the pure fluid equations of state with ideal mixing to account for most of the mixture properties. To account for the additional interaction between unlike molecules, an excess contribution can be used to account for the remainder of the mixture properties. However, 
experimental information for each binary system in the mixture is needed to determine the excess contribution. Since experimental data are not available, the excess part was set to zero. There are two additional parameters in the mixture model that can be adjusted to achieve better results. A general scheme had been developed in previous work at NIST to predict one of these parameters for systems where no data are available. This scheme was used here to improve the mixture calculations.

For transport properties, we use an extended corresponding states model $[3,4]$. In this approach, the properties of the mixture are represented in a two-step process that involves mapping onto a reference fluid. The reference fluid may be any well characterized fluid, but it is best to select a reference fluid that is chemically similar to the constituents of the mixture of interest. For this work, we chose n-dodecane as a reference fluid. Since it is important to have a very good representation of both the thermodynamic and transport properties of the reference fluid, as part of this project we developed a dedicated equation of state for $\mathrm{n}$-dodecane and correlations for the viscosity and thermal conductivity. The results of this work are available as two publications in the journal Energy and Fuels [5,6]. The correlations for n-dodecane are valid over a wide range of fluid states, from the triple point to the onset of decomposition, and for pressures to $200 \mathrm{MPa}$. Uncertainties of properties calculated using the equation are $0.2 \%$ in density at pressures up to 200 $\mathrm{MPa}, 0.5 \%$ at higher pressures (up to $500 \mathrm{MPa}$ ), $1 \%$ in heat capacities, $0.5 \%$ in sound speeds, and $0.2 \%$ in vapor pressures. The viscosity correlation has an estimated uncertainty of $0.5 \%$ along the saturation boundary in the liquid phase, $3 \%$ in the compressed liquid region, and $2 \%$ in the vapor. The thermal conductivity has an estimated uncertainty of $3 \%$ along the liquid saturation boundary and in the compressed liquid phase, and $5 \%$ in the vapor region.

The final step in the modeling procedure was to determine the compositions of the 
constituent fluids that best represent the properties of the mixture. The properties that we selected for fitting were experimental densities, heat capacities, thermal conductivities, viscosities, and one boiling point that were measured as part of this work, described in separate sections of this report. Data at temperatures above $600 \mathrm{~K}$ were not used in the fitting process due to concerns about thermal decomposition during the measurements. A multi-property fitting routine was used to determine the compositions of the constituents of the surrogate mixture. The final mixture, summarized in Table 2, contains 14 constituent fluids, and represents the density to within $0.3 \%$, the heat capacity to within $7 \%$, the thermal conductivity to within $3 \%$, the viscosity to within $3 \%$ at atmospheric pressures and $10 \%$ at $60 \mathrm{MPa}$, and the boiling point at local atmospheric pressure to $0.5 \%$. It has an overall molar mass of 164.6 , a hydrogen to carbon ratio $(\mathrm{H} / \mathrm{C})$ of 1.95 , and an approximate chemical formula of $\mathrm{C}_{11.8} \mathrm{H}_{23.0}$. The overall composition is (by mole \%) $27.4 \%$ alkanes, $26.6 \%$ alkenes, $18.5 \%$ monocyclic paraffins, $22.4 \%$ bicyclic paraffins, and $5.1 \%$ aromatics. This mixture is a surrogate; it is not the actual mixture composition, but rather a mixture that approximates the behavior of the RP-1 sample that was investigated. 
Table 1. Bibliography for property modeling.

Fuel Decomposition Studies

\begin{tabular}{|c|c|c|}
\hline Author(s) & Reference & Topic \\
\hline Andresen et al. & {$[7]$} & Solids formation jet fuels \\
\hline Balster and Jones & [8] & Formation of insolubles in aviation fuels \\
\hline Batti & [9] & Thermal stability jet fuels \\
\hline Behar et al. & [10] & Thermal decomposition of dodecylbenzene \\
\hline Chin et al. & [11] & Thermal stability of four kerosine-type fuels \\
\hline Chin and Lefebvre & [12] & $\begin{array}{l}\text { For characterizing the thermal oxidative tendencies of } \\
\text { aviation fuels }\end{array}$ \\
\hline Chin and Lefebvre & [13] & Thermal stability characteristics of kerosine-type fuels \\
\hline Chin and Lefebvre & [14] & Thermal stability characteristics of hydrocarbon fuels \\
\hline $\begin{array}{l}\text { Edwards and } \\
\text { Zabarnick }\end{array}$ & [15] & Surface deposition (fouling) of jet fuels \\
\hline Giovanetti et al. & [16] & $\begin{array}{l}\text { Thermal stability and heat-transfer characteristics of several } \\
\text { hydrocarbon fuels }\end{array}$ \\
\hline Goel and Boehman & {$[17]$} & Jet fuel degradation in flow reactors \\
\hline $\begin{array}{l}\text { Grinstead and } \\
\text { Zabarnick }\end{array}$ & [18] & Oxidn. and deposition data for jet fuels \\
\hline Han-Ying & [19] & Thermal stability of kerosene \\
\hline Heneghan et al. & [20] & Jet fuel thermal stability \\
\hline $\begin{array}{l}\text { Heneghan and } \\
\text { Harrison }\end{array}$ & [21] & development of an improved JP-8 \\
\hline Hines & [22] & Heat transfer to RP-1 kerosine \\
\hline Kendall and Mills & [23] & Thermal stability of aviation kerosines \\
\hline Lai and Song & [24] & Pyrolization of cyclohexane and seven n-alkylcyclohexanes \\
\hline Liang et al. & {$[25]$} & $\begin{array}{l}\text { Heat transfer characteristics of methane, propane, kerosene, } \\
\text { aerokerosene and rocket kerosene }\end{array}$ \\
\hline $\mathrm{Ma}$ & [26] & Thermal stability of kerosine \\
\hline $\begin{array}{l}\text { Marteney and } \\
\text { Spadaccini }\end{array}$ & [27] & Thermal stability of jet fuels \\
\hline Pande and Hardy & {$[28]$} & Soluble copper and stability \\
\hline Roback et al. & [29] & Deposit formation in hydrocarbon fuels \\
\hline Savage et al. & {$[30]$} & $\begin{array}{l}\text { Review of fundamental studies and applications of reactions } \\
\text { at supercritical conditions }\end{array}$ \\
\hline Stekhun & [31] & Effect of hydrofining on thermal stability of jet fuels \\
\hline Stewart et al. & [32] & Supercritical pyrolysis of decalin, tetralin, n-decane \\
\hline Stiegemeier & [33] & $\begin{array}{l}\text { Thermal Stability and Heat Transfer Investigation of Five } \\
\text { Hydrocarbon Fuels }\end{array}$ \\
\hline Wang & {$[34]$} & Thermophysics characterization of kerosene combustion \\
\hline $\begin{array}{l}\text { Watkinson and } \\
\text { Wilson }\end{array}$ & {$[35]$} & Review of fouling of organic fluids \\
\hline Wohlwend et al. & [36] & Thermal stability of RP-1, JP-10, and quadricyclane \\
\hline
\end{tabular}




\begin{tabular}{|l|r|l|}
\hline Author(s) & Reference & Topic \\
\hline Yu and Eser & {$[37]$} & Critical points of jet fuels \\
\hline Yu and Eser & {$[38]$} & Thermal decomposition C10-C14 normal alkanes \\
\hline Yu and Eser & {$[39]$} & $\begin{array}{l}\text { Kinetics of thermal decomposition of C10-C14 normal } \\
\text { alkanes }\end{array}$ \\
\hline Yu and Eser & {$[40]$} & n-butylbenzene and n-butylcyclohexane \\
\hline Yu and Eser & {$[41]$} & Thermal decomposition of decalin, tetralin \\
\hline Yu and Eser & {$[42]$} & $\begin{array}{l}\text { Thermal decomposition of binary mixtures of jet fuel model } \\
\text { compounds }\end{array}$ \\
\hline $\begin{array}{l}\text { Volokhova and } \\
\text { Zhorov }\end{array}$ & {$[43]$} & Pyrolysis of Russian kerosene \\
\hline
\end{tabular}

\section{Surrogate Models}

\begin{tabular}{|l|r|l|}
\hline Author(s) & Reference & Topic \\
\hline Edwards and Maurice & {$[44]$} & JP-4, JP-8, JP-5, RP-1 surrogates \\
\hline Edwards & {$[45]$} & Surrogates, general petroleum distillate fuels \\
\hline Farmer et al. & {$[46]$} & RP-1 surrogate \\
\hline Patterson et al. & {$[47]$} & Kerosene surrogate \\
\hline Violi et al. & {$[48]$} & JP-8 surrogate \\
\hline Wang & {$[49]$} & Kerosene/RP-1 surrogate \\
\hline Wood et al. & {$[50]$} & JP-4 surrogate \\
\hline
\end{tabular}

\section{RP-1/kerosene Properties}

\begin{tabular}{|l|r|l|}
\hline Author(s) & Reference & Topic \\
\hline Alexander et al. & {$[51]$} & Index of refraction \\
\hline Blake and Sheard & {$[52]$} & Dielectric constant, kerosene \\
\hline Chao & {$[53]$} & Isothermal compressibility \\
\hline CPIA/M4 & {$[54]$} & $\begin{array}{l}\text { Properties of RP-1 including vapor pressure, density, } \\
\text { viscosity, boiling point, fractional distillation curve, specific } \\
\text { heat, thermal conductivity, composition }\end{array}$ \\
\hline Dubovkin et al. & {$[55]$} & Vapor pressure, critical parameters Russian fuels \\
\hline Kopylov & {$[56]$} & Viscosity, Russian T-1 kerosene \\
\hline Kozyokov & {$[57]$} & Thermal conductivity, Russian T-1 kerosene \\
\hline Liang et al. & {$[25]$} & Heat transfer characteristics of kerosene \\
\hline Mehta et al. & {$[58]$} & $\begin{array}{l}\text { Specific Gravity, viscosity, boiling point, chemical analysis } \\
\text { of Russian kerosene }\end{array}$ \\
\hline Piatibratov & {$[59]$} & Density, Russian T-1 kerosene \\
\hline Sharma et al. & {$[60]$} & Correlation for flash point of kerosene \\
\hline Sokolov and Tarlakov & {$[61]$} & Heat capacity, Russian T-1 kerosene \\
\hline Sokolov and Tarlakov & {$[62]$} & Vapor pressure, Russian T-1 kerosene \\
\hline Stiegemeier & {$[63]$} & RP-1, JP-7, JP-8, JP-8+100, JP-10 thermal stability \\
\hline
\end{tabular}




\begin{tabular}{|l|r|l|}
\hline Author(s) & Reference & Topic \\
\hline Vinogradov & {$[64]$} & Density, sound speed, viscosity of kerosene \\
\hline Volyak & {$[65]$} & Surface tension, Russian T-1 kerosene \\
\hline Wohlwend et al. & {$[36]$} & Thermal stability measurements RP-1, JP-10, quadricyclane \\
\hline Wucherer and Wilson & {$[66]$} & Density, thermal conductivity \\
\hline Zaytseva & {$[67]$} & Thermal conductivity, Russian T-1 kerosene \\
\hline
\end{tabular}

\section{Estimation methods}

\begin{tabular}{|l|r|l|}
\hline Author(s) & Reference & Topic \\
\hline $\begin{array}{l}\text { American Petroleum } \\
\text { Institute }\end{array}$ & {$[68]$} & viscosity, thermal conductivity \\
\hline Baroncini et al. & {$[69]$} & Thermal conductivity \\
\hline Chung et al. & {$[70]$} & Lennard-Jones parameters, viscosity, thermal conductivity \\
\hline $\begin{array}{l}\text { Constantinou and } \\
\text { Gani }\end{array}$ & {$[71]$} & Critical point, boiling point \\
\hline Deppmeier et al. & {$[72]$} & Dipole moment, radius of gyration \\
\hline Ely and Hanley & {$[73,74]$} & Viscosity, thermal conductivity \\
\hline Horvath & {$[75]$} & $\begin{array}{l}\text { Critical point, boiling point, melting point, heat capacity, } \\
\text { thermal conducitivty, viscosity }\end{array}$ \\
\hline Joback & {$[76]$} & Critical point, boiling point, melting point \\
\hline Marrero & {$[77]$} & Critical point, boiling point \\
\hline Poling et al. & {$[78]$} & $\begin{array}{l}\text { Critical point, boiling point, melting point, heat capacity, } \\
\text { thermal conducitivy, viscosity }\end{array}$ \\
\hline Quayle & {$[79]$} & Parachors \\
\hline $\begin{array}{l}\text { Rihani and } \\
\text { Doraiswamy }\end{array}$ & {$[80]$} & Heat capacity \\
\hline Stein and Brown & {$[81]$} & Heat capacity \\
\hline Wilson and Jasperson & {$[82]$} & Critical point, boiling point \\
\hline Yan et al. & {$[83]$} & Critical point \\
\hline
\end{tabular}

Potential Components in the Surrogate Model

\section{Cyclododecane}

\begin{tabular}{|l|r|l|}
\hline Author(s) & Reference & Topic \\
\hline Coops et al. & {$[84]$} & Melting point \\
\hline Drotloff and Moller & {$[85]$} & Melting point \\
\hline Fischer and Weiss & {$[86]$} & $\begin{array}{l}\text { Viscosity, density, melting point, boiling point, self-diffusion } \\
\text { coefficient }\end{array}$ \\
\hline Gollis et al. & {$[87]$} & Viscosity \\
\hline Ladygin et al & {$[88]$} & Viscosity \\
\hline Matteoli et al. & {$[89]$} & Density \\
\hline
\end{tabular}




\begin{tabular}{|l|r|l|}
\hline Author(s) & Reference & Topic \\
\hline Meyer and Hotz & {$[90]$} & Density, vapor pressure \\
\hline Mueller et al & {$[91]$} & Melting point \\
\hline Ruzicka et al. & {$[92]$} & Density \\
\hline
\end{tabular}

\section{Methylcyclododecane}

Estimated properties

\section{Cyclodecene}

\begin{tabular}{|l|r|l|}
\hline Author(s) & Reference & Topic \\
\hline Allinger & {$[93]$} & Boiling point \\
\hline Blomquist et al. & {$[94]$} & Density, boiling point \\
\hline Cope et al. & {$[95]$} & Boiling point \\
\hline Prelog et al. & {$[96]$} & Boiling point \\
\hline
\end{tabular}

\section{2,10-dimethylundecane}

\begin{tabular}{|l|r|l|}
\hline Author(s) & Reference & Topic \\
\hline Gibbons & {$[97]$} & boiling point \\
\hline
\end{tabular}

2,7,10-trimethyldodecane

Estimated values

\section{3-methylundecane}

\begin{tabular}{|l|r|l|}
\hline Author(s) & Reference & Topic \\
\hline Levene and Harris & {$[98]$} & Density, boiling point \\
\hline Mann et al. & {$[99]$} & Density \\
\hline Marsh et al. & {$[100]$} & Heat capacity \\
\hline Petrov et al. & {$[101]$} & Melting point, density, boiling point \\
\hline Prout et al. & {$[102]$} & Boiling point \\
\hline Smith & {$[103]$} & Boiling point \\
\hline Terres et al. & {$[104]$} & Melting point \\
\hline
\end{tabular}

\section{2,9-dimethyldecane}

\begin{tabular}{|l|r|l|}
\hline Author(s) & Reference & Topic \\
\hline Calingaert and Soroos & {$[105]$} & Density, boiling point \\
\hline
\end{tabular}




\begin{tabular}{|l|r|l|}
\hline Author(s) & Reference & Topic \\
\hline Calingaert and Soroos & {$[106]$} & Density \\
\hline Dyke and Jones & {$[107]$} & Boiling point \\
\hline Eykman & {$[108]$} & Density \\
\hline Geist and Cannon & {$[109]$} & Density, viscosity \\
\hline Mears et al. & {$[110]$} & Density, boiling point, melting point \\
\hline Moore et al. & {$[111]$} & Density \\
\hline Parks et al. & {$[112]$} & Triple point, melting point \\
\hline
\end{tabular}

\section{2-methylnonane}

\begin{tabular}{|l|r|l|}
\hline Author(s) & Reference & Topic \\
\hline $\begin{array}{l}\text { Calingaert and } \\
\text { Hladky }\end{array}$ & {$[113]$} & Density \\
\hline Calingaert and Soroos & {$[105]$} & Boiling point, density \\
\hline Eykman & {$[108]$} & Density \\
\hline Geist and Cannon & {$[109]$} & Viscosity, density \\
\hline Marsh et al. & {$[100]$} & Heat capacity \\
\hline Mears et al. & {$[110]$} & Boiling point, freezing point \\
\hline Moore et al & {$[111]$} & Density \\
\hline Parks et al. & {$[112]$} & Triple point \\
\hline
\end{tabular}

\section{3-methyldecane}

\begin{tabular}{|l|r|l|}
\hline Author(s) & Reference & Topic \\
\hline Marsh et al. & {$[100]$} & Heat capacity \\
\hline
\end{tabular}

\section{3-ethyl-4,4-dimethyl-2-pentene}

\begin{tabular}{|l|r|l|}
\hline Author(s) & Reference & Topic \\
\hline Howard et al. & {$[114]$} & Density, boiling point \\
\hline
\end{tabular}

\section{4-methyl-4-undecene}

Estimated values

\section{2-methylnaphthalene}

\begin{tabular}{|l|r|l|}
\hline Author(s) & Reference & Topic \\
\hline Ambrose & {$[115]$} & Critical temperature \\
\hline Briggs & {$[116]$} & Thermal conductivity \\
\hline Byers and Williams & {$[117]$} & Viscosity \\
\hline
\end{tabular}




\begin{tabular}{|l|r|l|}
\hline Author(s) & Reference & Topic \\
\hline Camin and Rossini & {$[118]$} & Vapor pressure \\
\hline Coulson & {$[119]$} & Boiling point \\
\hline Cullinane and Chard & {$[120]$} & Freezing point \\
\hline Cumper et al. & {$[121]$} & Freezing point \\
\hline Evans & {$[122]$} & Viscosity, density \\
\hline Glaser and Ruland & {$[123]$} & Vapor pressure \\
\hline Grodde & {$[124]$} & Density \\
\hline Grosse and Ipatieff & {$[125]$} & Boiling point \\
\hline Hales and Townsend & {$[126]$} & Density \\
\hline Huffman et al. & {$[127]$} & Triple point \\
\hline Koelbel & {$[128]$} & Viscosity, boiling point \\
\hline Larsen et al. & {$[129]$} & Freezing point \\
\hline Luther and Wachter & {$[130]$} & Boiling point \\
\hline Mair and Streiff & {$[131]$} & Density, boiling point, melting point \\
\hline Marsh et al. & {$[100]$} & Heat capacity \\
\hline Neuhaus & {$[132]$} & Density \\
\hline Parks and Huffman & {$[133]$} & Freezing point \\
\hline Rampolla and Smyth & {$[134]$} & Viscosity, density, freezing point \\
\hline Salceanu & {$[135]$} & Density \\
\hline Schiessler & {$[136]$} & Viscosity \\
\hline Shreve and Lux & {$[137]$} & Density \\
\hline Sirotenko, A.A. & {$[138]$} & Viscosity \\
\hline Skvarchenko et al. & {$[139]$} & Boiling point, freezing point \\
\hline Smyth & {$[140]$} & Viscosity \\
\hline Streiff et al. & {$[141]$} & Freezing point \\
\hline Szafranski & {$[142]$} & Freezing point \\
\hline Von Auwers and & {$[143]$} & Density \\
Fruhling & {$[144]$} & Vapor pressure \\
\hline $\begin{array}{l}\text { Wieczorek and } \\
\text { Kobayashi }\end{array}$ & {$[145,146]$} & Viscosity \\
\hline Yokoyama et al. & & \\
\hline
\end{tabular}

\section{Decahydro-2-methylnaphthalene}

\begin{tabular}{|l|r|l|}
\hline Author(s) & Reference & Topic \\
\hline Adkins and Davis & {$[147]$} & boiling point \\
\hline Gollis et al. & {$[87]$} & viscosity, thermal conductivity \\
\hline Gudzinowicz et al. & {$[148]$} & density, viscosity \\
\hline Weissenberger et al. & {$[149]$} & boiling point, density \\
\hline
\end{tabular}


Heptylcyclohexane

\begin{tabular}{|l|r|l|}
\hline Author(s) & Reference & Topic \\
\hline Baylaucq et al. & {$[150]$} & viscosity, density \\
\hline Luther & {$[151]$} & density \\
\hline Marsh et al. & {$[100]$} & heat capacity \\
\hline Mokbel et al. & {$[152]$} & vapor pressure \\
\hline Schlenk & {$[153]$} & boiling point \\
\hline Schmidt & {$[154]$} & freezing point \\
\hline Schmidt and Grosser & {$[155]$} & boiling point, viscosity \\
\hline
\end{tabular}

\section{Cis-decahydronaphthalene}

\begin{tabular}{|l|r|l|}
\hline Author(s) & Reference & Topic \\
\hline Allinger and Coke & {$[156]$} & boiling point \\
\hline Bird and Daly & {$[157]$} & viscosity \\
\hline Boord et al. & {$[158]$} & freezing point, boiling point, density \\
\hline Briggs & {$[116]$} & thermal conductivity \\
\hline Camin and Rossini & {$[118]$} & density, vapor pressure, surface tension \\
\hline Cheng et al. & {$[159]$} & boiling point, critical temperature \\
\hline Chylinksi and Stryjek & {$[160]$} & density \\
\hline Cooper et al. & {$[161]$} & boiling point \\
\hline Daubin et al. & {$[162]$} & boiling point, density \\
\hline Fenske et al. & {$[164]$} & density, vapor pressure \\
\hline Fischer and Weiss & {$[86]$} & viscosity \\
\hline Foehr and Fenske & {$[165]$} & boiling point, density \\
\hline Frezzotti et al. & {$[166]$} & thermal conductivity \\
\hline Glaser and Ruland & {$[123]$} & critical pressure, critical temperature \\
\hline Gudzinowicz et al. & {$[167]$} & density, thermal conductivity \\
\hline Guenthard et al. & {$[168]$} & density \\
\hline Hibbit and Linstead & {$[169]$} & boiling point, density \\
\hline Hogenboom et al. & {$[170]$} & viscosity, freezing point, density \\
\hline Huckel & {$[171]$} & boiling point, freezing point, density \\
\hline Huckel & {$[172]$} & density \\
\hline Huckel et al & {$[173]$} & density \\
\hline Ipatieff and Pines & {$[174]$} & boiling point \\
\hline Jasper & {$[175]$} & surface tension \\
\hline Korosi and Kovats & {$[176]$} & density, surface tension \\
\hline Kuss & density \\
\hline Lauer and King & density \\
\hline Lozovoi et al. & density \\
\hline Lyusternik and Zhdanov & viscosity \\
\hline Marsh et al. & heat capacity \\
\hline
\end{tabular}




\begin{tabular}{|l|r|l|}
\hline Author(s) & Reference & Topic \\
\hline McCullough et al. & {$[181]$} & triple point \\
\hline Nuzzi & {$[182]$} & viscosity \\
\hline Pak and Kay & {$[183]$} & critical pressure, critical temperature \\
\hline Parks and Hatton & {$[184]$} & freezing point \\
\hline Parthasarathy & {$[185]$} & density \\
\hline Petrov & {$[186]$} & freezing point \\
\hline Polenske and Eisenlohr & {$[163]$} & boiling point, density \\
\hline Prokopetz & {$[187]$} & boiling point, density \\
\hline Rank et al. & {$[188]$} & boiling point \\
\hline Ruzicka et al. & {$[189]$} & boiling point, density \\
\hline Schiessler et al. & {$[190]$} & viscosity \\
\hline Seyer and Barrow & {$[191]$} & freezing point, density \\
\hline Seyer and Leslie & {$[192]$} & viscosity, freezing point \\
\hline Seyer and Mann & {$[193]$} & freezing point, boiling point, vapor pressure \\
\hline Seyer and Walker & {$[194]$} & density, surface tension \\
\hline Shiohama et al & {$[195]$} & density \\
\hline Shiohama et al & {$[196]$} & density \\
\hline Sohda et al. & {$[197]$} & vapor pressure, surface tension \\
\hline Stokkum & {$[198]$} & viscosity \\
\hline Streiff et al. & {$[199]$} & freezing point \\
\hline Timmermans & {$[200]$} & freezing point \\
\hline Zeberg-Mikkelsen et al. & {$[201]$} & viscosity, density \\
\hline Zelinskii & {$[202]$} & density \\
\hline
\end{tabular}

\section{1- dodecene}

\begin{tabular}{|l|r|l|}
\hline Author(s) & Reference & Topic \\
\hline Asinger & {$[203]$} & density, boiling point \\
\hline Baumgarten & {$[204]$} & boiling point \\
\hline Boord et al. & {$[205]$} & density, boiling point, freezing point \\
\hline Engler and Hofer & {$[206]$} & density \\
\hline Evans & {$[122]$} & density, viscosity, boiling point \\
\hline Forziati et al. & {$[207]$} & density, vapor pressure, boiling point \\
\hline Geldof and Wibaut & {$[208]$} & boiling point \\
\hline Gude et al. & {$[209]$} & critical pressure, critical temperature \\
\hline Hunig and Kiesel & {$[210]$} & boiling point \\
\hline Jasper & {$[175]$} & surface tension \\
\hline Jasper and Kerr & {$[211]$} & surface tension \\
\hline Jasper and Kring & {$[212]$} & surface tension \\
\hline Jeffery and Vogel & {$[213]$} & density, boiling point \\
\hline Krafft & {$[214]$} & density, boiling point \\
\hline Krassilchik & {$[215]$} & density \\
\hline Labarre & {$[216]$} & density, boiling point \\
\hline
\end{tabular}




\begin{tabular}{|l|r|l|}
\hline Author(s) & Reference & Topic \\
\hline Lenneman et al. & {$[217]$} & boiling point \\
\hline Luther & {$[151]$} & density \\
\hline Lyusternik and Zhdanov & {$[180]$} & viscosity \\
\hline Maman & {$[218]$} & density \\
\hline Marsh et al. & {$[100]$} & heat capacity \\
\hline McCullough et al. & {$[219]$} & triple point \\
\hline $\begin{array}{l}\text { Mukhamedzyanov and } \\
\text { Usmanov }\end{array}$ & {$[220]$} & thermal conductivity \\
\hline Petrov et al. & {$[221]$} & density, boiling point \\
\hline Schiessler & {$[136]$} & viscosity \\
\hline Schiessler et al. & {$[190]$} & viscosity \\
\hline Schmidt & {$[154]$} & density, freezing point \\
\hline Schmidt et al. & {$[222]$} & density, boiling point, freezing point, viscosity \\
\hline Streiff et al. & {$[199]$} & freezing point \\
\hline Tilicheev et al. & {$[223]$} & density, boiling point \\
\hline Urry et al. & {$[224]$} & boiling point \\
\hline Wibaut and Geldof & {$[225]$} & density \\
\hline Zafiriadis and Mastagli & {$[226]$} & boiling point \\
\hline
\end{tabular}

\section{1-tridecene}

\begin{tabular}{|l|r|l|}
\hline Author(s) & Reference & Topic \\
\hline Camin and Rossini & {$[118]$} & density, vapor pressure \\
\hline Jasper & {$[175]$} & surface tension \\
\hline Kozacik and Reid & {$[227]$} & density \\
\hline Lagemann et al. & {$[228]$} & density \\
\hline Luther & {$[151]$} & density \\
\hline Marsh et al. & {$[100]$} & heat capacity \\
\hline Petrov et al. & {$[221]$} & density, boiling point \\
\hline Pictet and Potok & {$[229]$} & density, boiling point \\
\hline Scheissler & {$[230]$} & density \\
\hline Schiessler & {$[136]$} & viscosity \\
\hline Schiessler et al. & {$[190]$} & viscosity, density \\
\hline Schmidt & {$[222]$} & density, freezing point \\
\hline Schmidt et al. & {$[141]$} & freezing point \\
\hline Streiff et al. & {$[223]$} & density, boiling point \\
\hline Tilicheev et al. & &
\end{tabular}




\section{2,2-dimethylbutane}

\begin{tabular}{|l|r|l|}
\hline Author(s) & Reference & Topic \\
\hline Ambrose et al & {$[231]$} & critical temperature \\
\hline Aucejo et al. & {$[232]$} & density, viscosity \\
\hline Avery and Ellis & {$[233]$} & boiling point \\
\hline Bazhulin et al. & {$[234]$} & density, boiling point \\
\hline Bishop et al. & {$[235]$} & density, boiling point \\
\hline Boord & {$[236]$} & boiling point \\
\hline Brame and Hunter & {$[237]$} & density, boiling point \\
\hline Brazier and Freeman & {$[238]$} & viscosity, density \\
\hline Brewster et al. & {$[239]$} & boiling point \\
\hline Brooks et al. & {$[240]$} & density, boiling point, freezing point \\
\hline Chavanne and van & {$[241]$} & density, boiling point, viscosity \\
Risseghem & & \\
\hline Chavanne & {$[242]$} & density, boiling point \\
\hline Chen and Zwolinski & {$[243]$} & density, vapor pressure \\
\hline Compostizo et al. & {$[244]$} & density \\
\hline Cramer and Mulligan & {$[245]$} & density, boiling point \\
\hline Denyer et al. & {$[246]$} & density, boiling point, freezing point \\
\hline Derfer et al. & {$[247]$} & density, boiling point \\
\hline Desty and Whyman & {$[248]$} & boiling point \\
\hline Dixon & {$[249]$} & density \\
\hline Douslin and Huffman & {$[250]$} & triple point \\
\hline Eicher and Zwolinski & {$[251]$} & viscosity \\
\hline Felsing and Watson & {$[252]$} & density, boiling point \\
\hline Fenske et al. & {$[253]$} & boiling point \\
\hline Finke et al. & {$[254]$} & freezing point \\
\hline Fischer & {$[255]$} & melting point \\
\hline Foehr and Fenske & {$[165]$} & density, boiling point \\
\hline Fomin and Sochanski & {$[256]$} & density \\
\hline Forziati & {$[257]$} & density, boiling point, freezing point \\
\hline Forziati et al. & {$[258]$} & density \\
\hline Funk et al. & {$[259]$} & vapor pressure \\
\hline Genco et al. & {$[260]$} & critical volume, critical temperature, critical pressure \\
\hline Glasgow and Rossini & {$[261]$} & freezing point \\
\hline Glasgow et al. & {$[262]$} & freezing point \\
\hline Griskey and Canjar & {$[263]$} & vapor pressure \\
\hline Griswold et al. & {$[264]$} & boiling point \\
\hline Grummit et al. & {$[265]$} & density, boiling point \\
\hline Haensel and Ipatieff & {$[266]$} & boiling point \\
\hline Hickman & {$[267]$} & boiling point \\
\hline Hicks-Brunn et al. & {$[268]$} & density, triple point, boiling point \\
\hline Hoog et al. & {$[114]$} & density, boiling point, freezing point \\
\hline Howard et al. & & \\
\hline
\end{tabular}




\begin{tabular}{|c|c|c|}
\hline Author(s) & Reference & Topic \\
\hline Jasper & {$[175]$} & surface tension \\
\hline Kay & [270] & $\begin{array}{l}\text { vapor pressure, density, critical density, critical } \\
\text { temperature, boiling point }\end{array}$ \\
\hline Kay and Young & [271] & critical temperature, critical pressure \\
\hline Kilpatrick and Pitzer & {$[272]$} & vapor pressure, triple point \\
\hline Kimura and Benson & $\begin{array}{r}{[273,274,} \\
275]\end{array}$ & density \\
\hline Kishner & {$[276]$} & density, boiling point \\
\hline Kuss and Pollmann & [277] & viscosity \\
\hline Lambert et al. & [278] & viscosity \\
\hline Liberman et al. & [279] & density, boiling point \\
\hline Lichtenfels et al. & {$[280]$} & boiling point \\
\hline Maman & {$[281,282]$} & density, boiling point \\
\hline Mann et al. & [99] & density \\
\hline Marker and Oakwood & [283] & density, boiling point \\
\hline Markownikov & [284] & density, boiling point \\
\hline Marsh et al. & [100] & heat capacity \\
\hline McArdle and Robertson & [285] & density, boiling point \\
\hline $\begin{array}{l}\text { Moldavskii and } \\
\text { Nizovkina }\end{array}$ & [286] & density \\
\hline Nicolini and Laffitte & [287] & density, vapor pressure \\
\hline Noller & [288] & density, boiling point \\
\hline Oberfell and Frey & [289] & density, boiling point, freezing point \\
\hline Paz Andrade & [290] & density \\
\hline Pichler et al. & [291] & density, boiling point \\
\hline Rank et al. & [188] & boiling point \\
\hline Rodger et al. & [292] & density \\
\hline Sakiadis and Coates & [293] & thermal conductivity \\
\hline Sayegh and Ratcliff & [294] & vapor pressure \\
\hline Schmerling et al. & [295] & density, boiling point \\
\hline Serijan et al. & [296] & density \\
\hline Seubold & [297] & boiling point \\
\hline Shen and Williamson & [298] & density \\
\hline Smittenberg at al. & [299] & triple point, boiling point \\
\hline Smutny and Bondi & [300] & viscosity \\
\hline Stull & [301] & vapor pressure, boiling point, freezing point \\
\hline Timmermans & [302] & boiling point, freezing point \\
\hline Tooke and Aston & [303] & freezing point \\
\hline Treszczanowicz et al. & [304] & density \\
\hline Van Risseghem & [305] & density, freezing point \\
\hline Van Wijk and Versteeg & [306] & density, viscosity \\
\hline Vilim & [307] & thermal conductivity \\
\hline Waddington and Douslin & [308] & density \\
\hline Westerdijk et al. & [309] & density, boiling point \\
\hline
\end{tabular}




\begin{tabular}{|l|r|l|}
\hline Author(s) & Reference & Topic \\
\hline Wibaut and Gitsels & {$[310]$} & boiling point \\
\hline Wibaut et al. & {$[311]$} & density, boiling point, freezing point \\
\hline Willingham et al. & {$[312]$} & vapor pressure, boiling point \\
\hline Wojciechowski & {$[313]$} & boiling point, freezing point \\
\hline Young & {$[314]$} & critical temperature, critical pressure \\
\hline Zhang et al. & {$[315]$} & density \\
\hline
\end{tabular}

\section{n-hexadecane}

\begin{tabular}{|l|r|l|}
\hline Author(s) & Reference & Topic \\
\hline Ait-Kaci and Merlin & {$[316]$} & melting point \\
\hline Ambrose & {$[115]$} & critical temperature \\
\hline $\begin{array}{l}\text { Aminabhavi and } \\
\text { Gopalkrishma }\end{array}$ & {$[317]$} & density, viscosity \\
\hline Anselme et al. & {$[318]$} & critical temperature, critical density \\
\hline Aracil et al. & {$[319,320]$} & density \\
\hline Aralaguppi et al. & {$[321]$} & viscosity, density \\
\hline Arenosa et al. & {$[322]$} & density \\
\hline Asfour et al. & {$[323]$} & density \\
\hline Assael et al. & {$[232]$} & viscosity \\
\hline Aucejo et al. & {$[325]$} & viscosity, density \\
\hline Aucejo et al. & {$[326]$} & viscosity \\
\hline Awwad et al. & {$[327]$} & density \\
\hline Awwad and Allos & {$[328]$} & density \\
\hline Awwad and Pethwick & {$[331]$} & viscosity, density \\
\hline Awwad and Salman & {$[329,330]$} & denity \\
\hline Awwad et al. & {$[334]$} & density \\
\hline Awwad et al. & {$[336]$} & bonsity \\
\hline Banipal et al. & {$[337]$} & viscosity \\
\hline Banos et al. & {$[338]$} & density \\
\hline Barber and English & {$[339]$} & boiling point \\
\hline Behrends and Kaatze & {$[340]$} & density \\
\hline Benson and Handa & {$[341]$} & density \\
\hline Berger & {$[342]$} & thermal conductivity \\
\hline Bhattacharyya et al. & {$[158]$} & boiling point, melting point, density \\
\hline Boelhouwer & {$[343]$} & density \\
\hline Bogatov et al. & {$[345]$} & vapor pressure \\
\hline Boord et al. & density \\
\hline Bradley and Shellard & density \\
\hline Bridgman & vapor pressure, density \\
\hline Bronsted and Koefoed & & \\
\hline Calingaert et al. & \\
\hline Camin et al & {$[3337]$} & density \\
\hline
\end{tabular}




\begin{tabular}{|c|c|c|}
\hline Author(s) & Reference & Topic \\
\hline Carey and Smith & {$[348]$} & melting point \\
\hline Celda et al. & [349] & density \\
\hline Chang et al. & [350] & density \\
\hline Chawla et al. & [351] & density \\
\hline Chevalier et al. & {$[352]$} & viscosity, density \\
\hline Chylinski and Stryjek & [353] & viscosity \\
\hline Chylinski and Stryjek & [160] & density \\
\hline Cooper and Asfour & [354] & viscosity, density \\
\hline Coursey and Heric & [355] & viscosity, density \\
\hline Deanesly & [356] & density, melting point \\
\hline DeLorenzi et al. & [357] & density, viscosity \\
\hline Dernini et al. & [358] & density \\
\hline Diaz Pena and Menduina & [359] & density \\
\hline $\begin{array}{l}\text { Diaz Pena and Nunez } \\
\text { Delgado }\end{array}$ & [360] & density \\
\hline Diaz-Pena and Tardajos & [361] & density \\
\hline Dixon & [249] & density \\
\hline Drahowzal & [362] & melting point \\
\hline Ducooulombier et al. & [363] & viscosity \\
\hline Dymond and Harris & [364] & density \\
\hline Dymond and Young & [365] & viscosity, density \\
\hline Dymond et al. & [366] & viscosity, density \\
\hline Evans & [122] & viscosity, density \\
\hline Evans & [367] & melting point \\
\hline Fenby et al. & [368] & density \\
\hline $\begin{array}{l}\text { Ferhat-Hamida and } \\
\text { Philippe }\end{array}$ & [369] & density \\
\hline Fermeglia and Torriano & [370] & viscosity, density \\
\hline Findenegg & [371] & density, melting point \\
\hline Finke et al. & [372] & triple point \\
\hline Foehr and Fenske & [165] & density, melting point \\
\hline Fox et al. & [373] & surface tension \\
\hline Francis and Wood & [374] & boiling point, vapor pressure \\
\hline Gensler and Mahadevan & [375] & boiling point \\
\hline Glaser et al. & [376] & density \\
\hline Gollis et al. & [87] & thermal conductivity, melting point \\
\hline Gouel & [377] & viscosity, density \\
\hline Graaf et al. & [378] & density \\
\hline Granovskaya & [379] & vapor pressure \\
\hline Griot et al. & {$[380,381]$} & density \\
\hline Grolier et al. & [382] & density \\
\hline Heric and Brewer & [383] & density, viscosity \\
\hline Heric and Brewer & [384] & density \\
\hline Heric and Coursey & [385] & density \\
\hline
\end{tabular}




\begin{tabular}{|c|c|c|}
\hline Author(s) & Reference & Topic \\
\hline Holmes et al. & {$[386]$} & thermal conductivity \\
\hline Holzapfel et al. & $\begin{array}{r}{[387,388,} \\
389]\end{array}$ & density \\
\hline Ivanov et al. & [390] & boiling point \\
\hline Jasper & [175] & surface tension \\
\hline Jasper et al. & [391] & surface tension \\
\hline Kemula et al. & [392] & boiling point, melting point \\
\hline Klofutar et al. & [393] & density \\
\hline Korosi and Kovats & [176] & surface tension \\
\hline Krafft & [394] & melting point, boiling point, density \\
\hline Krafft & [395] & density, melting point \\
\hline Krafft & [396] & density, vapor pressure, melting point \\
\hline Lagerlof & [397] & boiling point \\
\hline Lainez and Rodrigo & [398] & density \\
\hline Lainez et al. & [399] & density \\
\hline Lal et al. & [400] & density, viscosity \\
\hline $\begin{array}{l}\text { Langedijk and } \\
\text { Smithuysen }\end{array}$ & [401] & density, melting point \\
\hline Larkin et al. & [402] & melting point \\
\hline Larsen et al. & [129] & boiling point, melting point \\
\hline Lauer and King & [178] & density \\
\hline Lee et al. & [403] & vapor pressure \\
\hline Lenoir and Hipkin & [404] & density \\
\hline Levene & [405] & boiling point \\
\hline Levene et al. & [406] & boiling point, melting point \\
\hline Lim and Williamson & [407] & density \\
\hline Luther & {$[151]$} & density \\
\hline Mabery & [408] & boiling point \\
\hline Mabery & [409] & boiling point, density \\
\hline Mansker et al. & [410] & density \\
\hline Marsh et al. & [100] & heat capacity \\
\hline Marsh and Organ & [411] & density \\
\hline Matsui and Arakawa & [412] & boiling point, melting point, density \\
\hline Matthews et al. & [413] & viscosity, density \\
\hline McKinney & [414] & boiling point \\
\hline $\begin{array}{l}\text { McMakin and Van } \\
\text { Winkle }\end{array}$ & [415] & density \\
\hline Messow et al. & [416] & density \\
\hline Mills and Fenton & [417] & vapor pressure \\
\hline Mogollon et al. & [418] & critical temperature \\
\hline Mukhamedzyanov et al. & [419] & thermal conductivity \\
\hline Mumford and Phillips & [420] & density, melting point, boiling point, viscosity \\
\hline Mustafaev & [421] & thermal conductivity \\
\hline Myers & [422] & vapor pressure \\
\hline
\end{tabular}




\begin{tabular}{|l|r|l|}
\hline Author(s) & Reference & Topic \\
\hline Myers and Clever & {$[423]$} & surface tension, density \\
\hline Myers and Fenske & {$[424]$} & vapor pressure \\
\hline $\begin{array}{l}\text { Nederbragt and } \\
\text { Boelhouwer }\end{array}$ & {$[425]$} & viscosity \\
\hline Nhaesi and Asfour & {$[426]$} & density, viscosity \\
\hline Oddo & {$[427]$} & boiling point, melting point \\
\hline Orwoll and Flory & {$[428]$} & melting point \\
\hline Parks et al. & {$[429]$} & vapor pressure, triple point \\
\hline Perez et al. & {$[430]$} & vapor pressure \\
\hline Petrov & {$[186]$} & melting point \\
\hline Petrov and Kaplan & {$[431]$} & boiling point, density \\
\hline Philippe and Delmas & {$[432]$} & density \\
\hline Pilcher & {$[433]$} & triple point \\
\hline Plebanski et al. & {$[434]$} & density \\
\hline Powell and Groot & {$[435]$} & thermal conductivity \\
\hline Prophete & {$[436]$} & melting point \\
\hline Queimada et al. & {$[437]$} & density, viscosity \\
\hline Ralston et al. & {$[438]$} & melting point \\
\hline Rasskazov et al. & {$[439]$} & viscosity \\
\hline Rastorguev and Keramidi & {$[440]$} & viscosity \\
\hline Ratkovics et al. & {$[441]$} & viscosity \\
\hline Richardson and Parks & {$[442]$} & density \\
\hline Rolo et al. & {$[443]$} & surface tension \\
\hline Rosenthal and Teja & {$[444]$} & critical pressure, critical temperature \\
\hline Sakiadis and Coates & {$[445]$} & thermal conductivity \\
\hline Sanin and Melent'eva & {$[446]$} & viscosity \\
\hline Schiessler & {$[136]$} & viscosity \\
\hline Schiessler et al. & {$[190]$} & vapor pressure, density \\
\hline Schiessler & {$[230]$} & melting point \\
\hline Seyer et al. & {$[447]$} & density \\
\hline Shen and Williamson & {$[298]$} & density \\
\hline Smith & {$[448]$} & melting point \\
\hline Smith et al. & {$[450]$} & critical temperature \\
\hline Snow et al. & {$[451]$} & melting point \\
\hline Snyder and Winnick & {$[452]$} & density \\
\hline Sondheimer and Amiel & {$[453]$} & boiling point, melting point \\
\hline Sorabji & {$[454]$} & boiling point, melting point \\
\hline Streiff et al. & {$[141]$} & melting point \\
\hline Suehnel et al. & {$[455]$} & density \\
\hline Tanaka et al. & & \\
\hline Tardajos et al. & l456] & viscosity, density \\
\hline Tarzimanov and & thermal conductivity \\
Mashirov & Teja and Rice & density \\
\hline
\end{tabular}




\begin{tabular}{|l|r|l|}
\hline Author(s) & Reference & Topic \\
\hline Teja et al. & {$[461]$} & critical temperature \\
\hline Terhoff & {$[462]$} & density \\
\hline $\begin{array}{l}\text { Tilicheev and } \\
\text { Kachmarchik }\end{array}$ & {$[463]$} & melting point, density \\
\hline $\begin{array}{l}\text { Tilicheev and } \\
\text { Kachmarchik }\end{array}$ & {$[464]$} & density \\
\hline Tilicheev et al. & {$[465]$} & boiling point, melting point, density \\
\hline Trejo & {$[466]$} & density \\
\hline Treszczanowicz et al. & {$[467]$} & density \\
\hline Treszczanowicz et al. & {$[468]$} & density \\
\hline Tuot and Guyard & {$[469]$} & boiling point, density \\
\hline Ubbelohde & {$[470]$} & vapor pressure, melting point \\
\hline Van Hook and Silver & {$[471]$} & density, melting point \\
\hline Vavanellos et al. & {$[472]$} & viscosity \\
\hline Vogel & {$[473]$} & boiling point, melting point, density \\
\hline Wada et al. & {$[474]$} & thermal conductivity \\
\hline Wakefield & {$[475]$} & viscosity, density \\
\hline Wakefield and Marsh & {$[476]$} & viscosity, density \\
\hline Wang et al. & {$[477]$} & density \\
\hline Waterman et al. & {$[478]$} & boiling point, melting point, density \\
\hline Whitmore et al. & {$[479]$} & viscosity \\
\hline Wibaut et al. & {$[311]$} & density \\
\hline Wilhelm et al. & {$[480,481]$} & density \\
\hline Witek et al. & {$[482]$} & density \\
\hline Wu et al. & {$[483]$} & viscosity \\
\hline Young & {$[484]$} & boiling point, vapor pressure \\
\hline Zeinalov and Leikakh & {$[485]$} & density \\
\hline Ziegler et al. & {$[486]$} & boiling point, melting point \\
\hline
\end{tabular}

\section{n-dodecane}

\begin{tabular}{|l|r|l|}
\hline Author(s) & Reference & Topic \\
\hline Aicart et al. & {$[487]$} & density \\
\hline Allemand et al. & {$[488,489]$} & vapor pressure \\
\hline Ambrose and Townsend & {$[490]$} & critical pressure \\
\hline Ambrose et al. & {$[231]$} & critical temperature \\
\hline Aminabhavi and Banerjee & {$[491]$} & viscosity \\
\hline $\begin{array}{l}\text { Aminabhavi and } \\
\text { Gopalkrishma }\end{array}$ & {$[317]$} & viscosity, density \\
\hline Aminabhavi and Patil & {$[492]$} & viscosity, density \\
\hline Anselme et al. & {$[318]$} & critical density, critical temperature \\
\hline Aralaguppi et al. & {$[321493]$} & viscosity, density \\
\hline Arenosa et al. & {$[322]$} & density \\
\hline
\end{tabular}




\begin{tabular}{|l|r|l|}
\hline Author(s) & Reference & Topic \\
\hline Asfour et al. & {$[323]$} & density \\
\hline Aucejo et al. & {$[494,495]$} & density \\
\hline Aucejo et al. & {$[496]$} & viscosity \\
\hline Aucejo et al. & {$[232]$} & viscosity, density \\
\hline Awwad and Salman & {$[329]$} & viscosity, density \\
\hline Awwad et al. & {$[331]$} & viscosity \\
\hline Awwad and Allos & {$[497]$} & viscosity, density \\
\hline Awwad et al. & {$[331,332]$} & density \\
\hline Beale and Docksey & {$[498]$} & critical pressure, critical temperature, boiling point \\
\hline Benson et al. & {$[499]$} & density \\
\hline Berger & {$[339]$} & boiling point \\
\hline Bessieres, D. et al. & {$[500]$} & \\
\hline Bhattacharyya et al. & {$[340]$} & density \\
\hline Bidlack and Anderson & {$[501]$} & viscosity \\
\hline Bingham and Fornwalt & {$[502]$} & density, viscosity \\
\hline Boelhouwer & {$[341]$} & density \\
\hline Boord et al. & {$[158]$} & boiling point, density, freezing point \\
\hline Bridgman & {$[344]$} & vapor pressure \\
\hline Burgdorf et al. & {$[503]$} & viscosity, thermal conductivity, density \\
\hline Campbell et al. & {$[504]$} & boiling point \\
\hline Caudwell et al. & {$[505]$} & viscosity, density \\
\hline Celda et al. & {$[349]$} & density \\
\hline Celda et al. & {$[506]$} & viscosity \\
\hline Chawla et al. & {$[351]$} & density \\
\hline Chevalier et al. & {$[352]$} & viscosity, density \\
\hline Cooper et al. & {$[161]$} & boiling point \\
\hline Cooper and Asfour & {$[354]$} & viscosity, density \\
\hline Crawford and Harbourn & {$[507]$} & freezing point \\
\hline Cutler & {$[508]$} & density \\
\hline Cutler et al. & {$[509]$} & density, viscosity \\
\hline De Lorenzi et al. & {$[357]$} & viscosity, density \\
\hline Deanesly and Carleton & {$[356]$} & density, freezing point \\
\hline Dejoz et al. & {$[510]$} & density, boiling point, vapor pressure \\
\hline DeLorenzi et al. & {$[357]$} & density \\
\hline Dernini et al. & {$[358]$} & density \\
\hline Diaz Pena and Menduina & {$[359]$} & density \\
\hline Diaz Pena and Nunez & {$[360]$} & density \\
Delgado & {$[361]$} & density \\
\hline Diaz Pena and Tardajos & {$[249]$} & density \\
\hline Dixon & {$[512]$} & density \\
\hline Dornte and Smyth & viscosity \\
\hline Drabek and Cibulka & viscosity \\
\hline Ducoulombier et al. & \\
\hline Dymond et al. & & \\
\hline
\end{tabular}




\begin{tabular}{|c|c|c|}
\hline Author(s) & Reference & Topic \\
\hline Dymond et al. & [513] & viscosity, density \\
\hline Dymond et al. & {$[514,515]$} & density \\
\hline Evans & [367] & viscosity, density, boiling point \\
\hline Fenske et al. & [253] & boiling point \\
\hline $\begin{array}{l}\text { Ferhat-Hamida and } \\
\text { Philippe }\end{array}$ & [369] & density \\
\hline Findenegg & [371] & density \\
\hline Finke et al. & [372] & triple point \\
\hline Francis & [516] & critical temperature, density \\
\hline Garcia et al. & [517] & viscosity \\
\hline Gensler et al. & [518] & boiling point \\
\hline Gierycz et al. & [519] & vapor pressure \\
\hline Giller and Drickamer & [520] & viscosity, freezing point \\
\hline Gollis et al. & [87] & thermal conductivity, freezing point \\
\hline Gomez-Ibanez and Liu & [521] & boiling point, density \\
\hline Gonzalez et al. & [522] & viscosity, density \\
\hline Gouel & [377] & viscosity \\
\hline Gouel & [523] & density \\
\hline Grigg et al. & [524] & density \\
\hline Griot et al. & [381] & density \\
\hline Grolier and Benson & [525] & density \\
\hline Grolier et al. & [382] & density \\
\hline Guieu et al. & [526] & freezing point \\
\hline Hamam et al. & [527] & density \\
\hline Hansen and Hansen & [528] & boiling point \\
\hline Hogenboom et al. & [529] & viscosity, freezing point \\
\hline Horie and Morikawa & [530] & density, boiling point, freezing point \\
\hline Houser and McLean & [531] & density, vapor pressure \\
\hline Huffman et al. & [127] & triple point \\
\hline Iwahashi et al. & [532] & viscosity \\
\hline Jasper et al. & [391] & surface tension \\
\hline Jessup and Stanley & [533] & boiling point, density, freezing point \\
\hline Jobst & [534] & thermal conductivity \\
\hline Kashiwagi and Makita & [535] & viscosity \\
\hline Kashiwagi et al. & [536] & thermal conductivity \\
\hline Keistler and Andrews & [537] & density, vapor pressure \\
\hline Keramidi and Rastorguev & [538] & viscosity \\
\hline Kharasch et al. & [539] & boiling point \\
\hline Kincannon and Manning & [540] & boiling point, density \\
\hline Knapstad et al. & [541] & viscosity \\
\hline Knapstad et al. & [542] & viscosity, density \\
\hline Korosi and Kovats & [176] & surface tension \\
\hline Krafft & [396] & density, freezing point, vapor pressure \\
\hline Kurtyka and Kurtyka & [543] & boiling point \\
\hline
\end{tabular}




\begin{tabular}{|l|r|l|}
\hline Author(s) & Reference & Topic \\
\hline Lainez et al. & {$[399]$} & density \\
\hline Landau and Wuerflinger & {$[544]$} & density \\
\hline Leslie and Heuer & {$[545]$} & freezing point \\
\hline Luther & {$[151]$} & density \\
\hline Lyusternik and Zhdanov & {$[180]$} & viscosity \\
\hline Lyvers and Belyanina & {$[546]$} & density \\
\hline Mair & {$[547]$} & freezing point \\
\hline Mair and Streiff & {$[131]$} & density, boiling point, freezing point \\
\hline Mallan et al. & {$[548]$} & thermal conductivity \\
\hline Maman & {$[218]$} & boiling point, density \\
\hline Mansker et al. & {$[410]$} & density \\
\hline Marsh et al. & {$[100]$} & heat capacity \\
\hline Mears et al. & {$[549]$} & boiling point, freezing point, density \\
\hline Messow et al. & {$[416]$} & density \\
\hline Mogollon et al. & {$[418]$} & critical temperature \\
\hline Moreiras et al. & {$[550]$} & viscosity, density \\
\hline Morse & {$[551]$} & boiling point \\
\hline Mukhamedzyanov et al. & {$[552]$} & thermal conductivity \\
\hline Mustafaev & {$[553]$} & thermal conductivity \\
\hline Nayak et al. & {$[554]$} & viscosity, density \\
\hline Neruchev et al. & {$[555]$} & density, boiling point \\
\hline Ortega et al. & {$[556$,} & density \\
\hline Ott and Goates & $558]$ & \\
\hline Pak and Kay & {$[559]$} & freezing point \\
\hline Parks and Huffman & {$[560]$} & critical pressure, critical temperature \\
\hline Petrov and Kaplan & {$[133]$} & freezing point \\
\hline Philippe and Delmas & {$[431]$} & density, boiling point \\
\hline Powell and Groot & {$[432]$} & density \\
\hline Quayle et al. & {$[435]$} & thermal conductivity \\
\hline Ralston et al. & {$[561]$} & density, boiling point \\
\hline Rosenthal and Teja & {$[438]$} & freezing point \\
\hline Sahgal and Hayduk & {$[544]$} & critical pressure, critical temperature \\
\hline Sakiadis and Coates & {$[445]$} & density \\
\hline Schiessler & {$[230]$} & freezing point, vapor pressure \\
\hline Schiessler et al. & {$[190]$} & density \\
\hline Schmidt et al. & {$[563]$} & density, surface tension \\
\hline Seyer & {$[564]$} & freezing point \\
\hline Shen and Williamson & {$[298]$} & density \\
\hline Shen et al. & {$[566]$} & density \\
\hline Shepard et al. & density, freezing point, viscosity, boiling point \\
\hline Smith & lititical temperature \\
\hline Smith et al. & density \\
\hline Snyder and Winnick & & \\
\hline
\end{tabular}




\begin{tabular}{|l|r|l|}
\hline Author(s) & Reference & Topic \\
\hline Sondheimer and Amiel & {$[453]$} & boiling point \\
\hline Sondheimer et al. & {$[568]$} & freezing point \\
\hline Streiff et al. & {$[141]$} & freezing point \\
\hline Suri & {$[569]$} & density \\
\hline Takagi and Teranishi & {$[570]$} & density \\
\hline Tanaka & {$[456]$} & viscosity, density \\
\hline Tanaka et al. & {$[571]$} & thermal conductivity \\
\hline Tardajos et al. & {$[457,458]$} & density \\
\hline Teja et al. & {$[461]$} & critical temperature \\
\hline Terhoff & {$[462]$} & density \\
\hline Tilicheev et al. & {$[223]$} & boiling point, freezing point \\
\hline Tilicheev et al. & {$[465]$} & density \\
\hline Timmermans & {$[572]$} & freezing point \\
\hline Trejo & {$[466]$} & density \\
\hline Trenzado et al. & {$[573]$} & viscosity, density \\
\hline Treszczanowicz and Lu & {$[574]$} & vapor pressure \\
\hline Treszczanowicz et al. & {$[468,575]$} & density \\
\hline Tsimering and Kertes & {$[576]$} & density \\
\hline Vogel & {$[473]$} & boiling point, density \\
\hline Vogel and Schuberth & {$[577]$} & density \\
\hline Wakefield and Marsh & {$[476]$} & viscosity \\
\hline Wakefield & {$[475]$} & viscosity, density \\
\hline Wang et al. & {$[477,578]$} & density \\
\hline Weissler and Del Grosso & {$[579]$} & density \\
\hline Wilhelm et al. & {$[480,481]$} & density \\
\hline Willingham et al. & {$[312]$} & vapor pressure \\
\hline Witek et al. & {$[482]$} & density \\
\hline Wu et al. & {$[483]$} & viscosity \\
\hline Yanes et al. & {$[580]$} & density \\
\hline Young & {$[484]$} & vapor pressure, boiling point \\
\hline Ziegler et al. & {$[486]$} & boiling point, freezing point \\
\hline Zook and Goldey & $581]$ & boiling point \\
\hline & & \\
\hline
\end{tabular}


Table 2. Surrogate mixture formulation.

\begin{tabular}{|l|l|l|l|c|}
\hline Fluid & CAS \# & Formula & MW & Mole\% \\
\hline 3-ethyl-4,4-dimethyl-2-pentene & $53907-59-8$ & C9H18 & 126.24 & 9.98 \\
\hline Cyclodecene & $3618-12-0$ & C10H18 & 138.25 & 2.11 \\
\hline 2-methylnonane & $871-83-0$ & C10H22 & 142.28 & 2.32 \\
\hline 2-methylnaphthalene & $91-57-6$ & C11H10 & 142.20 & 5.10 \\
\hline 2-methyldecalin & $2958-76-1$ & C11H20 & 152.28 & 22.35 \\
\hline 3-methyldecane & $13151-34-3$ & C11H24 & 156.31 & 10.84 \\
\hline 1-dodecene & $112-41-4$ & C12H24 & 168.32 & 2.64 \\
\hline Cyclododecane & $294-62-2$ & C12H24 & 168.32 & 4.27 \\
\hline 4-methyl-4-undecene & $61142-40-3$ & C12H24 & 168.32 & 10.45 \\
\hline n-dodecane & $112-40-3$ & C12H26 & 170.33 & 1.93 \\
\hline Heptylcyclohexane & $5617-41-4$ & C13H26 & 182.35 & 14.22 \\
\hline 1-tridecene & $2437-56-1$ & C13H26 & 182.35 & 1.45 \\
\hline 2,7,10-trimethyldodecane & $74645-98-0$ & C15H32 & 212.41 & 10.38 \\
\hline n-hexadecane & $544-76-3$ & C16H34 & 226.44 & 1.95 \\
\hline & & & & $\Sigma=99.99 \%$
\end{tabular}




\section{Chemical Characterization}

Rocket propellant RP-1 is a kerosene, a complex hydrocarbon mixture that may be thermally unstable at temperatures above $600 \mathrm{~K}$. Thus, it was critical to the success of this project to characterize the components in RP-1, both before and after experimental properties studies. A discussion of the procedures, interpretation of results and identification of components are provided in Appendix B. Tables 3 to 7 provide the results of the chemical characterization of the RP-1 sample. 
Table 3. Tier 1 - Identification of constituents of $2 \%$ (mass/mass) or higher. These constituents represent $59 \%$ of the total mass in the sample.

\begin{tabular}{|c|c|c|c|c|c|c|c|c|}
\hline Peak & $\begin{array}{l}\text { Retention } \\
\text { time, min }\end{array}$ & Profile & $\begin{array}{l}\text { Corr. } \\
\text { coef. }\end{array}$ & Conf. & Name & CAS Reg. No. & RMM & $\%$ \\
\hline 1 & 4.480 & $\mathrm{~S}$ & 50 & $\mathrm{M}$ & $\begin{array}{l}\text { 2,2-dimethyl- } \\
\text { butane }\end{array}$ & $000075-83-2$ & 86.11 & 2.375 \\
\hline 2 & 4.619 & A & 64 & $\mathrm{H}$ & $\begin{array}{l}\text { 3-methyl- } \\
\text { decane }\end{array}$ & 013151-34-3 & 156.19 & 3.985 \\
\hline 3 & 5.117 & A & 43 & M & $\begin{array}{l}\text { 3-ethyl-4,4- } \\
\text { dimethyl-2- } \\
\text { pentene }\end{array}$ & 053907-59-8 & 126.14 & 2.726 \\
\hline 4 & 5.486 & A & 47 & $\mathrm{M}$ & $\begin{array}{l}\text { 2,9-dimethyl- } \\
\text { decane }\end{array}$ & 001002-17-1 & 170.2 & 6.280 \\
\hline 5 & 5.808 & $\mathrm{~S}$ & 94 & $\mathrm{H}$ & $\begin{array}{l}\text { 2-methyl-cis- } \\
\text { decalin }\end{array}$ & $1000152-47-3$ & 152.16 & 3.970 \\
\hline 6 & 6.008 & A & 98 & $\mathrm{H}$ & $\begin{array}{l}\text { decahydro-2- } \\
\text { methyl } \\
\text { naphthalene }\end{array}$ & 002958-76-1 & 152.16 & 2.574 \\
\hline 7 & 6.307 & $\mathrm{~S}$ & 50 & $\mathrm{M}$ & $\begin{array}{l}\text { cis-syn-1- } \\
\text { methyl- } \\
\text { decalin }\end{array}$ & 1000158-89-1 & 152.16 & 4.652 \\
\hline $8 \mathrm{a}^{\dagger}$ & $\begin{array}{l}6.468 \\
6.537 \\
6.653\end{array}$ & $\begin{array}{l}\text { S } \\
\text { A } \\
\text { S }\end{array}$ & 43 & M & $\begin{array}{l}\text { 1-hexyl-3- } \\
\text { methylcyclo } \\
\text { pentane } \\
\text { cyclo } \\
\text { dodecane }\end{array}$ & $000294-62-2$ & 168.19 & 5.099 \\
\hline 9 & 7.443 & $\mathrm{~S}$ & 43 & M & 1-dodecene & 000112-41-4 & 168.19 & 5.995 \\
\hline 10 & 7.789 & $\mathrm{~S}$ & 78 & $\mathrm{H}$ & $\begin{array}{l}\text { 2-methyl- } \\
\text { undecane }\end{array}$ & $007045-71-8$ & 170.2 & 3.124 \\
\hline 11 & 7.996 & $\mathrm{~S}$ & 59 & $\mathrm{M}$ & $\begin{array}{l}\text { 3-methyl- } \\
\text { undecane }\end{array}$ & $001002-43-3$ & 170.2 & 2.839 \\
\hline 12 & 8.150 & A & 56 & $\mathrm{M}$ & $\begin{array}{l}\text { 2,2-dimethyl- } \\
\text { decadi-3,5- } \\
\text { ene }\end{array}$ & 055638-50-1 & 166.17 & 2.735 \\
\hline 13 & 8.464 & $\mathrm{~S}$ & NA & $\mathrm{M}$ & $\begin{array}{l}\text { methylcyclo- } \\
\text { dodecane }\end{array}$ & NA & 182.22 & 3.580 \\
\hline 14 & 9.194 & $\mathrm{~S}$ & 90 & $\mathrm{H}$ & dodecane & $000112-40-3$ & 170.20 & 5.327 \\
\hline 15 & 9.746 & $\mathrm{~S}$ & 50 & $\mathrm{M}$ & $\begin{array}{l}2,7,10- \\
\text { trimethyl- } \\
\text { dodecane }\end{array}$ & 074645-98-0 & 212.25 & 3.765 \\
\hline
\end{tabular}

${ }^{\dagger}$ This peak consists of two coeluting solutes. 
Table 4. Tier 2 - Identification of constituents of $1 \%$ (mass/mass) or higher. These constituents represent $18.7 \%$ of the total mass of the sample.

\begin{tabular}{|c|c|c|c|c|c|c|c|c|}
\hline Peak & $\begin{array}{l}\text { Retention } \\
\text { time, min }\end{array}$ & Profile & $\begin{array}{l}\text { Corr. } \\
\text { coef. }\end{array}$ & Conf. & Name & CAS Reg. No. & RMM & $\%$ \\
\hline $\mathrm{a}$ & 3.144 & A & 50 & M & $\begin{array}{l}\text { 2,7-di- } \\
\text { methyl octane } \\
\text { or } \\
\text { 2-methyl } \\
\text { nonane }\end{array}$ & $\begin{array}{l}001072-16-8 \\
000871-83-0\end{array}$ & $\begin{array}{l}142.17 \\
142.17\end{array}$ & 1.329 \\
\hline $\mathrm{b}$ & 4.303 & $\mathrm{~S}$ & 89 & $\mathrm{H}$ & cyclodecene & $003717-12-0$ & 138.14 & 1.610 \\
\hline $\mathrm{c}$ & 4.373 & A & 50 & $\mathrm{U}$ & $\begin{array}{l}\text { cis-deca- } \\
\text { hydro } \\
\text { naphthalene }\end{array}$ & $108746-01-6$ & 138.14 & 1.174 \\
\hline $\mathrm{d}$ & 6.944 & A & 14 & $\mathrm{M}$ & $\begin{array}{l}\mathrm{z}-1,9- \\
\text { dodeca- } \\
\text { diene }\end{array}$ & $1000245-71-0$ & 166.17 & 1.754 \\
\hline $\mathrm{e}$ & 7.075 & $\mathrm{~S}$ & 15 & $\mathrm{M}$ & $\begin{array}{l}\text { 4-methyl-4- } \\
\text { uncecene }\end{array}$ & $061142-40-3$ & 168.19 & 1.663 \\
\hline$f$ & 9.846 & $\mathrm{~S}$ & 20 & $\mathrm{M}$ & $x$-tridecene ${ }^{\dagger}$ & NA & 182.2 & 1.115 \\
\hline $\mathrm{g}$ & 10.230 & A & 30 & $\mathrm{M}$ & 1-tridecene & $111270-56-1$ & 182.2 & 1.241 \\
\hline $\mathrm{h}$ & 10.514 & $\mathrm{~S}$ & 72 & $\mathrm{H}$ & $\begin{array}{l}\text { heptylcyclo- } \\
\text { hexane }\end{array}$ & 005617-41-4 & 168.19 & 1.429 \\
\hline i & 10.698 & $\mathrm{~S}$ & 43 & M & $\mathrm{x}$-tridecene & NA & 182.2 & 1.305 \\
\hline j & 11.359 & A & 45 & $\mathrm{M}$ & $\mathrm{x}$-tridecene & NA & 182.2 & 1.977 \\
\hline $\mathrm{k}$ & 11.881 & $\mathrm{~S}$ & 58 & M & $\begin{array}{l}2,10 \text {-di- } \\
\text { methyl } \\
\text { undecane }\end{array}$ & 017301-27-8 & 184.22 & 1.507 \\
\hline 1 & 12.349 & A & NA & $\mathrm{M}$ & $\begin{array}{l}\mathrm{x} \text {-methyl } \\
\text { tridecane }\end{array}$ & NA & 197.2 & 1.494 \\
\hline $\mathrm{m}$ & 12.787 & $\mathrm{~S}$ & 94 & $\mathrm{H}$ & $\begin{array}{l}\text { 2-methyl } \\
\text { naphthalene }\end{array}$ & 000091-57-6 & 142.08 & 1.249 \\
\hline aa & 13.623 & $\mathrm{~S}$ & 97 & $\mathrm{H}$ & tridecane & $000629-50-5$ & 184.22 & 1.080 \\
\hline
\end{tabular}

${ }^{\dagger} \mathrm{x}$ signifies uncertainty in the location of the double bond or the methyl group. 
Table 5. Light fraction-identification of constituents of lightest components. These components represent $1.7 \%$ of the total mass of the sample.

\begin{tabular}{|l|l|l|l|l|l|l|l|l|}
\hline Peak & $\begin{array}{l}\text { Retention } \\
\text { time, min }\end{array}$ & Profile & $\begin{array}{l}\text { Corr. } \\
\text { coef. }\end{array}$ & Conf. & Name & CAS Reg. No. & RMM & $\%$ \\
\hline laa & 0.795 & $\mathrm{~A}$ & 2 & $\mathrm{M}$ & methane & $107902-82-8$ & 16.03 & trace \\
\hline la & 1.924 & $\mathrm{~A}$ & 50 & $\mathrm{H}$ & nonane & $000111-84-2$ & 128.16 & 0.179 \\
\hline lb & 2.615 & $\mathrm{~A}$ & 90 & $\mathrm{H}$ & $\begin{array}{l}\text { 1,3,5-trimethyl- } \\
\text { cyclohexane }\end{array}$ & $001795-26-2$ & 126.14 & 0.654 \\
\hline 1d & 3.551 & $\mathrm{~A}$ & 52 & $\mathrm{H}$ & 2-methyldecane & $006975-98-0$ & 156.19 & 0.817 \\
\hline
\end{tabular}

Table 6. Heavy fraction-identification of constituents of heaviest components. These constituents are not tabulated for mass percent.

\begin{tabular}{|c|c|c|c|c|c|c|c|c|}
\hline Peak & $\begin{array}{l}\text { Retention } \\
\text { time, min }\end{array}$ & Profile & $\begin{array}{l}\text { Corr. } \\
\text { coef. }\end{array}$ & Conf. & Name & CAS Reg. No. & RMM & $\%$ \\
\hline ha & 21.776 & $\mathrm{~S}$ & 30 & $\mathrm{M}$ & 5-methyl-2-undecene & 056851-34-4 & 168.19 & \\
\hline $\mathrm{hb}$ & 22.010 & A & 86 & $\mathrm{H}$ & $\begin{array}{l}\text { 2,6,10-trimethyl- } \\
\text { dodecene }^{\dagger}\end{array}$ & NA & 210.25 & \\
\hline he & 22.433 & A & $\begin{array}{l}59 \\
47\end{array}$ & U & $\begin{array}{l}\text { 3-methyl tridecane } \\
\text { or } \\
\text { tetradecane }\end{array}$ & $\begin{array}{l}006418-41-3 \\
\text { or } \\
000629-59-4\end{array}$ & $\begin{array}{l}198.24 \\
198.24\end{array}$ & \\
\hline hd & 24.083 & A & $\begin{array}{l}43 \\
22\end{array}$ & U & $\begin{array}{l}\text { hexadecane, } \\
\text { or } \\
\text { 1-tetradecene }\end{array}$ & $\begin{array}{l}000544-76-3 \\
\text { or } \\
001120-36-1\end{array}$ & $\begin{array}{l}226.27 \\
196.22\end{array}$ & \\
\hline
\end{tabular}

${ }^{\dagger}$ The location of double bond is not clear.

Table 7. Thermal decomposition kinetics measurements on RP-1.

\begin{tabular}{ccc}
\hline $\begin{array}{c}\text { Temperature } \\
\left({ }^{\circ} \mathrm{C}\right)\end{array}$ & $k \pm 1 \sigma$ & $\begin{array}{c}\mathrm{t}_{1 / 2} \\
(\mathrm{~min})\end{array}$ \\
\hline 375 & $(6.92 \pm 0.75) \times 10^{-5}$ & 167 \\
400 & $(2.00 \pm 0.23) \times 10^{-4}$ & 58 \\
425 & $(3.85 \pm 0.53) \times 10^{-4}$ & 30 \\
500 & $(1.07 \pm 0.17) \times 10^{-3}$ & 11
\end{tabular}




\section{Density}

\subsection{Density at Atmospheric Pressure}

The density of RP-1 was measured with an Archimedes (buoyancy) technique over the temperature range 1 to $43{ }^{\circ} \mathrm{C}$ under a nitrogen blanket at the prevailing atmospheric pressure (approximately $83 \mathrm{kPa}$ ). These measurements provide a direct determination of the density. They were conducted to provide a consistency check on the wide-ranging measurements made at Azerbaijan State Oil Academy and to investigate the potential batch-to-batch variation in this property.

The core of the experimental apparatus consists of a cylindrical aluminum "sinker" ( $m=$ $11.54077 \pm 0.00010 \mathrm{~g} ; V=4.2735 \pm 0.0013 \mathrm{~cm}^{3}$ ) that is housed in a test cell containing the fluid of interest. This sinker is suspended from a balance, and the experiment consists of weighing the (sinker + suspension device) and the suspension device alone (to give the "tare" weight). The density is given by

$$
\rho=\frac{m_{\text {sinker }}-\left(W_{\text {sinker }}-W_{\text {tare }}\right)}{V_{\text {sinker }}},
$$

where $W_{\text {sinker }}$ and $W_{\text {tare }}$ are the balance readings, and $m_{\text {sinker }}$ and $V_{\text {sinker }}$ are the mass and volume of the sinker. The volume of the sinker is adjusted for temperature from literature values for the thermal expansion of aluminum. Each density determination comprises multiple tare and sinker weighings, and the balance is calibrated before each determination by use of a small brass calibration mass placed on an auxiliary pan located above the test cell. The total uncertainty in the density is estimated to be $\pm 0.10 \%(\mathrm{k}=2)$. 
Temperature is controlled by an external bath circulating a propylene gycol mixture through channels in a copper shield surrounding the test cell. The temperature of the fluid is measured with a standard platinum resistance thermometer located in a thermowell in the test cell; its resistance is read with a nanovolt-level multimeter. The uncertainty in the temperature is $\pm 0.010{ }^{\circ} \mathrm{C}$. The standard deviation in the temperature over the 20 minutes needed to complete a single density determination averaged $0.004{ }^{\circ} \mathrm{C}$. The atmospheric pressure was read with a vibrating quartz crystal type pressure transducer with an uncertainty of $\pm 0.07 \mathrm{kPa}$.

The results are presented in Table 8 and Figure 1(a) for the original sample of RP-1. Three repetitions were carried out at each temperature. The sample was held statically in the cell a total of 10 days, and repeats of the $25{ }^{\circ} \mathrm{C}$ point taken nine days apart exhibited variations less than $0.15 \%$ in density. This provides an indication that the sample did not undergo any gross degradation or fractionation during the tests. These data have been correlated by a second-order polynomial (given in the figure) to facilitate comparisons.

Results for the ultra-low sulfur sample of RP-1 are given in Table 9. The percentage differences in density compared to the original RP-1 sample are shown in Figure 1(b) (where the baseline is the polynomial fit of the densities of the original sample). The differences between the two samples are seen to average $0.28 \%$, with the ultra-low sulfur sample having the higher densities. 
Table 8. Experimental densities for RP-1 (original sample) under nitrogen.

\begin{tabular}{rcc}
\hline Temperature, ${ }^{\circ} \mathrm{C}$ & Pressure, $\mathrm{kPa}$ & Density, $\mathrm{kg} / \mathrm{m}^{3}$ \\
& & \\
\hline 2.902 & 83.59 & 813.18 \\
2.899 & 83.59 & 813.30 \\
2.892 & 83.59 & 813.28 \\
23.283 & 83.72 & 799.01 \\
23.319 & 83.69 & 799.09 \\
23.355 & 83.67 & 799.01 \\
25.066 & 83.07 & 798.71 \\
25.072 & 83.10 & 797.58 \\
25.083 & 83.10 & 797.66 \\
43.115 & 83.07 & 785.01 \\
43.109 & 83.10 & 784.96 \\
43.050 & 83.10 & 785.09 \\
\hline
\end{tabular}

Table 9. Experimental densities for RP-1 (ultra-low sulfur) under nitrogen.

\begin{tabular}{ccc}
\hline Temperature, ${ }^{\circ} \mathrm{C}$ & Pressure, $\mathrm{kPa}$ & Density, $\mathrm{kg} / \mathrm{m}^{3}$ \\
& & \\
\hline 1.081 & 82.13 & 816.71 \\
1.091 & 82.12 & 816.70 \\
1.106 & 82.10 & 816.60 \\
23.941 & 82.61 & 800.88 \\
23.911 & 82.61 & 800.91 \\
23.878 & 82.63 & 801.15 \\
39.693 & 82.25 & 790.01 \\
39.705 & 82.23 & 789.79 \\
39.720 & 82.25 & 789.68 \\
\hline
\end{tabular}



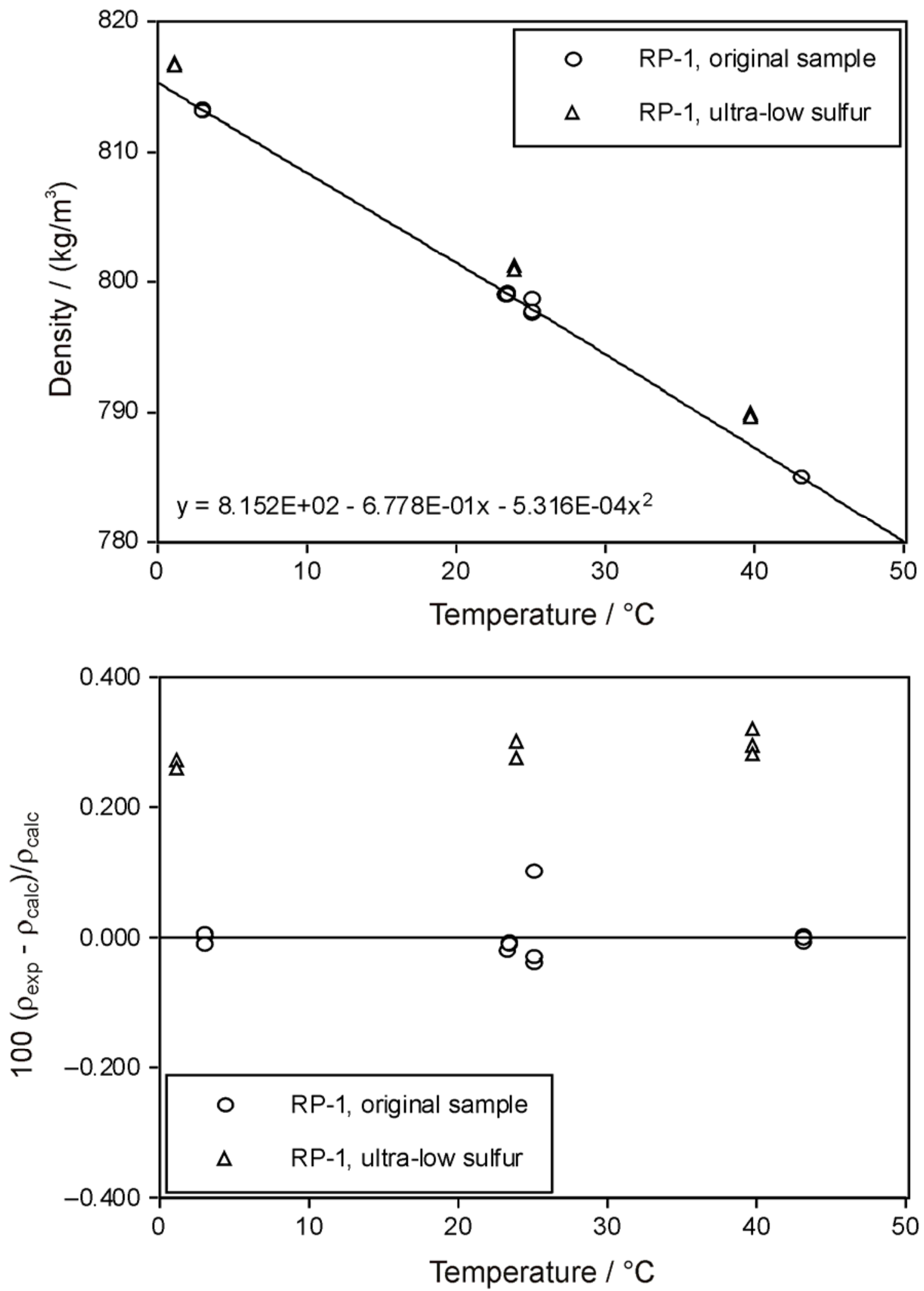

Figure 1. Density of RP-1 at atmospheric pressure; (a) measured densities; (b) deviations of density from the simple polynomial correlation. 


\subsection{Density at Elevated Pressures}

Densities were measured with a constant-volume piezometer that operates at conditions up to $745 \mathrm{~K}$ and $60 \mathrm{MPa}$. This study was carried out under a contract to Prof. Ilmudin M. Abdulagatov (Russian Academy of Sciences, Makhachkala) who set up a collaborative project with Prof. Nazim D. Azizov (Azerbaijan State Oil Academy (ASOA), Baku). The uncertainty estimated by ASOA for the density measurements is $0.5 \mathrm{~kg} \cdot \mathrm{m}^{-3}$ (for $\mathrm{T}<623 \mathrm{~K}$ ) and $0.1 \%$ (for $\mathrm{T}>623 \mathrm{~K}$ ). Those experimental data were privately communicated to NIST and were used, in addition to NIST measurements, to develop the models discussed in Section 2. 


\section{Heat Capacity}

Heat capacities are fundamental to our knowledge of the thermal properties of any substance or mixture. They may be regarded as a measure of the rate of change of energy storage in molecular systems. Heat capacity is defined by the operational path taken during an exchange of energy with the surroundings; the path may be at a constant pressure, at constant density, or along a phase saturation curve. In practice, we may measure a change in enthalpy at constant pressure $C_{\mathrm{p}}$ or a change in internal energy at constant volume $C_{\mathrm{v}}$. However, it is not possible to measure a heat capacity at a fixed pressure condition of vapor-liquid saturation. This is so because an addition of a small quantity of energy will evaporate a portion of the sample but will not raise its temperature, and thus an infinite heat capacity would be calculated. On the other hand, it is feasible to directly measure heat capacity in the vapor-liquid two-phase region, $C_{\mathrm{v}}^{(2)}$, and then calculate the saturated liquid heat capacity from well-established thermodynamic relations.

Heat capacities at constant pressure were measured with a flow calorimeter that operates at conditions up to $671 \mathrm{~K}$ and $60 \mathrm{MPa}$. This study was carried out under a contract to Prof. Ilmudin M. Abdulagatov (Russian Academy of Sciences, Makhachkala) who set up a collaborative project with Prof. Nazim D. Azizov (Azerbaijan State Oil Academy (ASOA), Baku). The uncertainty estimated by ASOA for the heat capacity measurements is $2 \%$ (for $\mathrm{T}<573 \mathrm{~K}$ ) and 3 to $4 \%$ (for $\mathrm{T}>573 \mathrm{~K}$ ). Those experimental data were privately communicated to NIST and were used, in addition to NIST measurements, to develop the models discussed in Section 2. 


\section{Thermal Conductivity}

Transient hot-wire measurements of the thermal conductivity of the RP-1 liquid sample were made along nine isotherms at temperatures from 300 to $700 \mathrm{~K}$ with pressures up to $70 \mathrm{MPa}$. Rapid decomposition was observed at $700 \mathrm{~K}$. Only data up to $650 \mathrm{~K}$ ( 8 isotherms) are shown in Figure 2. The transient hot-wire instrument has been described in detail. The measurement cell is designed to closely approximate transient heating from a line source into an infinite fluid medium. The ideal (line source) temperature rise $\Delta T_{\text {id }}$ is given by,

$$
\Delta T_{i d}=\frac{q}{4 \pi \lambda}\left[\ln (t)+\ln \left(\frac{4 a}{r_{0}{ }^{2} C}\right)\right]=\Delta T_{w}+\sum_{i=1}^{10} \delta T_{i},
$$

where $q$ is the power applied per unit length, $\lambda$ is the thermal conductivity of the fluid, $t$ is the elapsed time, $a=\lambda / \rho C_{\mathrm{p}}$ is the thermal diffusivity of the fluid, $\rho$ is the density of the fluid, $C_{\mathrm{p}}$ is the isobaric specific heat capacity of the fluid, $r_{0}$ is the radius of the hot wire, $C=1.781 \ldots$ is the exponential of Euler's constant, $\Delta T_{\mathrm{w}}$ is the measured temperature rise of the wire, and $\delta T_{i}$ are corrections to account for deviations from ideal line-source conduction. The significant corrections for the RP-1 measurements are for the finite wire diameter and thermal radiation from the IR absorbing fluid. A plot of ideal temperature rise versus logarithm of elapsed time should be linear, such that thermal conductivity can be found from the slope, and thermal diffusivity can be found from the intercept of a line fit to the data.

At time zero, a fixed voltage is applied to heat a small-diameter wire that is immersed in the fluid of interest. The wire is used as an electrical heat source, while its resistance increase allows determination of the transient temperature rise as a function of elapsed time. Two tungsten wires that have different lengths but the same $4 \mu \mathrm{m}$ diameter are connected such that the response of the 
short wire is subtracted from the response of the long wire to eliminate the effects of axial heat conduction. Short experiment times (nominally $1 \mathrm{~s}$ ) and small temperature rises (nominally 1 to 3 K) are selected to eliminate heat transfer by free convection. Experiments at several different heating powers (and temperature rises) allow verification that free convection is not significant. Heat transfer due to thermal radiation is more difficult to detect and correct when the fluid can absorb and re-emit infrared radiation such as RP-1. Thermal radiative heat transfer will increase roughly in proportion to the absolute temperature cubed and can be characterized from an increase in the apparent thermal conductivity as experiment time increases because radiative emission from the fluid increases as the thermal wave diffuses outward. Measurements of argon gas made prior to the RP-1 measurements verified that the apparatus was performing correctly.

The results of 465 transient hot-wire measurements are given in Table 10 for temperatures from $300 \mathrm{~K}$ to $650 \mathrm{~K}$. Each experiment is characterized by the initial cell temperature $T_{0}$ and the mean experiment temperature $T_{\mathrm{e}}$. There are generally five experiments at each initial cell temperature to verify that convection was not significant, since convection depends strongly on the temperature rise $\left(\Delta T=T_{\mathrm{e}}-T_{0}\right)$. The conditions of the fluid during each measurement are given by the experimental temperature $T_{\mathrm{e}}$, pressure $P_{\mathrm{e}}$, and density $\rho_{\mathrm{e}}$. Two values of measured thermal conductivity are reported. The thermal conductivity without correction for thermal radiation is given by $\lambda_{\mathrm{e}}$, while the value corrected for thermal radiation is given by $\lambda_{\mathrm{c}}$. The magnitude of the radiation correction can be found through comparison of these two values and varies from $0.1 \%$ at $300 \mathrm{~K}$ to $3.5 \%$ at $550 \mathrm{~K}$, increasing to $6.6 \%$ at $650 \mathrm{~K}$. Both values of thermal conductivity are provided for comparison with literature data where the radiation correction has often not been considered. Details of the thermal radiation correction and validation of its use with liquid toluene have been presented elsewhere. Measured thermal conductivity data for RP-1, corrected for 
thermal radiation, are shown in Figure 3. Empirical values for the product of the mean absorption coefficient times the refractive index squared $\left(\mathrm{Kn}^{2}\right)$ are provided in Figure 4 as a function of fluid density (temperatures range from $300 \mathrm{~K}$ to $650 \mathrm{~K}$ ). The solid line is given by a cubic polynomial fit in terms of density; the fit was used to correct the transient hot-wire data for thermal radiation.

Measurements were made at increasing temperatures on the original sample from $300 \mathrm{~K}$ to $600 \mathrm{~K}$. The sample was collected for chemical analysis and the cell was charged with fresh RP-1 for measurements at $650 \mathrm{~K}$. The $650 \mathrm{~K}$ sample was collected and the cell was charged again with fresh sample for the $700 \mathrm{~K}$ isotherm. Rapid decomposition of the RP-1 sample was observed at $700 \mathrm{~K}$. Measured thermal conductivity at $700 \mathrm{~K}$ was significantly higher and inconsistent with values obtained at lower temperatures. The $700 \mathrm{~K}$ sample was collected and the three samples were analyzed for decomposition by gas chromatography-mass spectrometry-infrared detection (GC-MS-IR). There is clear evidence in the $650 \mathrm{~K}$ sample of sample reactions and discoloration with a significant increase in aromatics, including heavier aromatics such as naphthalenic compounds. The $700 \mathrm{~K}$ sample shows the predominance of these reactions with a further significant increase in aromatic and napthalenic components.

After significant reactions were observed at $700 \mathrm{~K}$, a study of measured thermal conductivity as a function of residence time at $650 \mathrm{~K}$ was made. After filling and initial temperature equilibration at $650 \mathrm{~K}$, there was a steady increase in cell pressure and decrease in cell temperature. While this would be characteristic of cracking reactions, which are endothermic and produce products of low molecular weight, chemical analysis suggests that other reactions are also responsible for the observed changes. The pressure increase was from 13.1 MPa to 14.8 MPa over a $9 \mathrm{~h}$ period. The thermal conductivity increased by $0.3 \%$ over the same period, while the temperature decreased by $0.4 \mathrm{~K}$. This thermal conductivity is $2.4 \%$ smaller than expected based 
on the changes in temperature and pressure. Thus, the thermal conductivity changes by about $2 \%$ due to changes in sample composition during this period at $650 \mathrm{~K}$. This new isotherm agreed with the previous measurements at $650 \mathrm{~K}$ to within about $3 \%$. However, some of this disagreement is likely due to a solid coating that was present on the hot wires after exposure to the RP-1 sample at $700 \mathrm{~K}$.

Figure 5 shows significant deposits of solid material that were found on the hot wires after measurements at $700 \mathrm{~K}$. It appears that the material was molten but nonvolatile when the RP-1 sample was flashed and removed at $700 \mathrm{~K}$. Small diameter cylindrical sections that are only slightly larger than the wire diameter are seen between the larger "beads". The spherical-bead shape of the deposits was likely due to minimization of interfacial forces at the molten film-wire and film-gas boundaries. Measurements were made on liquid toluene near $300 \mathrm{~K}$ after the measurements at $700 \mathrm{~K}$ and excellent agreement ( $0.3 \%$ difference) was found with reference data for the thermal conductivity of toluene even with the presence of the solid material on the wire. Thus, the thermal conductivity of the solid deposit is likely close to that of toluene, an aromatic material, but slightly different from` that of the original RP-1 sample. The deposit was not soluble in toluene at $300 \mathrm{~K}$.

The uncertainty of the measured thermal conductivity data is less than $0.5 \%$ for temperatures from 300 to $450 \mathrm{~K}$ where decomposition and thermal radiation were not significant. At higher temperatures, the uncertainty increases due to sample decomposition and increased thermal radiation heat transfer. This uncertainty is about $1.0 \%$ at $550 \mathrm{~K}$ and increases significantly when the effects of decomposition are observable in the measured thermal conductivity as a function of sample residence time at $650 \mathrm{~K}$. At $650 \mathrm{~K}$ the uncertainty is about $4 \%$, due largely to changes in sample composition. 
Deviations between the measured thermal conductivity data, corrected for thermal radiation, and the corresponding states model developed in this project for the thermal conductivity of RP-1 are shown in Figure 6 . The deviations are generally within $3 \%$ for temperatures between $300 \mathrm{~K}$ and $400 \mathrm{~K}$, but the model is systematically higher than the data as the density decreases along an isotherm and as temperature increases. The model is systematically $4 \%$ to $12 \%$ higher than the data along the $650 \mathrm{~K}$ isotherm. The data for each isotherm are consistent within the uncertainties given above, both within the isotherm and among the eight isotherms. There are some "discontinuities" of the order of $1 \%$ in the deviation plot along the higher temperature isotherms. These "discontinuities" are not present in the measured thermal conductivity data, as shown in Figure 3. This is likely a convergence issue in the corresponding states model that would have a small impact on designs based on this model for the thermal conductivity of RP-1. The corresponding states model is based on thermal conductivity data for pure components that typically have not been corrected for thermal radiation. Thus it is expected that the corresponding states model will predict higher thermal conductivities, more like the uncorrected thermal conductivity values for RP-1 measured in this work. The correction for thermal radiation was as large as $6.6 \%$ at the lowest densities along the $650 \mathrm{~K}$ isotherm. Thermal radiation accounts for about half of the systematic deviations shown in Figure 6. A thorough development of the corresponding states model would need to consider the contribution of thermal radiation on the pure components used in the model. 


\section{Bibliography for Thermal Conductivity}

Perkins, R. A.; Roder, H. M.; Nieto de Castro, C. A. A high-temperature transient hot-wire thermal conductivity apparatus for fluids. J. Res. Natl. Inst. Stand. Tech. 96: 247-269 (1991).

Nieto de Castro, C. A.; Perkins, R. A.; Roder, H. M. Radiative heat transfer in transient hot-wire measurements of thermal conductivity. Int. J. Thermophys. 12: 985-997 (1991).

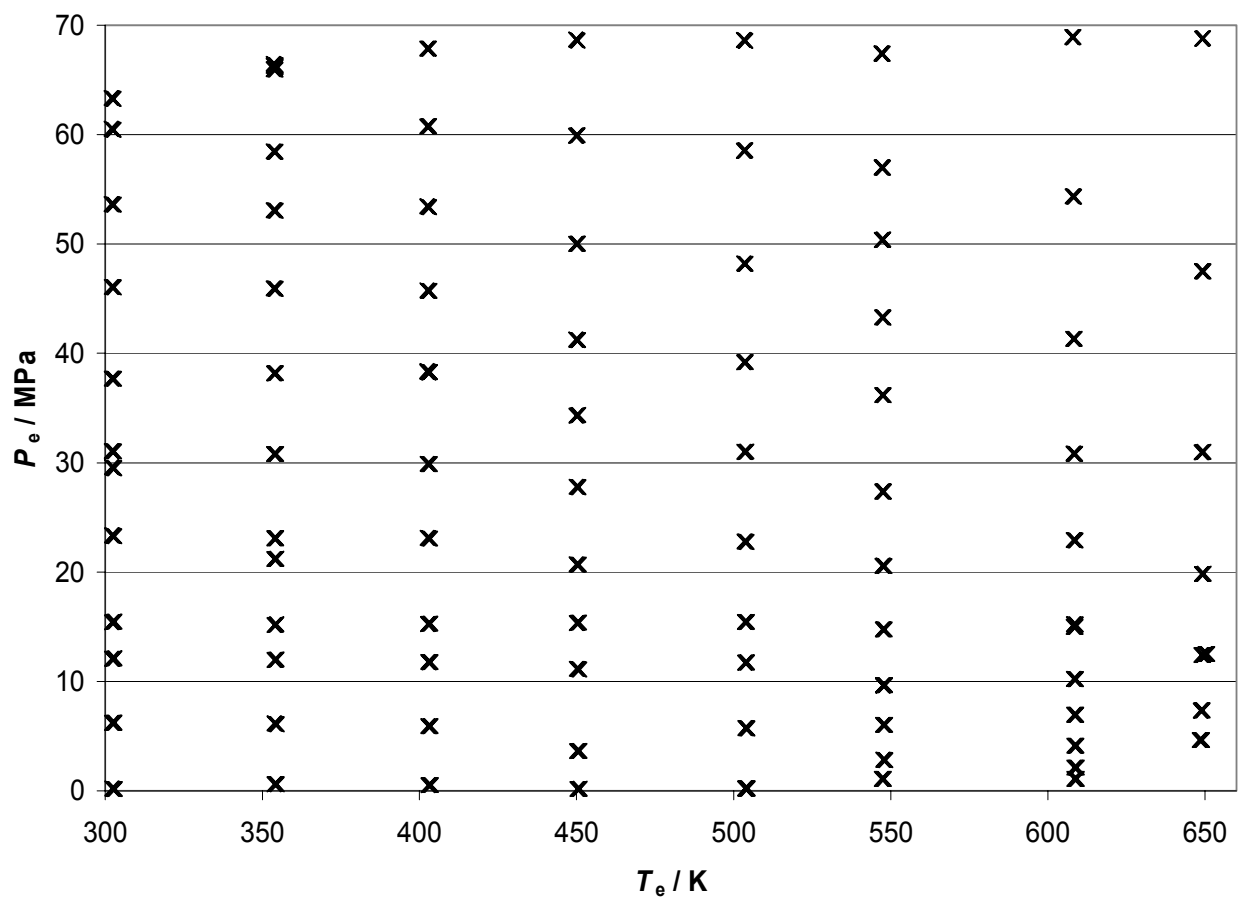

Figure 2. Range of thermal conductivity measurements on liquid RP-1. 


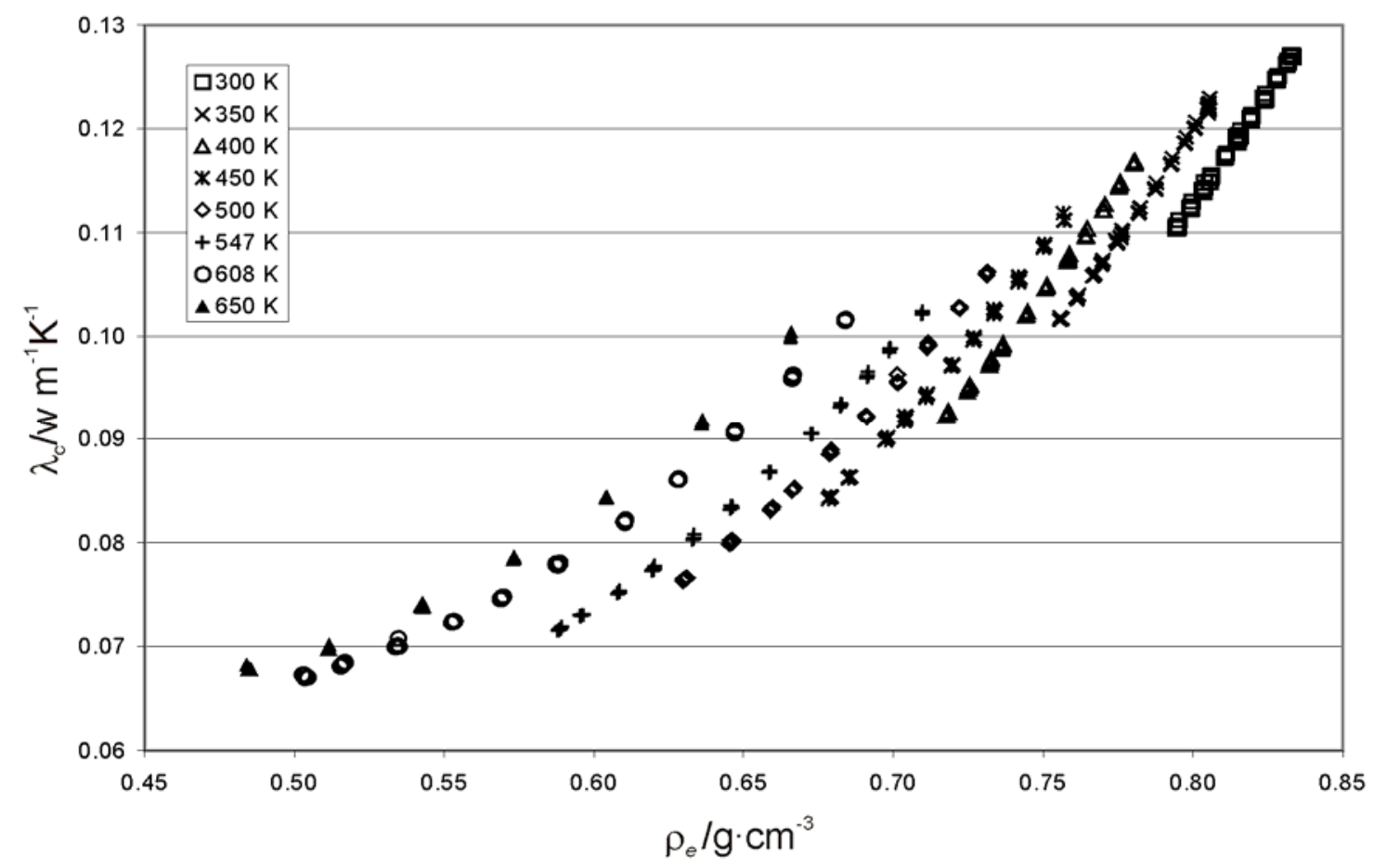

Figure 3. Measured thermal conductivity of RP-1 corrected for thermal radiation (pressure from $0.1 \mathrm{MPa}$ to $70 \mathrm{MPa}$ ).

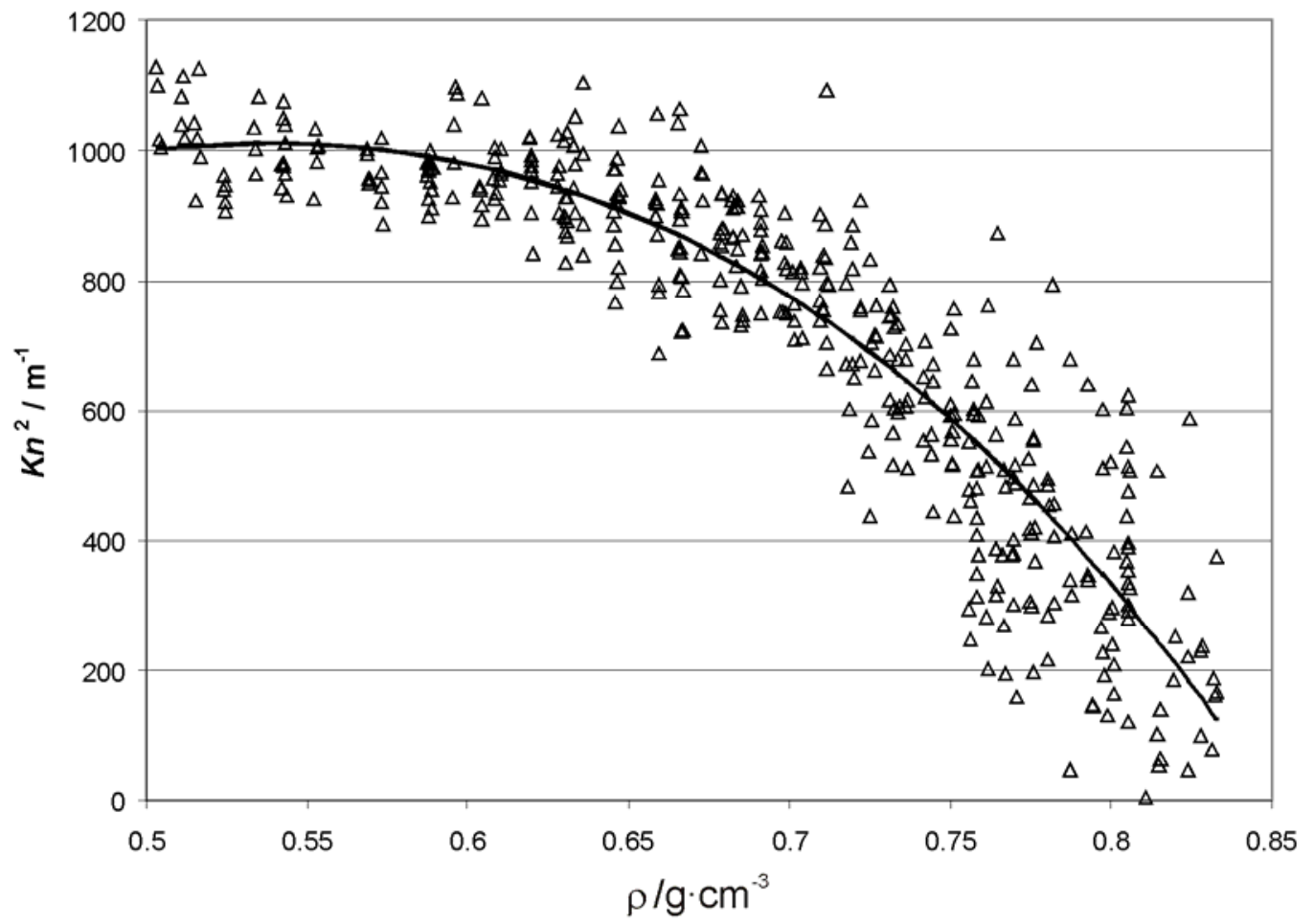

Figure 4. Empirical optical parameters for radiation correction of RP-1 data. 


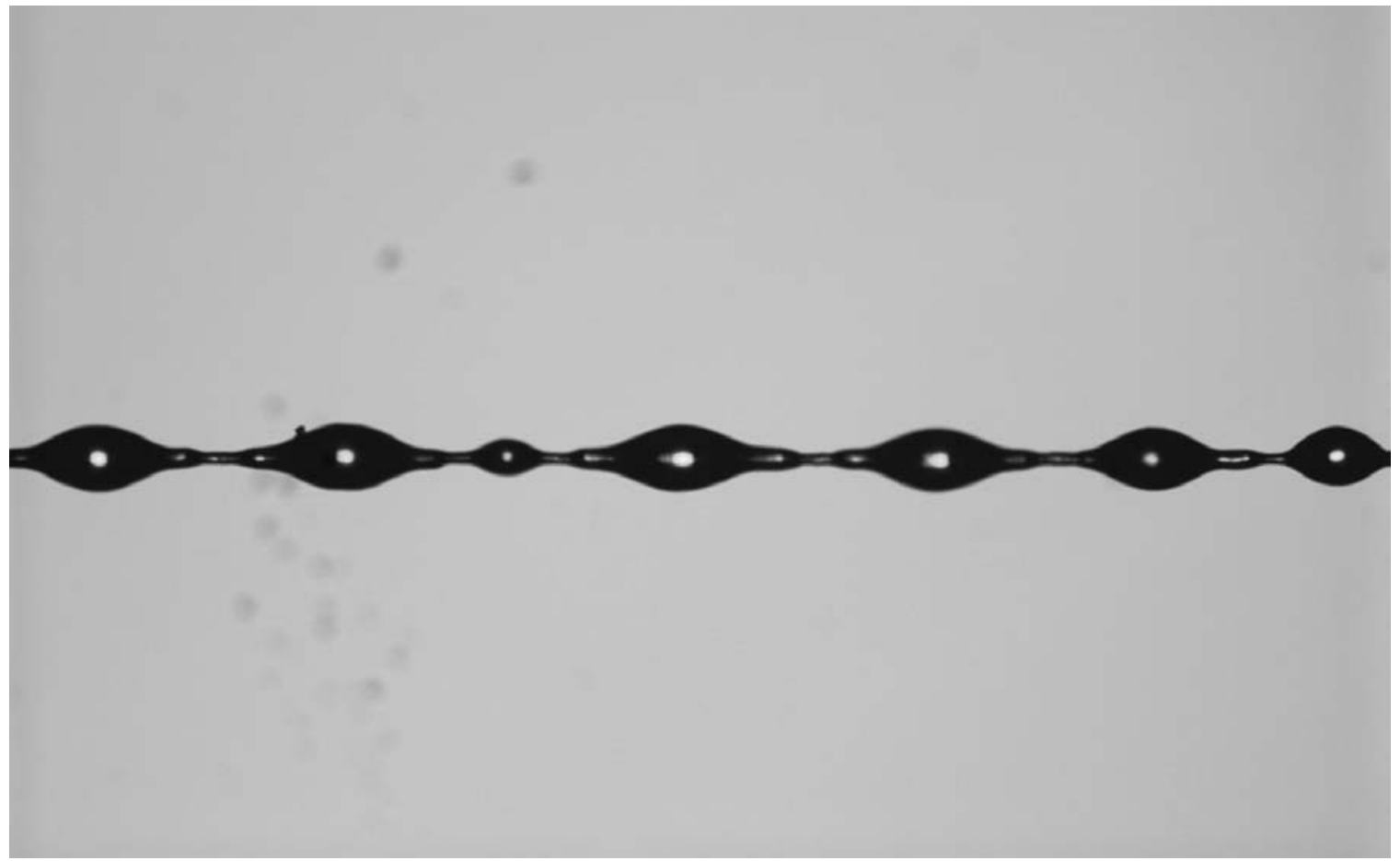

Figure 5. Solid deposits with diameters up to eight times that of the $4 \mu \mathrm{m}$ hot wires were found after measurements on RP-1 at $650 \mathrm{~K}$.

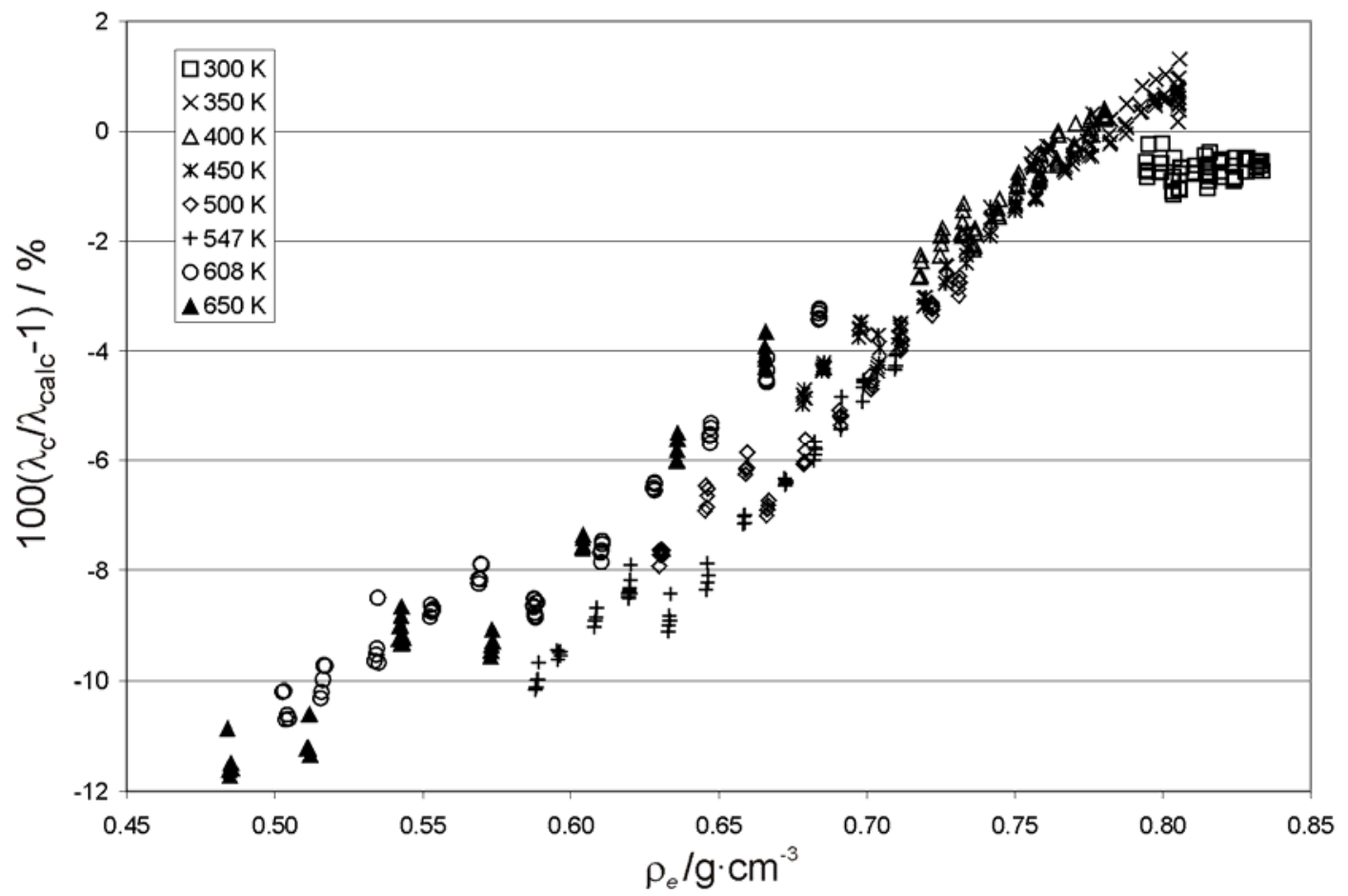

Figure 6. Deviations between the radiation corrected thermal conductivity data and the corresponding-states model for RP-1 developed in this work. 
Table 10. Thermal conductivity of liquid RP-1.

\begin{tabular}{|c|c|c|c|c|c|c|}
\hline Point ID & $\begin{array}{c}T_{0} \\
(\mathbf{K})\end{array}$ & $\begin{array}{c}T_{\mathbf{e}} \\
(\mathbf{K})\end{array}$ & $\begin{array}{c}P_{\mathrm{e}} \\
(\mathbf{M P a})\end{array}$ & $\begin{array}{c}\rho_{\mathrm{e}} \\
\left(\mathrm{g} \cdot \mathrm{cm}^{-3}\right)\end{array}$ & $\begin{array}{c}\lambda_{\mathrm{e}} \\
\left(\mathbf{W} \cdot \mathbf{m}^{-1} \mathbf{K}^{-1}\right)\end{array}$ & $\begin{array}{c}\lambda_{\mathrm{c}} \\
\left(\mathbf{W} \cdot \mathbf{m}^{-1} \mathbf{K}^{-1}\right)\end{array}$ \\
\hline 2001 & 299.998 & 301.798 & 63.3444 & 0.83331 & 0.12705 & 0.12695 \\
\hline 2002 & 299.998 & 302.036 & 63.3249 & 0.83316 & 0.12722 & 0.12712 \\
\hline 2003 & 300.003 & 302.302 & 63.3083 & 0.83299 & 0.12710 & 0.12700 \\
\hline 2004 & 300.004 & 302.559 & 63.2909 & 0.83283 & 0.12716 & 0.12706 \\
\hline 2005 & 300.002 & 302.834 & 63.2699 & 0.83266 & 0.12712 & 0.12702 \\
\hline 2006 & 299.985 & 301.802 & 60.5341 & 0.83192 & 0.12667 & 0.12656 \\
\hline 2007 & 299.991 & 302.041 & 60.5107 & 0.83177 & 0.12659 & 0.12649 \\
\hline 2008 & 300.002 & 302.302 & 60.4845 & 0.83160 & 0.12640 & 0.12633 \\
\hline 2009 & 300.006 & 302.571 & 60.4609 & 0.83143 & 0.12631 & 0.12620 \\
\hline 2010 & 300.003 & 302.844 & 60.4359 & 0.83125 & 0.12632 & 0.12621 \\
\hline 2011 & 300.002 & 301.837 & 53.6465 & 0.82842 & 0.12523 & 0.12508 \\
\hline 2012 & 300.018 & 302.092 & 53.6341 & 0.82825 & 0.12512 & 0.12499 \\
\hline 2013 & 300.016 & 302.343 & 53.6227 & 0.82809 & 0.12479 & 0.12467 \\
\hline 2014 & 300.025 & 302.616 & 53.6114 & 0.82792 & 0.12475 & 0.12462 \\
\hline 2015 & 300.037 & 302.909 & 53.5993 & 0.82774 & 0.12495 & 0.12483 \\
\hline 2016 & 300.021 & 301.875 & 46.0715 & 0.82440 & 0.12346 & 0.12332 \\
\hline 2017 & 300.028 & 302.121 & 46.0630 & 0.82424 & 0.12295 & 0.12283 \\
\hline 2018 & 300.030 & 302.383 & 46.0541 & 0.82408 & 0.12287 & 0.12274 \\
\hline 2019 & 300.026 & 302.648 & 46.0468 & 0.82391 & 0.12280 & 0.12265 \\
\hline 2020 & 300.036 & 302.946 & 46.0404 & 0.82372 & 0.12317 & 0.12295 \\
\hline 2021 & 300.002 & 301.892 & 37.7058 & 0.81977 & 0.12145 & 0.12129 \\
\hline 2022 & 300.000 & 302.132 & 37.7019 & 0.81961 & 0.12139 & 0.12122 \\
\hline 2023 & 300.011 & 302.401 & 37.6976 & 0.81944 & 0.12100 & 0.12080 \\
\hline 2024 & 300.008 & 302.674 & 37.6932 & 0.81926 & 0.12105 & 0.12088 \\
\hline 2025 & 300.021 & 302.976 & 37.6688 & 0.81905 & 0.12118 & 0.12102 \\
\hline 2026 & 299.999 & 301.908 & 31.0595 & 0.81591 & 0.11999 & 0.11981 \\
\hline 2027 & 299.996 & 302.152 & 31.0539 & 0.81574 & 0.11942 & 0.11924 \\
\hline 2028 & 300.011 & 302.427 & 31.0473 & 0.81556 & 0.11944 & 0.11926 \\
\hline 2029 & 300.006 & 302.702 & 31.0387 & 0.81537 & 0.11922 & 0.11903 \\
\hline 2030 & 300.016 & 303.006 & 31.0311 & 0.81517 & 0.11955 & 0.11936 \\
\hline 2031 & 300.043 & 301.953 & 29.6071 & 0.81501 & 0.11886 & 0.11867 \\
\hline 2032 & 300.056 & 302.217 & 29.5643 & 0.81481 & 0.11923 & 0.11905 \\
\hline 2033 & 300.052 & 302.479 & 29.5309 & 0.81462 & 0.11907 & 0.11889 \\
\hline 2034 & 300.062 & 302.767 & 29.5057 & 0.81441 & 0.11914 & 0.11895 \\
\hline 2035 & 300.051 & 303.052 & 29.5016 & 0.81422 & 0.11936 & 0.11916 \\
\hline 2036 & 300.011 & 301.954 & 23.3521 & 0.81119 & 0.11786 & 0.11759 \\
\hline 2037 & 300.022 & 302.214 & 23.3541 & 0.81101 & 0.11777 & 0.11753 \\
\hline 2038 & 300.028 & 302.486 & 23.3358 & 0.81081 & 0.11751 & 0.11731 \\
\hline 2039 & 300.030 & 302.771 & 23.3001 & 0.81060 & 0.11744 & 0.11723 \\
\hline 2040 & 300.039 & 303.078 & 23.2702 & 0.81037 & 0.11742 & 0.11721 \\
\hline 2041 & 300.011 & 301.986 & 15.4211 & 0.80605 & 0.11570 & 0.11548 \\
\hline 2042 & 300.012 & 302.240 & 15.4388 & 0.80588 & 0.11567 & 0.11544 \\
\hline
\end{tabular}


Table 10. Thermal conductivity of liquid RP-1.

\begin{tabular}{|c|c|c|c|c|c|c|}
\hline Point ID & $\begin{array}{c}T_{0} \\
(\mathbf{K})\end{array}$ & $\begin{array}{c}T_{\mathbf{e}} \\
(\mathbf{K})\end{array}$ & $\begin{array}{c}P_{\mathrm{e}} \\
(\mathrm{MPa})\end{array}$ & $\begin{array}{c}\rho_{\mathrm{e}} \\
\left(\mathrm{g} \cdot \mathrm{cm}^{-3}\right)\end{array}$ & $\begin{array}{c}\lambda_{\mathrm{e}} \\
\left(\mathbf{W} \cdot \mathbf{m}^{-1} K^{-1}\right)\end{array}$ & $\begin{array}{c}\lambda_{\mathrm{c}} \\
\left(\mathbf{W} \cdot \mathbf{m}^{-1} \mathbf{K}^{-1}\right)\end{array}$ \\
\hline 2043 & 300.027 & 302.526 & 15.4583 & 0.80569 & 0.11547 & 0.11525 \\
\hline 2044 & 300.010 & 302.795 & 15.4736 & 0.80551 & 0.11511 & 0.11488 \\
\hline 2045 & 300.025 & 303.113 & 15.4863 & 0.80530 & 0.11509 & 0.11486 \\
\hline 2046 & 299.997 & 301.983 & 12.0832 & 0.80380 & 0.11504 & 0.11481 \\
\hline 2047 & 300.016 & 302.262 & 12.0704 & 0.80359 & 0.11456 & 0.11432 \\
\hline 2048 & 300.007 & 302.526 & 12.0827 & 0.80341 & 0.11420 & 0.11393 \\
\hline 2049 & 300.022 & 302.828 & 12.1065 & 0.80321 & 0.11422 & 0.11395 \\
\hline 2050 & 300.011 & 303.123 & 12.1261 & 0.80301 & 0.11434 & 0.11410 \\
\hline 2051 & 299.987 & 302.001 & 6.2210 & 0.79967 & 0.11324 & 0.11299 \\
\hline 2052 & 299.995 & 302.270 & 6.2334 & 0.79948 & 0.11278 & 0.11253 \\
\hline 2053 & 300.013 & 302.565 & 6.2425 & 0.79927 & 0.11257 & 0.11232 \\
\hline 2054 & 300.012 & 302.857 & 6.2477 & 0.79906 & 0.11251 & 0.11225 \\
\hline 2055 & 300.015 & 303.168 & 6.2466 & 0.79883 & 0.11263 & 0.11238 \\
\hline 2056 & 299.988 & 302.028 & 0.2179 & 0.79520 & 0.11148 & 0.11122 \\
\hline 2057 & 299.999 & 302.308 & 0.1941 & 0.79497 & 0.11086 & 0.11060 \\
\hline 2058 & 300.003 & 302.594 & 0.1755 & 0.79474 & 0.11070 & 0.11043 \\
\hline 2059 & 300.003 & 302.892 & 0.1675 & 0.79450 & 0.11101 & 0.11067 \\
\hline 2060 & 300.001 & 303.204 & 0.1792 & 0.79428 & 0.11072 & 0.11045 \\
\hline 3001 & 351.854 & 353.436 & 66.4743 & 0.80567 & 0.12331 & 0.12296 \\
\hline 3002 & 351.854 & 353.659 & 66.4227 & 0.80551 & 0.12212 & 0.12177 \\
\hline 3003 & 351.870 & 353.904 & 66.3775 & 0.80535 & 0.12219 & 0.12184 \\
\hline 3004 & 351.861 & 354.161 & 66.3535 & 0.80520 & 0.12179 & 0.12144 \\
\hline 3005 & 351.865 & 354.379 & 66.3472 & 0.80508 & 0.12268 & 0.12236 \\
\hline 3006 & 351.845 & 353.439 & 66.2878 & 0.80556 & 0.12285 & 0.12250 \\
\hline 3007 & 351.847 & 353.706 & 66.2729 & 0.80540 & 0.12228 & 0.12189 \\
\hline 3008 & 351.865 & 353.900 & 66.2542 & 0.80529 & 0.12236 & 0.12197 \\
\hline 3009 & 351.846 & 354.127 & 66.2306 & 0.80515 & 0.12232 & 0.12196 \\
\hline 3010 & 351.858 & 354.367 & 66.1862 & 0.80499 & 0.12238 & 0.12202 \\
\hline 3011 & 351.847 & 353.444 & 65.9787 & 0.80538 & 0.12248 & 0.12212 \\
\hline 3012 & 351.846 & 353.647 & 65.9703 & 0.80526 & 0.12250 & 0.12214 \\
\hline 3013 & 351.849 & 353.872 & 65.9607 & 0.80513 & 0.12252 & 0.12216 \\
\hline 3014 & 351.850 & 354.104 & 65.9512 & 0.80500 & 0.12246 & 0.12211 \\
\hline 3015 & 351.856 & 354.356 & 65.9398 & 0.80486 & 0.12229 & 0.12193 \\
\hline 3016 & 351.828 & 353.438 & 58.4753 & 0.80097 & 0.12102 & 0.12064 \\
\hline 3017 & 351.825 & 353.652 & 58.4373 & 0.80083 & 0.12042 & 0.12004 \\
\hline 3018 & 351.843 & 353.889 & 58.4229 & 0.80069 & 0.12051 & 0.12013 \\
\hline 3019 & 351.839 & 354.120 & 58.4251 & 0.80056 & 0.12034 & 0.11995 \\
\hline 3020 & 351.832 & 354.361 & 58.4319 & 0.80043 & 0.12045 & 0.12006 \\
\hline 3021 & 351.823 & 353.454 & 53.0937 & 0.79767 & 0.11957 & 0.11917 \\
\hline 3022 & 351.827 & 353.671 & 53.0800 & 0.79753 & 0.11895 & 0.11856 \\
\hline 3023 & 351.836 & 353.904 & 53.0655 & 0.79739 & 0.11905 & 0.11865 \\
\hline 3024 & 351.834 & 354.140 & 53.0528 & 0.79725 & 0.11897 & 0.11857 \\
\hline 3025 & 351.839 & 354.396 & 53.0392 & 0.79709 & 0.11907 & 0.11866 \\
\hline
\end{tabular}


Table 10. Thermal conductivity of liquid RP-1.

\begin{tabular}{|c|c|c|c|c|c|c|}
\hline Point ID & $\begin{array}{c}T_{0} \\
(\mathbf{K})\end{array}$ & $\begin{array}{c}T_{\mathbf{e}} \\
(\mathbf{K})\end{array}$ & $\begin{array}{c}P_{\mathrm{e}} \\
(\mathrm{MPa})\end{array}$ & $\begin{array}{c}\rho_{\mathrm{e}} \\
\left(\mathrm{g} \cdot \mathrm{cm}^{-3}\right)\end{array}$ & $\begin{array}{c}\lambda_{\mathrm{e}} \\
\left(\mathbf{W} \cdot \mathbf{m}^{-1} K^{-1}\right)\end{array}$ & $\begin{array}{c}\lambda_{\mathrm{c}} \\
\left(\mathrm{W} \cdot \mathrm{m}^{-1} \mathbf{K}^{-1}\right)\end{array}$ \\
\hline 3026 & 351.829 & 353.484 & 45.9442 & 0.79308 & 0.11759 & 0.11716 \\
\hline 3027 & 351.823 & 353.698 & 45.9346 & 0.79295 & 0.11702 & 0.11660 \\
\hline 3028 & 351.833 & 353.936 & 45.9234 & 0.79280 & 0.11698 & 0.11655 \\
\hline 3029 & 351.838 & 354.184 & 45.9124 & 0.79265 & 0.11707 & 0.11664 \\
\hline 3030 & 351.823 & 354.424 & 45.9021 & 0.79250 & 0.11690 & 0.11647 \\
\hline 3031 & 351.816 & 353.500 & 38.1685 & 0.78782 & 0.11518 & 0.11472 \\
\hline 3032 & 351.816 & 353.724 & 38.1724 & 0.78769 & 0.11464 & 0.11419 \\
\hline 3033 & 351.830 & 353.969 & 38.1784 & 0.78754 & 0.11448 & 0.11403 \\
\hline 3034 & 351.829 & 354.213 & 38.1884 & 0.78740 & 0.11466 & 0.11421 \\
\hline 3035 & 351.826 & 354.471 & 38.1983 & 0.78725 & 0.11463 & 0.11417 \\
\hline 3036 & 351.808 & 353.523 & 30.8077 & 0.78253 & 0.11286 & 0.11238 \\
\hline 3037 & 351.817 & 353.757 & 30.8057 & 0.78238 & 0.11233 & 0.11189 \\
\hline 3038 & 351.833 & 354.008 & 30.8008 & 0.78222 & 0.11279 & 0.11231 \\
\hline 3039 & 351.831 & 354.258 & 30.7953 & 0.78206 & 0.11226 & 0.11178 \\
\hline 3040 & 351.837 & 354.528 & 30.7900 & 0.78189 & 0.11240 & 0.11192 \\
\hline 3041 & 351.816 & 353.568 & 23.0974 & 0.77660 & 0.11061 & 0.11011 \\
\hline 3042 & 351.825 & 353.808 & 23.0969 & 0.77645 & 0.11034 & 0.10983 \\
\hline 3043 & 351.823 & 354.045 & 23.0942 & 0.77629 & 0.11074 & 0.11023 \\
\hline 3044 & 351.835 & 354.313 & 23.0907 & 0.77611 & 0.10987 & 0.10936 \\
\hline 3045 & 351.827 & 354.573 & 23.0858 & 0.77594 & 0.11005 & 0.10954 \\
\hline 3046 & 351.849 & 353.609 & 21.2003 & 0.77506 & 0.10942 & 0.10891 \\
\hline 3047 & 351.849 & 353.840 & 21.2056 & 0.77491 & 0.10962 & 0.10911 \\
\hline 3048 & 351.868 & 354.104 & 21.2109 & 0.77474 & 0.10941 & 0.10890 \\
\hline 3049 & 351.873 & 354.364 & 21.2156 & 0.77457 & 0.10962 & 0.10911 \\
\hline 3050 & 351.864 & 354.629 & 21.2203 & 0.77440 & 0.10975 & 0.10923 \\
\hline 3051 & 351.845 & 353.642 & 15.1613 & 0.77001 & 0.10788 & 0.10735 \\
\hline 3052 & 351.848 & 353.875 & 15.1777 & 0.76986 & 0.10764 & 0.10711 \\
\hline 3053 & 351.861 & 354.135 & 15.1951 & 0.76970 & 0.10754 & 0.10701 \\
\hline 3054 & 351.853 & 354.390 & 15.2092 & 0.76954 & 0.10740 & 0.10687 \\
\hline 3055 & 351.846 & 354.657 & 15.2224 & 0.76936 & 0.10738 & 0.10684 \\
\hline 3056 & 351.832 & 353.645 & 11.9712 & 0.76722 & 0.10652 & 0.10598 \\
\hline 3057 & 351.859 & 353.905 & 11.9842 & 0.76704 & 0.10635 & 0.10581 \\
\hline 3058 & 351.868 & 354.163 & 11.9958 & 0.76687 & 0.10640 & 0.10585 \\
\hline 3059 & 351.864 & 354.424 & 12.0053 & 0.76670 & 0.10635 & 0.10580 \\
\hline 3060 & 351.862 & 354.700 & 12.0124 & 0.76651 & 0.10627 & 0.10573 \\
\hline 3061 & 351.813 & 353.659 & 6.1880 & 0.76188 & 0.10450 & 0.10394 \\
\hline 3062 & 351.828 & 353.909 & 6.1732 & 0.76168 & 0.10440 & 0.10383 \\
\hline 3063 & 351.840 & 354.178 & 6.1425 & 0.76146 & 0.10404 & 0.10348 \\
\hline 3064 & 351.840 & 354.448 & 6.1183 & 0.76124 & 0.10423 & 0.10367 \\
\hline 3065 & 351.845 & 354.737 & 6.0987 & 0.76101 & 0.10430 & 0.10374 \\
\hline 3066 & 351.818 & 353.696 & 0.6116 & 0.75633 & 0.10223 & 0.10165 \\
\hline 3067 & 351.845 & 353.967 & 0.6214 & 0.75614 & 0.10225 & 0.10167 \\
\hline 3068 & 351.847 & 354.228 & 0.6278 & 0.75594 & 0.10218 & 0.10159 \\
\hline
\end{tabular}


Table 10. Thermal conductivity of liquid RP-1.

\begin{tabular}{|c|c|c|c|c|c|c|}
\hline Point ID & $\begin{array}{c}T_{0} \\
(\mathbf{K})\end{array}$ & $\begin{array}{c}T_{\mathbf{e}} \\
(\mathbf{K})\end{array}$ & $\begin{array}{c}P_{\mathrm{e}} \\
(\mathrm{MPa})\end{array}$ & $\begin{array}{c}\rho_{\mathrm{e}} \\
\left(\mathrm{g} \cdot \mathrm{cm}^{-3}\right)\end{array}$ & $\begin{array}{c}\lambda_{\mathrm{e}} \\
\left(\mathbf{W} \cdot \mathbf{m}^{-1} \mathbf{K}^{-1}\right)\end{array}$ & $\begin{array}{c}\lambda_{\mathrm{c}} \\
\left(\mathbf{W} \cdot \mathbf{m}^{-1} \mathbf{K}^{-1}\right)\end{array}$ \\
\hline 3069 & 351.851 & 354.505 & 0.6282 & 0.75573 & 0.10237 & 0.10179 \\
\hline 3070 & 351.852 & 354.794 & 0.6056 & 0.75549 & 0.10213 & 0.10155 \\
\hline 4001 & 400.446 & 402.270 & 67.8698 & 0.78064 & 0.11752 & 0.11682 \\
\hline 4002 & 400.474 & 402.512 & 67.8711 & 0.78051 & 0.11731 & 0.11661 \\
\hline 4003 & 400.464 & 402.724 & 67.8715 & 0.78041 & 0.11797 & 0.11668 \\
\hline 4004 & 400.463 & 402.954 & 67.8743 & 0.78029 & 0.11748 & 0.11678 \\
\hline 4005 & 400.466 & 403.201 & 67.8738 & 0.78016 & 0.11730 & 0.11659 \\
\hline 4006 & 400.434 & 402.289 & 60.7558 & 0.77582 & 0.11560 & 0.11482 \\
\hline 4007 & 400.435 & 402.506 & 60.7558 & 0.77570 & 0.11542 & 0.11474 \\
\hline 4008 & 400.450 & 402.745 & 60.7602 & 0.77558 & 0.11528 & 0.11455 \\
\hline 4009 & 400.453 & 402.986 & 60.7647 & 0.77545 & 0.11524 & 0.11450 \\
\hline 4010 & 400.453 & 403.233 & 60.7700 & 0.77532 & 0.11508 & 0.11435 \\
\hline 4011 & 400.424 & 402.304 & 53.4350 & 0.77058 & 0.11347 & 0.11270 \\
\hline 4012 & 400.436 & 402.542 & 53.4325 & 0.77045 & 0.11291 & 0.11215 \\
\hline 4013 & 400.446 & 402.778 & 53.4091 & 0.77030 & 0.11289 & 0.11212 \\
\hline 4014 & 400.441 & 403.017 & 53.3763 & 0.77015 & 0.11292 & 0.11215 \\
\hline 4015 & 400.447 & 403.274 & 53.3494 & 0.76999 & 0.11292 & 0.11215 \\
\hline 4016 & 400.417 & 402.341 & 45.7511 & 0.76474 & 0.11113 & 0.11033 \\
\hline 4017 & 400.428 & 402.573 & 45.7250 & 0.76459 & 0.11118 & 0.11038 \\
\hline 4018 & 400.437 & 402.819 & 45.7046 & 0.76443 & 0.11054 & 0.10972 \\
\hline 4019 & 400.449 & 403.074 & 45.7046 & 0.76429 & 0.11051 & 0.10976 \\
\hline 4020 & 400.436 & 403.322 & 45.7239 & 0.76416 & 0.11041 & 0.10961 \\
\hline 4021 & 400.410 & 402.368 & 38.3898 & 0.75877 & 0.10869 & 0.10787 \\
\hline 4022 & 400.420 & 402.610 & 38.3544 & 0.75860 & 0.10823 & 0.10741 \\
\hline 4023 & 400.440 & 402.868 & 38.3270 & 0.75842 & 0.10815 & 0.10732 \\
\hline 4024 & 400.443 & 403.124 & 38.3062 & 0.75825 & 0.10806 & 0.10723 \\
\hline 4025 & 400.440 & 403.385 & 38.2888 & 0.75809 & 0.10800 & 0.10717 \\
\hline 4026 & 400.440 & 402.404 & 38.3049 & 0.75868 & 0.10862 & 0.10780 \\
\hline 4027 & 400.444 & 402.635 & 38.2825 & 0.75852 & 0.10840 & 0.10757 \\
\hline 4028 & 400.452 & 402.883 & 38.2644 & 0.75836 & 0.10810 & 0.10727 \\
\hline 4029 & 400.455 & 403.138 & 38.2591 & 0.75821 & 0.10806 & 0.10724 \\
\hline 4030 & 400.449 & 403.396 & 38.2724 & 0.75807 & 0.10833 & 0.10749 \\
\hline 4031 & 400.420 & 402.438 & 29.9102 & 0.75132 & 0.10580 & 0.10494 \\
\hline 4032 & 400.446 & 402.697 & 29.8883 & 0.75114 & 0.10567 & 0.10480 \\
\hline 4033 & 400.437 & 402.929 & 29.8703 & 0.75098 & 0.10553 & 0.10467 \\
\hline 4034 & 400.435 & 403.183 & 29.8701 & 0.75082 & 0.10546 & 0.10459 \\
\hline 4035 & 400.441 & 403.461 & 29.8844 & 0.75066 & 0.10543 & 0.10456 \\
\hline 4036 & 400.422 & 402.481 & 23.1390 & 0.74487 & 0.10323 & 0.10235 \\
\hline 4037 & 400.439 & 402.738 & 23.1129 & 0.74468 & 0.10287 & 0.10199 \\
\hline 4038 & 400.445 & 402.992 & 23.0911 & 0.74449 & 0.10291 & 0.10202 \\
\hline 4039 & 400.448 & 403.263 & 23.0714 & 0.74430 & 0.10296 & 0.10207 \\
\hline 4040 & 400.440 & 403.532 & 23.0644 & 0.74412 & 0.10279 & 0.10194 \\
\hline 4041 & 400.421 & 402.543 & 15.2520 & 0.73665 & 0.10018 & 0.09926 \\
\hline
\end{tabular}


Table 10. Thermal conductivity of liquid RP-1.

\begin{tabular}{|c|c|c|c|c|c|c|}
\hline Point ID & $\begin{array}{c}T_{0} \\
(\mathbf{K})\end{array}$ & $\begin{array}{c}T_{\mathbf{e}} \\
(\mathbf{K})\end{array}$ & $\begin{array}{c}P_{\mathrm{e}} \\
(\mathbf{M P a})\end{array}$ & $\begin{array}{c}\rho_{\mathrm{e}} \\
\left(\mathrm{g} \cdot \mathrm{cm}^{-3}\right)\end{array}$ & $\begin{array}{c}\lambda_{\mathrm{e}} \\
\left(\mathbf{W} \cdot \mathbf{m}^{-1} \mathbf{K}^{-1}\right)\end{array}$ & $\begin{array}{c}\lambda_{\mathrm{c}} \\
\left(\mathbf{W} \cdot \mathbf{m}^{-1} \mathbf{K}^{-1}\right)\end{array}$ \\
\hline 4042 & 400.409 & 402.774 & 15.2684 & 0.73651 & 0.10008 & 0.09916 \\
\hline 4043 & 400.434 & 403.053 & 15.2832 & 0.73633 & 0.09982 & 0.09890 \\
\hline 4044 & 400.432 & 403.324 & 15.2953 & 0.73616 & 0.09983 & 0.09891 \\
\hline 4045 & 400.447 & 403.626 & 15.3055 & 0.73597 & 0.09970 & 0.09877 \\
\hline 4046 & 400.428 & 402.578 & 11.7858 & 0.73274 & 0.09878 & 0.09785 \\
\hline 4047 & 400.433 & 402.827 & 11.7687 & 0.73254 & 0.09862 & 0.09769 \\
\hline 4048 & 400.443 & 403.097 & 11.7586 & 0.73234 & 0.09840 & 0.09746 \\
\hline 4049 & 400.437 & 403.369 & 11.7652 & 0.73216 & 0.09811 & 0.09718 \\
\hline 4050 & 400.441 & 403.661 & 11.7812 & 0.73197 & 0.09814 & 0.09721 \\
\hline 4051 & 400.415 & 402.618 & 5.9253 & 0.72564 & 0.09625 & 0.09530 \\
\hline 4052 & 400.417 & 402.870 & 5.9120 & 0.72544 & 0.09611 & 0.09516 \\
\hline 4053 & 400.430 & 403.150 & 5.9089 & 0.72523 & 0.09592 & 0.09496 \\
\hline 4054 & 400.423 & 403.423 & 5.9193 & 0.72504 & 0.09601 & 0.09506 \\
\hline 4055 & 400.429 & 403.726 & 5.9348 & 0.72483 & 0.09570 & 0.09469 \\
\hline 4056 & 400.407 & 402.659 & 0.5228 & 0.71842 & 0.09365 & 0.09268 \\
\hline 4057 & 400.420 & 402.929 & 0.5313 & 0.71822 & 0.09371 & 0.09274 \\
\hline 4058 & 400.419 & 403.200 & 0.5392 & 0.71802 & 0.09334 & 0.09237 \\
\hline 4059 & 400.419 & 403.490 & 0.5450 & 0.71780 & 0.09328 & 0.09231 \\
\hline 4060 & 400.435 & 403.808 & 0.5460 & 0.71755 & 0.09324 & 0.09227 \\
\hline 5001 & 447.986 & 449.670 & 68.6898 & 0.75732 & 0.11230 & 0.11117 \\
\hline 5002 & 447.991 & 449.870 & 68.6635 & 0.75721 & 0.11232 & 0.11118 \\
\hline 5003 & 447.993 & 450.077 & 68.6272 & 0.75708 & 0.11238 & 0.11119 \\
\hline 5004 & 447.983 & 450.283 & 68.5986 & 0.75695 & 0.11226 & 0.11112 \\
\hline 5005 & 447.989 & 450.514 & 68.5747 & 0.75682 & 0.11300 & 0.11184 \\
\hline 5006 & 447.928 & 449.652 & 59.8904 & 0.75048 & 0.11005 & 0.10887 \\
\hline 5007 & 447.966 & 449.886 & 59.9032 & 0.75037 & 0.10986 & 0.10868 \\
\hline 5008 & 447.944 & 450.075 & 59.9145 & 0.75029 & 0.10981 & 0.10863 \\
\hline 5009 & 447.939 & 450.291 & 59.9247 & 0.75018 & 0.10975 & 0.10856 \\
\hline 5010 & 447.935 & 450.518 & 59.9336 & 0.75008 & 0.10967 & 0.10848 \\
\hline 5011 & 447.904 & 449.679 & 49.9987 & 0.74213 & 0.10681 & 0.10558 \\
\hline 5012 & 447.905 & 449.882 & 50.0107 & 0.74203 & 0.10674 & 0.10551 \\
\hline 5013 & 447.907 & 450.099 & 50.0219 & 0.74192 & 0.10654 & 0.10531 \\
\hline 5014 & 447.911 & 450.330 & 50.0314 & 0.74180 & 0.10698 & 0.10574 \\
\hline 5015 & 447.919 & 450.575 & 50.0394 & 0.74168 & 0.10641 & 0.10517 \\
\hline 5016 & 447.906 & 449.729 & 41.2702 & 0.73404 & 0.10366 & 0.10239 \\
\hline 5017 & 447.904 & 449.937 & 41.2462 & 0.73390 & 0.10364 & 0.10237 \\
\hline 5018 & 447.911 & 450.166 & 41.2255 & 0.73375 & 0.10351 & 0.10223 \\
\hline 5019 & 447.919 & 450.409 & 41.2089 & 0.73360 & 0.10334 & 0.10206 \\
\hline 5020 & 447.907 & 450.637 & 41.2165 & 0.73348 & 0.10389 & 0.10260 \\
\hline 5021 & 447.889 & 449.755 & 34.3025 & 0.72703 & 0.10121 & 0.09991 \\
\hline 5022 & 447.895 & 449.974 & 34.3195 & 0.72691 & 0.10098 & 0.09968 \\
\hline 5023 & 447.899 & 450.200 & 34.3354 & 0.72680 & 0.10122 & 0.09991 \\
\hline 5024 & 447.923 & 450.468 & 34.3495 & 0.72665 & 0.10088 & 0.09957 \\
\hline
\end{tabular}


Table 10. Thermal conductivity of liquid RP-1.

\begin{tabular}{|c|c|c|c|c|c|c|}
\hline Point ID & $\begin{array}{c}T_{0} \\
(\mathbf{K})\end{array}$ & $\begin{array}{c}T_{\mathbf{e}} \\
(\mathbf{K})\end{array}$ & $\begin{array}{c}P_{\mathrm{e}} \\
(\mathbf{M P a})\end{array}$ & $\begin{array}{c}\rho_{\mathrm{e}} \\
\left(\mathrm{g} \cdot \mathrm{cm}^{-3}\right)\end{array}$ & $\begin{array}{c}\lambda_{\mathrm{e}} \\
\left(\mathbf{W} \cdot \mathbf{m}^{-1} \mathbf{K}^{-1}\right)\end{array}$ & $\begin{array}{c}\lambda_{\mathrm{c}} \\
\left(\mathbf{W} \cdot \mathbf{m}^{-1} \mathbf{K}^{-1}\right)\end{array}$ \\
\hline 5025 & 447.917 & 450.714 & 34.3608 & 0.72652 & 0.10087 & 0.09956 \\
\hline 5026 & 447.899 & 449.807 & 27.8189 & 0.71992 & 0.09862 & 0.09730 \\
\hline 5027 & 447.903 & 450.031 & 27.7971 & 0.71975 & 0.09845 & 0.09712 \\
\hline 5028 & 447.905 & 450.265 & 27.7795 & 0.71959 & 0.09856 & 0.09722 \\
\hline 5029 & 447.913 & 450.520 & 27.7664 & 0.71942 & 0.09853 & 0.09720 \\
\hline 5030 & 447.905 & 450.769 & 27.7621 & 0.71926 & 0.09835 & 0.09702 \\
\hline 5031 & 447.893 & 449.857 & 20.7169 & 0.71137 & 0.09580 & 0.09445 \\
\hline 5032 & 447.895 & 450.087 & 20.6985 & 0.71119 & 0.09573 & 0.09437 \\
\hline 5033 & 447.905 & 450.333 & 20.6836 & 0.71101 & 0.09554 & 0.09418 \\
\hline 5034 & 447.906 & 450.587 & 20.6850 & 0.71085 & 0.09550 & 0.09414 \\
\hline 5035 & 447.905 & 450.851 & 20.6988 & 0.71069 & 0.09536 & 0.09400 \\
\hline 5036 & 447.883 & 449.890 & 15.3503 & 0.70424 & 0.09352 & 0.09215 \\
\hline 5037 & 447.889 & 450.128 & 15.3608 & 0.70409 & 0.09326 & 0.09188 \\
\hline 5038 & 447.886 & 450.367 & 15.3694 & 0.70393 & 0.09370 & 0.09231 \\
\hline 5039 & 447.898 & 450.640 & 15.3777 & 0.70376 & 0.09316 & 0.09178 \\
\hline 5040 & 447.906 & 450.915 & 15.3851 & 0.70358 & 0.09306 & 0.09168 \\
\hline 5041 & 447.888 & 449.937 & 11.1635 & 0.69816 & 0.09158 & 0.09019 \\
\hline 5042 & 447.899 & 450.182 & 11.1639 & 0.69798 & 0.09154 & 0.09014 \\
\hline 5043 & 447.919 & 450.449 & 11.1449 & 0.69776 & 0.09142 & 0.09002 \\
\hline 5044 & 447.913 & 450.710 & 11.1238 & 0.69754 & 0.09136 & 0.08996 \\
\hline 5045 & 447.910 & 450.983 & 11.1067 & 0.69731 & 0.09121 & 0.08981 \\
\hline 5046 & 447.869 & 449.998 & 3.6297 & 0.68575 & 0.08778 & 0.08637 \\
\hline 5047 & 447.889 & 450.267 & 3.6382 & 0.68555 & 0.08785 & 0.08643 \\
\hline 5048 & 447.893 & 450.528 & 3.6454 & 0.68536 & 0.08783 & 0.08636 \\
\hline 5049 & 447.889 & 450.798 & 3.6525 & 0.68515 & 0.08771 & 0.08629 \\
\hline 5050 & 447.896 & 451.088 & 3.6577 & 0.68493 & 0.08764 & 0.08621 \\
\hline 5051 & 447.882 & 450.059 & 0.1765 & 0.67919 & 0.08582 & 0.08440 \\
\hline 5052 & 447.890 & 450.318 & 0.1697 & 0.67896 & 0.08591 & 0.08449 \\
\hline 5053 & 447.908 & 450.599 & 0.1764 & 0.67873 & 0.08576 & 0.08434 \\
\hline 5054 & 447.886 & 450.854 & 0.1878 & 0.67854 & 0.08579 & 0.08436 \\
\hline 5055 & 447.902 & 451.159 & 0.1979 & 0.67830 & 0.08562 & 0.08419 \\
\hline 6001 & 501.556 & 503.108 & 68.6557 & 0.73147 & 0.10791 & 0.10614 \\
\hline 6002 & 501.565 & 503.294 & 68.6482 & 0.73138 & 0.10802 & 0.10624 \\
\hline 6003 & 501.579 & 503.499 & 68.6109 & 0.73125 & 0.10790 & 0.10613 \\
\hline 6004 & 501.561 & 503.682 & 68.5784 & 0.73113 & 0.10766 & 0.10583 \\
\hline 6005 & 501.554 & 503.878 & 68.5536 & 0.73102 & 0.10773 & 0.10596 \\
\hline 6006 & 501.492 & 503.091 & 58.5297 & 0.72228 & 0.10462 & 0.10279 \\
\hline 6007 & 501.488 & 503.271 & 58.5390 & 0.72220 & 0.10456 & 0.10273 \\
\hline 6008 & 501.503 & 503.479 & 58.5461 & 0.72211 & 0.10454 & 0.10271 \\
\hline 6009 & 501.505 & 503.684 & 58.5529 & 0.72201 & 0.10442 & 0.10260 \\
\hline 6010 & 501.506 & 503.900 & 58.5550 & 0.72191 & 0.10465 & 0.10282 \\
\hline 6011 & 501.485 & 503.138 & 48.2361 & 0.71189 & 0.10097 & 0.09909 \\
\hline 6012 & 501.491 & 503.336 & 48.2135 & 0.71177 & 0.10086 & 0.09898 \\
\hline
\end{tabular}


Table 10. Thermal conductivity of liquid RP-1.

\begin{tabular}{|c|c|c|c|c|c|c|}
\hline Point ID & $\begin{array}{c}T_{0} \\
(\mathbf{K})\end{array}$ & $\begin{array}{c}T_{\mathbf{e}} \\
(\mathbf{K})\end{array}$ & $\begin{array}{c}P_{\mathrm{e}} \\
(\mathbf{M P a})\end{array}$ & $\begin{array}{c}\rho_{\mathrm{e}} \\
\left(\mathrm{g} \cdot \mathrm{cm}^{-3}\right)\end{array}$ & $\begin{array}{c}\lambda_{\mathrm{e}} \\
\left(\mathbf{W} \cdot \mathbf{m}^{-1} \mathbf{K}^{-1}\right)\end{array}$ & $\begin{array}{c}\lambda_{\mathrm{c}} \\
\left(\mathbf{W} \cdot \mathbf{m}^{-1} \mathbf{K}^{-1}\right)\end{array}$ \\
\hline 6013 & 501.500 & 503.542 & 48.1945 & 0.71164 & 0.10097 & 0.09909 \\
\hline 6014 & 501.493 & 503.749 & 48.1807 & 0.71151 & 0.10122 & 0.09933 \\
\hline 6015 & 501.487 & 503.966 & 48.1838 & 0.71140 & 0.10068 & 0.09885 \\
\hline 6016 & 501.454 & 503.160 & 39.1892 & 0.70169 & 0.09746 & 0.09555 \\
\hline 6017 & 501.471 & 503.375 & 39.1977 & 0.70158 & 0.09740 & 0.09548 \\
\hline 6018 & 501.486 & 503.596 & 39.2047 & 0.70146 & 0.09732 & 0.09540 \\
\hline 6019 & 501.497 & 503.826 & 39.2083 & 0.70134 & 0.09824 & 0.09629 \\
\hline 6020 & 501.480 & 504.039 & 39.2048 & 0.70121 & 0.09753 & 0.09560 \\
\hline 6021 & 501.469 & 503.232 & 30.9930 & 0.69126 & 0.09424 & 0.09228 \\
\hline 6022 & 501.475 & 503.441 & 30.9816 & 0.69112 & 0.09405 & 0.09209 \\
\hline 6023 & 501.475 & 503.657 & 30.9862 & 0.69099 & 0.09419 & 0.09222 \\
\hline 6024 & 501.488 & 503.893 & 31.0013 & 0.69087 & 0.09454 & 0.09221 \\
\hline 6025 & 501.501 & 504.142 & 31.0161 & 0.69074 & 0.09428 & 0.09231 \\
\hline 6026 & 501.470 & 503.297 & 22.7998 & 0.67936 & 0.09099 & 0.08900 \\
\hline 6027 & 501.487 & 503.526 & 22.8038 & 0.67921 & 0.09060 & 0.08861 \\
\hline 6028 & 501.493 & 503.753 & 22.8028 & 0.67906 & 0.09078 & 0.08879 \\
\hline 6029 & 501.506 & 504.000 & 22.7819 & 0.67887 & 0.09059 & 0.08859 \\
\hline 6030 & 501.516 & 504.254 & 22.7625 & 0.67868 & 0.09053 & 0.08853 \\
\hline 6031 & 501.487 & 503.385 & 15.4641 & 0.66692 & 0.08729 & 0.08528 \\
\hline 6032 & 501.492 & 503.609 & 15.4503 & 0.66673 & 0.08721 & 0.08520 \\
\hline 6033 & 501.506 & 503.854 & 15.4406 & 0.66654 & 0.08713 & 0.08511 \\
\hline 6034 & 501.506 & 504.098 & 15.4385 & 0.66636 & 0.08710 & 0.08508 \\
\hline 6035 & 501.507 & 504.354 & 15.4490 & 0.66620 & 0.08701 & 0.08499 \\
\hline 6036 & 501.489 & 503.429 & 11.7229 & 0.65968 & 0.08549 & 0.08347 \\
\hline 6037 & 501.498 & 503.660 & 11.7341 & 0.65953 & 0.08525 & 0.08323 \\
\hline 6038 & 501.497 & 503.893 & 11.7437 & 0.65937 & 0.08523 & 0.08321 \\
\hline 6039 & 501.488 & 504.135 & 11.7521 & 0.65921 & 0.08519 & 0.08317 \\
\hline 6040 & 501.506 & 504.407 & 11.7591 & 0.65902 & 0.08511 & 0.08309 \\
\hline 6041 & 501.473 & 503.483 & 5.7558 & 0.64636 & 0.08228 & 0.08025 \\
\hline 6042 & 501.484 & 503.723 & 5.7489 & 0.64614 & 0.08216 & 0.08013 \\
\hline 6043 & 501.475 & 503.961 & 5.7334 & 0.64590 & 0.08198 & 0.07995 \\
\hline 6044 & 501.501 & 504.244 & 5.7211 & 0.64563 & 0.08196 & 0.08021 \\
\hline 6045 & 501.499 & 504.508 & 5.7106 & 0.64538 & 0.08188 & 0.07984 \\
\hline 6046 & 501.489 & 503.584 & 0.2293 & 0.63093 & 0.07857 & 0.07654 \\
\hline 6047 & 501.497 & 503.834 & 0.2292 & 0.63069 & 0.07857 & 0.07654 \\
\hline 6048 & 501.482 & 504.069 & 0.2293 & 0.63046 & 0.07858 & 0.07655 \\
\hline 6049 & 501.500 & 504.352 & 0.2300 & 0.63019 & 0.07857 & 0.07653 \\
\hline 6050 & 501.482 & 504.618 & 0.2307 & 0.62993 & 0.07834 & 0.07630 \\
\hline 6051 & 501.361 & 503.455 & 0.2316 & 0.63107 & 0.07865 & 0.07663 \\
\hline 6052 & 501.373 & 503.707 & 0.2319 & 0.63082 & 0.07862 & 0.07659 \\
\hline 6053 & 501.380 & 503.969 & 0.2321 & 0.63057 & 0.07857 & 0.07654 \\
\hline 6054 & 501.361 & 504.216 & 0.2322 & 0.63033 & 0.07861 & 0.07657 \\
\hline 6055 & 501.365 & 504.503 & 0.2324 & 0.63005 & 0.07850 & 0.07646 \\
\hline
\end{tabular}


Table 10. Thermal conductivity of liquid RP-1.

\begin{tabular}{|c|c|c|c|c|c|c|}
\hline Point ID & $\begin{array}{c}T_{0} \\
(\mathbf{K})\end{array}$ & $\begin{array}{c}T_{\mathbf{e}} \\
(\mathbf{K})\end{array}$ & $\begin{array}{c}P_{\mathrm{e}} \\
(\mathrm{MPa})\end{array}$ & $\begin{array}{c}\rho_{\mathrm{e}} \\
\left(\mathrm{g} \cdot \mathrm{cm}^{-3}\right)\end{array}$ & $\begin{array}{c}\lambda_{\mathrm{e}} \\
\left(\mathbf{W} \cdot \mathbf{m}^{-1} \mathbf{K}^{-1}\right)\end{array}$ & $\begin{array}{c}\lambda_{\mathrm{c}} \\
\left(\mathbf{W} \cdot \mathbf{m}^{-1} \mathbf{K}^{-1}\right)\end{array}$ \\
\hline 7001 & 545.383 & 546.851 & 67.4191 & 0.70986 & 0.10481 & 0.10239 \\
\hline 7002 & 545.381 & 547.018 & 67.4082 & 0.70977 & 0.10458 & 0.10217 \\
\hline 7003 & 545.381 & 547.197 & 67.4029 & 0.70968 & 0.10478 & 0.10236 \\
\hline 7004 & 545.388 & 547.394 & 67.3987 & 0.70959 & 0.10451 & 0.10209 \\
\hline 7005 & 545.383 & 547.581 & 67.3945 & 0.70950 & 0.10451 & 0.10209 \\
\hline 7006 & 545.396 & 546.916 & 56.9830 & 0.69905 & 0.10122 & 0.09880 \\
\hline 7007 & 545.399 & 547.094 & 56.9839 & 0.69896 & 0.10133 & 0.09884 \\
\hline 7008 & 545.415 & 547.292 & 56.9840 & 0.69886 & 0.10130 & 0.09882 \\
\hline 7009 & 545.421 & 547.490 & 56.9823 & 0.69876 & 0.10119 & 0.09870 \\
\hline 7010 & 545.424 & 547.695 & 56.9813 & 0.69866 & 0.10093 & 0.09845 \\
\hline 7011 & 545.430 & 546.986 & 50.3613 & 0.69148 & 0.09904 & 0.09652 \\
\hline 7012 & 545.456 & 547.191 & 50.3670 & 0.69138 & 0.09868 & 0.09617 \\
\hline 7013 & 545.449 & 547.372 & 50.3813 & 0.69131 & 0.09868 & 0.09617 \\
\hline 7014 & 545.452 & 547.570 & 50.3948 & 0.69122 & 0.09849 & 0.09597 \\
\hline 7015 & 545.465 & 547.792 & 50.4064 & 0.69112 & 0.09848 & 0.09596 \\
\hline 7016 & 545.436 & 547.031 & 43.2920 & 0.68268 & 0.09594 & 0.09340 \\
\hline 7017 & 545.441 & 547.220 & 43.2966 & 0.68258 & 0.09597 & 0.09342 \\
\hline 7018 & 545.459 & 547.431 & 43.2993 & 0.68247 & 0.09606 & 0.09351 \\
\hline 7019 & 545.453 & 547.630 & 43.2938 & 0.68236 & 0.09583 & 0.09328 \\
\hline 7020 & 545.467 & 547.860 & 43.2682 & 0.68220 & 0.09572 & 0.09316 \\
\hline 7021 & 545.442 & 547.089 & 36.1910 & 0.67288 & 0.09311 & 0.09053 \\
\hline 7022 & 545.438 & 547.270 & 36.1943 & 0.67278 & 0.09306 & 0.09048 \\
\hline 7023 & 545.459 & 547.493 & 36.1931 & 0.67265 & 0.09311 & 0.09053 \\
\hline 7024 & 545.476 & 547.716 & 36.1896 & 0.67252 & 0.09302 & 0.09043 \\
\hline 7025 & 545.475 & 547.936 & 36.1673 & 0.67236 & 0.09310 & 0.09051 \\
\hline 7026 & 545.426 & 547.138 & 27.3687 & 0.65893 & 0.08951 & 0.08689 \\
\hline 7027 & 545.457 & 547.363 & 27.3756 & 0.65880 & 0.08939 & 0.08677 \\
\hline 7028 & 545.461 & 547.573 & 27.3780 & 0.65867 & 0.08948 & 0.08685 \\
\hline 7029 & 545.461 & 547.790 & 27.3805 & 0.65854 & 0.08949 & 0.08686 \\
\hline 7030 & 545.451 & 548.008 & 27.3644 & 0.65838 & 0.08935 & 0.08672 \\
\hline 7031 & 545.426 & 547.197 & 20.5868 & 0.64631 & 0.08607 & 0.08344 \\
\hline 7032 & 545.435 & 547.411 & 20.5896 & 0.64617 & 0.08596 & 0.08333 \\
\hline 7033 & 545.445 & 547.635 & 20.5911 & 0.64602 & 0.08623 & 0.08359 \\
\hline 7034 & 545.458 & 547.874 & 20.5770 & 0.64583 & 0.08622 & 0.08357 \\
\hline 7035 & 545.464 & 548.116 & 20.5600 & 0.64563 & 0.08582 & 0.08318 \\
\hline 7036 & 545.430 & 547.256 & 14.7485 & 0.63351 & 0.08344 & 0.08078 \\
\hline 7037 & 545.419 & 547.460 & 14.7549 & 0.63337 & 0.08307 & 0.08042 \\
\hline 7038 & 545.421 & 547.681 & 14.7604 & 0.63322 & 0.08312 & 0.08047 \\
\hline 7039 & 545.443 & 547.939 & 14.7656 & 0.63304 & 0.08298 & 0.08033 \\
\hline 7040 & 545.454 & 548.197 & 14.7698 & 0.63286 & 0.08289 & 0.08024 \\
\hline 7041 & 545.420 & 547.317 & 9.6654 & 0.62017 & 0.08041 & 0.07776 \\
\hline 7042 & 545.436 & 547.555 & 9.6709 & 0.61999 & 0.08001 & 0.07736 \\
\hline 7043 & 545.429 & 547.775 & 9.6760 & 0.61982 & 0.08008 & 0.07743 \\
\hline
\end{tabular}


Table 10. Thermal conductivity of liquid RP-1.

\begin{tabular}{|c|c|c|c|c|c|c|}
\hline Point ID & $\begin{array}{c}T_{0} \\
(\mathbf{K})\end{array}$ & $\begin{array}{c}T_{\mathbf{e}} \\
(\mathbf{K})\end{array}$ & $\begin{array}{c}P_{\mathrm{e}} \\
(\mathbf{M P a})\end{array}$ & $\begin{array}{c}\rho_{\mathrm{e}} \\
\left(\mathrm{g} \cdot \mathrm{cm}^{-3}\right)\end{array}$ & $\begin{array}{c}\lambda_{\mathrm{e}} \\
\left(\mathbf{W} \cdot \mathbf{m}^{-1} \mathbf{K}^{-1}\right)\end{array}$ & $\begin{array}{c}\lambda_{\mathrm{c}} \\
\left(\mathbf{W} \cdot \mathbf{m}^{-1} \mathbf{K}^{-1}\right)\end{array}$ \\
\hline 7044 & 545.443 & 548.028 & 9.6803 & 0.61962 & 0.08002 & 0.07737 \\
\hline 7045 & 545.431 & 548.272 & 9.6840 & 0.61943 & 0.07993 & 0.07728 \\
\hline 7046 & 545.426 & 547.321 & 9.6400 & 0.62009 & 0.08019 & 0.07754 \\
\hline 7047 & 545.444 & 547.557 & 9.6388 & 0.61989 & 0.08005 & 0.07741 \\
\hline 7048 & 545.450 & 547.789 & 9.6465 & 0.61972 & 0.08001 & 0.07736 \\
\hline 7049 & 545.441 & 548.021 & 9.6550 & 0.61955 & 0.07992 & 0.07727 \\
\hline 7050 & 545.443 & 548.279 & 9.6619 & 0.61936 & 0.07996 & 0.07731 \\
\hline 7051 & 545.412 & 547.356 & 6.0392 & 0.60874 & 0.07802 & 0.07537 \\
\hline 7052 & 545.410 & 547.578 & 6.0433 & 0.60855 & 0.07787 & 0.07523 \\
\hline 7053 & 545.435 & 547.836 & 6.0470 & 0.60832 & 0.07782 & 0.07518 \\
\hline 7054 & 545.447 & 548.093 & 6.0494 & 0.60810 & 0.07781 & 0.07516 \\
\hline 7055 & 545.437 & 548.348 & 6.0515 & 0.60787 & 0.07772 & 0.07507 \\
\hline 7056 & 545.420 & 547.422 & 2.8458 & 0.59656 & 0.07562 & 0.07300 \\
\hline 7057 & 545.406 & 547.635 & 2.8430 & 0.59633 & 0.07567 & 0.07304 \\
\hline 7058 & 545.436 & 547.907 & 2.8335 & 0.59601 & 0.07563 & 0.07300 \\
\hline 7059 & 545.426 & 548.151 & 2.8249 & 0.59572 & 0.07552 & 0.07289 \\
\hline 7060 & 545.435 & 548.429 & 2.8180 & 0.59541 & 0.07561 & 0.07297 \\
\hline 7061 & 544.931 & 546.966 & 1.0907 & 0.58916 & 0.07449 & 0.07188 \\
\hline 7062 & 544.952 & 547.222 & 1.0966 & 0.58891 & 0.07427 & 0.07167 \\
\hline 7063 & 544.962 & 547.477 & 1.1018 & 0.58864 & 0.07425 & 0.07164 \\
\hline 7064 & 544.946 & 547.716 & 1.1060 & 0.58840 & 0.07416 & 0.07155 \\
\hline 7065 & 544.966 & 548.006 & 1.1101 & 0.58809 & 0.07411 & 0.07150 \\
\hline 8001 & 605.887 & 608.009 & 15.0088 & 0.58786 & 0.08163 & 0.07782 \\
\hline 8002 & 605.896 & 608.232 & 15.0091 & 0.58769 & 0.08181 & 0.07800 \\
\hline 8003 & 605.889 & 608.454 & 15.0098 & 0.58751 & 0.08170 & 0.07789 \\
\hline 8004 & 605.885 & 608.687 & 15.0109 & 0.58733 & 0.08183 & 0.07800 \\
\hline 8005 & 605.901 & 608.954 & 15.0124 & 0.58713 & 0.08171 & 0.07788 \\
\hline 8006 & 605.901 & 607.571 & 68.9229 & 0.68401 & 0.10529 & 0.10169 \\
\hline 8007 & 605.902 & 607.754 & 68.9080 & 0.68391 & 0.10525 & 0.10165 \\
\hline 8008 & 605.908 & 607.937 & 68.9000 & 0.68382 & 0.10510 & 0.10151 \\
\hline 8009 & 605.907 & 608.117 & 68.9029 & 0.68375 & 0.10520 & 0.10160 \\
\hline 8010 & 605.919 & 608.329 & 68.9171 & 0.68367 & 0.10508 & 0.10147 \\
\hline 8011 & 605.970 & 607.725 & 54.3640 & 0.66635 & 0.10000 & 0.09631 \\
\hline 8012 & 605.986 & 607.920 & 54.3665 & 0.66626 & 0.09978 & 0.09610 \\
\hline 8013 & 605.988 & 608.114 & 54.3508 & 0.66614 & 0.09956 & 0.09588 \\
\hline 8014 & 606.003 & 608.325 & 54.3318 & 0.66602 & 0.09998 & 0.09592 \\
\hline 8015 & 606.015 & 608.541 & 54.3142 & 0.66589 & 0.09958 & 0.09588 \\
\hline 8016 & 605.989 & 607.838 & 41.3265 & 0.64724 & 0.09465 & 0.09090 \\
\hline 8017 & 605.993 & 608.034 & 41.3139 & 0.64711 & 0.09458 & 0.09082 \\
\hline 8018 & 606.000 & 608.237 & 41.3159 & 0.64701 & 0.09446 & 0.09071 \\
\hline 8019 & 606.011 & 608.454 & 41.3281 & 0.64691 & 0.09431 & 0.09056 \\
\hline 8020 & 606.012 & 608.674 & 41.3388 & 0.64681 & 0.09443 & 0.09067 \\
\hline 8021 & 605.989 & 607.926 & 30.8369 & 0.62830 & 0.08999 & 0.08619 \\
\hline
\end{tabular}


Table 10. Thermal conductivity of liquid RP-1.

\begin{tabular}{|c|c|c|c|c|c|c|}
\hline Point ID & $\begin{array}{c}T_{0} \\
(\mathbf{K})\end{array}$ & $\begin{array}{c}T_{\mathbf{e}} \\
(\mathbf{K})\end{array}$ & $\begin{array}{c}P_{\mathrm{e}} \\
(\mathbf{M P a})\end{array}$ & $\begin{array}{c}\rho_{\mathrm{e}} \\
\left(\mathrm{g} \cdot \mathrm{cm}^{-3}\right)\end{array}$ & $\begin{array}{c}\lambda_{\mathrm{e}} \\
\left(\mathbf{W} \cdot \mathbf{m}^{-1} \mathbf{K}^{-1}\right)\end{array}$ & $\begin{array}{c}\lambda_{\mathrm{c}} \\
\left(\mathbf{W} \cdot \mathbf{m}^{-1} \mathbf{K}^{-1}\right)\end{array}$ \\
\hline 8022 & 605.992 & 608.130 & 30.8407 & 0.62819 & 0.08988 & 0.08609 \\
\hline 8023 & 605.990 & 608.336 & 30.8421 & 0.62807 & 0.08997 & 0.08617 \\
\hline 8024 & 606.013 & 608.574 & 30.8294 & 0.62790 & 0.08990 & 0.08609 \\
\hline 8025 & 606.003 & 608.792 & 30.8140 & 0.62774 & 0.08990 & 0.08609 \\
\hline 8026 & 605.958 & 607.983 & 22.9257 & 0.61062 & 0.08607 & 0.08226 \\
\hline 8027 & 605.969 & 608.201 & 22.9273 & 0.61048 & 0.08601 & 0.08220 \\
\hline 8028 & 605.985 & 608.430 & 22.9169 & 0.61030 & 0.08592 & 0.08211 \\
\hline 8029 & 606.005 & 608.681 & 22.9027 & 0.61010 & 0.08573 & 0.08192 \\
\hline 8030 & 606.010 & 608.922 & 22.8928 & 0.60991 & 0.08586 & 0.08204 \\
\hline 8031 & 605.986 & 608.109 & 15.2320 & 0.58853 & 0.08187 & 0.07806 \\
\hline 8032 & 605.986 & 608.326 & 15.2214 & 0.58832 & 0.08187 & 0.07805 \\
\hline 8033 & 605.996 & 608.564 & 15.2123 & 0.58811 & 0.08167 & 0.07785 \\
\hline 8034 & 606.009 & 608.814 & 15.2060 & 0.58789 & 0.08165 & 0.07783 \\
\hline 8035 & 606.007 & 609.062 & 15.2004 & 0.58768 & 0.08166 & 0.07783 \\
\hline 8036 & 605.901 & 608.103 & 10.2436 & 0.56965 & 0.07862 & 0.07483 \\
\hline 8037 & 605.927 & 608.356 & 10.2371 & 0.56939 & 0.07862 & 0.07482 \\
\hline 8038 & 605.918 & 608.579 & 10.2284 & 0.56915 & 0.07841 & 0.07462 \\
\hline 8039 & 605.931 & 608.846 & 10.2215 & 0.56888 & 0.07834 & 0.07455 \\
\hline 8040 & 605.961 & 609.137 & 10.2159 & 0.56859 & 0.07840 & 0.07459 \\
\hline 8041 & 605.890 & 608.158 & 6.9713 & 0.55351 & 0.07621 & 0.07245 \\
\hline 8042 & 605.923 & 608.426 & 6.9734 & 0.55324 & 0.07619 & 0.07242 \\
\hline 8043 & 605.937 & 608.680 & 6.9744 & 0.55298 & 0.07616 & 0.07239 \\
\hline 8044 & 605.936 & 608.936 & 6.9695 & 0.55269 & 0.07625 & 0.07247 \\
\hline 8045 & 605.944 & 609.210 & 6.9636 & 0.55237 & 0.07608 & 0.07230 \\
\hline 8046 & 605.898 & 608.242 & 4.1257 & 0.53490 & 0.07371 & 0.07000 \\
\hline 8047 & 605.903 & 608.483 & 4.1296 & 0.53463 & 0.07451 & 0.07076 \\
\hline 8048 & 605.907 & 608.736 & 4.1333 & 0.53434 & 0.07388 & 0.07016 \\
\hline 8049 & 605.881 & 608.974 & 4.1364 & 0.53406 & 0.07380 & 0.07007 \\
\hline 8050 & 605.915 & 609.279 & 4.1394 & 0.53370 & 0.07371 & 0.06998 \\
\hline 8051 & 605.854 & 608.251 & 2.1312 & 0.51694 & 0.07215 & 0.06849 \\
\hline 8052 & 605.878 & 608.520 & 2.1330 & 0.51655 & 0.07215 & 0.06849 \\
\hline 8053 & 605.885 & 608.783 & 2.1344 & 0.51616 & 0.07198 & 0.06832 \\
\hline 8054 & 605.881 & 609.047 & 2.1350 & 0.51575 & 0.07183 & 0.06817 \\
\hline 8055 & 605.889 & 609.336 & 2.1321 & 0.51527 & 0.07174 & 0.06809 \\
\hline 8056 & 605.824 & 608.259 & 1.1099 & 0.50456 & 0.07062 & 0.06705 \\
\hline 8057 & 605.825 & 608.509 & 1.1098 & 0.50411 & 0.07066 & 0.06708 \\
\hline 8058 & 605.858 & 608.804 & 1.1085 & 0.50355 & 0.07060 & 0.06701 \\
\hline 8059 & 605.832 & 609.047 & 1.1080 & 0.50310 & 0.07092 & 0.06731 \\
\hline 8060 & 605.839 & 609.340 & 1.1078 & 0.50256 & 0.07090 & 0.06729 \\
\hline 9006 & 647.900 & 649.976 & 12.5113 & 0.54280 & 0.07897 & 0.07423 \\
\hline 9007 & 647.882 & 650.176 & 12.5159 & 0.54265 & 0.07885 & 0.07411 \\
\hline 9008 & 647.875 & 650.394 & 12.5162 & 0.54246 & 0.07873 & 0.07400 \\
\hline 9009 & 647.888 & 650.643 & 12.5153 & 0.54223 & 0.07871 & 0.07398 \\
\hline
\end{tabular}


Table 10. Thermal conductivity of liquid RP-1.

\begin{tabular}{|c|c|c|c|c|c|c|}
\hline Point ID & $\begin{array}{c}T_{0} \\
(\mathbf{K})\end{array}$ & $\begin{array}{c}T_{\mathbf{e}} \\
(\mathbf{K})\end{array}$ & $\begin{array}{c}P_{\mathrm{e}} \\
(\mathbf{M P a})\end{array}$ & $\begin{array}{c}\rho_{\mathrm{e}} \\
\left(\mathrm{g} \cdot \mathrm{cm}^{-3}\right)\end{array}$ & $\begin{array}{c}\lambda_{\mathrm{e}} \\
\left(\mathbf{W} \cdot \mathbf{m}^{-1} \mathbf{K}^{-1}\right)\end{array}$ & $\begin{array}{c}\lambda_{\mathrm{c}} \\
\left(\mathbf{W} \cdot \mathbf{m}^{-1} \mathbf{K}^{-1}\right)\end{array}$ \\
\hline 9010 & 647.862 & 650.862 & 12.5150 & 0.54204 & 0.07855 & 0.07381 \\
\hline 9011 & 647.288 & 648.869 & 68.7755 & 0.66590 & 0.10489 & 0.10039 \\
\hline 9012 & 647.299 & 649.038 & 68.7679 & 0.66582 & 0.10444 & 0.09990 \\
\hline 9013 & 647.277 & 649.189 & 68.7776 & 0.66577 & 0.10447 & 0.09998 \\
\hline 9014 & 647.275 & 649.365 & 68.7887 & 0.66570 & 0.10432 & 0.09977 \\
\hline 9015 & 647.279 & 649.550 & 68.7983 & 0.66564 & 0.10469 & 0.10013 \\
\hline 9016 & 647.084 & 648.793 & 47.5140 & 0.63622 & 0.09659 & 0.09192 \\
\hline 9017 & 647.119 & 649.006 & 47.5050 & 0.63610 & 0.09648 & 0.09180 \\
\hline 9018 & 647.120 & 649.193 & 47.4964 & 0.63599 & 0.09610 & 0.09144 \\
\hline 9019 & 647.125 & 649.390 & 47.4906 & 0.63588 & 0.09630 & 0.09162 \\
\hline 9020 & 647.138 & 649.601 & 47.4928 & 0.63578 & 0.09612 & 0.09145 \\
\hline 9021 & 646.936 & 648.790 & 30.9474 & 0.60426 & 0.08905 & 0.08433 \\
\hline 9022 & 646.946 & 648.983 & 30.9604 & 0.60417 & 0.08922 & 0.08448 \\
\hline 9023 & 646.931 & 649.165 & 30.9726 & 0.60410 & 0.08918 & 0.08444 \\
\hline 9024 & 646.923 & 649.366 & 30.9838 & 0.60400 & 0.08903 & 0.08429 \\
\hline 9025 & 646.936 & 649.599 & 30.9946 & 0.60389 & 0.08906 & 0.08431 \\
\hline 9026 & 646.823 & 648.804 & 19.8446 & 0.57356 & 0.08326 & 0.07853 \\
\hline 9027 & 646.825 & 649.005 & 19.8431 & 0.57341 & 0.08343 & 0.07869 \\
\hline 9028 & 646.832 & 649.225 & 19.8429 & 0.57326 & 0.08322 & 0.07848 \\
\hline 9029 & 646.832 & 649.447 & 19.8457 & 0.57311 & 0.08314 & 0.07841 \\
\hline 9030 & 646.839 & 649.688 & 19.8528 & 0.57296 & 0.08307 & 0.07834 \\
\hline 9031 & 646.565 & 648.662 & 12.4149 & 0.54348 & 0.07850 & 0.07382 \\
\hline 9032 & 646.581 & 648.893 & 12.4166 & 0.54328 & 0.07853 & 0.07385 \\
\hline 9033 & 646.586 & 649.124 & 12.4191 & 0.54309 & 0.07844 & 0.07375 \\
\hline 9034 & 646.575 & 649.349 & 12.4242 & 0.54292 & 0.07845 & 0.07376 \\
\hline 9035 & 646.551 & 649.569 & 12.4331 & 0.54277 & 0.07843 & 0.07374 \\
\hline 9036 & 646.212 & 648.432 & 7.3542 & 0.51194 & 0.07428 & 0.06971 \\
\hline 9037 & 646.207 & 648.654 & 7.3563 & 0.51170 & 0.07453 & 0.07018 \\
\hline 9038 & 646.206 & 648.890 & 7.3593 & 0.51145 & 0.07435 & 0.06978 \\
\hline 9039 & 646.211 & 649.144 & 7.3632 & 0.51119 & 0.07437 & 0.06978 \\
\hline 9040 & 646.201 & 649.394 & 7.3687 & 0.51095 & 0.07437 & 0.06978 \\
\hline 9041 & 645.805 & 648.101 & 4.6461 & 0.48546 & 0.07235 & 0.06785 \\
\hline 9042 & 645.818 & 648.348 & 4.6503 & 0.48514 & 0.07242 & 0.06791 \\
\hline 9043 & 645.846 & 648.627 & 4.6544 & 0.48477 & 0.07227 & 0.06777 \\
\hline 9044 & 645.856 & 648.894 & 4.6581 & 0.48442 & 0.07234 & 0.06783 \\
\hline 9045 & 645.875 & 649.180 & 4.6613 & 0.48403 & 0.07284 & 0.06828 \\
\hline
\end{tabular}




\section{Viscosity}

\subsection{Viscosity at Atmospheric Pressure}

The kinematic viscosities $(v)$ of the RP-1 samples were measured at atmospheric pressure (approximately $83 \mathrm{kPa}$ ) by open gravitational capillary viscometry. With this technique, the time $(t)$ required for a given volume of the liquid to flow through a calibrated capillary under the influence of gravity was measured. The flow time is proportional to the kinematic viscosity:

$$
v=C \cdot t
$$

where the proportionality constant, $C$, is determined by calibrating the capillary with standard reference liquids. The absolute viscosity $(\eta)$ can be determined from the kinematic viscosity if the density $(\rho)$ of the liquid is known:

$$
\eta=v \cdot \rho
$$

For these measurements we used the procedure outlined in ASTM method D 445 - 03; however, instead of averaging two determinations of the kinematic viscosity, at least eight determinations were averaged for each entry in Table 11. Commercially obtained Ubbelohde capillary viscometers were used for all the measurements. The capillary viscometers were calibrated at NIST using commercially obtained standard reference liquids. The calibration constant, $C$, for each capillary was found to be within the stated uncertainty of the manufacturer's calibration constant. During a measurement, the viscometers were immersed in an insulated, continuously stirred bath (ethylene glycol + water) whose temperature was maintained with a refrigerated circulator, an electric heater, and a precision temperature controller. The bath temperature was measured with an ITS-90 calibrated platinum resistance thermometer accurate to $\pm 0.01 \mathrm{~K}$. Flow times were measured automatically. 
With this apparatus, the expanded uncertainty in the kinematic viscosity is estimated to be $1 \%(\mathrm{k}=2)$. The primary contribution to the uncertainty is the $0.5 \%$ standard uncertainty in $C$, which results in a $0.5 \%$ standard uncertainty in the kinematic viscosity. Including fluctuations and temperature gradients, the uncertainty in the temperature is estimated to be $0.02 \mathrm{~K}$, which leads to a negligible standard uncertainty in the kinematic viscosity of $\leq 0.074 \%$. The Hagenbach (kinetic energy) correction was $\leq 0.13 \%$, so it was also neglected. The uncertainty in the flow time measurement also leads to a negligible standard uncertainty of about $0.01 \%$ in the kinematic viscosity. Since the RP-1 samples are hydrocarbon-based, no correction was necessary to account for the difference in surface tension between the hydrocarbon-based calibration liquids and the test samples.

Kinematic viscosities were measured as a function of temperature for four RP-1 samples. The first sample was the original sample of RP-1 (acquired May 2003, designated by batch number P000016660,) which has anomalously high olefin (unsaturated hydrocarbon) content. Viscosities were measured from $243.29 \mathrm{~K}$ to $333.15 \mathrm{~K}$ (approximately $-30{ }^{\circ} \mathrm{C}$ to $60{ }^{\circ} \mathrm{C}$ ). The kinematic viscosities of the other three samples - a second sample of normal grade RP-1 (acquired November 2004, designated 11/03), an ultra-low sulfur RP-1 (batch number not provided), and a TS-5 RP-1 (batch number not provided) — were measured only at $298.15 \mathrm{~K}\left(25^{\circ} \mathrm{C}\right)$ and $313.15 \mathrm{~K}$ $\left(40^{\circ} \mathrm{C}\right)$. All of these data are collected in Table 11 . At some temperatures the kinematic viscosity of the original sample of RP-1 was determined multiple times using different aliquots of that sample. Such independent determinations are listed separately in Table 11.

Figure 7(a) shows a graph of the kinematic viscosity as a function of temperature for the original sample of RP-1. Figure 7(b) shows an Arrhenius plot of the same data with a correlation to a modified Arrhenius equation of the form, 


$$
\ln (v)=\mathrm{A}+\mathrm{B}(1 / T)+\mathrm{C}(1 / T)^{2}+\mathrm{D}(1 / T)^{3},
$$

where A, B, C, and D are constants and $T$ is the temperature in kelvins. A regression analysis gave the following values for the coefficients: $\mathrm{A}=-7.812, \mathrm{~B}=5.530 \times 10^{3}, \mathrm{C}=-1.503 \times 10^{6}$, and $\mathrm{D}=$ $1.801 \times 10^{8}$. Figure $7(\mathrm{c})$ shows the percent deviation of the measured kinematic viscosities from the correlation given in Eq. (1). All of the data points are within $1.1 \%$ of Eq. (1).

Figure 8 shows the percent deviation of the kinematic viscosities of the three other rocket propellant samples compared to the correlation of the data for the original sample of RP-1, Eq. (1). The error bars in Figure 8 correspond to the repeatability of the measurements at the 2-sigma level, not to the total uncertainty in the measurement. Figure 8 shows that the viscosities for the second RP-1 sample, the TS-5 sample and the ultra-low sulfur sample are all about 7 to $10 \%$ higher than the correlation at $298.15 \mathrm{~K}$ and $313.15 \mathrm{~K}$. Hence, capillary viscosity measurements easily distinguish all three of these samples from the original sample of RP-1. The second RP-1 sample is also distinguishable from the TS-5 and the ultra-low sulfur samples. However, the viscosities of the TS-5 and the ultra-low sulfur samples cannot be distinguished with this apparatus.

These measurements show that the anomalous composition of the original sample of RP-1 results in a significant change in the viscosity behavior of that sample compared to a "normal" RP-1 sample whose composition is on specification. Consequently, these data provide strong motivation for additional measurements on a "normal" RP-1 sample. These measurements also show that the two low-sulfur versions of RP-1 are significantly different from normal grade RP-1. Hence, accurate models of such low-sulfur rocket propellants will require separate viscosity measurements. 
Table 11. Experimental kinematic viscosities ( $v$ ) for four RP-1 samples.

\begin{tabular}{|c|c|c|c|}
\hline & Temperature / K & $\boldsymbol{v} /\left(\mathrm{mm}^{2} \cdot \mathrm{s}^{-1}\right)$ & Capillary used \\
\hline $\begin{array}{r}\text { Original sample of RP-1 } \\
\text { (acquired 05/03, P000016660) }\end{array}$ & $\begin{array}{l}243.29 \\
243.93 \\
248.15 \\
248.16 \\
253.15 \\
258.15 \\
263.15 \\
263.15 \\
268.15 \\
273.15 \\
278.15 \\
283.15 \\
288.15 \\
288.15 \\
293.15 \\
293.15 \\
298.15 \\
298.15 \\
298.15 \\
298.15 \\
298.15 \\
298.15 \\
298.15 \\
303.15 \\
308.15 \\
313.15 \\
323.15 \\
333.15\end{array}$ & $\begin{array}{l}7.667 \\
7.431 \\
6.530 \\
6.368 \\
5.369 \\
4.601 \\
4.027 \\
3.990 \\
3.496 \\
3.093 \\
2.758 \\
2.479 \\
2.242 \\
2.255 \\
2.053 \\
2.040 \\
1.867 \\
1.870 \\
1.867 \\
1.875 \\
1.878 \\
1.880 \\
1.865 \\
1.723 \\
1.591 \\
1.475 \\
1.282 \\
1.126\end{array}$ & $\begin{array}{c}\mathrm{I}^{*} \\
\mathrm{I}^{*} \\
\mathrm{I} \\
\mathrm{I}^{*} \\
\mathrm{I} \\
\mathrm{I} \\
\mathrm{I} \\
\mathrm{I} \\
\mathrm{I} \\
\mathrm{I} \\
\mathrm{I} \\
\mathrm{I} \\
\mathrm{I} \\
0 \mathrm{~b} \\
0 \mathrm{~b} \\
\mathrm{I} \\
\mathrm{I} \\
\mathrm{I} \\
\mathrm{I} \\
0 \mathrm{~b} \\
0 \mathrm{~b} \\
0 \mathrm{~b} \\
\mathrm{I}^{*} \\
0 \mathrm{~b} \\
0 \mathrm{~b} \\
0 \mathrm{~b} \\
0 \mathrm{~b} \\
0 \mathrm{~b}\end{array}$ \\
\hline $\begin{array}{r}\text { Second sample of RP-1 } \\
\text { (acquired 11/03) }\end{array}$ & $\begin{array}{l}298.15 \\
313.15\end{array}$ & $\begin{array}{l}2.0214 \\
1.5768\end{array}$ & $\begin{array}{l}0 \mathrm{~b} \\
\mathrm{Ob}\end{array}$ \\
\hline Ultra-low sulfur RP-1 & $\begin{array}{l}298.15 \\
313.15\end{array}$ & $\begin{array}{l}2.0491 \\
1.5968\end{array}$ & $\begin{array}{l}0 \mathrm{~b} \\
\mathrm{Ob}\end{array}$ \\
\hline TS-5 RP-1 & $\begin{array}{l}298.15 \\
313.15\end{array}$ & $\begin{array}{l}2.0581 \\
1.6021\end{array}$ & $\begin{array}{l}\mathrm{Ob} \\
\mathrm{Ob}\end{array}$ \\
\hline
\end{tabular}

* These values were determined with a second capillary viscometer of size I. 

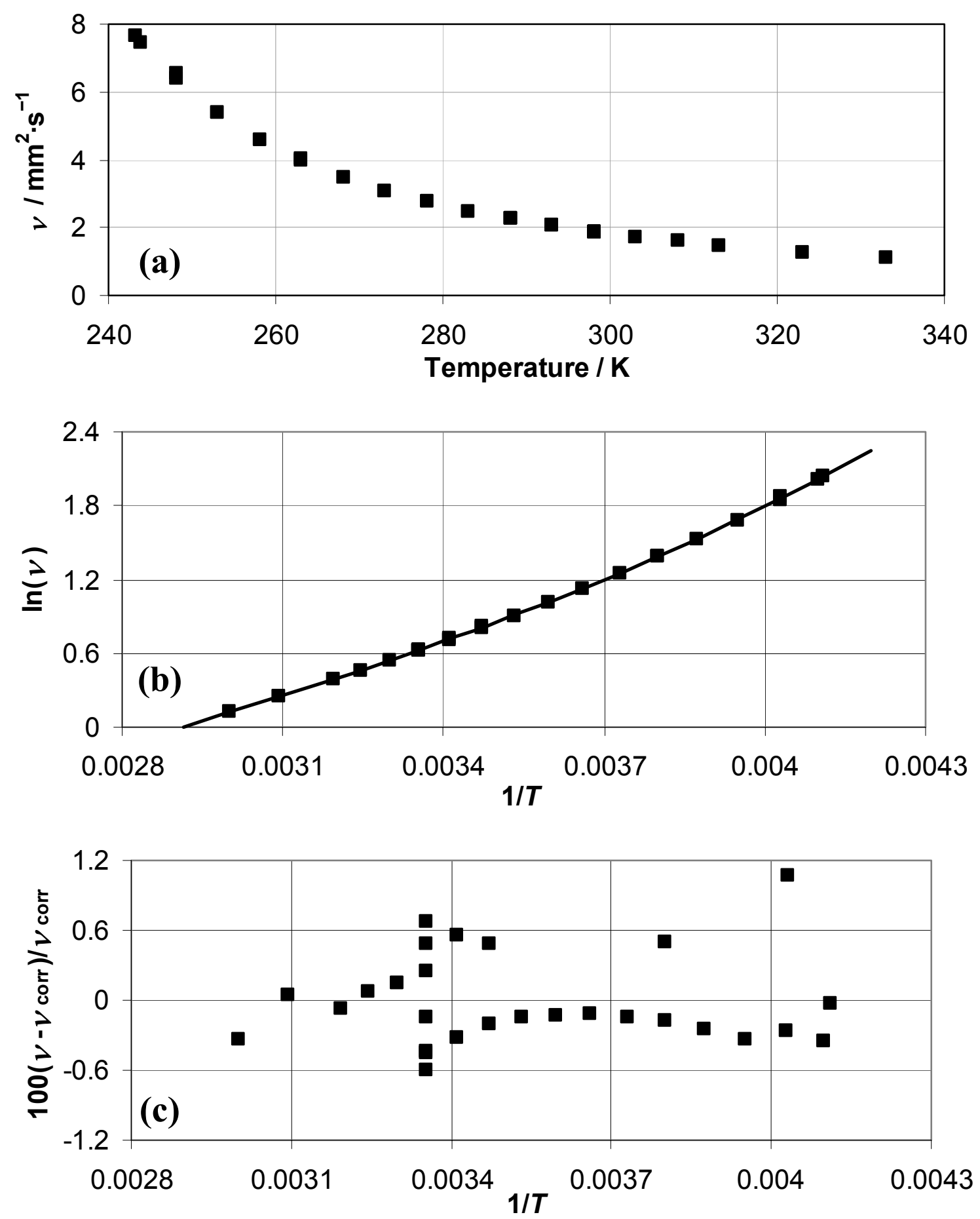

Figure 7. (a) Kinematic viscosity of the original sample of RP-1 as a function of temperature; (b) Arrhenius plot of the same data; solid curve is correlation; (c) deviations of kinematic viscosity from the correlation. 


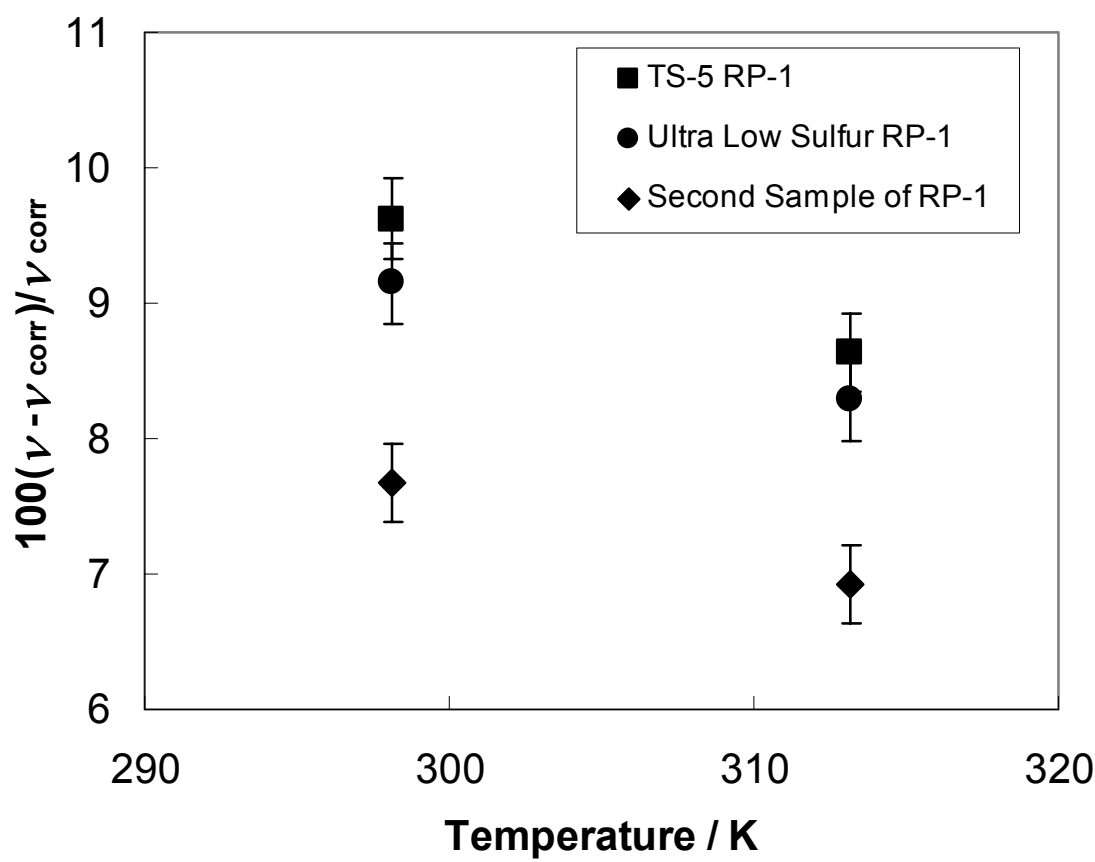

Figure 8. Percent deviations of the kinematic viscosities of three rocket propellant samples compared to the correlation of the kinematic viscosities for the original sample of RP-1.

\subsection{Viscosity at Elevated Pressures}

The viscosity of RP-1 kerosene was measured at elevated pressures up to $65.7 \mathrm{MPa}$ with a torsional crystal viscometer by mechanical spectroscopy in the frequency domain. Three isotherms were measured, two of which were near room temperature to validate the repeatability of the instrument, and one was at $400 \mathrm{~K}$. Table 12 presents the results of the measurements numerically, while the pressure dependence is shown in Figure 9.

Before introducing the sample fluid with a pressure generator, the viscometer was evacuated for three days. The internal damping of the torsional crystal transducer was measured in vacuo at room temperature prior to the RP-1 measurements. The transducer performance was consistent with the long-term results measured during the last decade. The pressure generator was cleaned with toluene and evacuated for $24 \mathrm{~h}$ before it was filled with RP-1. 
After charging the cell with RP-1, the quartz crystal viscosity transducer indicated no increase of the measured conductance. The susceptance rose by about 6 microsiemens $(\mu \mathrm{S})$ over its vacuum level. This is a typical increase for dense hydrocarbons. It is much lower than values observed with hydrofluorocarbons. These observations indicate the presence of no polar impurities in the sample fluid that might have caused electroviscous contributions in the measured viscosity data.

Each line in Table 12 represents an average of four measurements, except the line at 5.5 $\mathrm{MPa}$, which is based on only three measurements. The columns with the experimental data are followed by columns with their absolute and relative standard deviations. Included are columns with the averaged resonance frequencies $f^{*}$ and bandwidths $\Delta f$, which are the original experimental information. The product (viscosity $\times$ density) rather than the absolute viscosity is shown because measurements with this viscometer yield this product and the density needs to be supplied either from other measurements or from correlations or equations of state to obtain the viscosity. The pressure dependence of the measured (viscosity $\times$ density) results is illustrated in Figure 9.

The uncertainty of the pressure transducer is estimated at $0.01 \mathrm{MPa}$, while the uncertainty of the measured temperatures is estimated to be $0.05 \mathrm{~K}$. The typical uncertainty of the (viscosity $x$ density) results measured with this instrument is $2 \%$. However, the RP-1 measurements were conducted at the resolution limit of the impedance analyzer, so that higher uncertainties were incurred. These will be discussed below. The internal damping of the vibrating crystal was not accounted for in the data analysis at room temperature because the bandwidth in vacuo $(0.08 \mathrm{~Hz})$ is at most only $0.01 \%$ of the bandwidths of the resonances in the kerosene sample. The internal damping was included in the analysis of the data at $400 \mathrm{~K}$. 
Figure 10 compares the viscosities derived from Table 12 with viscosities calculated with the model that was developed in this project. The figure displays percent deviations of the experimental viscosities relative to those calculated with the model as a function of pressure. The deviations range between $-3.5 \%$ at $400 \mathrm{~K}$ and $0.1 \mathrm{MPa}$ and $-11.7 \%$ at $295 \mathrm{~K}$ and $41.5 \mathrm{MPa}$. Consequently, the model predicts higher viscosities than those measured. Given the complexity of the surrogate mixture, the agreement between the model and the measured data can be considered satisfactory. This is supported by a consideration of the uncertainties of the experimental data. They were assessed by calculating the change in the viscosity due to a change in the measured bandwidth $\Delta f$ resulting from the resolution of the impedance analyzer of $\pm 0.01 \mathrm{~Hz}$. The uncertainties are indicated in Figure 10 by horizontal bars above and below the data points at the highest and at the lowest pressure. The highest uncertainties of the viscosity data occur at the highest pressures due to the flatness of the resonance curves at high external damping of the torsionally vibrating crystal. While the measurement at the highest pressure of Series 2 at $296 \mathrm{~K}$ is $9.2 \%$ lower than the viscosity predicted by the model, the uncertainty of the measurement due to the impedance analyzer resolution of $\pm 0.1 \mathrm{~Hz}$ results in a deviation interval from $-15 \%$ to $-0.3 \%$. This puts the deviations between the experimental and the calculated model data in perspective.

\section{Bibliography for Viscosity}

Hafer, R. F.; Laesecke, A. Extension of the torsional crystal viscometer to measurements in the time domain. Meas. Sci. Technol. 14: 663-673 (2003).

Laesecke, A. Viscosity measurements and model comparisons for the refrigerant blends R-410A and R-507A. ASHRAE Trans. Symp. 110 (part 2): 503-521 (2004). 
Table 12. Results of viscosity measurements at elevated pressures.

\begin{tabular}{|c|c|c|c|c|c|c|c|c|}
\hline $\begin{array}{l}\boldsymbol{P}_{\text {exp }} \\
\mathrm{MPa}\end{array}$ & $\begin{array}{c}\boldsymbol{T}_{\exp } \\
\mathrm{K}\end{array}$ & $\begin{array}{l}f^{*} \\
\mathrm{~Hz}\end{array}$ & $\begin{array}{l}\mathbf{s}_{\mathrm{f}}{ }^{*} \\
\mathrm{~Hz}\end{array}$ & $\begin{array}{l}\Delta \boldsymbol{f} \\
\mathrm{Hz}\end{array}$ & $\begin{array}{l}\mathbf{s}_{\Delta \mathrm{f}} \\
\mathrm{Hz}\end{array}$ & $\underset{\mathrm{kg}^{2} \cdot \mathrm{m}^{-4} \cdot \mathrm{s}}{\boldsymbol{\eta} \times \boldsymbol{\rho}}$ & $\begin{array}{l}\mathbf{s}_{\eta \cdot \rho} \\
\mathrm{Hz}\end{array}$ & $\begin{array}{c}\mathbf{s}_{\eta} / \boldsymbol{\eta} \\
\%\end{array}$ \\
\hline 65.7032 & 295.23 & 39479.7920 & 1.5476 & 91.0156 & 0.8436 & 2.5287 & 0.047 & 1.85 \\
\hline 63.6221 & 295.37 & 39480.1843 & 1.8560 & 90.1313 & 2.0625 & 2.4804 & 0.115 & 4.62 \\
\hline 51.1380 & 295.57 & 39481.1876 & 1.0860 & 84.1500 & 0.7194 & 2.1606 & 0.037 & 1.71 \\
\hline 41.5231 & 295.68 & 39486.1139 & 1.2056 & 78.2529 & 0.6358 & 1.8676 & 0.030 & 1.63 \\
\hline 31.5127 & 295.78 & 39486.6795 & 0.6816 & 74.3371 & 1.1402 & 1.6851 & 0.052 & 3.07 \\
\hline 21.5319 & 295.91 & 39489.3690 & 1.0328 & 70.5069 & 0.2671 & 1.5151 & 0.011 & 0.76 \\
\hline 11.3880 & 297.23 & 39491.8394 & 0.6729 & 64.9280 & 0.0320 & 1.2843 & 0.001 & 0.10 \\
\hline 5.54529 & 297.22 & 39491.4181 & 0.9675 & 62.9383 & 0.3212 & 1.2066 & 0.012 & 1.02 \\
\hline 1.16686 & 297.30 & 39493.5601 & 0.3737 & 61.0921 & 0.8900 & 1.1368 & 0.033 & 2.91 \\
\hline 0.1190 & 297.31 & 39491.6728 & 0.6652 & 60.6646 & 0.4787 & 1.1209 & 0.018 & 1.58 \\
\hline 67.3416 & 296.12 & 39479.8022 & 2.7331 & 90.4688 & 0.8398 & 2.4985 & 0.046 & 1.86 \\
\hline 60.7903 & 296.22 & 39481.3354 & 2.1428 & 87.7083 & 0.4166 & 2.3477 & 0.022 & 0.95 \\
\hline 49.5042 & 296.27 & 39483.3182 & 0.8905 & 82.9125 & 1.1698 & 2.0974 & 0.059 & 2.83 \\
\hline 40.0488 & 297.12 & 39485.5269 & 1.4492 & 77.4432 & 0.6889 & 1.8290 & 0.032 & 1.77 \\
\hline 29.8420 & 297.14 & 39489.1896 & 1.5698 & 72.6040 & 0.2903 & 1.6069 & 0.013 & 0.80 \\
\hline 20.1337 & 297.25 & 39490.8163 & 0.9642 & 68.7578 & 0.92 & 1.4408 & 0.039 & 2.69 \\
\hline 10.1259 & 297.29 & 39490.7615 & 1.5726 & 64.4845 & 0.7253 & 1.2669 & 0.029 & 2.25 \\
\hline 5.0746 & 297.36 & 39490.9510 & 1.3958 & 62.7792 & 0.2912 & 1.2005 & 0.011 & 0.93 \\
\hline 1.2191 & 297.38 & 39493.5878 & 1.4182 & 61.1579 & 0.5500 & 1.1392 & 0.020 & 1.79 \\
\hline 0.1984 & 297.42 & 39493.9507 & 1.3361 & 60.6076 & 0.3710 & 1.1187 & 0.014 & 1.23 \\
\hline 68.1731 & 400.08 & 39508.6993 & & & & & & 1.01 \\
\hline 60.0641 & 400.06 & 39510.1366 & 0.6027 & 43.8570 & 0.3088 & 0.5842 & 0.008 & 1.41 \\
\hline 50.2712 & 400.07 & 39509.5068 & 0.6400 & 42.1027 & 0.1064 & 0.5383 & 0.003 & 0.50 \\
\hline 39.8690 & 400.04 & 39510.9737 & 0.5615 & 39.9416 & 0.2524 & 0.4843 & 0.006 & 1.26 \\
\hline 29.4055 & 400.06 & 39511.1211 & 0.2013 & 37.7958 & 0.1313 & 0.4335 & 0.003 & 0.69 \\
\hline 19.4202 & 400.06 & 39511.9547 & 0.2073 & 35.9434 & 0.2801 & 0.3919 & 0.006 & 1.56 \\
\hline 10.1350 & 400.06 & 39512.9821 & 0.0000 & 33.6950 & 0.0272 & 0.3443 & 0.001 & 0.16 \\
\hline 5.0553 & 400.04 & 39513.4951 & 0.0008 & 32.6561 & & & & 0.38 \\
\hline 1.0233 & 400.06 & 39512.7072 & 1.0937 & 31.8197 & 0.1076 & 0.3070 & 0.002 & 0.68 \\
\hline 0.1008 & 399.07 & 39512.7240 & 1.0627 & 31.7850 & 0.1672 & 0.3063 & 0.003 & 1.05 \\
\hline
\end{tabular}




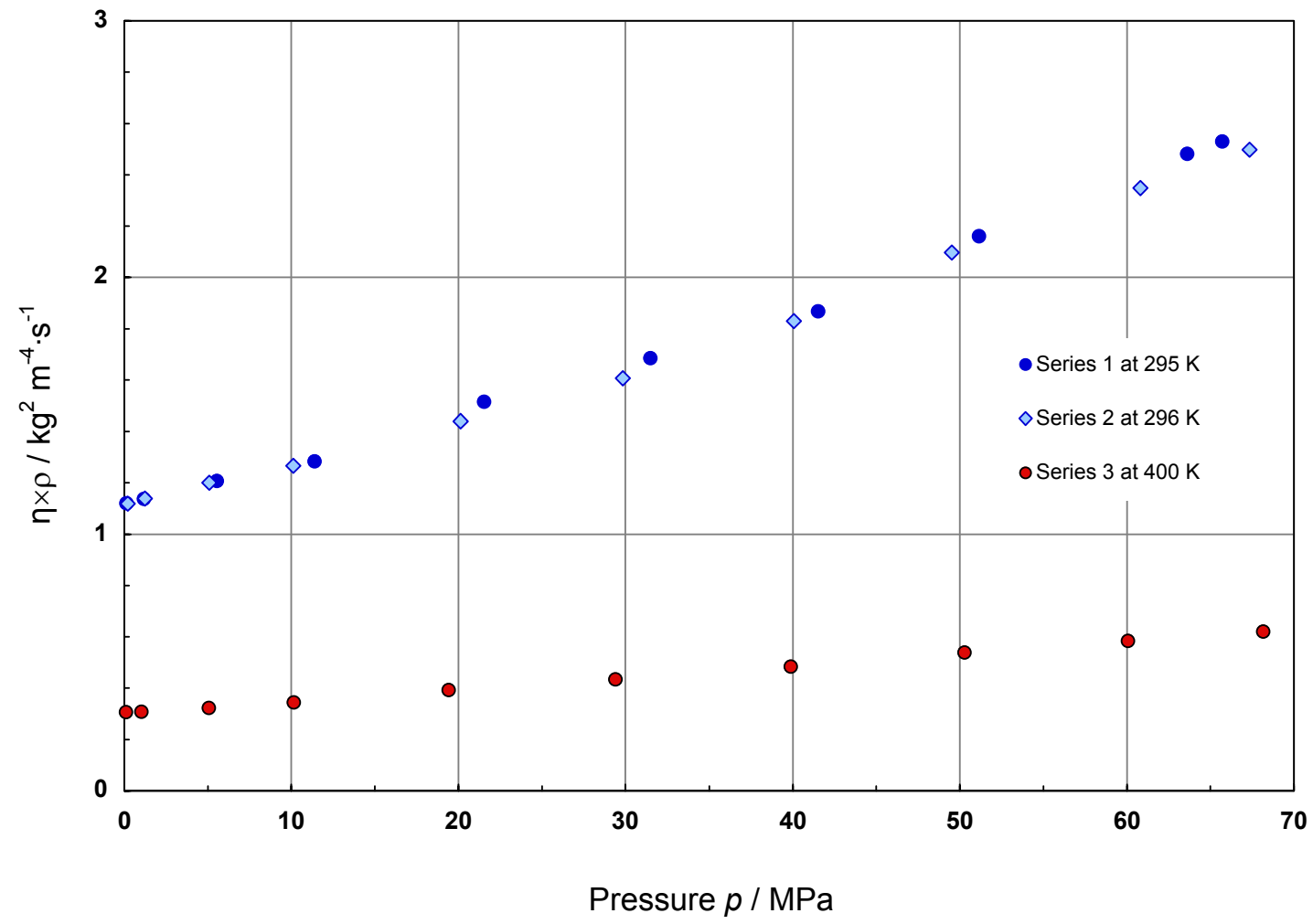

Figure 9. (Viscosity $\times$ density) product of RP-1 at elevated pressures measured in the torsional crystal viscometer at room temperature and at $400 \mathrm{~K}$. 


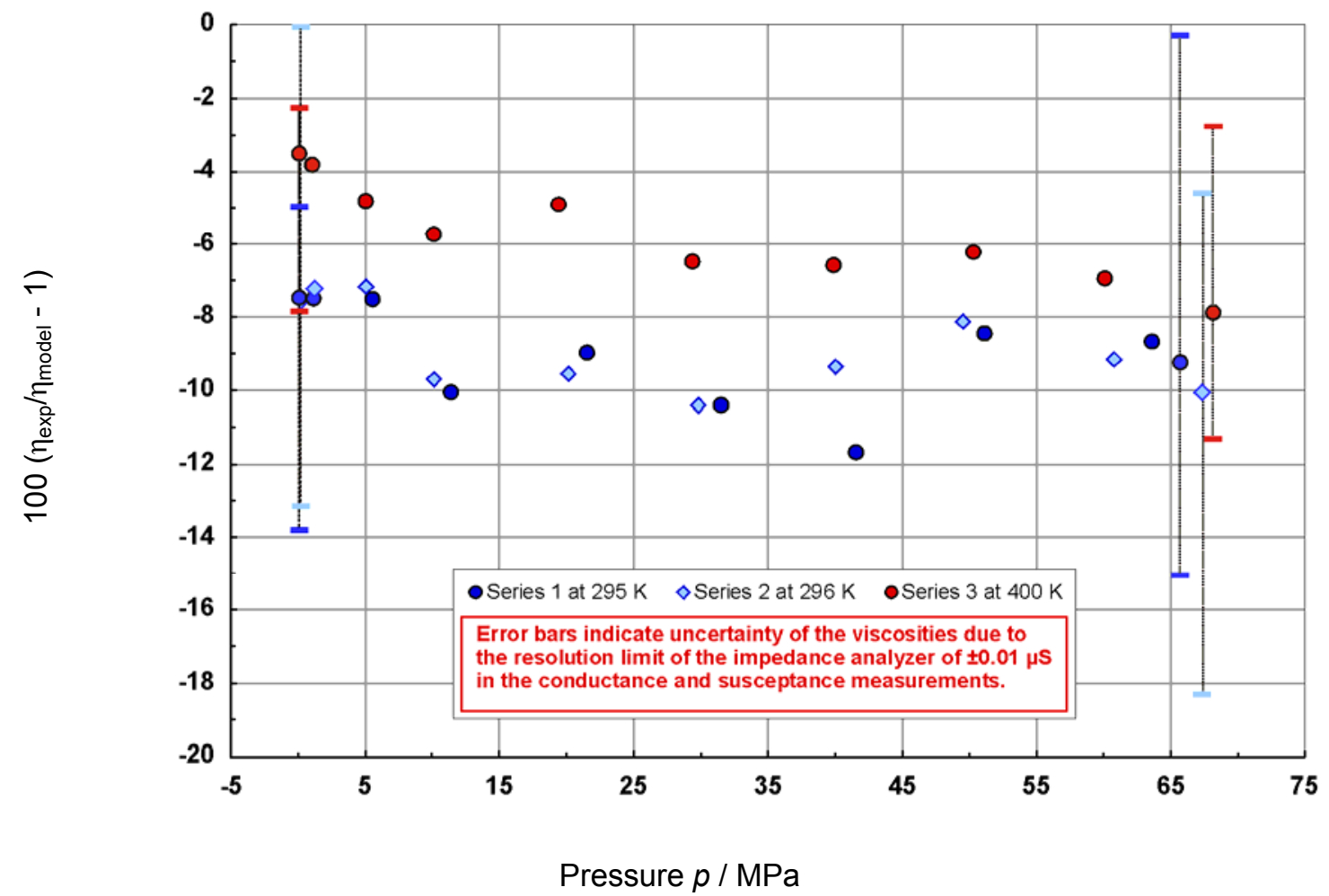

Figure 10. Percent deviations of the measured viscosities of RP-1 at elevated pressures from the model for the surrogate mixture. 


\section{Project Workshop at NIST Boulder on December 11, 2003}

On December 11, 2003, the Physical and Chemical Properties Division of CSTL hosted a project workshop at the Boulder campus of NIST on the thermophysical properties of the rocket propellant designated RP-1. Specialists in rocket fuels (from NASA, the U.S. Air Force, commercial rocket engine manufacturers, and academia) convened with NIST researchers to hear about recent NIST work conducted to help better define the properties of this fuel and to plan future activities required to achieve consensus standards for the properties of fuels over the broad ranges of conditions encountered in their use.

NIST researchers reported new, high sensitivity compositional characterizations of RP-1 fuels and new metrological quality property results for density, viscosity, heat capacity, and thermal conductivity with temperatures extending beyond a decomposition limit (near $600 \mathrm{~K}$ ) and pressures to about $70 \mathrm{MPa}$. These data were used to establish accurate preliminary property surfaces for this complex fluid. A software implementation of the preliminary models was delivered to NASA engineers and their contractors for testing and to assist in the resolution of current engine design problems. Participants in the workshop, listed in Table 13, were eager to use

the current results, and were very interested in continued NIST efforts to explore the effects of sample-to-sample variation and refined processing methods on fuel properties, to help establish new protocols for fuel characterization, and to expand the range of conditions and properties. 
Table 13. Participants in NIST Rocket Propellant Workshop.

NASA

Dr. Kendall Brown

NASA/MSFC/TD51

Liquid Engine Systems

Mail Code TD51

Marshall Space Flight Center, AL 35812

Email: kendall.k.brown@nasa.gov

Phone: (256) 544-5938

Fax: (256) 544-5876

Mr. Larry de Quay

NASA/SSC/VA305

Propulsion Test Division, Systems Analysis

Branch

Mail Code VA305

Stennis Space Center, MS

Email: larry.dequay-1@,nasa.gov

Phone: (228) 688-1956

Fax: (228) 688-1485

Mr. Darrell Gaddy

NASA/MSFC/ED25

Thermal Analysis

Mail Code ED25

Marshall Space Flight Center, AL 35812

Email: Darrell.E.Gaddy@nasa.gov

Phone: (256) 544-0198

Fax:

Mr. Van Loung

NASA/MSFC/ED25

Thermal Analysis

Mail Code ED25

Marshall Space Flight Center, AL 35812

Email: Van.Luong-1@nasa.gov

Phone: (256) 544-3070

Fax:
Mr. Mike Martin

NASA/MSFC/TD53

Performance Modeling

Mail Code TD53

Marshall Space Flight Center, AL 35812

Email: michael.a.martin@nasa.gov

Phone: (256) 544-4478

Fax:

Mr. Mike Meyer

NASA/GRC

21000 Brookpark Road

Cleveland, $\mathrm{OH} 44135$

Email: michael.1.meyer@nasa.gov

Phone: (216) 977-7492

Fax:

Mr. Joe Sims

NASA/MSFC/TD61

Combustion Devices

Mail Code TD61

Marshall Space Flight Center, AL 35812

Email: Joseph.D.Sims@,nasa.gov

Phone: (256) 544-4650

Fax:

Dr. Jeff West

NASA/MSFC/TD64

CFD

Mail Code TD64

Marshall Space Flight Center, AL 35812

Email:

Phone: (256) 544-6309

Fax:

\section{Industry Partners}

Mr. Tom Crofoot

Northrop Grumman Space Technology

Chemistry Technology Department

One Space Park/BldO1 Rm2020/

Redondo Beach, CA 90278

Email: tom.crofoot@ngc.com

Phone: (310) 813-4623

Fax:
Mr. Dave Ewing

Rocketdyne

Performance Modeling

6633 Canoga Park Ave.; P.O. Box 7922

Canoga Park, CA 91309-7922

Email:

Phone: (818) 586-0350

Fax: 
Dr. He Huang

United Technologies Research Center

Thermal Mgt

MS 129-29, 411 Silver Lane,

East Hartford, CT 06108

Email: HuangH@utrc.utc.com

Phone: (860) 610-7594

Fax: $\quad$ (880) 660-1178

Mr. Mike Krene

Rocketdyne

TCA IPT Lead

6633 Canoga Park Ave.; P.O. Box 7922

Canoga Park, CA 91309-7922

Email:

Phone: (818) 360-2321

Fax:

Mr. Herb Lander

Rocketdyne

Hydrocarbon Fuel Analyst

1964 W. Wide River Dr.

St. George, UT 84790

Email: JP10fuel@aol.com

Phone: (435) 673-4323

Fax:

Mr. Buzz Laning

Lockheed Martin Corporation

Vehicle MPS

DC3006; P.O. Box 179

Denver, Colorado 80201

Email: buzz.lanning@lmco.com

Phone: 303) 971-9390

Fax:
Mr. Dennis Lim

Rocketdyne

TCA Design

6633 Canoga Park Ave.; P.O. Box 7922

Canoga Park, CA 91309-7922

Email:

Phone: (818) 586-0422

Fax:

Mr. Skip Urquhart

Pratt \& Whitney

RBCC

P.O. Box 109600, M/S 712-67

West Palm Beach, Fl. 33410-9600

Email: james.urquhart@pw.utc.com

Phone: (561) 796-9706

Fax:

Mr. Brian Wherley

Rocketdyne

TCA IPT Sub-lead

6633 Canoga Park Ave., P.O. Box 7922

Canoga Park, CA 91309-7922

Email:

Phone: (818) 586-1785

Fax:

Mr. Peter Zeender

Chemical Propulsion Information Agency

Properties Documentation

10630 Little Patuxent Parkway, Suite 202

Columbia, MD 21044

Email: pzeender@cpia.jhu.edu

Phone: (410) 992-9950 x205

Fax:

\section{University Partners}

Dr. Brian Landrum

University of Alabama Huntsville

Professor

Technology Hall, S-227, Univ of Alabama in

Huntsville

Huntsville, Al 35899

Email: landrum@mae.uah.edu

Phone: (256) 824-7207

Fax:
Mr. Ben Stiegemeier

University of Toledo 21000 Brookpark Road

Cleveland, $\mathrm{OH} 44135$

Email: ben.steigemeier@grc.nasa.gov

Phone: (216) 433-8242

Fax: 


\section{Military Partners}

Dr. Tim Edwards

Air Force Research Laboratory

Propulsion Directorate

Wright-Patterson AFB, OH

Email: james.edwards@wpafb.af.mil

Phone: (937) 255-3524

Fax:

\section{NIST Staff}

Dr. Thomas Bruno

NIST Physical \& Chemical Properties Division 325 Broadway, MC 838.00

Boulder, CO 80305-3328

Email: bruno@boulder.nist.gov

Phone: (303) 497-5158

Fax: (303) 497-5224

Dr. Rob Chirico

NIST Physical \& Chemical Properties Division 325 Broadway, MC 838.00

Boulder, CO 80305-3328

Email: chirico@boulder.nist.gov

Phone: (303) 497-4126

Fax: (303) 497-5224

Dr. Michael Frenkel NIST Physical \& Chemical Properties Division 325 Broadway, MC 838

Boulder, CO 80305-3328

Email: frenkel@,boulder.nist.gov

Phone: (303) 497-3952

Fax: (303) 497-5224

Dr. Daniel Friend

NIST Physical \& Chemical Properties Division 325 Broadway, MC 838

Boulder, CO 80305-3328

Email: dfriend@,boulder.nist.gov

Phone: (303) 497-5424

Fax: (303) 497-5044

Dr. Marcia Huber

NIST Physical \& Chemical Properties Division 325 Broadway, MC 838.08

Boulder, CO 80305-3328

Email: huber@boulder.nist.gov

Phone: (303) 497-5252

Fax: (303) 497-5224
Dr. Arno Laesecke

NIST Physical \& Chemical Properties Division 325 Broadway, MC 838.07

Boulder, CO 80305-3328

Email: laesecke@,boulder.nist.gov

Phone: (303) 497-3197

Fax: (303) 497-5224

Dr. Eric Lemmon

NIST Physical \& Chemical Properties Division 325 Broadway, MC 838.08

Boulder, CO 80305-3328

Email: ericl@boulder.nist.gov

Phone: (303) 497-7939

Fax: (303) 497-5224

Dr. Joseph Magee

NIST Physical \& Chemical Properties Division 325 Broadway, MC 838.07

Boulder, CO 80305-3328

Email: magee@boulder.nist.gov

Phone: (303) 497-3298

Fax: (303) 497-3441

Dr. Jeffrey Manion

NIST Physical \& Chemical Properties Division 100 Bureau Drive, Stop 8381

Gaithersburg, MD 20899-8381

Email: jeffrey.manion@,nist.gov

Phone: (301) 975-3188

Fax:

Dr. Mark McLinden

NIST Physical \& Chemical Properties Division 325 Broadway, MC 838.07

Boulder, CO 80305-3328

Email: mclinden@boulder.nist.gov

Phone: (303) 497-3580

Fax: (303) 497-5224 
Dr. Richard Perkins

NIST Physical \& Chemical Properties Division

325 Broadway, MC 838.07

Boulder, CO 80305-3328

Email: perkins@boulder.nist.gov

Phone: (303) 497-5499

Fax: (303) 497-5224
Dr. Jason Widegren

NIST Physical \& Chemical Properties Division 325 Broadway, MC 838.07

Boulder, CO 80305-3328

Email: widegren@boulder.nist.gov

Phone: (303) 497-5207

Fax: (303) 497-5224

\section{NIST Guests}

Mr. Aziz Abdulagatov

NIST Physical \& Chemical Properties Division

325 Broadway, MC 838.07

Boulder, CO 80305-3328

Email: aziz@boulder.nist.gov

Phone: (303) 497-3716

Fax: (303) 497-5224

Dr. Ilmutdin Abdulagatov

NIST Physical \& Chemical Properties Division 325 Broadway, MC 838.07

Boulder, CO 80305-3328

Email: Ilmutdin@,boulder.nist.gov

Phone: (303) 497-4027

Fax: (303) 497-5224

Dr. Peter Andersen

NIST Physical \& Chemical Properties Division 325 Broadway, MC 838

Boulder, CO 80305-3328

Email: panderse@,boulder.nist.gov

Phone: (303) 497-5614

Fax: (303) 497-5224
Dr. Jörg Baranski

NIST Physical \& Chemical Properties Division 325 Broadway, MC 838.07

Boulder, CO 80305-3328

Email: baranski@boulder.nist.gov

Phone: (303) 497-3522

Fax: (303) 497-5224

Dr. Jesus Sanchez Ochoa

NIST Physical \& Chemical Properties Division 325 Broadway, MC 838.07

Boulder, CO 80305-3328

Email: jsanchez@,boulder.nist.gov

Phone: (303) 497-4167

Fax: (303) 497-5224

Mr. Hong-Wei Xiang

NIST Physical \& Chemical Properties Division 325 Broadway, MC 838

Boulder, CO 80305-3328

Email: hwxiang@boulder.nist.gov

Phone: (303) 497-7752

Fax: (303) 497-5224 


\section{Summary and Recommendations}

A combined experimental and modeling study was carried out to elucidate the behavior of key properties over wide ranges of temperature and pressure. An RP-1 sample provided by the Air Force Research Lab (Wright-Patterson AFB, OH) was chemically characterized. Thermophysical properties were then measured for this sample. The experimental results were used to develop a mixture model based on a representative surrogate mixture. The results of this study were presented for review and comments in the December 11, 2003 workshop attended by representatives of NASA, the U.S. Air Force and their contractors.

The anticipated impact of the knowledge of thermophysical properties developed in this study will be more efficient and cost-effective rocket engine systems that use the kerosene rocket propellant designated RP-1. For future work, it is recommend that the variation of RP-1 properties be systematically explored based on studies of RP-1 samples from different lots. This will help design engineers to better understand the effects of batch-to-batch variability on the thermophysical properties of RP-1, and thus to lead to a more flexible engine design that performs equally well with RP-1 from various distillation batches or vendors. In the longer term, it is recommended that the mixture property model developed here, and the approach used to obtain the model from accurate experimental measurements, be applied to other kerosene-type fuels that are widely used in jet aviation. This information is expected to enhance the design and performance characterization of jet engines, especially those that will see applications in supersonic flight where fuels encounter both high temperatures and pressures.

Financial support for this project was provided by the NASA John H. Glenn Research Center. 


\section{References}

[1] Lemmon, E. W.; McLinden, M. O.; Huber, M. L. REFPROP, reference fluid thermodynamic and transport properties. NIST Standard Reference Database 23; Version 7 ed. (2002).

[2] Lemmon, E. W.; Jacobsen, R. T. A generalized thermodynamic model for the thermodynamic properties of mixtures. Int. J. Thermophys. 20: 825-835 (1999).

[3] Huber, M. L.; Ely, J. F. Prediction of the viscosity of refrigerants and refrigerant mixtures. Fluid Phase Equilib. 80: 239-248 (1992).

[4] Huber, M. L.; Ely, J. F. Prediction of the thermal conductivity of refrigerants and refrigerant mixtures. Fluid Phase Equilib. 1992; 80: 249-261.

[5] Lemmon, E. W.; Huber, M. L. Thermodynamic properties of n-dodecane. Energy and Fuels 18: 960-967 (2004).

[6] Huber, M. L.; Laesecke, A.; Perkins, R. A. Transport properties of n-dodecane. Energy and Fuels 18: 968-975 (2004).

[7] Andresen, J. M.; Strohm, J. J.; Sun, L. Relationship between the formation of aromatic compounds and solid deposition during thermal degradation of jet fuels in the pyrolytic regime. Energy Fuels 15: 714-723 (2001).

[8] Balster, W. J.; Jones, E. G. Effects of temperature on formation of insolubles in aviation fuels. J. Eng. Gas. Turbines Power, Trans. ASME 120: 289-293 (1998).

[9] Batti, F. Thermal stability of jet fuels. Lembaran Publikasi Lemigas 24: 18-22 (1990).

[10] Behar, F.; Lorant, F.; Budzinski, H.; Desavis, E. Thermal stability of alkylaromatics in natural systems: kinetics of thermal decomposition of dodecylbenzene. Energy Fuels 16: 831-841 (2002).

[11] Chin, J. S.; Lefebvre, A. H.; Sun, F. T. Y. Temperature effects on fuel thermal-stability. j. eng. gas. turbines power, Trans. ASME 114: 353-358 (1992).

[12] Chin, J. S.; Lefebvre, A. H. Experimental techniques for the assessment of fuel thermal stability. J. Propul. Power 8: 1152-1156 (1992).

[13] Chin, J. S.; Lefebvre, A. H. Experimental study on hydrocarbon fuel thermal stability. J. Thermal Sci. 1: 70-74 (1992).

[14] Chin, J. S.; Lefebvre, A. H. Influence of flow conditions on deposits from heated hydrocarbon fuels. J. Eng. Gas. Turbines Power, Trans. ASME 115: 433-438 (1993).

[15] Edwards, T.; Zabarnick, S. Supercritical fuel deposition mechanisms. Indust. Eng. Chem. Res. 32: 3117-3122 (1993).

[16] Giovanetti, A. J.; Spadaccini, L. J.; Szetela, E. J. Deposit formation and heat-transfer characteristics of hydrocarbon rocket fuels. J. Spacecraft Rockets 22: 574-580, (1985).

[17] Goel, P.; Boehman, A. L. Numerical simulation of jet fuel degradation in flow reactors. Energy Fuels 14: 953-962 (2000).

[18] Grinstead, B.; Zabarnick, S. Studies of jet fuel thermal stability, oxidation, and additives using an isothermal oxidation apparatus equipped with an oxygen sensor. Energy Fuels 13: 756-760 (1999).

[19] Han-Ying, M. A Study on Thermal Stability and its improvement of hydrocarbon fuel. Energetic Materials--Insensitivity and Environment Awareness International Annual Conf.; Karlsruhe, Germany, 88.81 -88.12 (1993).

[20] Heneghan, S. P.; Martel, C. R.; Williams, T. F.; Ballal, D. R. Studies of jet fuel thermal stability in a flowing system. J. Eng. Gas Turbines Power 115: 480-485 (1993). 
[21] Heneghan, S. P.; Harrison, W. E.; III. JP-8+100: the development of high thermal stability jet fuel. Proc.; $6^{\text {th }}$ Intl. Conf. on Stability and Handling of Liquid Fuels, Oct. 13-17, 1997 , Vancouver, B.C. 1: 271-283 (1998).

[22] Hines, W. S. Heat transfer to RP-1 kerosine in turbulent flow under asymmetric heating conditions. Chemical Engineering Progress, Symp. Series 59: 193-200 (1963).

[23] Kendall, D. R.; Mills, J. S. Thermal stability of aviation kerosines: Techniques to characterize their oxidation properties. Indust. Eng. Chem. Product Res. Devel. 25: 360-367 (1986).

[24] Lai, W. C.; Song, C. S. Pyrolysis of alkylcyclohexanes in or near the supercritical phase. Product distribution and reaction pathways. Fuel Process. Technol.; 48: 1-27 (1996).

[25] Liang, K.; Yang, B.; Zhang, Z. Investigation of heat transfer and coking characteristics of hydrocarbons fuels. J. Propul. Power 14: 789-796 (1998).

[26] Ma, H. A study on thermal stability and its improvement of hydrocarbon fuel. 24th Intl. Ann. Conf. of ICT 88/81-12 (1993).

[27] Marteney, P. J.; Spadaccini, L. J. Thermal decomposition of aircraft fuel. J. Eng. Gas Turbines Power 108: 648-653 (1986).

[28] Pande, S. G.; Hardy, D. R. Comparison of the effects of storage conditions, type of soluble copper, and MDA on JP-5 fuel thermal stability. Proc.; 6th Intl. Conf. on Stability and Handling of Liquid Fuels, Oct. 13-17, 1997, Vancouver, B.C. 1: 211-230 (1998).

[29] Roback, R.; Szetela, E. J.; Spadaccini, L. J. Deposit formation in hydrocarbon fuels. J. Eng. Power 105: 59-65 (1983).

[30] Savage, P. E.; Gopalan, S.; Mizan, T. I.; Martino, C. J.; Brock, E. E. Reactions at supercritical conditions: Applications and fundamentals. AIChE J. 41: 1723-1778 (1995).

[31] Stekhun, A. I. Effect of hydrofining on thermal stability of jet fuels. Ekspluat. Svoistva Aviats. Topliv 3:180-186 (1972).

[32] Stewart, J.; Brezinsky, K.; Glassman, I. Supercritical pyrolysis of decalin, tetralin, and n-decane at 700-800 K. Product distribution and reaction mechanism. Combust. Sci. Technol. 136: 373-390 (1998).

[33] Stiegemeier, B. A thermal stability and heat transfer investigation of five hydrocarbon fuels; 38th AIAA/ASME/SAE/ASEE Joint Propulsion Conf. and Exhibit, Indianapolis, IN, AIAA Paper 3873 (2002).

[34] Wang, T.-S. Thermophysics characterization of kerosene combustion. J. Thermophys. Ht. Trans. 15: 140-147 (2001).

[35] Watkinson, A. P.; Wilson, D. I. Chemical reaction fouling: A review. Exp. Thermal Fluid Sci. 14: 361-374 (1997).

[36] Wohlwend, K.; Maurice, L. Q.; Edwards, T. Thermal stability of energetic hydrocarbon fuels for use in combined cycle engines. J. Propul. Power 17: 1258-1262 (2001).

[37] Yu, J.; Eser, S. Determination of critical properties (T-C, P-C) of some jet fuels. Indust. Eng. Chem. Res. 34: 404-409 (1995).

[38] Yu, J.; Eser, S. Thermal decomposition of c10-c14 normal akanes in near-critical and supercritical conditions: Product distributions and reaction mechanisms. Ind. Eng. Chem. 36: 574-584 (1997).

[39] Yu, J.; Eser, S. Kinetics of supercritical-phase thermal decomposition of C10-C14 normal alkanes and their mixtures. Ind. Eng. Chem. 36: 585-591 (1997).

[40] Yu, J. A.; Eser, S. Thermal decomposition of jet fuel model compounds under near-critical and supercritical conditions. 1. n-butylbenzene and n-butylcyclohexane. Indust. Eng. 
Chem. Res. 37: 4591-4600 (1998).

[41] Yu, J.; Eser, S. Thermal decomposition of jet fuel model compounds under near-critical and supercritical conditions. 2. Decalin and tetralin. Ind. Eng. Chem. 37: 4601-4608 (1998).

[42] Yu, J.; Eser, S. Supercritical-phase thermal decomposition of binary mixtures of jet fuel model compounds. Fuel 79: 759-768 (2000).

[43] Volokhova, G. S.; Zhorov, Y. M. Composiiton of aromatic hydrocarbons in kerosine-gasoil cuts (in Russian). Khim. Tekhnol. Topl. Masel 12: 33-35 (1980).

[44] Edwards, T.; Maurice, L. Q. Surrogate mixtures to represent complex aviation and rocket fuels. J. Propul. Power 17: 461-466 (2001).

[45] Edwards, T. "Kerosene" fuels for aerospace propulsion: Composition and properties. Proc. 38th AIAA/ASME/SAE/ASEE Joint Propulsion Conf.; July 7-10, 2002, Paper No. 2002-3874 (2002)

[46] Farmer, R. C.; Anderson, P. G.; Cheng, G. C.; Myruski, B. L.; Pike, R. W. Propulsion chemistry for CFD applications, SECA, Inc.; Huntsville, AL (1997).

[47] Patterson, P. M.; Kyne, A. G.; Pourkashanian, M.; Williams, A. Combustion of kerosene in counterflow diffusion flames. J. Propul. Power 16: 453-460 (2000).

[48] Violi, A.; Yan, S.; Eddings, E. G.; Sarofim, A. F.; Granata, S.; Faravelli, T.; Ranzi, E. Experimental formulation and kinetic model for JP-8 surrogate mixtures. Combust. Sci. Technol. 174: 399-417 (2002).

[49] Wang, T.-S. Thermo-kinetics characterization of kerosine/RP-1 combustion; 32nd AIAA/ASME/SAE/ASEE Joint Propulsion Conf.; Lake Buena Vista, FL, 10 (1996).

[50] Wood, C. P.; McDonell, V. G.; Smith, R. A.; Samuelson, G. S. Development and application of a surrogate distillate fuel. J. Propul. Power 5: 399-405 (1989).

[51] Alexander D. R.; Kalwala, R.; Kubik, R. D.; Schaub, S. A. Complex index-of-refraction measurements for RP-1 liquid rocket fuel. Opt. Eng. 34: 913-921 (1995).

[52] Blake, F. C.; Sheard, C. On the dielectric constant of kerosene and water for high frequency currents. Phys. Rev. 15: 148-149 (1920).

[53] Chao, G. T. Y. Isothermal compressibility of liquid oxygen and RP-1. ARS J. 29: 199-203 (1959).

[54] CPIA/M4 Liquid propellant manual, Unit 20a. Chemical Propulsion Information Agency, Johns Hopkins University, Columbia, MD (2002).

[55] Dubovkin, N. F.; Tararyshkin, M. E.; Abashina, L. D. Vapor pressure and critical parameters of jet fuels (in Russian). Khim. Tekhnol. Topl. Masel 4: 34-37 (1981).

[56] Kopylov, N. I. Trudy Moskovskogo Aviatsionnogo Instituta (Trans. Moscow Aviation Inst.) 132: 45-56 (1961).

[57] Kozyukov, A. V. Trudy Moskovskogo Aviatsionnogo Instituta (Trans. Moscow Aviation Inst.) 132: 94-108 (1961).

[58] Mehta, G.; Stone, W.; Ingram, C.; Bai, S.; Sanders, T. Comparative testing of Russian kerosene and RP-1. 31st AIAA/ASME/SAE/ASEE Joint Propulsion Conf. and Exhibit, San Diego, CA, AIAA 95-2962, 11 (1995).

[59] Piatibratov, S. N. Trudy Moskovskogo Aviatsionnogo Instituta (Trans. Moscow Aviation Inst.) 132: 31-44 (1961).

[60] Sharma, R. L.; Tewari, G. B.; Singh, J. A new equation for predicting flash point of kerosine. Indian J. Technol. 31: 882-884 (1993).

[61] Sokolov, S. N.; Tarlakov, Y. V. Trudy Moskovskogo Aviatsionnogo Instituta (Trans. 
Moscow Aviation Inst.) 132: 15-30 (1961).

[62] Sokolov, S. N.; Tarlakov, Y. V. Trudy Moskovskogo Aviatsionnogo Instituta (Trans. Moscow Aviation Inst.) 132: 116-122 (1961).

[63] Stiegemeier, B. A Thermal stability and heat transfer investigation of five hydrocarbon fuels: JP-7, JP-8, JP-8+100, JP-10 and RP-1. B.S.; University of Kansas, Lawrence, KS (1998).

[64] Vinogradov, A. N. Physicochemical properties and composition of a magnetic kerosene-based fluid. Russ. J. Phys. Chem. 74: 1192-1195 (2000).

[65] Volyak, L. D. Trudy Moskovskogo Aviatsionnogo Instituta (Trans. Moscow Aviation Inst.) 132: 63-76 (1961).

[66] Wucherer, E. J.; Wilson, A. Chemical, physical and hazards properties of quadricyclane. AFRL/PRS, Edwards AFB, CA (1998).

[67] Zaytseva, L. S. Trudy Moskovskogo Aviatsionnogo Instituta (Trans. Moscow Aviation Inst.) 132: 79-93 (1961).

[68] Technical data book: Petroleum refining, 4th ed. American Petroleum Inst.; Vol. II (1983).

[69] Baroncini, C.; Di Filippo, P.; Latini, G.; Pacetti, M. Organic liquid thermal conductivity: A prediction method in the reduced temperature range 0.3 to 0.8 . Int. J. Thermophys. 2: 21-38 (1981).

[70] Chung, T. H.; Ajlan, L.; Lee, L. L.; Starling, K. E. Generalized multiparameter correlation for nonpolar and polar fluid transport properties. Ind. Eng. Chem. Res. 27: 671-679 (1988).

[71] Constantinou, L.; Gani, R. New group-contribution method for estimating properties of pure compounds. AIChE J. 40: 1697-1710 (1994).

[72] Deppmeier, B. J.; Driessen, A. J.; Hehre, W. J.; Klunzinger, P. E.; Le, T.; Yu, J. PC Spartan Plus 2.0.0, March 2000 ed.; Wavefunction, Inc.: Irvine, CA (2000).

[73] Ely, J. F.; Hanley, H. J. M. Prediction of transport properties. 1. Viscosity of fluids and mixtures. Ind. Eng. Chem. Fundamentals 20: 323-332 (1981).

[74] Ely, J. F.; Hanley, H. J. M. Prediction of transport properties. 2. Thermal conductivity of pure fluids and mixtures. Ind. Eng. Chem. Fundamentals 22: 90-97 (1983).

[75] Horvath, A. L. Molecular design: Chemical structure generation from the properties of pure organic compounds. Elsevier: New York, NY (1992).

[76] Joback, K. J. A unified approach to physical property estimation using multivariate statistical techniques. S.M.; Mass. Inst. Technol.; Cambridge, MA (1984).

[77] Marrero, J.; Gani, R. Group-contribution based estimation of pure component properties. Fluid Phase Equilib. 183: 183-208 (2001).

[78] Poling, B. E.; Prausnitz, J. M.; O'Connell, J. P. The properties of gases and liquids, 5th ed.; McGraw-Hill: New York, NY (2001).

[79] Quayle, O. R. The parachors of organic compounds. An interpretation and catalogue. Chem. Rev. 53: 439-589 (1953).

[80] Rihani, D. N.; Doraiswamy, L. K. Estimation of the heat capacity of organic compounds from group contributions. Ind. Eng. Chem. 4: 17-21 (1965).

[81] Stein, S. E.; Brown, R. L. Structures and Properties Group additivity model. NIST Chemistry WebBook, NIST Standard Reference Database Number 69 (http://webbook.nist.gov). March 2003 ed. (2003).

[82] Wilson, G. M.; Jasperson, L. V. Critical Tc, Pc estimation based on zero, first, second-order methods; AIChE Meeting New Orleans, LA (1996).

[83] Yan, X.; Dong, Q.; Hong, X. Reliability analysis of group-contribution methods in 
predicting critical temperatures of organic compounds. J. Chem. Eng. Data 48: 374-380 (2003).

[84] Coops, J.; van Kamp, H.; Lambregts, W. A.; Visser, B. J.; Dekker, H. Thermal properties of cycloparaffins, IV. Heats of combustion of cycloparaffins with 10-17C at. Recl. Trav. Chim. Pays-Bas 79: 1226 (1960).

[85] Drotloff, H.; Moller, M. On the phase transitions of cycloalkanes. Thermochim. Acta 112: 57-62 (1987).

[86] Fischer, J.; Weiss, A. Transport properties of liquids. V. Self diffusion, viscosity, and mass density of ellipsoidal shaped molecules in the pure liquid phase. Ber. Bunsenges. Phys. Chem. 90: 896-905 (1986).

[87] Gollis, M. H.; Belenyessy, L. I.; Gudzinowicz, B. J.; Koch, S. D.; Smith, J. O.; Wineman, R. J. Evaluation of pure hydrocarbons as jet fuels. J. Chem. Eng. Data 7: 311-316 (1962).

[88] Ladygin, B. Y.; Zinina, G. M.; Vannikov, A. V. Izvestiya Akademii Nauk SSSR, Seriya Khimicheskaya 1018 (1984).

[89] Matteoli, E.; Lepori, L.; Spanedda, A. Volumetric properties of cyclic hydrocarbons in tetrachloromethane at 25C. J. Solution Chem. 23: 619-638 (1994).

[90] Meyer, E. F.; Hotz, C. A. Cohesive energies in polar organic liquids. 3. Cyclic ketones. J. Chem. Eng. Data 21: 274-279 (1976).

[91] Mueller, E.; Padeken, H. G.; Salamon, M.; Fiedler, G. Direct photooxidation of cycloalkanes. Chem. Ber. 98: 1893-1909 (1965).

[92] Ruzicka, L.; Stoll, M.; Huyser, H.; Boekenoogen, H. A. Zur Kenntnis des Kohlenstoffringes XV uber die Herstellung und einige physikalische Daten verschiedener Kohlenstoffringe bis zum 32-Ring. Helv. Chim. Acta 13: 1152-1185 (1930).

[93] Allinger, N. L. The relative stabilities of cis and trans isomers: III. The cyclodecenes. J. Am. Chem. Soc. 79: 3443-3446 (1957).

[94] Blomquist, A. T.; Burge, R. E.; Sucsy, A. C. Many-Membered Carbon Rings V. Cyclodecyne, cis- and trans-cyclodecene, and related compounds. J. Am. Chem. Soc. 74: 3636-3642 (1952).

[95] Cope, A. C.; Mclean, D. C.; Nelson, N. A. Cyclic Polyolefins XXXVI. Trans-cyclononene and trans-cyclodecene from cyclononyldimethylamine oxide and cyclodecyldimethylamine oxide. J. Am. Chem. Soc. 77: 1628-1631 (1955).

[96] Prelog, V.; Schenker, K.; Guenthard, H. H. Carbon rings, LX. The ten-membered ring. Helv. Chim. Acta 35: 1598-1615 (1952).

[97] Gibbons, L. C. PhD, Ohio State Univ, Columbus, OH (1941).

[98] Levene, P. A.; Harris, S. A. Configurational relationships of methylphenyl- and methylhexylacetic acids and an attempt at the correlation of the configurations of 2-hydroxy acids with those of disubstituted acetic acids containing a methyl group. J. Biol. Chem. 112: 195-208 (1935).

[99] Mann, G.; Muehlstaedt, M.; Braband, J. Conformation and physical data of alkanes and cyclanes. II. Single- and double-branched alkanes. Tetrahedron 23: 3393-3401 (1967).

[100] Marsh, K. N.; Wilhoit, R. C.; Frenkel, M.; Yin, D. TRC Thermodynamic properties of substances in the ideal gas state; 1.0M ed.; Thermodynamics Research Center (TRC) (1994).

[101] Petrov, A. A.; Sergienko, S. R.; Nechitailo, N. A.; Tsedilina, A. L. Izvestiya Akademii Nauk SSSR, Seriya Khimicheskaya 1091-1097 (1959).

[102] Prout, F. S.; Cason, J.; Ingersoll, A. W. Branched-Chain Fatty Acids V. The synthesis of 
optically active 10-methyloctadecanoic acids. J. Am. Chem. Soc. 70: 298 (1948).

[103] Smith, D. C. Infrared spectra of pure hydrocarbons, Nav. Res. Lab. Rep. (U.S.) C-3274 (1948).

[104] Terres, E.; Gebert, F.; Fischer, D.; Modak, G. Brennst.-Chem. 35: 263-269 (1954).

[105] Calingaert, G.; Soroos, H. The methyl nonanes. J. Am. Chem. Soc. 58: 635-636 (1936).

[106] Calingaert, G.; Soroos, H. A method of comparison and critical analysis of the physical properties of homologs and isomers. The Molecular Volume of Alkanes. J. Am. Chem. Soc. 58: 153-157 (1936).

[107] Dyke, W. J. C.; Jones, W. J. J. Chem. Soc. (London) 2426 (1930).

[108] Eykman, J. F. Natuurkd. Verh. Hollandsche Maatschappij Wet. Haarlem 8: 438-555 (1919).

[109] Geist, J. M.; Cannon, M. R. Viscosities of pure hydrocarbons. Ind. Eng. Chem. An. Ed. 18: 611-613 (1946).

[110] Mears, T. W.; Fookson, A.; Pomerantz, P.; Rich, E. H.; Dussinger, C. S.; Howard, F. L. Syntheses and properties of two olefins, six paraffins, and their intermediates. Nat. Bur. Stand (U.S.) J. Res. 44: 299 (1950).

[111] Moore, G. E.; Renquist, M. L.; Parks, G. S. Thermal data on organic compounds. XX. Modern combustion data for two methylnonanes, methyl ethyl ketone, thiophene and six cycloparaffins. J. Am. Chem. Soc. 62: 1505-1507 (1940).

[112] Parks, G. S.; West, T. J.; Moore, G. E. Thermal data on organic compounds. XXI. Some heat capacity, entropy and free energy data form the four methylnonanes. J. Am. Chem. Soc. 63: 1133-1135 (1941).

[113] Calingaert, G.; Hladky, J. W. A method of comparison and critical analysiss of the physical properties of homologs and isomers. The molecular volume of alkanes. J. Am. Chem. Soc. 58: 153 (1936).

[114] Howard, F. L.; Mears, T. W.; Fookson, A.; Pomerantz, P.; Brooks, D. B. Preparation and physical properties of several aliphatic hydrocarbons and intermediates. Nat. Bur. Stand. (U.S.) J. Res. 38: 365 (1947).

[115] Ambrose, D. Critical temperatures of some phenols and other organic compounds. Trans. Farad. Soc. 59: 1988 (1963).

[116] Briggs, D. K. H. Thermal conductivity of liquids. Ind. Eng. Chem. 49: 418-421 (1957).

[117] Byers, C. H.; Williams, D.F. Viscosities of pure polyaromatic hydrocarbons. J. Chem. Eng. Data 32: 344-348 (1987).

[118] Camin, D. L.; Rossini, F. D. Physical properties of 14 American Petroleum Institute research hydrocarbons, C9 to C15. J. Phys. Chem. 59: 1173-1179 (1955).

[119] Coulson, E. A. Preparation of alpha- and beta-methylnaphthalene from tar-oil fractions: I beta-methylnaphthalene. J. Soc. Chem. Ind. (London) 60: 123 (1941).

[120] Cullinane, N. M.; Chard, S. J. Action of methanol on naphthalene in the presence of catalysts of the auliman-silica type. formation of 2-methylnaphthalene. J. Chem. Soc. (London) 804 (1948).

[121] Cumper, C. W. N.; Redford, D. G.; Vogel, A. I. Physical properties and chemical constitution. The eletric dipole moments of methylquinolines. J. Chem. Soc. (London) 1176 (1962).

[122] Evans, E. B. The viscosities of hydrocarbons. J. Inst. Petroleum Tech. 24: 321-337 (1938).

[123] Glaser, F.; Ruland, H. Vapor pressure curves and critical data for several technically important organic substances (in German). Chem.-Ing.-Tech. 29: 772-775 (1957). 
[124] Grodde, K. H. Phys. Z. 39: 772 (1938).

[125] Grosse, A. V.; Ipatieff, V. N. The reaction of cycloparaffins with aromatic hydrocarbons: decycloalkylation. J. Org. Chem. 2: 447-458 (1937).

[126] Hales, J. L.; Townsend, R. Liquid densities from 293 to $490 \mathrm{~K}$ of nine aromatic hydrocarbons. J. Chem. Thermodyn. 4: 763-772 (1972).

[127] Huffman, H. M.; Parks, G. S.; Barmore, M. Thermal data on organic compounds X. Further studies on the heat capacities, entropies, and free energies of hydrocarbons. J. Am. Chem. Soc. 53: 3876-3888 (1931).

[128] Koelbel, H. Alkylnaphthalenes as lubricating-oil models. Brennst.-Chem. 30: 73-80 (1949).

[129] Larsen, R. G.; Thorpe, R. E.; Armfield, F. A. Oxidation characteristics of pure hydrocarbons. Ind. Eng. Chem. 34: 183-193 (1942).

[130] Luther, H.; Wachter, G. Preparation and physical properties of alkyl substituted naphthalene. Chem. Ber. 82: 161-176 (1949).

[131] Mair, B. J.; Streiff, A. J. Separation of the aromatic hydrocarbons, and the isolation of n-dodecane, naphthalene, 1-methylnaphthalene, and 2-methylnaphthalene from the kerosene fraction of petroleum. Nat. Bur. Stand. (U.S.) J. Res. 24: 395-414 (1940).

[132] Neuhaus, A. Z. Kristallogr. 101: 177 (1939).

[133] Parks, G. S.; Huffman, H. M. Some fusion and transition data for hydrocarbons. Ind. Eng. Chem. 23: 1138-1139 (1931).

[134] Rampolla, R. W.; Smyth, C. P. Microwave absorption and molecular structure in liquids. XXI. Relaxation times, viscosities and molecular shapes of substituted pyridines, quinolines and naphthalenes. J. Am. Chem. Soc. 80: 1057-1061 (1958).

[135] Salceanu, C. C. R. Hebd. Seances Acad. Sci. 193: 161 (1931).

[136] Schiessler, R. W. American Doc. Inst. Doc. No. 4597 (1945).

[137] Shreve, R. N.; Lux, J. H. Monosulfonation of 2-methylnaphthalene. Ind. Eng. Chem. 35: 306-311 (1943).

[138] Sirotenko, A. A. Zh. Prikl. Khim. (Leningrad) 71: 1047 (1998).

[139] Skvarchenko, V. R.; Levina, R. Y.; Chervoneva, L. A. Synthesis of Aromatic Hydrocarbons VIII. Alkyltetrahydronaphthalenes. Vestnik Moskovskogo Universiteta, Ser. Mat.; Mekh.; Astron.; Fiz.; Khim-. 13: 187 (1958).

[140] Smyth, C. P. Microwave absorption and molecular structure in liquids. XVII Dielectric relaxation times and shapes of rigid molecules. Proc. Natl. Acad. Sci. U. S. A. 42: 234-239 (1956).

[141] Streiff, A. J.; Hulme, A. R.; Cowie, P. A.; Krouskop, N. C.; Rossini, F. D. Purification, purity, and freezing points of sixty-four American Petroleum Institute Standard and Research Hydrocarbons. Anal. Chem. 27: 411-415 (1955).

[142] Szafranski, A. M. Solid-liquid equlibrium. Int. DATA Ser.; Sel. Data Mixtures, Ser. A 1: 40-50 (1984).

[143] Von Auwers, K.; Fruhling, A. Justus Liebigs Ann. Chem. 422: 196 (1921).

[144] Wieczorek, S. A.; Kobayashi, R. Vapor pressure measurements of 1-methylnaphthalene, 2-methylnaphthalene and 9,10-dihydrophenanthrene at elevated temperatures. J. Chem. Eng. Data 26: 8-11 (1981).

[145] Yokoyama, C.; Takei, J.; Kumagai, A. Viscosity of mixtures of indole containing 2-methylnaphthalene and isoquinoline under pressure. High Temp. - High Pressures 32: 97-102 (2000). 
[146] Yokoyama, C.; Takei, J.; Kumagai, A. Viscosity of mixtures of indole containing 2-methylnaphthalene and isoquinoline under pressure, Erratum. High Temp. - High Pressures 33: 345-346 (2001).

[147] Adkins, H.; Davis, J. W. Catalytic dehydrogenation of hydroaromatic compounds in benzene II. J. Am. Chem. Soc. 71: 2955-2957 (1949).

[148] Gudzinowicz, B. J.; Campbell, R. H.; Adams, J. S. Thermal conductivity measurements of complex saturated hydrocarbons. J. Chem. Eng. Data 9: 79-82 (1964).

[149] Weissenberger, G.; Henke, R.; Katschinka, H. Binary liquid mixtures: XX Systems with substituting hydronaphthalenes. Z. Anorg. Allg. Chem. 153: 33 (1926).

[150] Baylaucq, A.; Zeberg-Mikkelsen, C. K.; Dauge, P.; Boned, C. Dynamic viscosity and density of heptylbenzene and heptylcyclohexane up to $100 \mathrm{MPa}$. J. Chem. Eng. Data 2002; 47: 997-1002.

[151] Luther, H. Brennst.-Chem. 30: 258-266 (1949).

[152] Mokbel, I.; Rauzy, E.; Loiseleur, H.; Berro, C.; Jose, J. Vapor pressure of 12 alkylcyclohexanes, cyclopentane, butylcyclopentane and trans-decahydronaphthalene down to 0.5 Pa. Fluid Phase Equilib. 108: 103-120 (1995).

[153] Schlenk, W. Justus Liebigs Ann. Chem. 573: 142-162 (1951).

[154] Schmidt, A. W. Physical properties of aliphatic compounds. Ber. Dtsch. Chem. Ges. B75: 1399 (1942).

[155] Schmidt, A. W.; Grosser, A. Physical data of alkyl cyclohexanes. Ber. Dtsch. Chem. Ges. A 73: 930 (1940).

[156] Allinger, N. L.; Coke, J. L. The relative stabilities of cis and trans isomers. 6. The decalins. J. Am. Chem. Soc. 81: 4080-4082 (1959).

[157] Bird, L. H.; Daly, E. F. Trans. Farad. Soc. 35: 588 (1939).

[158] Boord, C. E.; Greenlee, K. W.; Perilstein, W. L.; Derfer, J. M. The synthesis, purification and prop. of hydrocarbons of low mol. wt.; Am. Pet. Inst. Res. Proj. 45,Eleventh Annu. Rep.; Ohio State Univ. (1949).

[159] Cheng, D. C. H.; McCoubrey, J. C.; Phillips, D. G. Critical temperatures of some organic cyclic compounds. Trans. Farad. Soc. 58: 224 (1962).

[160] Chylinski, K.; Stryjek, R. Excess volumes of 1,2,3,4-tetrahydronaphthalene+trans-,and + cis -bicyclo[4.4.4]decane and of quinoline +trans- and +cis-bicyclo[4.4.0] decane, $+1,2,3,4$-tetrahydronaphthalene, and $+\mathrm{n}$-hexadecane at. J. Chem. Thermodyn. 14: 1115 (1982).

[161] Cooper, A. R.; Crowne, C. W. P.; Farrell, P. G. Gas-liquid chromatographic studies of electron-donor-acceptor systems. Trans. Farad. Soc. 63: 447 (1967).

[162] Dauben, W. G.; Hiskey, C. F.; Markhart, A. H. J. Am. Chem. Soc. 73: 1393 (1951).

[163] Polenske, R.; Eisenlohr, F. Chem. Ber. 57: 1639 (1924).

[164] Fenske, M. R.; Myers, H. S.; Quiggle, D. n-Decane-trans-decahydronaphthalene. Binary mixture for determining efficiencies of fractioning columns operating at reduced pressures. Ind. Eng. Chem. 42: 649 (1950).

[165] Foehr, E. G.; Fenske, M. R. Magneto-optic rotation of hydrocarbons. Ind. Eng. Chem. 41: 1956 (1949).

[166] Frezzotti, D.; Goffredi, G.; Bencini, E. Thermal conductivity measurements of cis- and trans-decahydronaphthalene isomers using a steady-state coaxial cylinders method. Thermochim. Acta 265: 119-128 (1995).

[167] Gudzinowicz, B. J.; Campbell, R. H.; Adams, J. S. Specific heat measurements of complex 
saturated hydrocarbons. J. Chem. Eng. Data 8: 201 (1963).

[168] Guenthard, H. H.; Suess, R.; Marti, L.; Furst, A.; Plattner, P. A. Helv. Chim. Acta 34: 959 (1951).

[169] Hibbit, D. C.; Linstead, R. P. Fused carbon rings, Part VII. The preparation of cyclic hydrocarbons from unsaturated tertiary alcohols. The synthesis of cis-9-methyloctalin and -decalin and a proof of the presence of angular methyl. J. Chem. Soc. (London) 470 (1936).

[170] Hogenboom, D. L.; Webb, W.; Dixon, J. A. The low-temperature thermodynamic properties of naphthalene, 1-methylnaphthalene, 2-methylnaphthalene, 1,2,3,4-tetrahydronaphthalene, trans-decahydronaphthalene and cis-decahydronaphthalene. J. Chem. Phys. 46: 2586 (1967).

[171] Huckel, W. Justus Liebigs Ann. Chem. 441: 1 (1925).

[172] Huckel, W. Suom. Kemistil. B 17: 7 (1944).

[173] Huckel, W.; Kumetat, K.; Severin, H. Justus Liebigs Ann. Chem. 518: 184 (1935).

[174] Ipatieff, V. N.; Pines, H. J. Am. Chem. Soc. 59: 56 (1937).

[175] Jasper, J. J. The surface tension of pure liquid compounds. J. Phys. Chem. Ref. Data 1: 841-1009 (1972).

[176] Korosi, G.; Kovats, E. Density and surface tension of 83 organic liquids. J. Chem. Eng. Data 26: 323 (1981).

[177] Kuss, E. Some physical properties of crude oils at high pressure. Erdoel Kohle 6: 266 (1953).

[178] Lauer, J. L.; King, R. W. Anal. Chem. 28: 1697 (1956).

[179] Lozovoi, A. V.; D'yakova, M. K.; Stepantseva, T. G. Some physical constants of hydrocarbon mixtures: II. Zhurnal Obshchei Chim 9: 540-546 (1939).

[180] Lyusternik, V. E.; Zhdanov, A. G. Viscosity of alkanes, alkenes and alkynes in gaseous phase. Teplofiz. Svoistva Veshchestv Mater.; Rabinovich, V. A.; Ed.; Standards Publ.: Moscow 7 (1973).

[181] McCullough, J. P.; Finke, H. L.; Messerly, J. F.; Todd, S. S.; Kincheloe, T. C.; Waddington, G. The low-temperature thermodynamic properties of naphthalene, 1-methylnaphthalene, 2-methylnaphthalene, 1,2,3,4-tetrahydro- naphthalene, trans-decahydronaphthalene and cis-decahydronaphthalene. J. Phys. Chem. 61: 1105-1116 (1957).

[182] Nuzzi, M. Riv. Combust. 38: 211 (1984).

[183] Pak, S. C.; Kay, W. B. Gas-liquid critical temperatures of mixtures. benzene + n-alkanes and hexafluorobenzene + n-alkanes. Ind. Eng. Chem. 11: 255 (1972).

[184] Parks, G. S.; Hatton, J. A. Thermal data on organic compounds. XXIV. The heat capacities, entropies and free energies of cis- and trans-decahydronapthalene. J. Am. Chem. Soc. 71: 2773-2775 (1949).

[185] Parthasarathy, P. S. Ultrasonic velocities in organic liquids. Proceedings - Indian Academy of Sciences, Section A 4: 59 (1936).

[186] Petrov, A. D. Izvestiya Akademii Nauk SSSR, Seriya Khimicheskaya 533 (1941).

[187] Prokopetz, E. I. Zh. Prikl. Khim. (Leningrad) 8: 1214 (1935).

[188] Rank, D. H.; Scott, R. W.; Fenske, M. R. Qualitive and quantitative analysis of hydrocarbon mixtures. Anal. Chem. 14: 816 (1942).

[189] Ruzicka, L.; Koolhaas, D. R.; Wind, A. H. Helv. Chim. Acta 14: 1151 (1931).

[190] Schiessler, R. W.; Herr, C. H.; Rytina, A. W.; Weisel, C. A.; Fischl. F.; McLaughlin, R. L.; Kuehner, H. H. The synthesis and properties of hydrocarbons of high molecular weight-IV. Proc., American Petroleum Inst. 26: 254-302 (1946). 
[191] Seyer, W. F.; Barrow, G. M. The dielectric properties of solid and liquid cis- and transdecahydronaphthalene. J. Am. Chem. Soc. 70: 802-805 (1948).

[192] Seyer, W. F.; Leslie, J. D. The viscosity of cis and trans decahydronaphthalene. J. Am. Chem. Soc. 64: 1912-1916 (1942).

[193] Seyer, W. F.; Mann, C. W. The vapor pressures of cis- and trans-decahydronaphthalene. J. Am. Chem. Soc. 67: 328 (1945).

[194] Seyer, W. F.; Walker, R. D. The densities and surface tensions of cis-and trans-decahydronaphthalene between -30 and 180 K. J. Am. Chem. Soc. 63: 2425 (1941).

[195] Shiohama, Y.; Ogawa, H.; Murakami, S. Molar excess enthalpies of cis-decalin + benzene, + toluene, + isooctane and + heptane at 298.15 K. Fluid Phase Equilib. 32: 249 (1987).

[196] Shiohama, Y.; Ogawa, H.; Murakami, S.; Fujihara, I. Excess molar isobaric heat capacities and isentropic compressibilities of (cis- or trans-decalin + benzene or toluene or isooctane or n-heptane) at 298.15 K. J. Chem. Thermodyn. 20: 1183 (1988).

[197] Sohda, M.; Iwai, Y.; Arai, Y.; Sakoguchi, A.; Ueoka, R.; Kato, Y. Vapor Pressure of cisand trans-Decalins. Netsu Sokutei 17: 131 (1990).

[198] Stokkum, I. H. M. V.; Scherer, T.; Brouwer, A. M.; Verhoeven, J. W. Conformational dynamics of flexibly and semirigidly bridged electron donor-acceptor systems as revealed by spectrotemporal parameterization of fluorescence. J. Phys. Chem. 98: 852-866 (1994).

[199] Streiff, A. J.; Soule, L. F.; Kennedy, C. M.; Janes, M. E.; Sedlak, V. A.; Willingham, C. B.; Rossini, F. D. Purification, purity, and freezing points of twenty-nine hydrocarbons of the API-standard and API-NBS series. Nat. Bur. Stand (U.S.) J. Res. 45 : 173 (1950).

[200] Timmermans, J. Freezing points of organic compounds. VVI New determinations. Bull. Soc. Chim. Belg. 61: 393 (1952).

[201] Zeberg-Mikkelsen, C. K.; Baylaucq, A.; Barrouhou, M.; Boned, C. The effect of stereoisomerism on dynamic viscosity: A study of cis-decalin and trans-decalin versus pressure and temperature. Phys. Chem. Chem. Phys. 5: 1547-1551 (2003).

[202] Zelinskii, N. D.; Titz, I. N.; Fateev, L. Ber. Dtsch. Chem. Ges. A 59: 2580 (1926).

[203] Asinger, F. Chem. Ber. 77: 73 (1944).

[204] Baumgarten, P. Chem. Ber. 75: 977 (1942).

[205] Boord, C. E.; Greenlee, K. W.; Derfer, J. M. The synthesis, purification and prop. of hydrocarbons of low mol. wt.; Am. Pet. Inst. Res. Proj. 45, Twelfth Annu. Rep.; Ohio State Univ. (1950).

[206] Engler, C.; Hofer, H. Das Erdols, Hirtzel Co. Leipzig, Ger 1: 268 (1913).

[207] Forziati, A. F.; Camin, D. L.; Rossini, F. D. Density, refractive index, boiling point, and vapor pressure of eight monoolefin (l-alkene), six pentadiene, and two cyclomonoolefin hydrocarbons. Nat. Bur. Stand. (U.S.) J. Res. 45: 406 (1950).

[208] Geldof, H.; Wibaut, J. P. Recl. Trav. Chim. Pays-Bas 67: 105 (1948).

[209] Gude, M. T.; Rosenthal, D. J.; Teja, A. S. The critical properties of 1-alkenes from 1-pentene to 1-dodecene. Fluid Phase Equilib. 70: 55 (1991).

[210] Hunig, S.; Kiessel, M. Chem. Ber. 91: 380 (1958).

[211] Jasper, J. J.; Kerr, E. R. The othobaric surface tensions and thermodynamic properties of the liquid surfaces of a series of 1-alkenes, c6 to c16, and of decylcyclopentane, decylcyclohexane, and decylbenzene. J. Am. Chem. Soc. 76: 2659 (1954).

[212] Jasper, J. J.; Kring, E. V. The isobaric surface tensions and thermodynamic properties of the surfaces of a series of n-alkanes, c5 to c18, 1-alkenes, c6 to c16, and of n-decylcyclopentane, n-decylcyclohexane and n-decylbenz. J. Phys. Chem. 59: 1019 
(1955).

[213] Jeffery, G. H.; Vogel, A. I. Physical properties and chemical constitution: xvi ethylenic compounds. J. Chem. Soc. (London) 658-673 (1948).

[214] Krafft, F. Preparation of higher olefins, especially dodecene $\mathrm{c}(12) \mathrm{h}(24)$, tetradecene $\mathrm{c}(14) \mathrm{h}(28)$, cetene or hexadecene $\mathrm{c}(16) \mathrm{h}(32)$ and octadecene $\mathrm{c}(18) \mathrm{h}(36)$. Ber. Dtsch. Chem. Ges. 16: 3018-3024 (1883).

[215] Krassilchik, A. Rev. Inst. Fr. Pet. Ann. Combust. Liq. 10: 923 (1935).

[216] Labarre, J. F. Contribution to the study of magneto-optics of bonds between atoms in aliphatic hydrocarbons. Ann. Chim. (Paris) 8: 45-83 (1963).

[217] Lenneman, W. L.; Hites, R. D.; Komarewsky, V. I. Sulfuric acid-catalyzed alkylation of benzene with high-molecular 1-alkenes. J. Org. Chem. 19: 463 (1954).

[218] Maman, A. Publ. Sci. Tech. Minist. Air (Fr.) 66: 32 (1935).

[219] McCullough, J. P.; Finke, H. L.; Gross, M. E.; Messerly, J. F.; Waddington, G. Low temperature calorimetric studies of seven 1-olefins: Effect of orientational disorder in the solid state. J. Phys. Chem. 61: 289 (1957).

[220] Mukhamedzyanov, G. K.; Usmanov, A. G. Thermal conductivity of liquid organic compounds. Teplo i Massoperenos 7: 518 (1968).

[221] Petrov, A. A.; Sergienko, S. R.; Tsedilina, A. L.; Egorov, Y. P. Isomeric conversions of unsaturated hydrocarbons, c(12)-c(16). Khim. Tech. Topliv Masel 1: 26-32 (1956).

[222] Schmidt, A. W.; Schoeller, V.; Eberlein, K. Uber physikalische Daten von 1-Olefinen und n-Paraffinen. Berichte der Deutschen Chemischen Geseilschaft 74B: 1313-1324 (1941).

[223] Tilicheev, M. D.; Peshkov, V. P.; Yuganova, S. A. Determination of the purity and identification of 1-alkenes by means of a thermal method. Zh. Anal. Khim. 4: 298 (1949).

[224] Urry, W. H.; Stacey, F. W.; Huyser, E. S.; Juveland, O. O. The peroxide- and light-induced additions of alcohols to olefins. J. Am. Chem. Soc. 76: 450 (1954).

[225] Wibaut, J. P.; Geldof, H. Accurate values of the specific gravities and the refractive indices of a series of alkenes with terminal double bond. Recl. Trav. Chim. Pays-Bas 65: 125 (1946).

[226] Zafiriadis, Z.; Mastagli, P. C. R. Hebd. Seances Acad. Sci. 238: 821 (1954).

[227] Kozacik, A. P.; Reid, E. E. Lengthening carbon chains by three units assay of primary bromides from the addition of hydrogen bromide. J. Am. Chem. Soc. 60: 2436-2438 (1938).

[228] Lagemann, R. T.; McMillan, D. R.; Woolsey, M. Ultrasonic velocity in a series of 1-olefins. J. Chem. Phys. 16: 247 (1948).

[229] Pictet, A.; Potok, J. The distillation of sodium stearate and oleate under reduced pressure and the origin of petroleum. Helv. Chim. Acta 2: 501 (1919).

[230] Schiessler, R. W. Am. Pet. Inst. Res. Proj. 42, Twelfth Meeting (1947).

[231] Ambrose, D.; Cox, J. D.; Townsend, R. The critical temperatures of forty organic compounds. Trans. Farad. Soc. 56: 1452 (1960).

[232] Aucejo, A.; Cruz Burguet, M.; Muñoz, R.; Marques, J. L. Densities, viscosities, and refractive indices of the binary liquid systems n-alkanes + isomers of hexane at $298.15 \mathrm{~K}$. J. Chem. Eng. Data 40: 871-874 (1995).

[233] Avery, W. H.; Ellis, C. F. J. Chem. Phys. 10: 10 (1942).

[234] Bazhulin, P. A.; Bokstein, M. L.; Liberman, A. L.; Lukina, M. Y.; Margolis, E. I.; Solovova, O. P.; Kazanskii, B. A. Optical methods for studying hydrocarbons, III. The combined scattering spectrum of paraffins. Izvestiya Akademii Nauk SSSR, Seriya 
Khimicheskaya 198 (1943).

[235] Bishop, J. W.; Burk, R. E.; Lankelma, H. P. The action of aluminum bromide on paraffin hydrocarbons, II. Branched chain hexanes. J. Am. Chem. Soc. 67: 914 (1945).

[236] Boord, C. E. Oil Gas J. 41: 188 (1942).

[237] Brame, J. S. S.; Hunter, T. G. Composition of cracked distillates. J. Inst. Petroleum Tech. 13: 794 (1927).

[238] Brazier, D. W.; Freeman, G. R. The effects of pressure on the density, dielectric constant, and viscosity of several hydrocarbons and other organic liquids. Can. J. Chem. 47: 893-899 (1969).

[239] Brewster, J. H.; Patterson, J. W.; Fidler, D. A. Reductions at metal surfaces, III. Clemensen reduction of some sterically-hindered ketones. J. Am. Chem. Soc. 76: 6368 (1954).

[240] Brooks, D. B.; Howard, F. L.; Crafton, H. C. Physical Properties of some purified aliphatic hydrocarbons. Nat. Bur. Stand. (U.S.) J. Res. 24: 33 (1940).

[241] Chavanne, G.; van Risseghem, H. Bull. Soc. Chim. Belg. 31: 87 (1922).

[242] Chavanne, G. The constituents of the fraction of a Borneo petroleum which distills between 37 and 81 degrees. Bull. Soc. Chim. Belg. 31: 331 (1922).

[243] Chen, S. S.; Zwolinski, B. J. Excess thermodynamic functions of binary mixtures of normal and isomeric alkanes (C5 and C6). J. Chem. Soc.; Faraday Trans. 2 70: 1133-1142 (1974).

[244] Compostizo, A.; Crespo Colin, A.; Rubio, R. G.; Diaz Pena, M. Thermodynamics of mixtures with a hexane isomer: excess volumes of 1- chlorohexane with a hexane isomer at 298.15 K. J. Chem. Soc.; Faraday Trans. 1 83: 819 (1987).

[245] Cramer, P. L.; Mulligan, M. J. The preparation of the isomeric hexanes. J. Am. Chem. Soc. 58: 373 (1936).

[246] Denyer, R. L.; Fidler, F. A.; Lowry, R. A. Azeotrope formation between thiols and hydrocarbons. Ind. Eng. Chem. 41: 2727-2737 (1949).

[247] Derfer, J. M.; Greenlee, K. W.; Boord, C. E. A New synthesis of monoalkylcyclobutanes: reduction of neopentyl type tribromides. J. Am. Chem. Soc. 71: 175 (1949).

[248] Desty, D. H.; Whyman, B. H. F. Anal. Chem. 29: 320 (1957).

[249] Dixon, J. A. Binary solutions of saturated hydrocarbons. J. Chem. Eng. Data 4: 289 (1959).

[250] Douslin, D. R.; Huffman, H. M. Low-temperature thermal data on the five isomeric hexanes. J. Am. Chem. Soc. 68: 1704 (1946).

[251] Eicher, L. D.; Zwolinski, B.J. Molecular structure and shear viscosity. Isomeric hexanes. J. Phys. Chem. 76: 3295-3300 (1972).

[252] Felsing, W. A.; Watson, G. M. The pressure-volume-temperature relations of 2,2-dimethylbutane. J. Am. Chem. Soc. 65: 1889-1891 (1943).

[253] Fenske, M. R.; Braun, W. G.; Wiegand, R. V.; Quiggle, D.; McCormick, R. H.; Rank, D. H. Raman spectra of hydrocarbons. Anal. Chem. 19: 700-765 (1947).

[254] Finke, H. L. C.; M. R.; Frey, F. E.; and Aston, J. G. Solid solution studies i. equilibria in the binary systems 2,2-dimethyl butane-2,3-dimethylbutane and 2,2-dimethylbutane-cyclopentane. J. Am. Chem. Soc. 69: 1501 (1947).

[255] Fischer, L. O. Research in stoichiometry: IV the heat of fusion and the polymorphism of organic compounds. Bull. Soc. Chim. Belg. 49: 129 (1940).

[256] Fomin, W.; Sochanski, N. Chem. Ber. 46: 244 (1913).

[257] Forziati, A. F. Am. Pet. Inst. Res. Proj. 6, Nat. Bur. Stand. (U.S.) (1943).

[258] Forziati, A. F.; Glasgow, A. R.; Willingham, C. B.; Rossini, F. D. Specification and 
properties of 29 paraffin, 4 alkylcyclopentanes, 10 alkylcyclohexanes and 8 alkylbenzene hydrocarbons. Nat. Bur. Stand. (U.S.) J. Res. 36: 129 (1946).

[259] Funk, E. W.; Chai, F.-C.; Prausnitz, J. M. Thermodynamic properties of binary liquid mixtures containing aromatic and saturated hydrocarbons. J. Chem. Eng. Data 17: 24-27 (1972).

[260] Genco, J. M.; Teja, A. S.; Kay, W. B. Study of the critical and azeotropic behavior of binary mixtures I critical states of perfluoromethylcyclohexane + isomeric hexane systems. J. Chem. Eng. Data 25: 350 (1980).

[261] Glasgow, A. R.; Rossini, F. D. Am. Pet. Inst. Res. Proj. 6 Nat. Bur. Stand. (U.S.) (1943).

[262] Glasgow, A. R.; Murphy, E. T.; Willingham, C. B.; Rossini, F. D. Purification, purity, and freezing points of 31 hydrocarbons of the api- nbs series. Nat. Bur. Stand. (U.S.) J. Res. 37: 141 (1946).

[263] Griskey, R. G.; Canjar, L. N. Compressibilities of 2-methylpentane and 2,2-dimethylbutane. J. Chem. Eng. Data 9: 271 (1964).

[264] Griswold, J.; van Berg, C. F.; Kasch, J. E. Ind. Eng. Chem. 35: 854 (1943).

[265] Grummitt, O.; Sensel, E. E.; Smith, W. R.; Burk, R. E.; Lankelma, H. P. The action of aluminum bromide on paraffin hydrocarbons I. n-hexane and n-heptane. J. Am. Chem. Soc. 67: 910 (1945).

[266] Haensel, V.; Ipatieff, W. Selective demethylation of paraffin hydrocarbons. J. Am. Chem. Soc. 68: 345 (1946).

[267] Hickman, J. B. Solubility of isomeric hexanes in perfluoroheptane. J. Am. Chem. Soc. 66: 6154-6156 (1955).

[268] Hicks-Brunn, M. M.; Bruun, J. H.; Faulconer, W. B. M. Isolation of 2,2-dimethylbutane from natural gas and determination of its physical properties. J. Am. Chem. Soc. 61: 3099-3101 (1939).

[269] Hoog, H.; Smittenberg, J.; Visser, G. H. Composition of the primary polymerization prod. of propene and butenes. Ile Congr. Mondial Pet 2.;Phys Chem. Raffin-age 489 (1937).

[270] Kay, W. B. The vapor pressures and saturated liquid and vapor densities of the isomeric hexanes. J. Am. Chem. Soc. 68: 1336 (1946).

[271] Kay, W. B.; Young, C. L. Gas-liquid critical properties. Tetradecafluoro-methylcyclohexane( perfluoromethylcyclohexane)-2,2-dimethylbutane. Int. DATA Ser.; Sel. Data Mixtures, Ser. A 1: 58 (1974).

[272] Kilpatrick, J. E.; Pitzer, K. S. The thermodynamics of 2,2-dimethylbutane, including the heat capacity, heat of transitions, fusion and vaporization and the entropy. J. Am. Chem. Soc. 68: 1066 (1946).

[273] Kimura, F.; Benson, G. C. Excess enthalpies of binary mixtures of 1-hexanol with hexane isomers at 298.15 K. J. Chem. Eng. Data 26: 317-318 (1981).

[274] Kimura, F.; Benson, G. C. Excess volume of binary mixtures of 1-hexanol with hexane isomers at 298.15 5 K. J. Chem. Eng. Data 28: 157-160 (1983).

[275] Kimura, F.; Benson, G. C. Excess volumes of binary mixtures of 2-ethyl-1-butanol with hexane isomers at 298.15 K. Fluid Phase Equilib. 16: 77-86 (1984).

[276] Kishner, N. Trimethylethylmethane from pinacolin. Zhurnal Russ. Fiz.-Khim. O.-va, Chast Khim. 47: 1111 (1915).

[277] Kuss, E.; Pollman, P. Z. Phys. Chem. (Leipzig) 68: 205 (1969).

[278] Lambert, J. D.; Cotton, K. J.; Pailthorpe, M. W.; Robinson, A. M.; Scrivins, J.; Vale, W. R. F.; Young, R. M. Transport properties of gaseous hydrocarbons. Proc. R. Soc. London, Ser. 
A 231: 280-290 (1955).

[279] Liberman, A. L.; Lukina, M. Y.; Solovova, O. P.; Kazanskii, B. A. The synth. of paraffins containing a quaternary c atom by means of Z alkyls. Doklady Akademii Nauk SSSR 40: 70 (1943).

[280] Lichtenfels, D. H.; Fleck, S. A.; Burow, F. H. Anal. Chem. 27: 1510 (1955).

[281] Maman, A. The preparation and several physicochemical properties of hexane and its isomers. C. R. Hebd. Seances Acad. Sci. 198: 1323 (1934).

[282] Maman, A. The hexanes and some related hydrocarbons. Publ. Sci. Tech. Minist. Air (Fr.) 66: 55 (1935).

[283] Marker, R. E.; Oakwood, T. S. Hexamethylethane and tetraalkylmethanes. J. Am. Chem. Soc. 60: 2598 (1938).

[284] Markownikov, W. Trimethylethylmethane. Chem. Zentr. ii: 472 (1899).

[285] McArdle, E. H.; Robertson, A. E. Solvent properties of isomeric paraffins. Ind. Eng. Chem. 34: 1005 (1942).

[286] Moldavskii, L; Nizovkina, T. V. Hydrogenation of oxygent-contining compounds, III. Preparation of 2,3-dimethylbutane from pinacalone. Zhurnal Obshchei Khim 10: 1183 (1940).

[287] Nicolini, E.; Laffitte, P. Vapor densities and latent heats of vaporization of pure org. liquids. C. R. Hebd. Seances Acad. Sci. 229: 935-936 (1949).

[288] Noller, C. R. The prep. of zinc alkyls and their use in the synthesis of hydrocarbons. J. Am. Chem. Soc. 594 (1929).

[289] Oberfell, G. G.; Frey, F. E. Oil Gas J. 38: 70 (1939).

[290] Paz Andrade, M. I. Int. DATA Ser.; Sel. Data Mixtures, Ser. A 2: 103 (1973).

[291] Pichler, H.; Ziesecke, K. H.; Titzenthaler, E. The composition of hydrocarbons from isosynthesis. Brennst.-Chem. 30: 333 (1949).

[292] Rodger, A. J.; Hsu, C. C.; Furter, W. F. Vapor-liquid equilibria for 23 carbon tetrachloride-hydrocarbon syst. J. Chem. Ecol. 14: 362 (1969).

[293] Sakiadis, B. C.; Coates, J. Studies of thermal conductivity of liquids, Parts I and II. AIChE J. 1: 275-288 (1955).

[294] Sayegh, S. G.; Ratcliff, G. A. Excess Gibbs energies of binary systems of isopentanol and n-pentanol with hexane isomers at $25 \mathrm{deg}$. C: Measurement and prediction by analytical group solution model. J. Chem. Eng. Data 21: 71 (1976).

[295] Schmerling, L.; Friedman, B. S.; Ipatieff, V. N. Notes on preparation and properties of some aliphatic hydrocarbons. J. Am. Chem. Soc. 62: 2446-2449 (1940).

[296] Serijan, K. T.; Spurr, R. A.; Gibbons, L. C. The system cyclopentane-neohexane-aniline. J. Am. Chem. Soc. 68: 1763-1764 (1946).

[297] Seubold, F. H. The cyclohexyl and cyclopentylmethyl radicals. J. Am. Chem. Soc. 76: 3732 (1954).

[298] Shen, W.-G.; Williamson, A. G. Enthalpies of mixing of ternary alkane mixtures with branched chain components. Can. J. Chem. 66: 904-907 (1988).

[299] Smittenberg, J.; Hoog, H.; Henkes, R. A. Freezing points of a number of pure hydrocarbons of the gasoline boiling range and of some of their binary mixtures. J. Am. Chem. Soc. 60: 17 (1938).

[300] Smutny, E. J.; Bondi, A. Di-t-Butyl ether: Strain energy and physical properties. J. Phys. Chem. 65: 546-550 (1961).

[301] Stull, D. R. A Semi-micro calorimeter for measuring heat capacities at low temp. J. Am. 
Chem. Soc. 59: 2726 (1937).

[302] Timmermans, J. Investigation of the freezing point of organic substances VII. Bull. Soc. Chim. Belg. 31: 389 (1922).

[303] Tooke, J. W.; Aston, J. G. Solid solutions in hydrocarbon systems. J. Am. Chem. Soc. 67: 2275 (1945).

[304] Tsvetkov, O. B. Thermal conductivity of freon C318 along the saturation boundary. Khol. Tekh. 44: 61 (1967).

[305] Van Risseghem, H. Synthesis of trimethylethylmethane. Bull. Soc. Chim. Belg. 31: 62-66 (1922).

[306] Van Wijk, W. R.; Versteeg, J. M. Viscosity of pure hydrocarbons. Ile Congr. Mondial Pet 2.;Phys Chem. Raffin-age 955 (1937).

[307] Vilim, O. Thermal conductivity of hydrocarbons. Collection Czechoslov, Chem. Commun. 25: 993-999 (1960).

[308] Waddington, G.; Douslin, D. R. Experimental vapor heat capacities and heats of vaporization of n-hexane and 2,2-dimethylbutane. J. Am. Chem. Soc. 69: 2275 (1947).

[309] Westerdijk, J. B.; Waterman, H. I.; Span, H. F. O.; Booij, H.; van Nes, K. J. Inst. Pet. 36: (1950) 281.

[310] Wibaut, J. P.; Gitsels, H. P. L. Refractometric constants of 3,3-dimethyl-1-butene. Recl. Trav. Chim. Pays-Bas 60: 241 (1941).

[311] Wibaut, J. P.; Hoog, H.; Langedijk, S. L.; Overhoff, J.; Smittenberg, J.; Benninga, N.; Bouman, G. P.; van Dijk, H.; Gaade, W.; Geldof, H.; Hackmann, J. T.; Jonker, E. W.; Paap, T.; Zuiderweg, F. J. Study on the preparation and the physical constants of a number of alkanes and cycloalkanes. Recl. Trav. Chim. Pays-Bas 58: 329 (1939).

[312] Willingham, C. B.; Taylor, W. J.; Pignocco, J. M.; Rossini, F. D. Vapor pressures and boiling points of some paraffin, alkylcyclopentane, alkylcyclohexane and alkylbenzene hydrocarbons. Nat. Bur. Stand. (U.S.) J. Res. 35: 219 (1945).

[313] Wojciechowski, M. Some physical constants of a few hydrocarbons and their structural isomers. Proc. Am. Acad. Arts Sci 73: 361 (1940).

[314] Young, C. L. Int. DATA Ser.; Sel. Data Mixtures, Ser. A 1: 48 (1974).

[315] Zhang, D.; Benson, G. C.; Lu, B. C. Y. Excess volume of n-decane + a hexane isomer) at 298.15 K. J. Chem. Thermodyn. 18: 619 (1986).

[316] Ait-Kaci, A.; Merlin, J. C. Int. DATA Ser.; Sel. Data Mixtures, Ser. A 1: 70 (1979).

[317] Aminabhavi, T. M.; Gopalkrishma, B. Densities, viscosities, refractive indices, and speeds of sound of the binary mixtures of bis(2-methoxyethyl) ether with nonane, decane, dodecane, tetradecane, and hexadecane at 298.15, 308.15, and 318.15 K. J. Chem. Eng. Data 39: 529-534 (1994).

[318] Anselme, M. J.; Gude, M.; Teja, A. S. The critical temperatures and densities of the n-alkanes from pentane to octadecane. Fluid Phase Equilib. 57: 317-326 (1990).

[319] Aracil, J.; Rubio, R. G.; Caceres, M.; Diaz Pena, M.; Renuncio, J. A. R. Excess properties of the hexafluorobenzene-n-hexadecane and hexafluorobenzene-benzene-n-hexadecane systems at 298.15 K. Fluid Phase Equilib. 31: 71-87 (1986).

[320] Aracil, J.; Rubio, R. G.; Renuncio, J. A. R.; Diaz Pena, M. Vapour-liquid equilibrium of n-tetradecane and of n-hexadecane with hexafluorobenzene and with hexafluorobenzene + benzene at 323.15 K. Ber. Bunsenges. Phys. Chem. 91: 603-611 (1987).

[321] Aralaguppi, M. I.; Aminabhavi, T. M.; Balundgi, R. H.; Joshi, S. S. Thermodynamic interactions in mixtures of bromoform with hydrocarbons. J. Phys. Chem. 95: 5299-5308 
(1991).

[322] Arenosa, R. L.; Rubio, R. G.; Menduina, C.; Diaz Pena, M. Excess enthalpies of binary mixtures of ethylbenzene + n-alkanes. J. Chem. Eng. Data 30: 24-26 (1985).

[323] Asfour, A.-F. A.; Siddique, M. H.; Vavanellos, T. D. Density-composition data for eight binary systems containing toluene or ethylbenzene and C(8)-C(16) n-alkanes at 293.15, 298.15, 308.15, and 313.15 K. J. Chem. Eng. Data 35: 192-198 (1990).

[324] Assael, M. J.; Charitidou, E.; Karagiannidis, L. The thermal conductivity of n-hexadecane + ethanol and n-decane + butanol mixtures. Int. J. Thermophys. 12: $491-500$ (1991).

[325] Aucejo, A.; Cruz Burguet, M.; Muñoz, R.; Marques, J. L. Densities, viscosities, and refractive indices of some n-alkane binary liquid systems at 298.15 K. J. Chem. Eng. Data 40: 141-147 (1995).

[326] Awwad, A. M.; North, A. M.; Pethrick, R. A. J. Chem. Soc.; Faraday Trans. 1 79: 2333 (1983).

[327] Awwad, A. M.; Allos, E. I. Volumes of mixing and the isomeric effect. Part 1. Nonane isomers with n-nonane and n-hexadecane. J. Solution Chem. 16: 465-474 (1987).

[328] Awwad, A. M.; Pethrick, R. A. Isentropic compressibilities of hydrocarbons and their mixtures. Mixtures of linear and branched-chain alkanes. J. Chem. Thermodyn. 16: 131-136 (1984).

[329] Awwad, A. M.; Salman, M.A. Excess Molar Volumes and Viscosities of Binary Mixtures of Cyclohexanes and n-Alkane at 298.15 K. Fluid Phase Equilib. 25: 195-208 (1986).

[330] Awwad, A. M.; Salman, M. A. Volume of mixtures of nonane isomers with normal nonane and normal hexadecane at $298.15 \mathrm{~K}$; an interpretation in terms of the Flory-Patterson theory. Fluid Phase Equilib. 31: 105-115 (1986).

[331] Awwad, A. M.; Al-Azzawi, S. F.; Salman, M. A. Volumes and viscosities of benzene + n-alkane mixtures. Fluid Phase Equilib. 31: 171-182 (1986).

[332] Awwad, A. M.; Al-Nidawy, N. K.; Salman, M. A.; Hassan, F. A. Molar excess volumes of binary mixtures of ethylbenzene with n-alkanes at $298.15 \mathrm{k}$; an interpretation in termos of the prigogin-flory- patterson model. Thermochim. Acta 114: 337 (1987).

[333] Awwad, A. M.; Jbara, K. A.; Al-Dujaili, A. H. Excess volumes of n-pentylacetate with alkanes, cycloalkanes and aromatics at 303.15 K. Fluid Phase Equilib. 46: 259-265 (1989).

[334] Banipal, T. S.; Garg, S. K.; C.; A. J. Heat capacities and densities of liquid n-octane, n-nonane, n-decane, and n-hexadecane at temperatures from $318.15 \mathrm{~K}$ to $373.15 \mathrm{~K}$ and at pressures up to $10 \mathrm{MPa}$. J. Chem. Thermodyn. 23: 923-931 (1991).

[335] Banos, I.; Sanchez, F.; Perez, P.; Valero, J.; Gracia, M. Vapor pressures of 1-butanol with n-hexadecane between 293.18 and 323.18 K. Description of 1-butanol + n-alkane systems by ERAS model. Fluid Phase Equilib. 81: 165-174 (1992).

[336] Barber, G. W.; English, J. Reaction of 3,5-Dibromocyclopentene with Grignard reagents. J. Am. Chem. Soc. 73: 746-749 (1951).

[337] Behrends, R.; Kaatze, U. Structural isomerization and molecular motions of liquid n-alkanes. Ultrsonic and high-frequency shear viscosity relaxation. J. Phys. Chem. A104: 3269-3275 (2000).

[338] Benson, G. C.; Handa, Y. P. Ultrasonic speeds and isentropic compressibilities for (decan-1-ol + n-alkane) at 298.15 K. J. Chem. Thermodyn. 13: 887-896 (1981).

[339] Berger, G. Recl. Trav. Chim. Pays-Bas 57: 1029 (1938).

[340] Bhattacharyya, S. N.; Trejo Rodriguez, A.; Andreoli-Ball, L.; Patterson, D. Int. DATA Ser.; Sel. Data Mixtures, Ser. A 1: 47 (1982). 
[341] Boelhouwer, J. W. M. PVT Relations of five liquid n-alkanes. Physica (Amsterdam) (1960) 26: 1021-1028.

[342] Bogatov, G. F.; Rastorguev, Y. L.; Grigor'ev, B. A. Thermal conductivity of normal hydrocarbons at high pressures and temperatures (in Russian). Khim. Tech. Topliv Masel (1969) 9: 31-33.

[343] Bradley, R. S.; Shellard, A. D. The rate of evaporation of droplets. III. Vapour pressures and rates of evaporation of straight-chain paraffin hydrocarbons. Proc. R. Soc. London, A (1949) 198: 239.

[344] Bridgman, P. W. Further rough compressions to 40,000 kg/sq. cm, especially certain liquids. Proc. Am. Acad. Arts Sci. 77: 129-146 (1949).

[345] Bronsted, J. N.; Koefoed, J. Mat.-Fiz. Me. -K. Dan. Vidensk. Selsk. 22: 32 (1946).

[346] Calingaert, G.; Beatty, H. A.; Kuder, R. C.; Thomson, G. W. Homologous series of alkanes density and its temperature coefficient. Ind. Eng. Chem. 33: 103 (1941).

[347] Camin, D. L.; Forziati, A. F.; Rossini, F. D. Physical properties of n-hexadecane, n-decylcyclopentane, n-decylcyclohexane, 1-hexadecene and n-decylbenzene. J. Chem. Phys. 58: 440 (1954).

[348] Carey, P. C.; Smith, J. C. Higher aliphatic compounds: Part III. The preparation of paraffins. J. Chem. Soc. 346-347 (1933).

[349] Celda, B.; Campos, A.; Figueruelo, J. E.; Horta, A. Excess Gibbs function and excess volume of n-alkane (1) + 2-butanone (2) systems at $20^{\circ} \mathrm{C}$. J. Phys. Chem. 90: 1137-1143 (1986).

[350] Chang, J. S.; Lee, M. J.; Lin, H.-M. Densities of binary mixtures of hexadecane with $\mathrm{m}$-xylene and tetralin from $333 \mathrm{~K}$ to $413 \mathrm{~K}$ and pressures up to $30 \mathrm{MPa}$. J. Chem. Eng. Data 43: 233-237 (1998).

[351] Chawla, B.; Parkash, R.; Suri, S. K. A systematic study on volumetric interactions of cyclohexanone with various aliphatic hydrocarbons. Can. J. Chem. 61: 1647 (1983).

[352] Chevalier, J. L. E.; Petrino, P. J.; Gaston-Bonhomme, Y. H. Viscosity and density of some aliphatic, cyclic, and aromatic hydrocarbons binary liquid mixtures. J. Chem. Eng. Data 35: 206-212 (1990).

[353] Chylinski, K.; Stryjek, R. Viscosity of binary bicyclic compounds - hexadecane systems. Pol. J. Chem. 54: 1797-1804 (1980).

[354] Cooper, E. F.; Asfour, A. A. Densities and kinematic viscosities of some c6-c16 n-alkane binary liquid systems at 293.15 K. J. Chem. Eng. Data 36: 285-288 (1991).

[355] Coursey, B. M.; Heric, E. L. Viscosity of some binary systems of hexadecane and normal chloroalkanes. J. Chem. Eng. Data 14: 426-430 (1969).

[356] Deanesly, R. M.; Carleton, L. T. Physical constants of the normal paraffin hydrocarbons. J. Phys. Chem. 45: 1104 (1941).

[357] DeLorenzi, L.; Fermeglia, M.; Torriano, G. Densities and viscosities of 1,1,1-trichloroethane + paraffins and + cycloparaffins at 298.15 K. J. Chem. Eng. Data 39: 483-487 (1994).

[358] Dernini, S.; Polcaro, A. M.; Ricci, P. F.; Marongiu, B. Thermodynamic properties of binary mixtures containing cycloalkanones. 2. Excess volumes of cycloalkanones + n-alkanes. J. Chem. Eng. Data 32: 194-195 (1987).

[359] Diaz Pena, M.; Menduina, C. Excess enthalpies at 298.15k of binary mixtures of benzene with n-alkanes. J. Chem. Thermodyn. 6: 387 (1974).

[360] Diaz Pena, M.; Nunez Delgado, J. Excess volumes at $323.15 \mathrm{~K}$ of binary mixtures of 
benzene with n-alkanes. J. Chem. Thermodyn. 7: 201 (1975).

[361] Diaz Pena, M.; Tardajos, G. Isothermal compressibilities of n-alkanes and benzene. J. Chem. Thermodyn. 10: 19-24 (1978).

[362] Drahowzal, F. Monatsh. Chem. 82: 767 (1951).

[363] Ducoulombier, D.; Zhou, H.; Boned, C.; Peyrelasse, J.; Saint-Guirons, H.; Xans, P. Pressure (1-1000 bars) and temperature (20-100C) dependence of the viscosity of liquid hydrocarbons. J. Phys. Chem. 90: 1692-1700 (1986).

[364] Dymond, J. H.; Harris, K. R. The temperature and density dependence of the self-diffusion coefficient of n-hexadecane. Mol. Phys. 75: 461-466 (1992).

[365] Dymond, J. H.; Young, K. J. Transport properties of nonelectrolyte liquid mixtures- i. viscosity coefficients for n-alkane mixtures at saturation pressure from 283 to $378 \mathrm{~K}$. Int. J. Thermophysics 1: 331-344 (1980).

[366] Dymond, J. H.; Young, K. J.; Isdale, J. D. Transport properties of nonelectrolyte liquid mixtures-ii. viscosity coefficients for the n-hexane $+\mathrm{n}$-hexadecane system at temperatures from 25 to $100 \mathrm{C}$ at pressures up to the freezing pressure or $500 \mathrm{MPa}$. Int. J. Thermophys. 1: 345-373 (1980).

[367] Evans, E. B. The viscosities of hydrocarbons. Parts I-III. J. Inst. Petroleum Tech. 24: 38 (1938).

[368] Fenby, D. V.; Khurma, J. R.; Konner, Z. S.; Block, T. E.; Knobler, C. M.; Reeder, J.; Scott, R. L. Isomer effects in mixtures of hydrocarbons: Some experimental excess volumes and enthalpies. Aust. J. Chem. 33: 1927 (1980).

[369] Ferhat-Hamida, Z.; Philippe, R. Int. DATA Ser.; Sel. Data Mixtures, Ser. A 1979; 1: 17.

[370] Fermeglia, M.; Torriano, G. Density, viscosity, and refractive index for binary systems of n0C16 and four nonliner alkanes at 298.15 K. J. Chem. Eng. Data 44: 965-969 (1999).

[371] Findenegg, G. H. Density and expansion coefficient of some liquid alkanes. Monatsh. Chem. 101: 1081-1088 (1970).

[372] Finke, H. L.; Gross, M. E.; Waddington, G.; Huffman, H. M. Low-temperature thermal data for the nine normal paraffin hydrocarbons from octane to hexadecane. J. Am. Chem. Soc. 76: 333-341 (1954).

[373] Fox, H. W.; Hare, E. F.; Zisman, W. A. Wetting properties of organic liquids on high-energy surfaces. J. Phys. Chem. 59: 1097 (1955).

[374] Francis, F.; Wood, N. E. The boiling points of some higher aliphatic n-hydrocarbons. J. Chem. Soc. (London) 1420-1423 (1926).

[375] Gensler, W. J.; Mahadevan, A. P. Hexadecatriyne-5,8,11. J. Am. Chem. Soc. 78: 167 (1956).

[376] Glaser, M.; Peters, C. J.; van der Kooi, H. J.; Lichtenthaler, R. N. Phase equilibria of (methane $+\mathrm{n}$-hexadecane) and (p, V(m), T) of n-hexadecane. J. Chem. Thermodyn. 17: (1985) 803-815.

[377] Gouel, P. Correlations entre la composition des melanges d'hydrocarbures et leurs proprietes thermodynamiques. Bulletin des centres de recherches exploration-production Alf-Aquitaine 2: 419-467 (1978).

[378] Graaf, G. H.; Smit, H. J.; Stamhuis, E. J.; Beenackers, A. A. C. M. Gas-liquid solubilities of the methanol synthesis components in various solvents. J. Chem. Eng. Data 37: 146 (1992).

[379] Granovskaya, A. A. Determination of the vapor pressure of normal hydrocarbons (pentadecane and hexadecane). Vestnik Moskovskogo Universiteta, Ser. Fiz.-Mat. 
Estestv.Nauk 7: 47 (1952).

[380] Griot, A.; Philippe, R.; Merlin, J. C. Thermal compression coeff. and expansion coeff. at 298.15K for a series of pyridine derivatives. J. Chim. Phys.- Chim. Biol. 79: 671 (1982).

[381] Griot, A.; Philippe, R.; Merlin, J. C. Thermal pressure and expansion coefficients and derived thermodynamic properties at $298.15 \mathrm{~K}$ of binary mixtures of methylcyclohexane and linear alkanes. J. Chim. Phys.- Chim. Biol. 80: 507 (1983).

[382] Grolier, J.-P. E.; Inglese, A.; Roux, A. H.; Wilhelm, E. Thermodynamics of (1-chloronaphthalene $+n$-alkane): excess enthalpies, excess volumes and excess heat capacities. Ber. Bunsenges. Phys. Chem. 85: 768-772 (1981).

[383] Heric, E. L.; Brewer, J. G. Viscosity of some binary liquid nonelectrolyte mixtures. J. Chem. Eng. Data 12: 574-583 (1967).

[384] Heric, E. L.; Brewer, J. G. Refraction in some binary liquid nonelectrolyte mixtures. J. Chem. Eng. Data 16: 313-316 (1971).

[385] Heric, E. L.; Coursey, B. M. Densities and refraction in some binary systems of hexadecane and normal chloroalkanes at $25^{\circ} \mathrm{C}$. J. Chem. Eng. Data 16: 185-187 (1971).

[386] Holmen, R.; Lamvik, M.; Melhus, O. Measurements of the thermal conductivitites of solid and liquid unbranched alkanes in the c-16-to c-19 range during phase transition. Int. J. Thermophys. 23: 27-39 (2002).

[387] Holzapfel, K.; Gotze, G.; Kohler, F. Int. DATA Ser.; Sel. Data Mixtures, Ser. A 1: 43 (1986).

[388] Holzapfel, K.; Goetze, G.; Kohler, F. Volume and isothermal compressibility of oxolane + some normal alkane (C5 - C16). Int. DATA Ser.; Sel. Data Mixtures, Ser. A 4: 263-268 (1987).

[389] Holzapfel, K.; Goetze, G.; Demiriz, A. M.; Kohler, F. Volume and isothermal compressibility of some normal alkanes $(\mathrm{C} 5-\mathrm{C} 16)+2,3$-dimethylbutane, + methylcyclopentane, + butylcyclohexane, + benzene, $+2-$ propanone, or + tetrachloromethane. Int. DATA Ser.; Sel. Data Mixtures, Ser. A 1: 30-56 (1987).

[390] Ivanov, D.; Ivanov, C.; Stoianova-Ivanova, B. Composition of stearoptene from Bulgarian rose oil. II. Saturated hydrocarbons other than eicosane. Dokl. Bulg. Akad. Nauk 7: 17-20 (1954).

[391] Jasper, J. J.; Kerr, E. R.; Gregorich, F. The orthobaric surface tensions and thermodynamic properties of the liquid surfaces of the n-alkanes, C(5) to C(28). J. Am. Chem. Soc. 75: 5252-5254 (1953).

[392] Kemula, W.; Buchowski, H.; Pawlowski, W. Effect of the position of substituents in an aromatic ring on $\mathrm{R}(\mathrm{f})$ and partition coefficients: II. Aromatic amines. Rocz. Chem. 42: 1951-1965 (1968).

[393] Klofutar, C.; Paljk, S.; Domanska, U. Heats of solution of 1-nonanol and 1-undecanol in n-hexane, n-heptane, n-decane and n-hexadecane at 298.15 K. Thermochim. Acta 158: 301 (1990).

[394] Krafft, F. A few higher normal paraffins. Chem. Ber. 19: 2218 (1886).

[395] Krafft, F. Nineteen higher normal paraffins $\mathrm{CnH} 2 \mathrm{n}+2$ and a simple volume law for the saturated liquid state. Ber. Dtsch. Chem. Ges. 15: 1711 (1882).

[396] Krafft, F. On nineteen higher normal paraffins and a simple volume law for liquids that form drops I. Ber. Dtsch. Chem. Ges. 15: 1687-1711 (1882).

[397] Lagerlof, D. Thermodynamic research: reduced formulas for simplified calculations of latent molar heat of evaporation. J. Prakt. Chem. 98: 136 (1918). 
[398] Lainez, A.; Rodrigo, M. M. Excess vol. and excess heat cap. of pyridine or piperidine + n-alkane(c7-c16). Int. DATA Ser.; Sel. Data Mixtures, Ser. A 2: 109-126 (1992).

[399] Lainez, A.; Rodrigo, M.-M.; Wilhelm, E.; Grolier, J.-P. E. Excess volumes and excess heat capacities of some mixtures with trans,trans,cis-1,5,9-cyclododecatriene at $298.15 \mathrm{~K}$. J. Chem. Eng. Data 34: 332-335 (1989).

[400] Lal, K.; Tripathi, N.; Dubey, G. P. Densities, viscosities, and refractive indices of binary liquid mixtures of hexane, decane, hexadecane, and squalane with benzene at $298.15 \mathrm{~K}$. J. Chem. Eng. Data 45: 961-964 (2000).

[401] Langedijk, S. L.; Smithuysen, W. C. B. The freezing point diagram of the system n-hexadecane + n-hexadecene-1 ( cetene). Recl. Trav. Chim. Pays-Bas 57: 1050 (1938).

[402] Larkin, J. A.; Fenby, D. V.; Gilman, T. S.; Scott, R. L. Heats of mixing of nonelectrolyte solutions, III. Solutions of the five hexane isomers with hexadecane. J. Phys. Chem. 70: (1966) 1959.

[403] Lee, C. H.; Dempsey, D. M.; Mohamed, R. S.; Holder, G. D. Vapor-liquid equilibria in the systems of n-decane/tetralin, n-hexadecane/ tetralin, n-decane/1-methylnaphthalene, and 1-methylnaphthalene/tetralin. J. Chem. Eng. Data 37: 183-186 (1992).

[404] Lenoir, J. M.; Hipkin, H. G. Enthalpies of mixtures of n-hexadecane and n-pentane. J. Chem. Eng. Data 15: 368-371 (1970).

[405] Levene, P. A. Org. Synth. 15: 27 (1935).

[406] Levene, P. A.; West, C. J.; Van der Scheer, J. J. Biol. Chem. 20: 521 (1915).

[407] Lim, C. B.; Williamson, A. G. Excess volumes of ternary and quaternary mixtures of n-alkanes. J. Chem. Thermodyn. 12: 65-70 (1980).

[408] Mabery, C. F. J. Soc. Chem. Ind. (London) 19: 502 (1900).

[409] Mabery, C. F. Am. Chem. J. 28: 174 (1902).

[410] Mansker, L. D.; Criser, A. C.; Jangkamolkulchai, A.; Luks, K. D. The isothermal compressibility of n-paraffin liquids at low pressures. Chem. Eng. Commun. 57: 87 (1987).

[411] Marsh, K. N.; Organ, P. P. Excess molar enthalpies and excess molar volumes for threeand four-component n-alkane mixtures simulating (n-hexane + n-hexadecane). J. Chem. Thermodyn. 17: 835-841 (1985).

[412] Matsui, M.; Arakawa, S. Mem. Coll. Sci.; Univ. Kyoto, Ser. A. 15: 189 (1932).

[413] Matthews, M. A.; Rodden, J. B.; Akgerman, A. High-temperature diffusion, viscosity and density measurements in n-hexadecane. J. Chem. Eng. Data 32: 317-319 (1987).

[414] McKinney, J. W. The constitution of kerogen. J. Am. Chem. Soc. 968-979 (1924).

[415] McMakin, L. E. J.; Van Winkle, M. Vapor-liquid equilibrium of n-hexadecane-bibenzyl-phenanthrene system at $100 \mathrm{~mm}$. of mercury absolute. J. Chem. Eng. Data 7: 9-12 (1962).

[416] Messow, U.; Doye, U.; Kuntzsch, S. Int. DATA Ser.; Sel. Data Mixtures, Ser. A 2: 156 (1980).

[417] Mills, P. L.; Fenton, R. L. Vapor pressures, liquid densities, liquid heat capacities, and ideal gas thermodynamic properties for 3-methylhexanal and 3,4-dimethylpentanal. J. Chem. Eng. Data 32: 266-273 (1987).

[418] Mogollon, E.; Kay, W. B.; Teja, A. S. Modified sealed-tube method for the determination of critical temperature. Ind. Eng. Chem. Fundamentals 21: 173-175 (1982).

[419] Mukhamedzyanov, G. K.; Usmanov, A. G.; Tarzimanov, A. A. determination of the thermal conductivity of liquid saturated hydrocarbons. Izvestiya Vysshikh Uchebnykh Zavedenii, Neft Gaz 6: 75-79 (1963). 
[420] Mumford, S. A.; Phillips, J.W.C. The physical properties of some aliphatic compounds. J. Chem. Soc. (London) 75-84 (1950).

[421] Mustafaev, R. A. Inzh.-Fiz. Zh. 24: 663-668 (1973).

[422] Myers, H. S. Volatility characteristics of high-boiling hydrocarbons. PhD, Pennsylvania State University, College Park, PA (1952).

[423] Myers, R. S.; Clever, H. L. Surface tension of octamethylcyclotetrasiloxane and hexamethyldisilazane and their solutions with carbon tetrachloride and n-hexadecane. J. Chem. Eng. Data 14: 161-164 (1969).

[424] Myers, H. S.; Fenske, M. R. Measurement and correlation of vapor pressures data for high boiling hydrocarbons. Ind. Eng. Chem. 47: 1652 (1955).

[425] Nederbragt, G. W.; Boelhouwer, J. W. M. Physica 305 (1947).

[426] Nhaesi, A. H.; Asfour, A. F. A. Densities and kinematic viscosities of ten regular liquid systems at 293.15 and 298.15 K. J. Chem. Eng. Data 45: 991-995 (2000).

[427] Oddo, G. Gazz. Chim. Ital. 31 (1901).

[428] Orwoll, R. A.; Flory, P. J. Equation-of-state parameters for normal alkanes. Correlation with chain length thermodynamic properties of binary mixtures of n-alkanes. J. Am. Chem. Soc. 89: 6814-6822 (1967).

[429] Parks, G. S.; Moore, G. E.; Renquist, M. L.; Naylor, B. F.; McClaine, L. A.; Fujii, P. S.; Hatton, J. A. Thermal data on organic compounds. XXV. Some heat capacity, entropy and free energy data for nine hydrocarbons of high molecular weight. J. Am. Chem. Soc. 71: 3386 (1949).

[430] Perez, P.; Valero, J.; Gracia, M.; Gutierrez Losa, C. G(E)(m) (298.15 K) of mixtures containing 1,2-dichloropropane or 1,3-dichloropropane. J. Chem. Thermdyn. 21: 259-264 (1989).

[431] Petrov, A. D.; Kaplan, E. P. Zhurnal Obshchei Khim 12: 99 (1942).

[432] Philippe, R.; Delmas, G. Int. DATA Ser.; Sel. Data Mixtures, Ser. A 1: 69 (1982).

[433] Pilcher, G. Anal. Chim. Acta 17: 144 (1957).

[434] Plebanski, T.; Wozniak, M.; Wilanowska, K. A dilatometric method for measuring the density of organic liquids at elevated temperatures. Nauchn. Appar. 1: 47-59 (1986).

[435] Powell, R. W.; Groot, H. Use of thermal comparator method for thermal conductivity measurements on liquids: values for three organic series: normal alcohols, acids and saturated hydrocarbons. Int. J. Heat and Mass Transfer 15: 360-366 (1972).

[436] Prophete, H. Contribution to the study of flowers. Wax from roses. C. R. Hebd. Seances Acad. Sci. 183 (1926).

[437] Queimada, A. J.; Quinones-Cisneros, S. E.; Marrucho, I. M.; Coutinho, J. A. P.; Stenby, E. $\mathrm{H}$. Viscosity and liquid density of asymmetric hydrocarbon mixtures. Int. J. Thermophys. 24: 1221-1239 (2003).

[438] Ralston, A. W.; Crews, L. T.; Hoerr, C. W. Solubilities of some normal saturated aliphatic hydrocarbons. J. Org. Chem. 9: 319-327 (1944).

[439] Rasskazov, D. S.; Babikov, Y. M.; Filatov, N. Y. Tr. Mosk. Energ. Inst. 179: 62 (1974).

[440] Rastorguev, Y. I.; Keramidi, A. S. Izvestiya Vysshikh Uchebnykh Zavedenii, Neft Gaz (1972) 15: 61.

[441] Ratkovics, F.; Salamon, T.; Domonkos, L. Magy. Kem. Foly. 80: 264 (1974).

[442] Richardson, J. W.; Parks, G. S. Thermal data on organic compounds XIX. Modern combustion data for some non-volatile compounds containing carbon, hydrogen and oxygen. J. Am. Chem. Soc. 61: 3543 (1939). 
[443] Rolo, L. I.; Caco, A. I.; Queimada, A. J.; Marrucho, I. M.; Coutinho, J. A. P. Surface tension of heptane, decane, hexadecane, eicosane, and some of their binary mixtures. J. Chem. Eng. Data 47: 1442-1445 (2002).

[444] Rosenthal, D. J.; Teja, A. S. The critical properties of n-alkanes using a low-residence time flow apparatus. AIChE J. 35: 1829 (1989).

[445] Sakiadis, B. C.; Coates, J. Studies of thermal conductivity of liquids, Part III. AIChE J. 3: 121-126 (1957).

[446] Sanin, P. I.; Melent'eva, N. V. Tr. Inst. Nefti. Akad. Nauk SSSR 13: 58 (1959).

[447] Seyer, W. F.; Patterson, R. F.; Keays, J. L. The density and transition points of the n-paraffin hydrocarbons. J. Am. Chem. Soc. 66: 179-182 (1944).

[448] Smith, J. C. J. Chem. Soc. 737 (1932).

[449] Smith, R. L.; Anselme, M.; Teja, A. S. World Congress III Chem. Eng., Tokyo, II, 135 (1986).

[450] Smith, R. L.; Teja, A. S.; Kay, W. B. Measurement of critical temperatures of thermally unstable n-alkanes. AIChE J. 33: 232 (1989).

[451] Snow, R. L.; Ott, J. B.; Goates, J. R.; Marsh, K. N.; O'Shea, S.; Stokes, R. H. (Solid + liquid) and (vapor + liquid) phase equilibria and excess enthalpies for (benzene + n-tetradecane), (benzene + n-hexadecane), (cyclohexane + n-tetradecane), and (cyclohexane + n-hexadecane) at 293.15, 298.15, and 308.15 K. Comparison of G(E)(m) calculated from (vapor + liquid) and (solid + liquid) equilibria. J. Chem. Thermodyn. 18: 107-130 (1986).

[452] Snyder, P. S.; Winnick, J. The pressure, volume and temperature properties of liquid n-alkanes at elevated pressures. Proc. Symp. Thermophys. Prop. 5: 115-129 (1970).

[453] Sondheimer, F.; Amiel, Y. Unsaturated macrocyclic compounds III. Synthesios of cyclohexadeca-1,3,9,11 -tetrayne by a novel cyclization reaction. J. Am. Chem. Soc. 79: 5817 (1957).

[454] Sorabji, K. B. B. J. Chem. Soc. 47: 37-41 (1885).

[455] Suehnel, K.; Geidel, E.; Kaden, R. Excess volumes of binary systems from ketones and n-alkanes. Z. Phys. Chem. (Leipzig) 267: 593 (1986).

[456] Tanaka, Y.; Hosokawa, H.; Kubota, H.; Makita, T. Viscosity and density of binary mixtures of cyclohexane with n-octane, n-dodecane, and n-hexadecane under high pressures. Int. J. Thermophysics 12: 245-264 (1991).

[457] Tardajos, G.; Pena, M. D.; Aicart, E. Speed of sound in pure liquids by a pulse-echo-overlap method. J. Chem. Thermodyn. 18: 683-689 (1986).

[458] Tardajos, G.; Aicart, E.; Costas, M.; Patterson, D. Liquid structure and second-order mixing functions for benzene, toluene and p-xylene with n-alkanes. J. Chem. Soc.; Faraday Trans. 1 82: 2977-2987 (1986).

[459] Tarzimanov, A. A.; Mashirov, V. E. Experimental investigation of the thermal conductivity of vapours of normal saturated hydrocarbons at temperatures up to $450 \mathrm{deg}$ C. Teploenergetika (Moscow) 14: 67 (1967).

[460] Teja, A. S.; Rice, P. Densities of benzene-n-alkane mixtures. J. Chem. Eng. Data 21: 173-175 (1976).

[461] Teja, A. S.; Gude, M.; Rosenthal, D. J. Novel methods for the measurement of the critical properties of thermally unstable fluids. Fluid Phase Equilib. 52: 193 (1989).

[462] Terhoff, W. Recovery of isooctane (2,2,4-trimethylpentane). Brauwissenschaft 28: 52 (1975). 
[463] Tilicheev, M. D.; Kachmarchik, Y. M. Neft. Khoz. 25: 45 (1947).

[464] Tilicheev, M. D.; Kachmarchik, Y. M. Basic physico-chemical constants of n-alkanes c(13)-c(19). Zhurnal Obshchei Khim 21: 78-85 (1951).

[465] Tilicheev, M. D.; Peshkov, V. P.; Yuganova, S. A. Cryoscopic constants and transition temperatures of normal alkanes. Zhurnal Obshchei Khim 21: 1229-1237 (1951).

[466] Trejo, L. M. Int. DATA Ser.; Sel. Data Mixtures, Ser. A 1: 14 (1991).

[467] Treszczanowicz, A. J.; Kiyohara, O.; Benson, G. C. Excess volumes for n-alkanols + n-alkanes. IV. Binary mixtures of decan-1-ol + n-pentane, + n-hexane, + n-octane, + n-decane, and + n-hexadecane. J. Chem. Thermodyn. 13: 253-260 (1981).

[468] Treszczanowicz, T.; Benson, G. C.; Lu, B. C. Y. Excess volumes for binary mixtures formed by 2,5,8,11- tetraoxadodecane or 2,5,8,11,14-pentaoxapentadecane with homologous n-alkanes. Thermochim. Acta 168: 95-102 (1990).

[469] Tuot, M.; Guyard, M. Bull. Soc. Chim. Fr. 1086-1096 (1947).

[470] Ubbelohde, A. R. Structure and thermodynamic properties of long-chain compounds. Trans. Farad. Soc. 34: 282 (1938).

[471] Van Hook, A.; Silver, L. Premelting anomalies of some long-chain normal paraffin hydrocarbons. J. Chem. Phys. 10: 686-690 (1942).

[472] Vavanellos, T. D.; Asfour, A.-F.; Siddique, M. H. Kinematic viscosity-composition data for eight binary systems containing toluene or ethylbenzene and c8-c16 n-alkanes at 308.15 and 313.15 K. J. Chem. Eng. Data 36: 281-284 (1991).

[473] Vogel, A. I. Physical properties and chemical constitution. Part IX. Aliphatic hydrocarbons. J. Chem. Soc. 1946: 133-139 (1946).

[474] Wada, Y.; Nagasaka, Y.; Nagashima, A. Measurements and correlation of the thermal conductivity of liquid n-paraffin hydrocarbons and their binary and ternary mixtures. Int. J. Thermophys. 6: 251-265 (1985).

[475] Wakefield, D. L. Viscosities of nonelectrolyte liquid mixtures. III. Selected binary and quaternary mixtures. Int. J. Thermophysics 1988; 9: 365-381.

[476] Wakefield, D. L.; Marsh, K. N. Viscosities of nonelectrolyte liquid mixtures. I. n-hexadecane + n-octane. Int. J. Thermophys. 8: 649-662 (1987).

[477] Wang, L.; Benson, G. C.; Lu, B. C.-Y. Excess volumes for binary mixtures of n-butyl methyl ether with n-alkanes at 298.15 K. J. Chem. Eng. Data 35: 242-244 (1990).

[478] Waterman, H. I.; Leendertse, J. J.; Van Krevelen, D. W. Preparation of some pure hydrocarbons for the purpose of testing physical methods in use for the examination of hydrocarbon mixtures. Rev. Pet. Technol. (London) 25 (1939).

[479] Whitmore, F. C.; Sommer, L. H.; DiGiorgio, P. A.; Strong, W. A.; Van Strein, R. E.; Bailey, D. L.; Hall, H. K.; Pietrusza, E. W.; Kerr, G. T. Organo-silicon compounds, i. synthesis and properties of n-alkyltrimethyl-and n-alkyltriethyl-silanes. J. Am. Chem. Soc. 68: 475-481 (1946).

[480] Wilhelm, E.; Lainez, A.; Roux, A. H.; Grolier, J.-P. E. Excess molar volumes and heat capacities of (1,2,4-trichlorobenzene + an $n$-alkane) and (1-chloronpahthalene + an n-alkane). Thermochim. Acta 105: 101 (1986).

[481] Wilhelm, E.; Inglese, A.; Roux, A. H.; Grolier, J.-P. E. Excess enthalpy, excess heat capacity and excess volume of 1,2,4-trimethylbenzene + , and 1-methylnaphthalene + an n-alkane. Fluid Phase Equilib. 34: 49-67 (1987).

[482] Witek, M.; Goldon, A.; Hofman, T.; Domanska, U. Densities and excess volumes of methyl 1,1-dimethylpropyl ether + benzene, or cyclohexane, or an alkane (C6-C16) at 
298.15 K. J. Chem. Eng. Data 42: 60-63 (1997).

[483] Wu, J.; Shan, Z.; Asfour, A. A. Viscometric properties of multicomponent liquid n-alkanes. Fluid Phase Equilib. 143: 263-274 (1998).

[484] Young, S. On the boiling points of the normal paraffins at different pressures; Proc. Roy. Irish Acad. 38B, 65-92 (1928).

[485] Zeinalov, B. K.; Leikakh, V. S. Izvestiya Akademii Nauk Az. SSR 10: 3 (1954).

[486] Ziegler, K.; Dersch, F.; Wollthan, H. Alkali organic compounds XI. Mechanism of polymerization of unsaturated hydrocarbons by alkali metal and alkali alkyls. Justus Liebigs Ann. Chem. 511: 13-44 (1934).

[487] Aicart, E.; Tardajos, G.; Diaz Pena, M. Isothermal compressibility of cyclohexane-n-decane, cyclohexane-n-dodecane, and cyclohexane-n-tetradecane. J. Chem. Eng. Data 26: 22-26 (1981).

[488] Allemand, N.; Jose, J.; Michou-Saucet, C. An instrument for the measurement of vapor pressure (range: 3-1000 Pa). Thermochim. Acta 98: 237-253 (1986).

[489] Allemand, N.; Jose, J.; Merlin, J. C. Measurement of the vapor pressure of hydrocarbons c10 to c18 n-alkanes and n-alkylbenzenes in the range 3-1000 Pascal. Thermochim. Acta 105: 79-90 (1986).

[490] Ambrose, D.; Townsend, R. Critical temperatures and pressures of some alkanes. Trans. Faraday Soc. 64: 2622-2631 (1968).

[491] Aminabhavi, T. M.; Banerjee, K. Thermodynamic interactions in binary mixtures of 1-chloronaphthalene with n-alkanes. Ind. J. Chem. 40A: 53-64 (2001).

[492] Aminabhavi, T. M.; Patil, V. B. Density, refractive index, viscosity, and speed of sound in binary mixtures of ethylbenzene with hexane, heptane, octane, nonane, decane, and dodecane. J. Chem. Eng. Data 42: 641-646 (1997).

[493] Aralaguppi, M. I.; Jadar, C. V.; Aminabhavi, T. M. Density, Refractive index, viscosity, and speed of sound in binary mixtures of cyclohexanone with hexane, heptane, octane, nonane, decane, dodecane, and 2,2,4-trimethylpentane. J. Chem. Eng. Data 44: 435-440 (1999).

[494] Aucejo, A.; Part, E.; Medina, P.; Sancho-Tello, M. Viscosity of some n-alkane/1-chloroalkane binary liquid mixtures. J. Chem. Eng. Data 31: 143-145 (1986).

[495] Aucejo, A.; Burguet, M. C.; Munoz, R.; Marques, J. L. Densities, viscosities, and refractive indices of some n-alkane binary liquid systems at 298.15 K. J. Chem. Eng. Data 40: 141-147 (1995).

[496] Aucejo, A.; Part, E.; Medina, P.; Sancho-Tello, M. Viscosity of some n-alkane/1-chloroalkane binary liquid mixtures. J. Chem. Eng. Data 31: 143-145 (1986).

[497] Awwad, A. M.; Allos, E.I. Thermodynamic properties of binary mixtures of isooctane and n-alkane at 298.15 K. Fluid Phase Equilib. 22: 353-365 (1985).

[498] Beale, E. S. L.; Docksey, P. A Wide Range Boiling-point conversion chart for hydrocarbons and petroleum products. J. Inst. Petrol. Tech. 21: 860-870 (1935).

[499] Benson, G. C.; Kumaran, M. K.; Treszczanowicz, A. J.; D'Arcy, P. J.; Halpin, C. J. Thermodynamic properties for 2,5,8,11-tetraoxadodecane + n-dodecane mixtures at 298.15 K. Thermochim. Acta 95: 59 (1985).

[500] Bessieres, D.; Saint-Guirons, H.; Daridon, J.-L. High pressure measurement of n-doceane heat capacity up to $100 \mathrm{MPa}$. Calculation from equations of state. High Pressure Research 18: 279-284 (2000).

[501] Bidlack, D. L.; Anderson, D. K. Mutual diffusion in nonideal, nonassociating liquid 
systems. J. Phys. Chem. 68: 3790-3794 (1964).

[502] Bingham, E. C.; Fornwalt, H. J. Chemical constitution and association. J. Rheol. 1: 372-417 (1930).

[503] Burgdorf, R.; Zocholl, A.; Arlt, W.; Knapp, H. Thermophysical properties of binary liquid mixtures of polyether and n-alkane at 298.15 and $323.15 \mathrm{~K}$ : Heat of mixing, heat capacity, viscosity, density and thermal conductivity. Fluid Phase Equilib. 164: 225-255 (1999).

[504] Campbell, T. W.; Burney, W.; Jacobs, T. L. The reaction of Gignard reagents with d-t-butyl peroxide. J. Am. Chem. Soc. 72: 2735 (1950).

[505] Caudwell, D. R.; Trusler, J. P. M.; Vesovic, V.; Wakeham, W. A. The viscosity and density of n-dodecane and n-octadecane at pressures up to $473 \mathrm{~K}$. 15th Intl. Symp. on Thermophysical Properties, Boulder, CO (2003).

[506] Celda, B.; Gavara, R.; Tejero, R.; Figueruelo, J. E. Dynamic viscosities of n-alkanes and 2-butanone mixtures at 20 deg. C. J. Chem. Eng. Data 32: 31-33 (1987).

[507] Crawford, W.; Harbourn, C. L. A. Anal. Chem. 27: 1449 (1955).

[508] Cutler, W. G. A study of the compressions of several high molecular weight hydrocarbons. Ph.D.; Pennsylvania State University, University Park, PA (1955).

[509] Cutler, W. G.; McMickle, R.H.; Webb, W.; Schiessler, R.W. Study of the compressions of several high molecular weight hydrocarbons. J. Chem. Phys. 29: 727-740 (1958).

[510] Dejoz, A.; Gonzalez-Alfaro, V.; Miguel, P. J.; Vazquez, M. I. Isobaric vapor-liquid equilibria for binary systems composed of octane, decane and dodecane at $20 \mathrm{kPa}$. J. Chem. Eng. Data 41: 93-96 (1996).

[511] Dornte, R. W.; Smyth, C. P. The dielectric polarization of liquids. X. The polarization and refraction of the normal paraffins. J. Am. Chem. Soc. 52: 3546-3552 (1930).

[512] Drabek, O.; Cibulka, I. Excess molar volumes of binary mixtures of acetic acid and propionic acid with some members of homologous series of alkanes. Collection Czechoslov, Chem. Commun. 56: 736-744 (1991).

[513] Dymond, J. H.; Robertson, J.; Isdale, J. D. Transport properties of nonelectrolyte liquid mixtures. III. Viscosity coefficients for n-octane, n-dodecane, and equimolar mixtures of $\mathrm{n}$-octane $+\mathrm{n}$-dodecane from 25 to $100 \mathrm{C}$ at pressures up to the freezing pressure of 500 MPa. Int. J. Thermophys. 2: 133-154 (1981).

[514] Dymond, J. H.; Robertson, J.; Isdale, J. D. (p, Rho, T) of some pure n-alkanes and binary mixtures of n-alkanes in the range 298 to $373 \mathrm{~K}$ and 0.1 to $500 \mathrm{MPa}$. J. Chem. Thermodyn. 14: 51-59 (1982).

[515] Dymond, J. H.; Glen, N. F.; Isdale, J. D. Transport properties of nonelectrolyte liquid mixtures - VII. Viscosity coefficients for isooctane and for equimolar mixtures of isooctane $+\mathrm{n}$-octane and isooctane $+\mathrm{n}$-dodecane from 25 to $100{ }^{\circ} \mathrm{C}$ at pressures up to 500 $\mathrm{MPa}$ or to the freezing pressure. Int. J. Thermophys. 6: 233-250 (1985).

[516] Francis, A. W. Pressure-temperature-liquid density relations of pure hydrocarbons. Ind. Eng. Chem. 1779-1786 (1957).

[517] Garcia, B.; Alcalde, R.; Aparicio, S.; Leal, J. M. Thermophysical behavior of methylbenzoate $+n$-alkanes mixed solvents. application of cubic equations of state and viscosity models. Ind. Eng. Chem. Res. 41: 4399-4408 (2002).

[518] Gensler, W. J.; Mahadevan, A. P.; Casella, J. Preparation and constitution of nonadiyne-1,4. J. Am. Chem. Soc. 78: 163 (1956).

[519] Gierycz, P.; Rogalski, M.; Malanowski, S. Vapour-liquid equilibria in binary systems formed by n-methylpyrrolidone with hydrocarbons and hydroxyl derivatives. Fluid Phase 
Equilib. 22: 107-122 (1985).

[520] Giller, E. B.; Drickamer, H. G. Viscosity of normal paraffins near the freezing point. Ind. Eng. Chem. 41: 2067-2069 (1949).

[521] Gomez-Ibanez, J.; Liu, C.-T. The excess volume of mixtures of cyclohexane and some normal alkanes. J. Phys. Chem. 65: 2148-2151 (1961).

[522] Gonzalez, B.; Dominguez, A.; Tojo, J. Viscosities, densities and speeds of sound of the binary systems: 2-propanol with octane, or decane, or dodecane at $\mathrm{T}=(293.15,298.15$, and 303.15)K. J. Chem. Thermodyn. 35: 939-953 (2003).

[523] Gouel, P. Density of alkanes (C6 to C16) cyclics and alkyl-benzenes. Bull. Cent. Rech. Explor.-Prod. Elf-Aquitaine 2: 211-225 (1978).

[524] Grigg, R. B.; Goates, J. R.; Ott, J. B. Excess volumes and excess enthalpies for (n-dodecane + n-octane) and excess volumes for (n-dodecane + cyclohexane) at $298.15 \mathrm{~K}$. J. Chem. Thermodyn. 14: 101-102 (1982).

[525] Grolier, J.-P.; Benson, G. C. Thermodynamic properties of binary mixtures containing ketones. VIII. Heat capacities and volumes of some n-alkanone + n-alkane mixtures at 298.15 K. Can. J. Chem. 62: 949-953 (1984).

[526] Guieu, R.; Faradjzadeh, A.; Carbonnel, L. Int. DATA Ser.; Sel. Data Mixtures, Ser. A 1: 50 (1980).

[527] Hamam, S. E. M.; Kumaran, M. K.; Zhang, D.; Benson, G. C. Excess enthalpies of binary mixtures of 2,4-dimethylpentane with n-hexane, n-heptane, n-octane, and n-dodecane. J. Chem. Eng. Data 30: 222-224 (1985).

[528] Hansen, R. S.; Hansen, R. D. J. Phys. Chem. 59: 496 (1955).

[529] Hogenboom, D. L.; Webb, W.; Dixon, J. A. Viscosity of several liquid hydrocarbons as a function of temperature, pressure, and free volume. J. Chem. Phys. 46: 2586-2598 (1967).

[530] Horie, H.; Morikawa, K. Research on compostion of fushun shale oil. XIV. Properties and paraffin hydrocarbons of the cuts distilling at 200-240 deg. Kogyo Kagaku Zasshi 41: 401-403 (1938).

[531] Houser, H. F.; McLean, A. M. Vapor-liquid equilibria of naphthalene-n-dodecane, n-dodecane-butyl carbitol, and naphthalene-butyl carbitol systems at subatmospheric press. Chem. Eng. Data Series 2: 12-16 (1957).

[532] Iwahashi, M.; Yamaguchi, Y.; Ogura, Y.; Suzuki, M. Dynamical structures of normal alkanes, alcohols, and fatty acids in the liquid state as determined by viscosity, self-diffusion coefficient, infrared spectra, and 13CNMR spin-lattice relaxation time measurements. Bull. Chem. Soc. Japan 63: 2154-2158 (1990).

[533] Jessup, R. S.; Stanley, C. L. Heats and volumes of mixing in several c12 hydrocarbon systems. J. Chem. Eng. Data 6: 368-371 (1961).

[534] Jobst, W. Measurement of thermal conductivitites of organic aliphatic liquids by an absolute unsteady-state method. Int. J. Heat Mass Transfer 7: 725-732 (1964).

[535] Kashiwagi, H.; Makita, T. Viscosity of twelve hydrocarbon liquids in the temperature range 298-348 $\mathrm{K}$ at pressures up to $110 \mathrm{MPa}$. Int. J. Thermophysics 3: 289-305 (1982).

[536] Kashiwagi, H.; Oishi, M.; Tanaka, Y.; Kubota, H.; Makita, T. Thermal conductivity of fourteen liquids in the temperature range 298-373 K. Int. J. Thermophys. 3: 101-116 (1982).

[537] Keistler, J. R.; Andrews, L. J. Vapor-liquid equlibria at subatmospheric pressures. hexadecene. Ind. Eng. Chem. 44: 622-624 (1952).

[538] Keramidi, A. S.; Rastorguev, Ya. L. Viscosity of n-dodecane. Izvestiya Vysshikh 
Uchebnykh Zavedenii, Neft Gaz 13: 113-114 (1970).

[539] Kharasch, M. S.; Holton, P. G.; Nudenberg, W. J. Org. Chem. 19: 1600 (1954).

[540] Kincannon, C. B.; Manning, E. Purification of normal paraffins. Ind. Eng. Chem. 47: 149 (1955).

[541] Knapstad, B.; Skjolsvik, P. A.; Oye, H. A. Viscosity of pure hydrocarbons. J. Chem. Eng. Data 34: 37-43 (1989).

[542] Knapstad, B.; Skjolsvik, P. A.; Oye, H. A. Viscosity of three binary hydrocarbon mixtures. J. Chem. Eng. Data 36: 84-88 (1991).

[543] Kurtyka, Z. M.; Kurtyka, E. A. Vapor-liquid equilibria in the systems aniline-pseudocumene, o-toluidine-n-decane, and m-xylidine-n-dodecane at atmos. press. J. Chem. Eng. Data 24: 15 (1979).

[544] Landau, R.; Wuerflinger, A. PVT data of acetonitrile, undecane and dodecane to $3 \mathrm{kbar}$ and $-50 \mathrm{C}$ pressure dependence and change of volume, enthalpy and entropy. Ber. Bunsenges. Phys. Chem. 84: 895-902 (1980).

[545] Leslie, R. T.; Heuer, W. W. Study of the crystal behavior of hydrocarbons. Nat. Bur. Stand. (U.S.) J. Res. 18: 639 (1937).

[546] Lyvers, H. I.; Belyanina, E. T. Vapor-liquid equilibria of the naphthalene-n-dodecane and naphthalene -dipropylene glycol systems at $100 \mathrm{Mm}$ of mercury. J. Chem. Eng. Data 3: 60 (1958).

[547] Mair, B. J. The synthesis, purification, and certain physical constants of the normal hydrocarbons from pentane to dodecane, of $\mathrm{n}$-amyl bromide and of $\mathrm{n}$-nonyl bromide. Nat. Bur. Stand. (U.S.) J. Res. 9: 457 (1932).

[548] Mallan, G. M.; Michaelian, M. S.; Lockhart, F. J. Liquid thermal conductivities of organic compounds and petroleum fractions. J. Chem. Eng. Data 17: 412-414 (1972).

[549] Mears, T. W.; Stanley, C. L.; Compere, E. L.; Howard, F. L. Synthesis, purification, and physical properties of seven twelve-carbon hyd rocarbons. Nat. Bur. Stand. (U.S.) J. Res. 67: 475 (1963).

[550] Moreiras, A. F.; Garcia, J.; Lugo, L.; Comunas, M. J. P.; Lopez, E. R.; Fernandez, J. Experimental densities and dynamic viscosities of organic carbonate $+n$-alkane or p-xylene systems at 298.15 K. Fluid Phase Equilib. 204: 233-243 (2003).

[551] Morse, B. K. J. Am. Chem. Soc. 1957; 79: 3375.

[552] Mukhamedzyanov, I. K.; Mukhamedzyanov, G. Kh.; Usamov, A.G. Thermal conductivity of liquid saturated hydrocarbons from 1 to 2250 bar (in Russian). Trudy Kazanskogo Khimoco Tekhnol. Inst. 47: 22-28 (1971).

[553] Mustafaev, R. A. Thermal conductivity of the vapors of normal saturated hydrocarbons at high temperatures. Izvestiya Vysshikh Uchebnykh Zavedenii, Neft Gaz 16: $71-74$ (1973).

[554] Nayak, J. N.; Aralaguppi, M. I.; Aminanbhavi, T. M. Density, viscosity, refractive index, and speed of sound for the binary mixtures of ethyl chloroacetate with n-alkanes (C6 to C12) at (298.15, 303.15, and 308.15) K. J. Chem. Eng. Data 46: 891-896 (2001).

[555] Neruchev, Y. A.; Zotov, V. V.; Otpushchennikov, N. F. Velocity of sound in the homologous series of n-alkanes. Russ. J. Phys. Chem. 43: 1597-1599 (1969).

[556] Ortega, J.; Paz-Andrade, M. I.; Rodriguez-Nunez, E.; Jimenez, E. Excess molar volumes of binary mixtures of 2-hexanone with n-alkane at $298.15 \mathrm{~K}$. Can. J. Chem. 63: 3354-3356 (1985).

[557] Ortega, J.; Paz-Andrade, M. I.; Rodriguez, E. Excess molar volumes of the mixtures hexan-2-ol + n-alkane at 298.15 K. J. Chem. Eng. Data 31: 336-338 (1986). 
[558] Ortega, J.; Matos, J. S.; Pena, J. A.; Paz Andrade, M. I.; Pias, L.; Fernandez, J. Isobaric expansivities of the binary mixtures $\mathrm{C} 3 \mathrm{H} 7(\mathrm{OH})+\mathrm{CnH} 2 \mathrm{n}+2(\mathrm{n}=11,12)$ between 288.15 and 318.15 K. Thermochim. Acta 131: 57 (1988).

[559] Ott, J. B.; Goates, J. R. (Solid + liquid) phase equilibria in binary mixtures containing benzene, a cycloalkane, an n-alkane, or tetrachloromethane. An equation for representing (solid + liquid) phase equilibria. J. Chem. Thermodyn. 15: 267-278 (1983).

[560] Pak, S. C.; Kay, W. B. The critical properties of binary hydrocarbon systems. Ind. Eng. Chem. Fundam. 11: 255-267 (1972).

[561] Quayle, O. R.; Day, R. A.; Brown, G. M. A study of organic parachors. VII. A series of saturated hydrocarbons. J. Am. Chem. Soc. 66: 938-941 (1944).

[562] Sahgal, A.; Hayduk, W. Ethylene solubility and diffusivity in hexane-dodecane and ethylene glycol-butanol solutions. J. Chem. Eng. Data 24: 222-227 (1979).

[563] Schmidt, R. L.; Randall, J. C.; Clever, H. L. The surface tension and density of binary hydrocarbon mixtures: benzene-n-hexane and benzene-n-dodecane. J. Phys. Chem. 70: 3912-3916 (1966).

[564] Seyer, W. F. Mutual solubilities of hydrocarbons, II. The freezing point curves of dotricontane (dicetyl) in dodecane, decane, octane, hexane, cyclohexane and benzene. J. Am. Chem. Soc. 60: 827-830 (1938).

[565] Shen, S.; Wang, Y.; Feng, H.; Shi, J. Measurement of excess enthalpies for alkane-ketone systems. Nanjing Huagong Xueyuan Xuebao 13: 50-52 (1991).

[566] Shepard, A. F.; Henne, A.L.; Midgley, T. Physical properties of the normal paraffin hydrocarbons, pentane to dodecane. J. Am. Chem. Soc. 53: 1948-1958 (1931).

[567] Smith, J. F. D. The thermal conductivity of liquids. Trans. ASME 58: 719-725 (1936).

[568] Sondheimer, F.; Amiel, Y.; Wolovsky, R. Unsaturated macrocyclic compounds iv. the oxidation of terminal diacetylenes to macrocyclic tetraacetaylenes. J. Am. Chem. Soc. 79: 6263 (1957).

[569] Suri, S. K. Thermodynamic properties of solutions containing an aliphatic amine. 2. excess volumes of binary mixtures of triethylamine with 12 hydrocarbons at $313.15 \mathrm{~K}$. J. Chem. Eng. Data 25: 390-393 (1980).

[570] Takagi, T.; Teranishi, H. Ultrasonic speeds and thermodynamics for binary solutions of n-alkanes under high pressures. Fluid Phase Equilib. 20: 315-320 (1985).

[571] Tanaka, Y.; Itani, Y.; Kubota, H.; Makita, T. Thermal conductivity of five normal alkanes in the temperature range $283-373 \mathrm{~K}$ at pressures up to $250 \mathrm{MPa}$. Int. J. Thermophysics 9: 331-350 (1988).

[572] Timmermans, J. Researches in stoichiometry. I. The heat of fusion of organic compounds. Bull. Soc. Chim. Belg. 44: 17-40 (1935).

[573] Trenzado, J. L.; Matos, J. S.; Segade, L.; Carballo, E. Densities, viscosities, and related properties of some (methyl ester + alkane) binary mixtures in the temperature range from 283.15 to 313.15 K. J. Chem. Eng. Data 46: 974-983 (2001).

[574] Treszczanowicz, T.; Lu, B. C.-Y. Isothermal vapour-liquid equilibria for 11 examples of (an ether + a hydrocarbon). J. Chem. Thermodyn. 18: 213-220 (1986).

[575] Treszczanowicz, T.; Benson, G. C.; Lu, B. C.-Y. Excess enthalpies for binary mixtures of 2, 5,8-trioxanonane or 2,5,8,11,14-pentaoxapentadecane with n-alkanes at $298.15 \mathrm{~K}$. J. Chem. Eng. Data 33: 379-381 (1988).

[576] Tsimering, L.; Kertes, A. S. Excess enthalpies of tri-n-butylphosphate + hydrocarbons. J. Chem. Thermodyn. 6: 411-415 (1974). 
[577] Vogel, L.; Schuberth, H. Some thermodynamic and fluid-dynamic data of the system n-hexane/n-dodecane. Wissenschaftliche Zeitschrift der Martin-Luther-Univ. Halle-Wittenberg, Math.--Naturwiss. Reihe 38: 153-156 (1989).

[578] Wang, L.; Benson, G. C.; Lu, B. C.-Y. Excess enthalpies for (di-n-propyl ether + n-alkane) at 298.15 K. J. Chem. Thermodyn. 20: 975-979 (1988).

[579] Weissler, A.; Del Grosso, V. A. Ultrasonic investigation of liquids. VI. Acetylene derivatives. J. Am. Chem. Soc. 72: 4209-4210 (1950).

[580] Yanes, C.; Maestre, A.; Perez-Tejeda, P.; Calvente, J. J. Excess molar volumes and refractive indices of Cis-9-octadecenoic acid + n-alkanes or alkan-1-Ols at $298.15 \mathrm{~K}$. J. Chem. Eng. Data 38: 512-515 (1993).

[581] Zook, H. D.; Goldey, R. N. Coupling of lithium alkyls and alkyl halides. Metal-halogen exchange reactions. J. Am. Chem. Soc. 75: 3975 (1953). 


\section{Appendix A. Discussion of Chemical Characterization}

\section{A.1. Procedures}

A sample of RP-1 kerosene-based rocket propellant was presented for analysis. The sample was drawn with a disposable pipette from a 5-gallon steel pail supplied by the Air Force Research Lab (designated P000016660). The liquid sample had a pale-red cast provided by a dying agent, and appeared to have the viscosity of a typical kerosene. The liquid had the characteristic kerosene odor.

The sample was analyzed with a gas chromatography/mass spectrometry method. A $30 \mathrm{~m}$ capillary column with a $0.1 \mu \mathrm{m}$ coating of $5 \%$ phenyl polydimethyl siloxane was chosen as the stationary phase. This phase provides separations based upon boiling temperature and also the polarity of the solute. In this context, polarity also includes points of unsaturation or aromaticity on the solute molecule. The sample was injected via a syringe into a split/splitless injector set with a 100 to 1 split ratio. The injector was operated at $350^{\circ} \mathrm{C}$ and a constant head pressure of $69 \mathrm{kPa}(10$ psig). The sample residence time in the injector was very short, thus the effect of sample exposure to this high temperature is expected to be minimal. The column was temperature programmed to provide complete and rapid elution with minimal loss of peak shape. Initially, the temperature was maintained isothermally at $60{ }^{\circ} \mathrm{C}$ for $2 \mathrm{~min}$, followed by a $2{ }^{\circ} \mathrm{C} / \mathrm{min}$ ramp to $90{ }^{\circ} \mathrm{C}$, followed by a $10{ }^{\circ} \mathrm{C} / \mathrm{min}$ ramp to $250{ }^{\circ} \mathrm{C}$. Although the analysis was allowed to run for $40 \mathrm{~min}$, all peaks were eluted after approximately $27 \mathrm{~min}$. Mass spectra were collected for each peak from 15 to 550 RMM (relative molecular mass) units. The areas under each peak were integrated with a commercial algorithm optimized to identify peaks that were at least an order of magnitude larger than the noise level. 


\section{A.2. Results}

Approximately 250 peaks can be discerned on the total ion chromatogram. Not all of these were chosen for integration, however. The integration protocol mentioned above selected only 70 peaks as exceeding the threshold peak width and intensity established for recognition. Of these, a subset was chosen for examination. These were divided into four groups:

First tier: Peaks representing $2 \%$ (mass/mass) or higher

Second tier: Peaks representing $1 \%$ or higher

Lights: Peaks that elute very early

Heavies: Peaks that elute very late

A few comments about the above categories are in order. First, the mass percents referred to are based on the assumption that all peaks have identical response factors. Thus, the mass percents obtained from the total ion chromatogram were recorded without calibration. To apply a calibration to the mass, one would have to make standard mixtures of each of the components of RP-1. Since we do not have all of the pure components to make up calibration mixtures, or the time and resources to do so, the only practical alternative was the assumption of equal response. What is the consequence of this assumption?

In general, the total ion current, and therefore the intensity of the peaks on a total ion chromatogram, depends upon the number and intensity of the fragments produced by the constituents. A greater ion current will be produced by species that produce more fragments. Thus larger heavier species that produce a richer fragmentation pattern will tend to be over-represented in intensity on the total ion chromatogram. On the other hand, smaller, lighter species, which will produce a less rich fragmentation pattern, will be more efficiently carried into the source. The larger heavier ones will be more likely to adsorb on surfaces along the way, despite efforts to 
prevent that. These two effects will cancel to some extent. In the case of RP-1, even the smaller molecules are reasonably rich in fragments. Therefore, the assumption of equal response factor is unlikely to be a major source of uncertainty.

The terms heavy and light need some explanation. In this context, they refer only to the time that is required for the components producing the peaks to emerge from the column. Note however that the column is not a pure boiling point column. Thus, the last component out is not necessarily the heaviest in terms of RMM. Unsaturation will play a role in this as well. Thus, if components of lighter RMM emerge after components of heavier RMM, this is not a concern. Rather, this is expected.

The constituents in the heavy category were not integrated for mass percent. This is because as the chromatogram proceeds, the peaks broaden and are less amenable to integration. Thus, to integrate these peaks, one needs a protocol different from that used with the earlier peaks. While this could have been done, there was no reason to do so for the purpose of this study.

The components that have been identified represent $70 \%$ of the total constituents of the RP-1 sample. Note that the dye is not among those materials identified.

\section{A.3. Identification of Components}

The ability to view the mass spectrum of each peak provides a great deal of insight into the identity of the constituent that produced it. It must be understood that it is not necessarily unequivocal, however. Not all peaks on a mass spectrum are created equally. Some are very instructive, some are ubiquitous, and some are distractions. The automated search routines that are available seek to match mass spectra with library file spectra. In all of these routines, match quality is determined by the intensity of a peak and also the m/e, or RMM value, of the fragment that the

peak represents. Once a database routine finds a "match," it provides a quality factor based upon 
the match up of these two parameters: intensity and m/e. A higher quality factor results from the match of a heavier and more intense m/e peak. An unfortunate consequence of the procedure is that very often, the highest quality factor matches are nonsense, and that the slate of matches that is produced is of matches unrelated chemically. For this reason, it is very rare for one to be able to have "the computer" find the matches for you. Rather, each mass spectrum will have to be interpreted individually, by hand.

It is critical to correctly identify the parent ion packet on the mass spectrum, and make sure that the computer has done so properly. If the computer has failed to do so, it is time to ignore the computer and to start analyzing the mass spectrum. In $80 \%$ of the spectra analyzed here, the software failed to properly identify the parent ion packet. In the tables shown in the text of this report, the quality factor is normalized to 100 and is referred to as the correlation coefficient. Sometimes a high number is obtained for this, sometimes not. Occasionally, the software will "identify" a compound and assign it a correlation coefficient of 90 (very high). Then, upon looking at the spectrum, it is apparent that the match is $200 \mathrm{~m} / \mathrm{e}$ units heavier than the compound being matched. The parent ion packed was misidentified by the computer, leading the operator "down the garden path." It is always possible to calculate the correlation coefficient, however, even if it is meaningless. In these instances, one must scroll through the spectrum until the correct pattern is recognized. Thus, even when a relatively low quality factor is obtained, the identification may be very certain. It becomes a matter of ignoring the m/e peaks that the computer weighted too heavily.

In the tables of results, the correlation coefficient is given, as well as a confidence indication. These range from U,S (uncertain and/or speculative) to $\mathrm{M}$ (confident) to $\mathrm{H}$ (highly confident). The purpose of the foregoing discussion on mass spectral interpretation, while by no means complete, was to give proper context for interpretation of the correlation coefficient and 
confidence columns in the tables of results.

In all cases, the chromatographic peaks were examined for mass spectral purity. What is meant by this is that each peak was examined to determine whether the beginning, centroid, and end of the peak represented the mass spectrum of the same compound. When two peaks closely elute, there is inevitably some chemical impurity of the overlapping tails of the peak. Examining the peak for mass spectral purity ensures that the most reliable region will be chosen for the identification.

The peaks are listed in the tables by retention time on the total ion chromatogram. This is determined at the peak apex. Usually, well shaped Gaussian-like peaks were obtained, consistent with high efficiency and high selectivity. Nearly all resolved peaks were resolved to baseline. In some cases, the mass spectra were determined from the spectrum taken at the peak apex, while in other cases, an average over just part or all of the chromatographic peak was used. This is denoted in the profile column in each table as a $\mathrm{S}$ (ingle) or $\mathrm{A}$ (verage). We conclude that the RP-1 sample used in this work is unusual because it has a surprising number of unsaturated compounds present.

\section{A.4. Thermal Decomposition}

The global decomposition kinetics of RP-1 was investigated at elevated temperatures and a function of time. From these experiments, a global pseudo-first-order rate constant was derived that describes the overall decomposition of the RP-1 sample. Those results are presented in Table 7.

\section{Bibliography for Chemical Characterization}

Bruno, T. J.; Svoronos, P. D. N. CRC handbook of basic tables for chemical analysis, CRC Press: Boca Raton, 1989.

Bruno, T. J.; Svoronos, P. D. N. CRC handbook of basic tables for chemical analysis, $2^{\text {nd }}$. ed., CRC Press: Boca Raton, 2004.

Andersen, P. C.; Bruno, T. J. Thermal decomposition kinetics of RP-1 rocket propellant. Ind. Eng. Chem. Res. 44: 1670-1676 (2005). 


\section{Appendix B. Computational Characterization of Surrogate Mixture Compounds}

The following four steps were taken to computationally characterize the compounds that were selected for the surrogate fuel mixture:

(a) Obtain equilibrium geometries from ab initio molecular orbital calculations. Use Hartree-Fock approximation as theory level with $6-31 \mathrm{G}^{*}$ basis sets (low level approximation, sufficient for visualization purposes).

(b) Calculate isosurfaces for two electron density values:

- Isosurface of electron density $0.002 \mathrm{e}-/ \mathrm{au} 3$ contains approx. $98 \%$ of a molecule. Rendered as a mesh;

- Isosurface of electron density 0.08 e-/au3 rendered as a solid surface to illustrate the core of the molecule;

- $1 \mathrm{au}$ (atomic unit) $=5.292 \mathrm{~nm}$.

(c) Color-map the electrostatic potential onto the electron density isosurfaces. The electrostatic potential is defined as the energy of interaction of a point positive charge with the nuclei and electrons of a molecule. The color-mapping indicates electron-rich regions in red and electron-poor regions in blue.

(d) Combining this information leads to molecular representations that comprise four dimensions:

- three dimensions conveying structure, and;

- one dimension conveying intramolecular charge distribution as a function of location.

The still images illustrated below were created with PC Spartan for Windows, version '02.*

\section{Bibliography for Computational Characterization}

Shusterman, G. P.; Shusterman, A. J. Teaching chemistry with electron density models. J. Chem. Educ. 74: 771-776 (1997).

Gillespie, R. J. Electron densities, atomic charges, and ionic, covalent, and polar bonds. J. Chem. Educ. 78: 1688-1690 (2001).

Gillespie, R. J.; Popelier, P. L. A. Chemical bonding and molecular geometry: from Lewis to electron densities, Oxford University Press: New York, 2001.

*Certain commercial entities, equipment, or materials may be identified in this document in order to describe an experimental procedure or concept adequately. Such identification is not intended to imply recommendation or endorsement by the National Institute of Standards and Technology, nor is it intended to imply that the entities, materials, or equipment are necessarily the best available for the purpose. 


\section{2,2-Dimethylbutane}

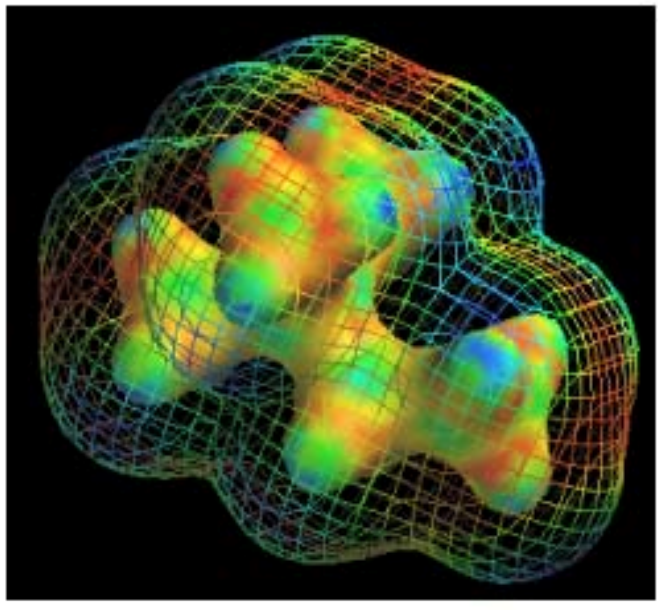

$$
\mathrm{C}_{6} \mathrm{H}_{14}
$$

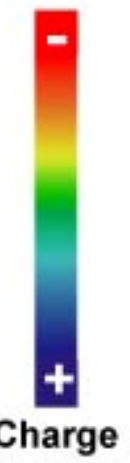

\begin{tabular}{|r|c|}
\hline Surface Area of Molecule / $A^{2}$ & 146.66 \\
\hline Volume of Molecule / $A^{3}$ & 123.59 \\
\hline Dipol moment/d & 0.04 \\
\hline
\end{tabular}

Figure 11. Molecular representation of 2,2-dimethylbutane.

\section{3-Ethyl-4,4-dimethyl-2-pentene}

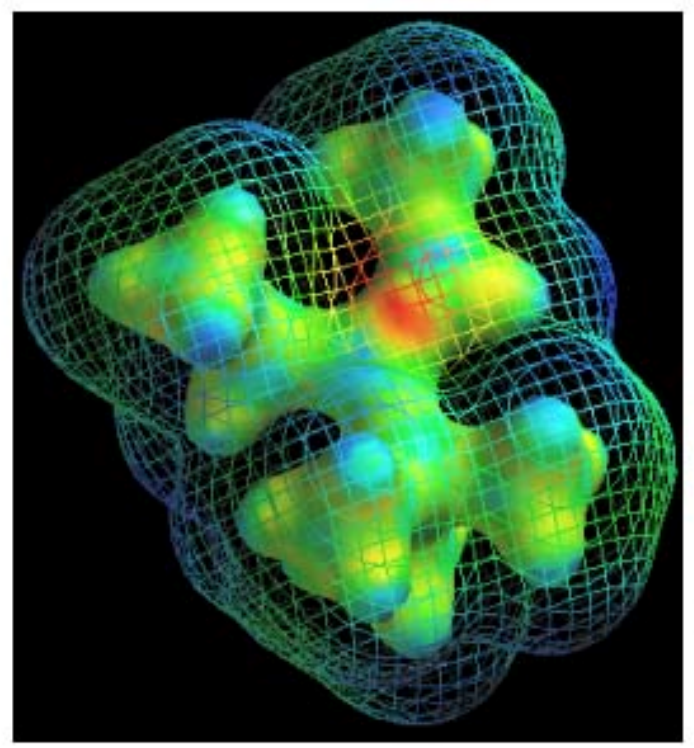

$$
\mathrm{C}_{9} \mathrm{H}_{18}
$$

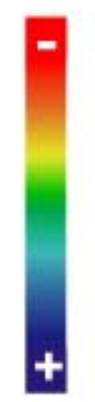

\section{Charge \\ Distribution}

\begin{tabular}{|r|c|}
\hline Surface Area of Molecule / $\mathrm{A}^{2}$ & 191.18 \\
\hline Volume of Molecule/A & 173.28 \\
\hline Dipol moment/d & 0.11 \\
\hline
\end{tabular}

Figure 12. Molecular representation of 3-ethyl-4,4-dimethyl-2-pentene. 


\section{Cyclodecene}
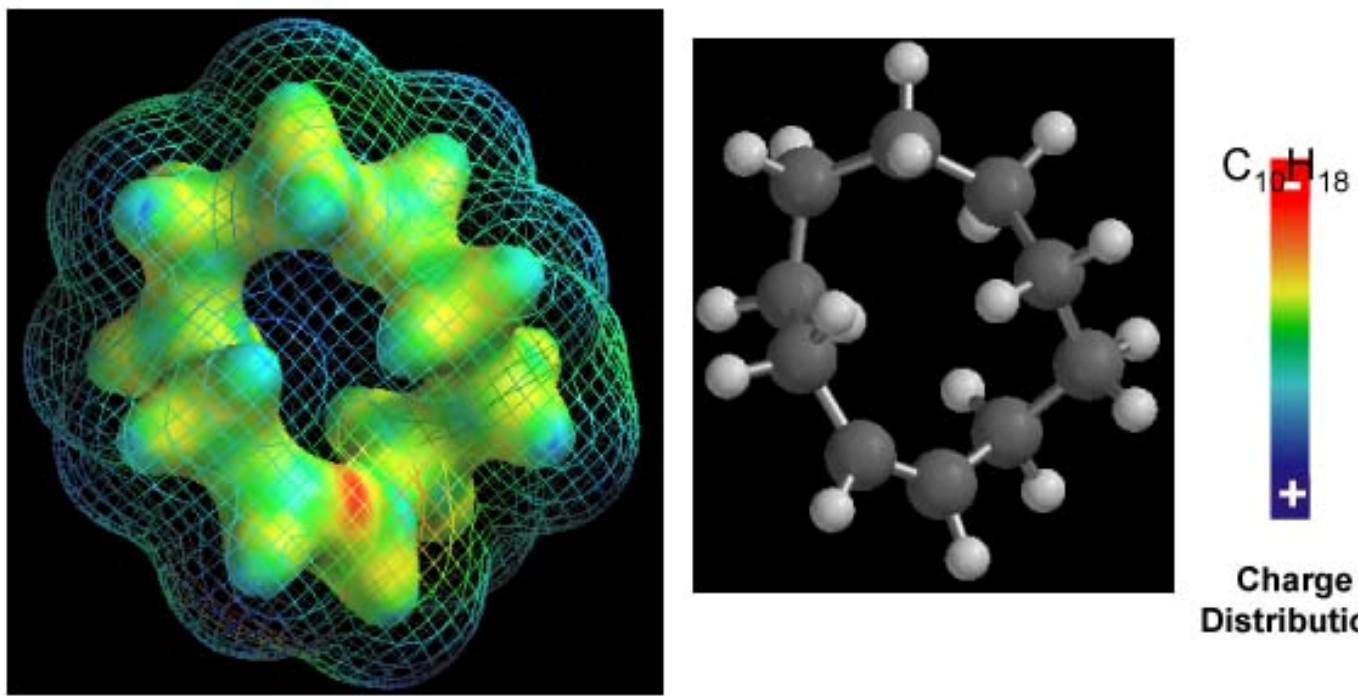

Charge

Distribution

Figure 13. Molecular representation of cyclodecene.

Cis-decaline
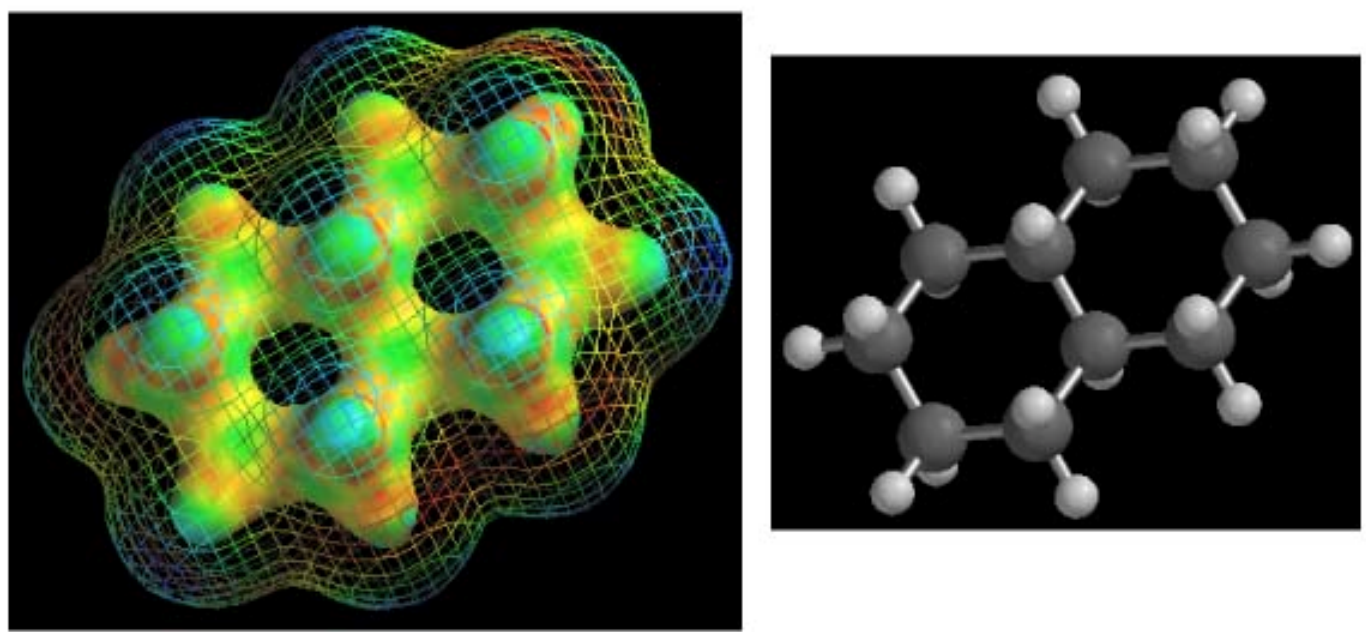

$\mathrm{C}_{10} \mathrm{H}_{18}$

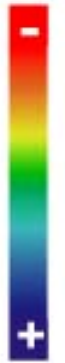

Charge

Distribution

\begin{tabular}{|r|c|}
\hline Surface Area of Molecule / $A^{2}$ & 184.50 \\
\hline Volume of Molecule/A & 170.89 \\
\hline Dipol moment/d & 0
\end{tabular}

Figure 14. Molecular representation of cis-decaline. 


\section{2-Methylnonane}
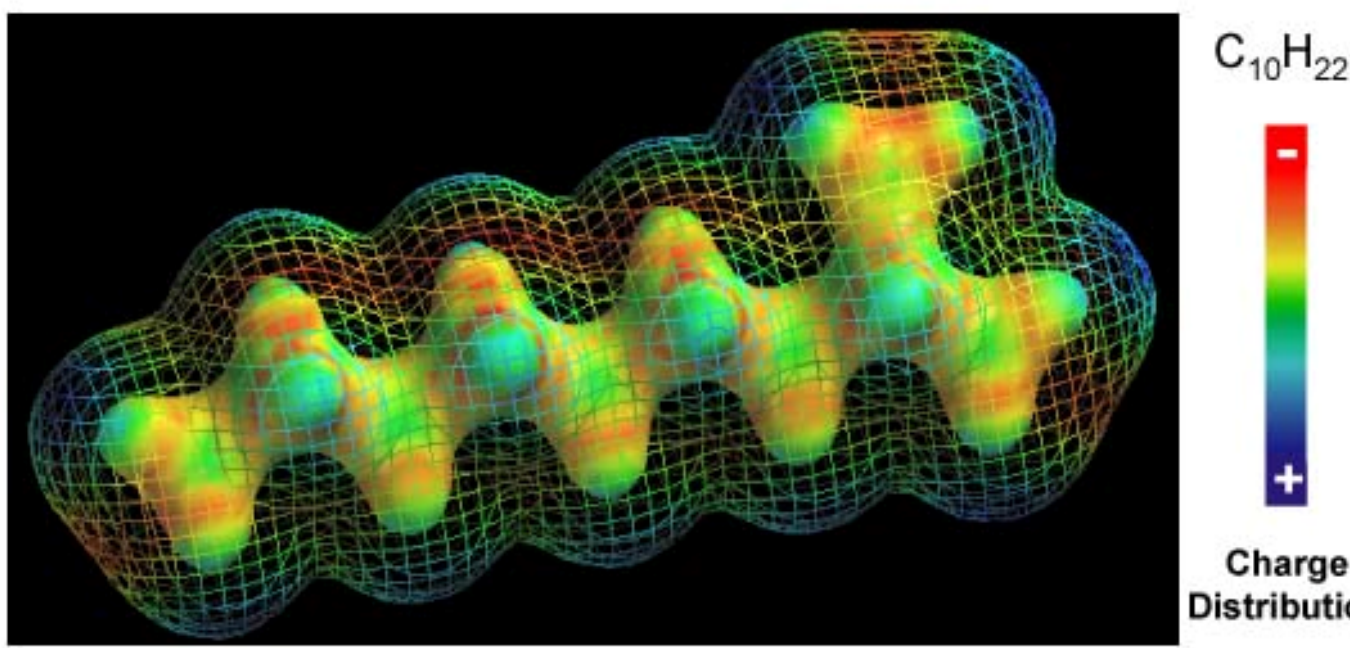

Charge Distribution

\begin{tabular}{|r|c|}
\hline Surface Area of Molecule / $A^{2}$ & 230.60 \\
\hline Volume of Molecule / $A^{3}$ & 197.63 \\
\hline Dipol moment/d & 0.1 \\
\hline
\end{tabular}

Figure 15. Molecular representation of 2-methylnonane.

\section{2-Methylnaphthalene}
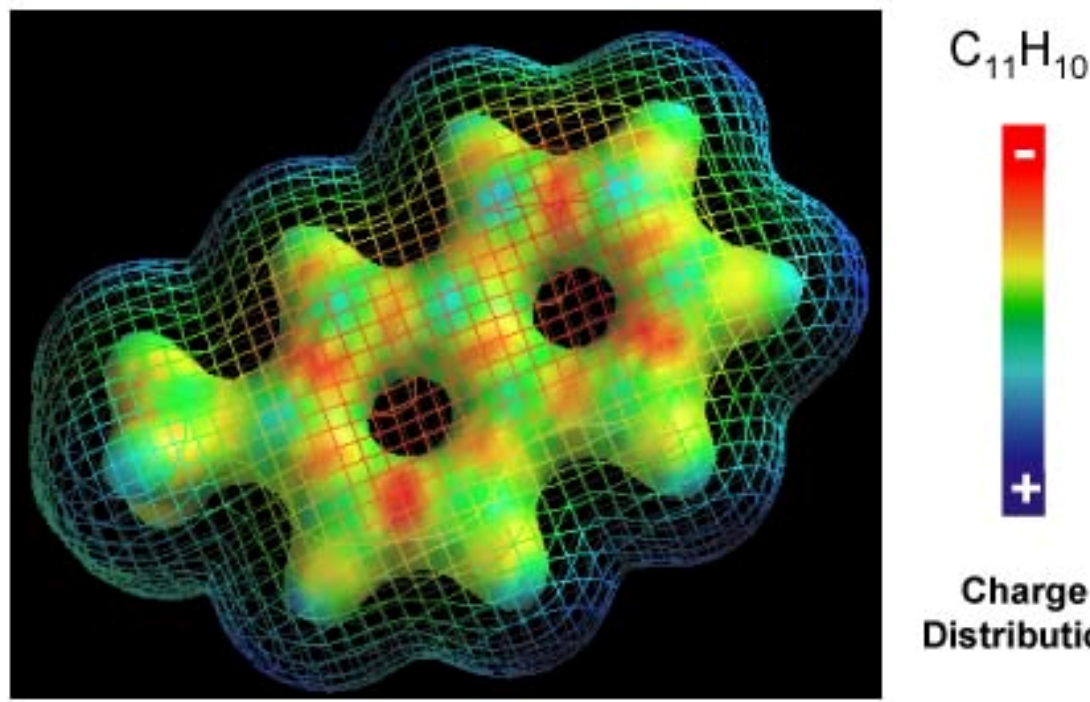

\section{Charge \\ Distribution}

\begin{tabular}{|r|c|}
\hline Surface Area of Molecule / $\mathrm{A}^{2}$ & 180.57 \\
\hline Volume of Molecule / $\mathrm{A}^{3}$ & 167.61 \\
\hline Dipol moment/d & 0.34 \\
\hline
\end{tabular}

Figure 16. Molecular representation of 2-methylnaphthalene. 
Decahydro-2-methylnaphthalene

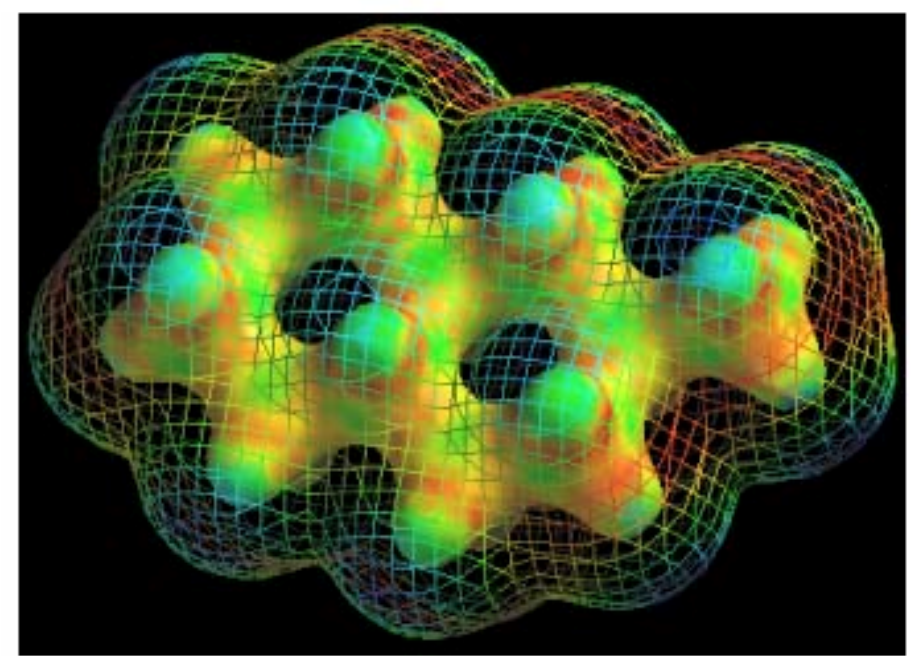

$\mathrm{C}_{11} \mathrm{H}_{20}$

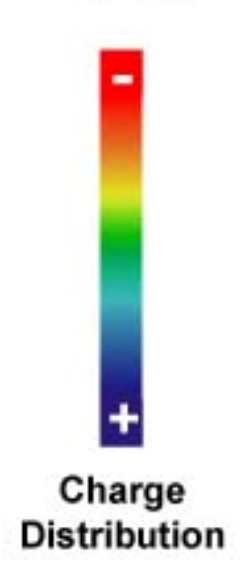

\begin{tabular}{|r|c|}
\hline Surface Area of Molecule / $\mathrm{A}^{2}$ & 203.58 \\
\hline Volume of Molecule/ $/ \mathrm{A}^{3}$ & 188.94 \\
\hline Dipol moment/d & 0.09 \\
\hline
\end{tabular}

Figure 17. Molecular representation of decahydro-2-methylnaphthalene.

\section{3-Methyldecane}
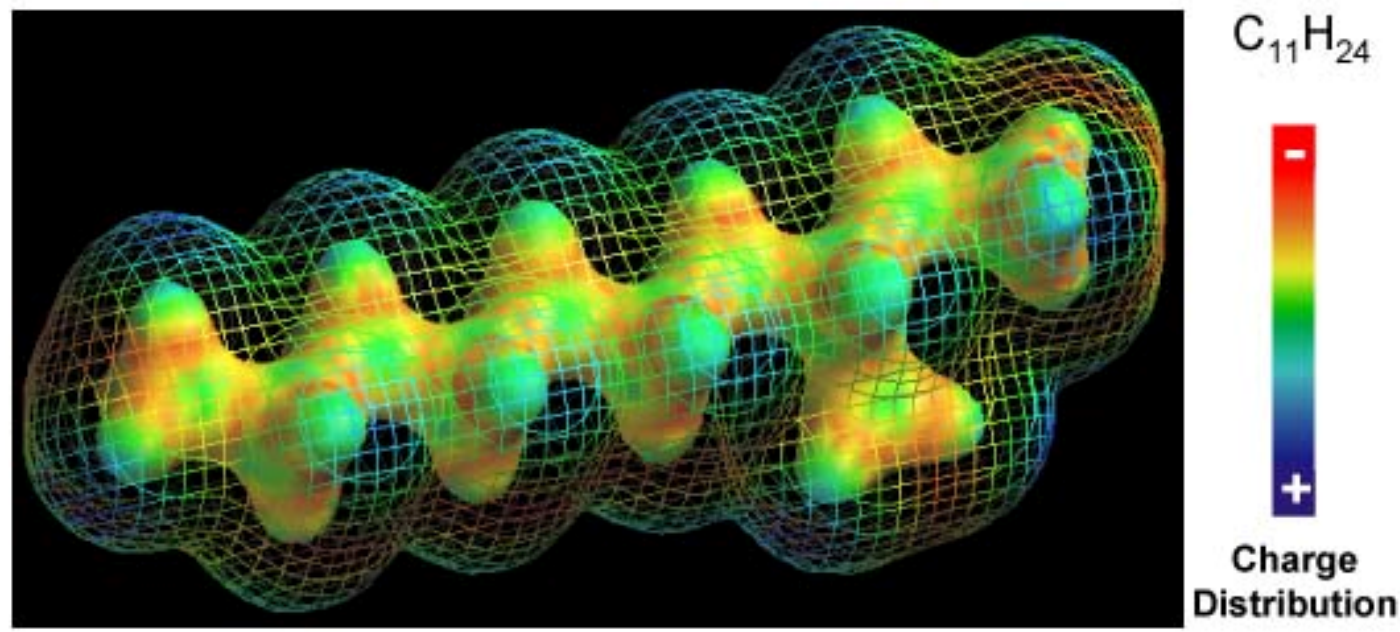

\begin{tabular}{|r|c|}
\hline Surface Area of Molecule / $\mathrm{A}^{2}$ & 249.55 \\
\hline Volume of Molecule / $\mathrm{A}^{3}$ & 215.88 \\
\hline Dipol moment $/ \mathrm{d}$ & 0.06 \\
\hline
\end{tabular}

Figure 18. Molecular representation of 3-methyldecane. 


\section{1-Dodecene}

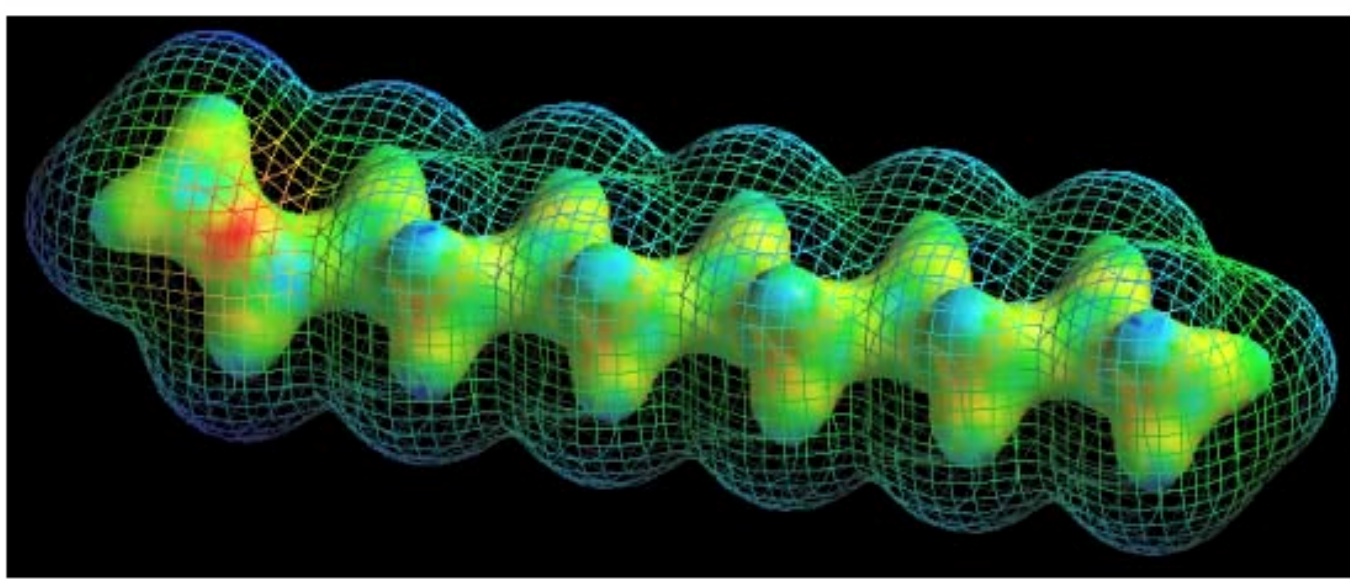

$\mathrm{C}_{12} \mathrm{H}_{24}$

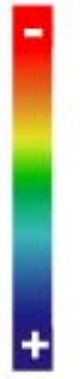

Charge

Distribution

\begin{tabular}{|r|c|}
\hline Surface Area of Molecule/A & 268.02 \\
\hline Volume of Molecule/A & 230.62 \\
\hline Dipol moment/d & 0.35 \\
\hline
\end{tabular}

Figure 19. Molecular representation of 1-dodecene.

\section{1,11-Dodecadiene}

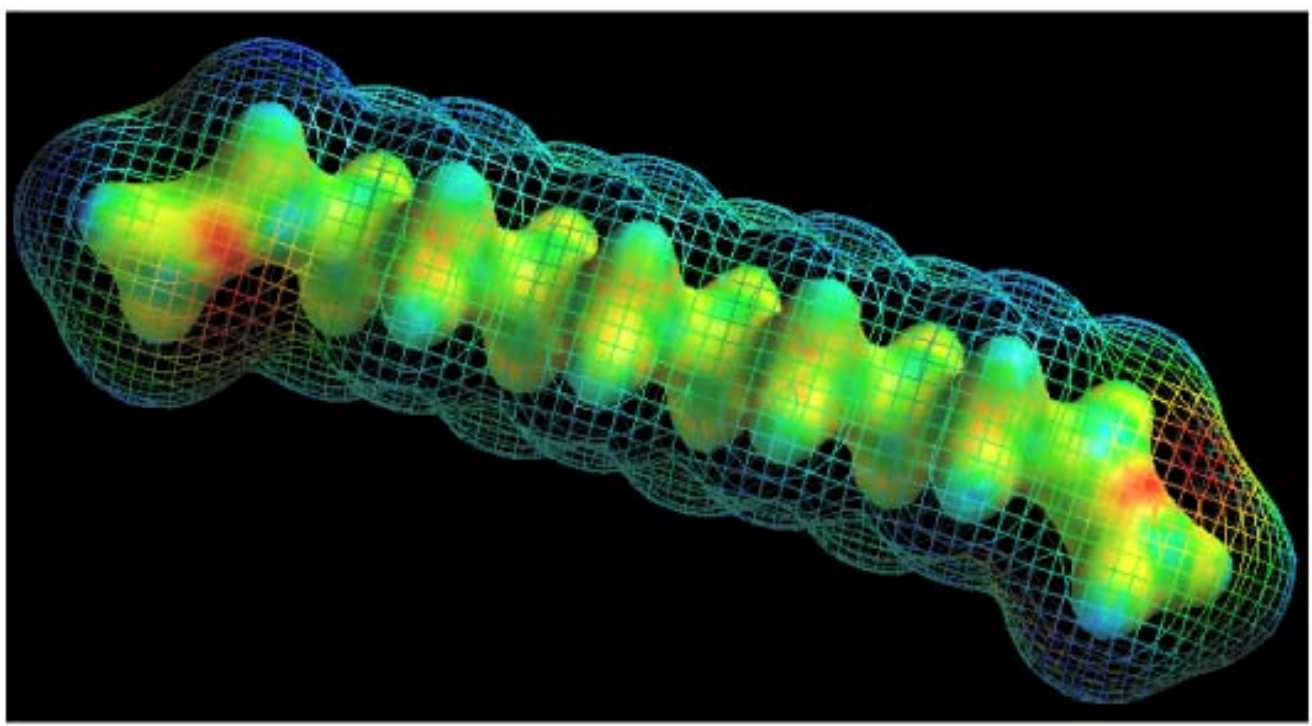

$\mathrm{C}_{12} \mathrm{H}_{22}$

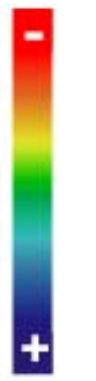

Charge

Distribution

\begin{tabular}{|r|c|}
\hline Surface Area of Molecule / $A^{2}$ & 263.10 \\
\hline Volume of Molecule/A & 226.61 \\
\hline Dipol moment/d & 0.26 \\
\hline
\end{tabular}

Figure 20. Molecular representation of 1,11-dodecadiene. 


\title{
Cyclododecane
}

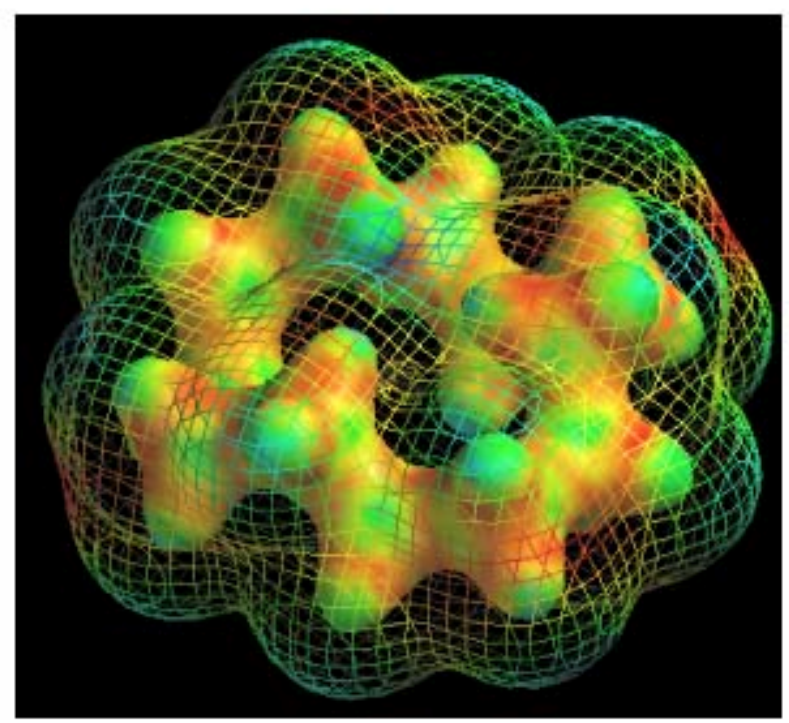

\author{
$\mathrm{C}_{12} \mathrm{H}_{24}$
}

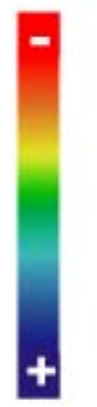

Charge

Distribution

\begin{tabular}{|r|c|}
\hline Surface Area of Molecule/A & 232.77 \\
\hline Volume of Molecule/A & 220.67 \\
\hline Dipol moment/d & 0.01 \\
\hline
\end{tabular}

Figure 21. Molecular representation of cyclododecane.

\section{Heptylcyclohexane}

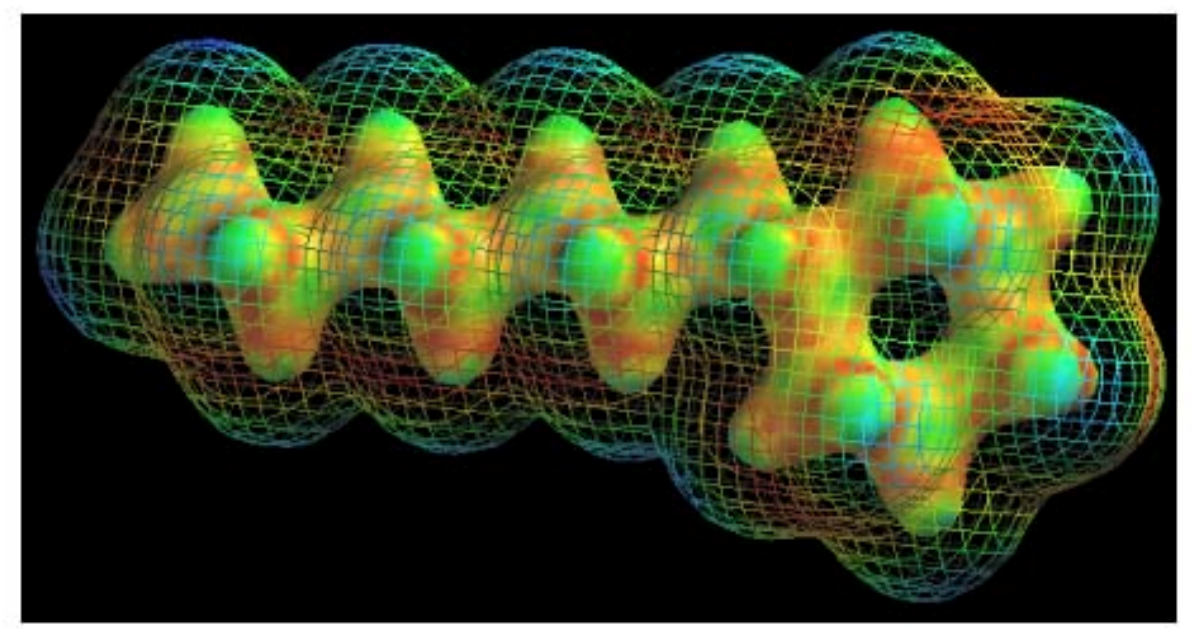

$\mathrm{C}_{13} \mathrm{H}_{26}$

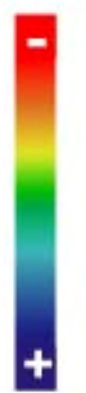

Charge

Distribution

\begin{tabular}{|r|c|}
\hline Surface Area of Molecule/A & 266.87 \\
\hline Volume of Molecule/A & 239.37 \\
\hline Dipol moment/d & 0.06 \\
\hline
\end{tabular}

Figure 22. Molecular representation of heptylcyclohexane. 


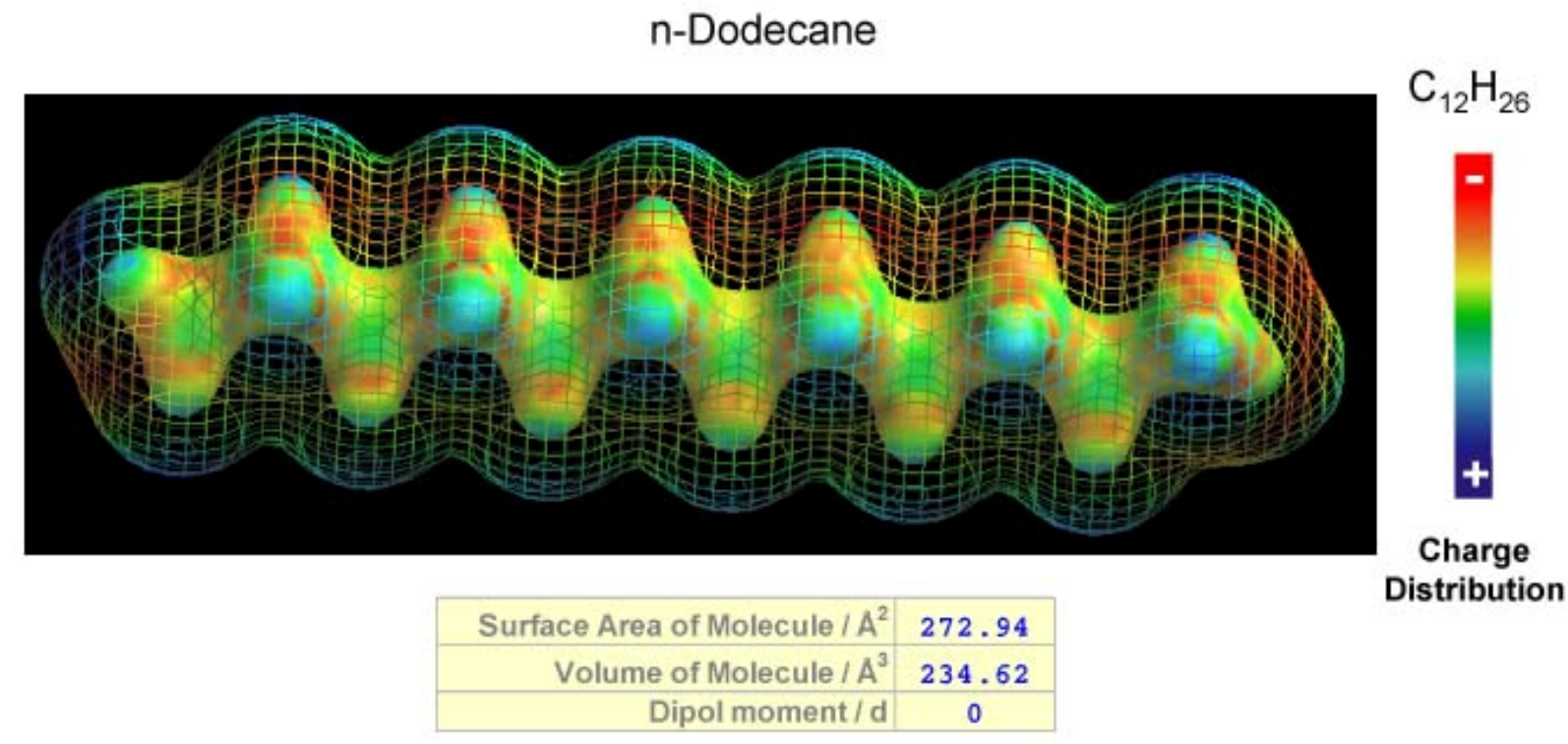

Figure 23. Molecular representation of $\mathrm{n}$-dodecane.

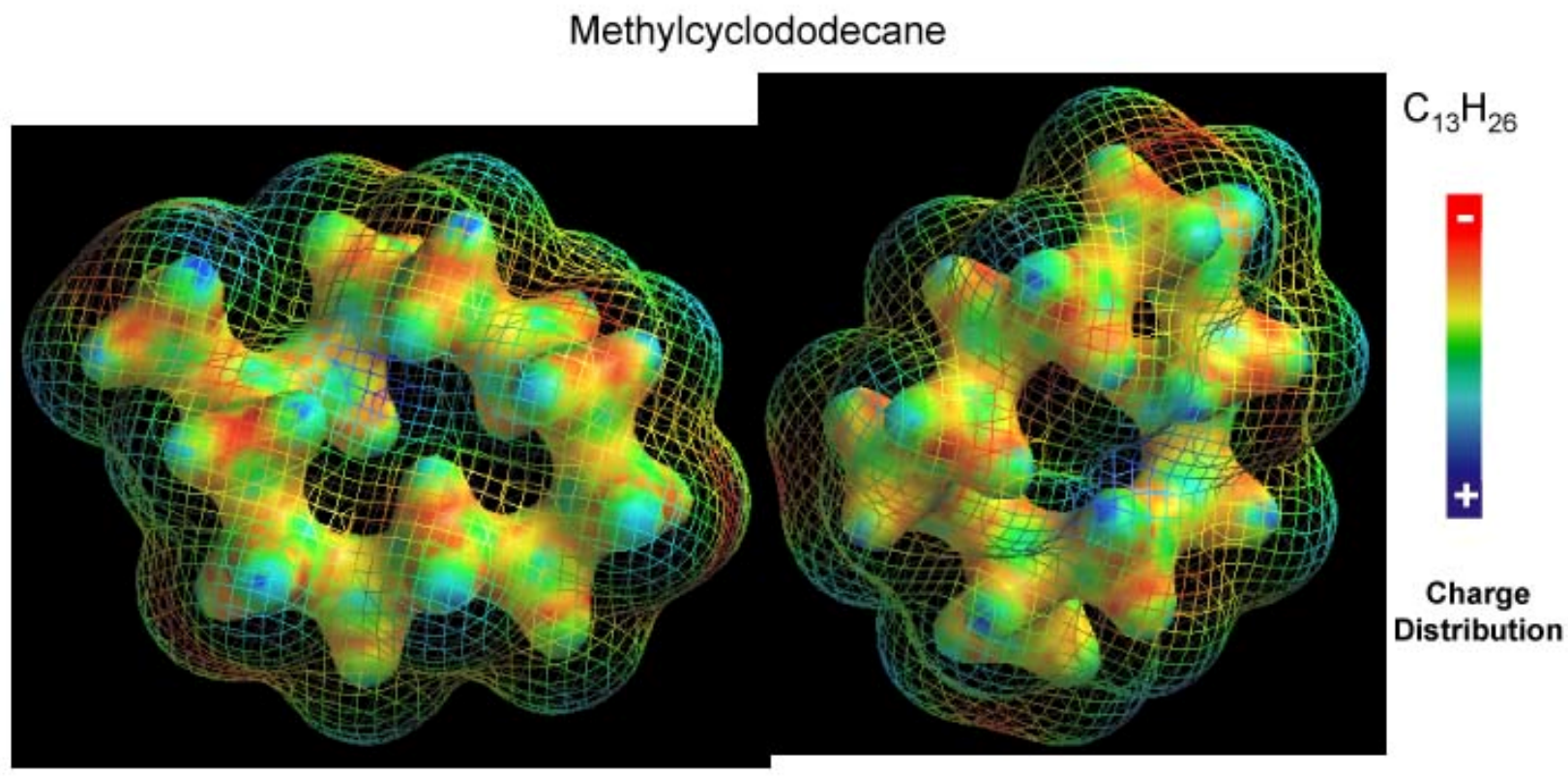

\begin{tabular}{|r|c|}
\hline Surface Area of Molecule / $A^{2}$ & 246.77 \\
\hline Volume of Molecule / $A^{3}$ & 237.57 \\
\hline Dipol moment/d & 0.04 \\
\hline
\end{tabular}

Figure 24. Molecular representation of methylcyclododecane. 


\section{1-Tridecene}

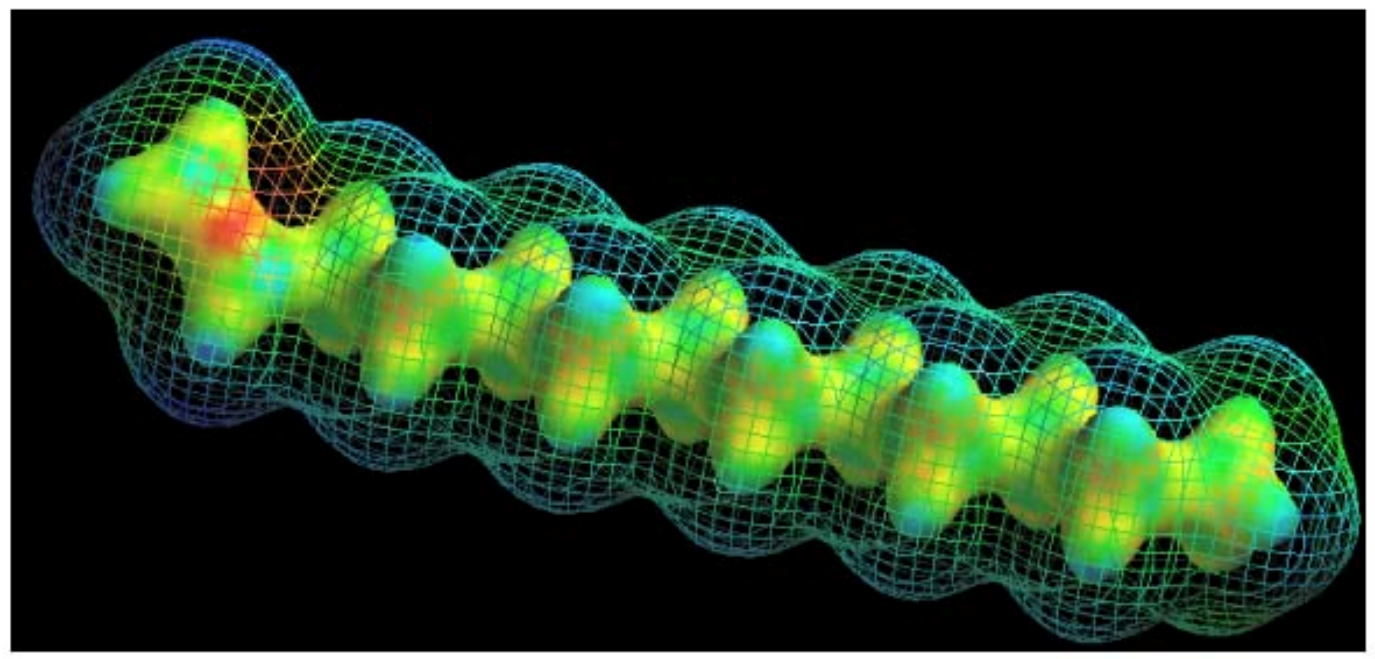

$\mathrm{C}_{13} \mathrm{H}_{26}$

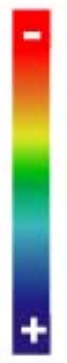

Charge Distribution

\begin{tabular}{rc} 
Surface Area of Molecule / $A^{2}$ & 288.12 \\
Volume of Molecule / $A^{3}$ & 248.93 \\
\hline Dipol moment/d & 0.34
\end{tabular}

Figure 25. Molecular representation of 1-tridecene.

\section{2,10-Dimethylundecane}

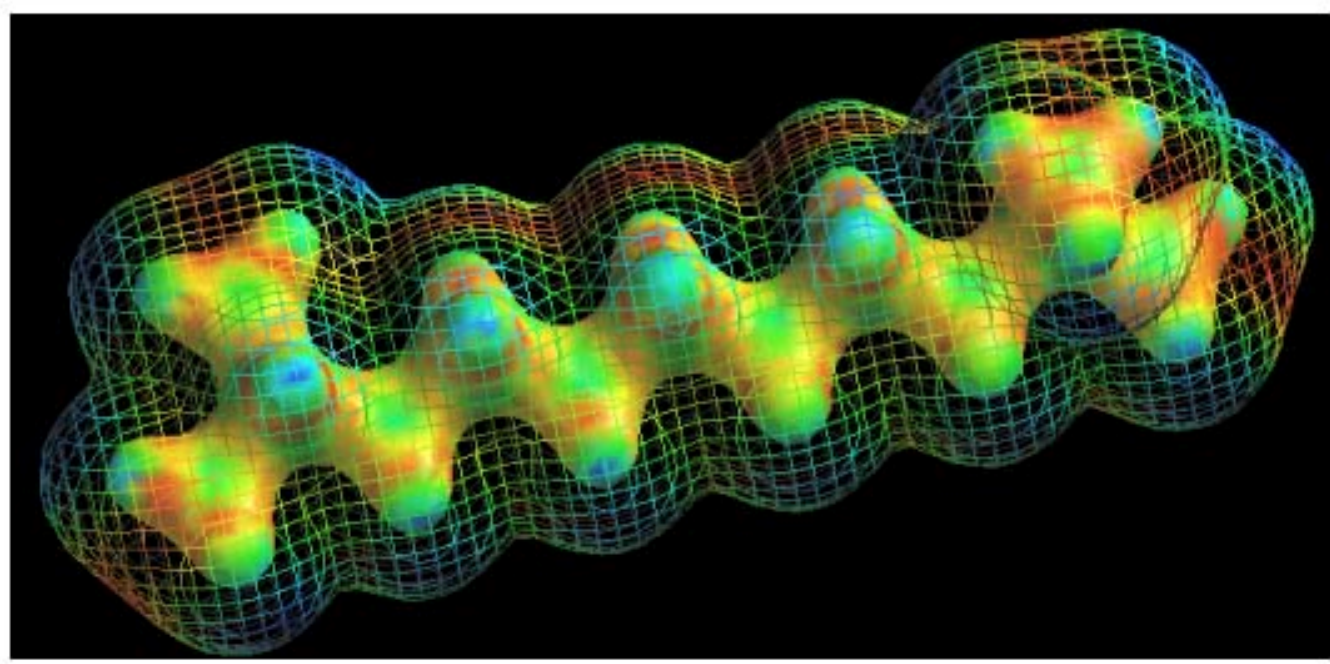

$\mathrm{C}_{13} \mathrm{H}_{28}$

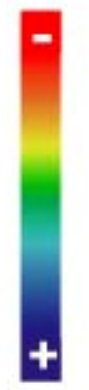

Charge Distribution

\begin{tabular}{|r|c|}
\hline Surface Area of Molecule / $\mathrm{A}^{2}$ & 288.76 \\
\hline Volume of Molecule/A & 252.2 \\
\hline Dipol moment/d & 0.08 \\
\hline
\end{tabular}

Figure 26. Molecular representation of 2,10-dimethylundecane. 


\section{2,7,10-Trimethyldodecane}

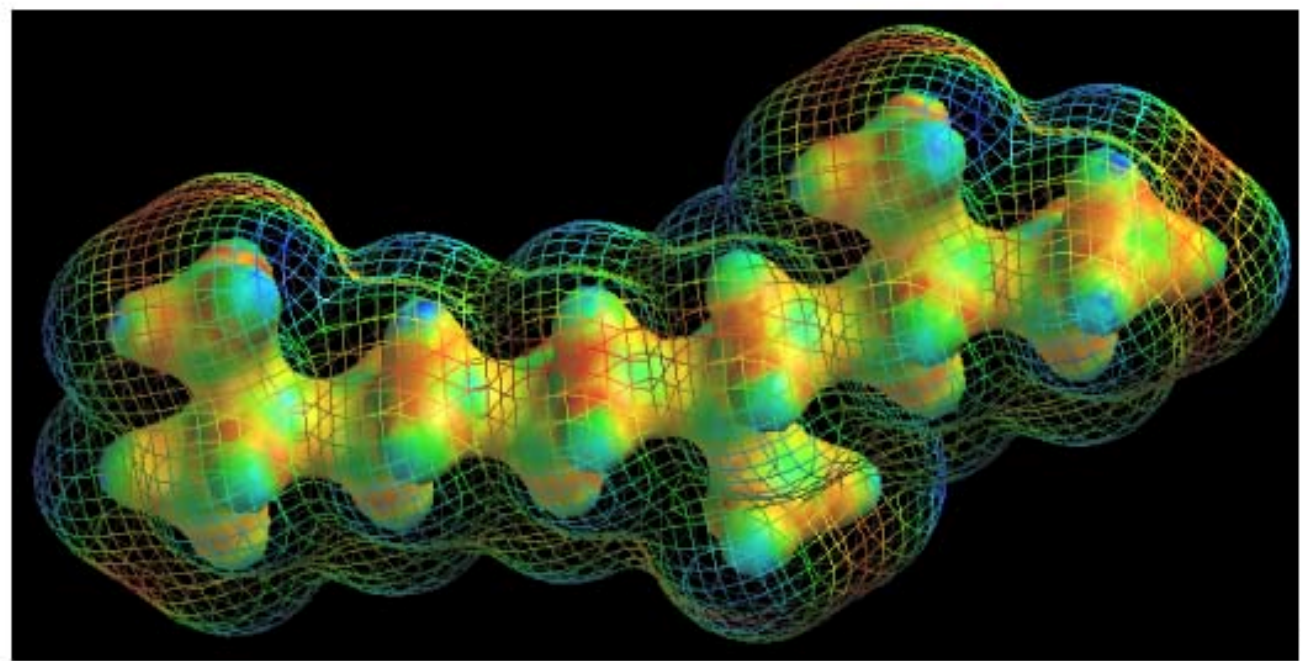

$\mathrm{C}_{15} \mathrm{H}_{32}$

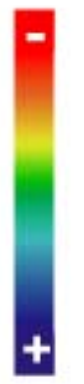

Charge

Distribution

\begin{tabular}{|r|c|}
\hline Surface Area of Molecule / $A^{2}$ & 324.25 \\
\hline Volume of Molecule/A & 288.36 \\
\hline Dipol moment/d & 0.07
\end{tabular}

Figure 27. Molecular representation of 2,7,10-trimethyldodecane.

n-Hexadecane

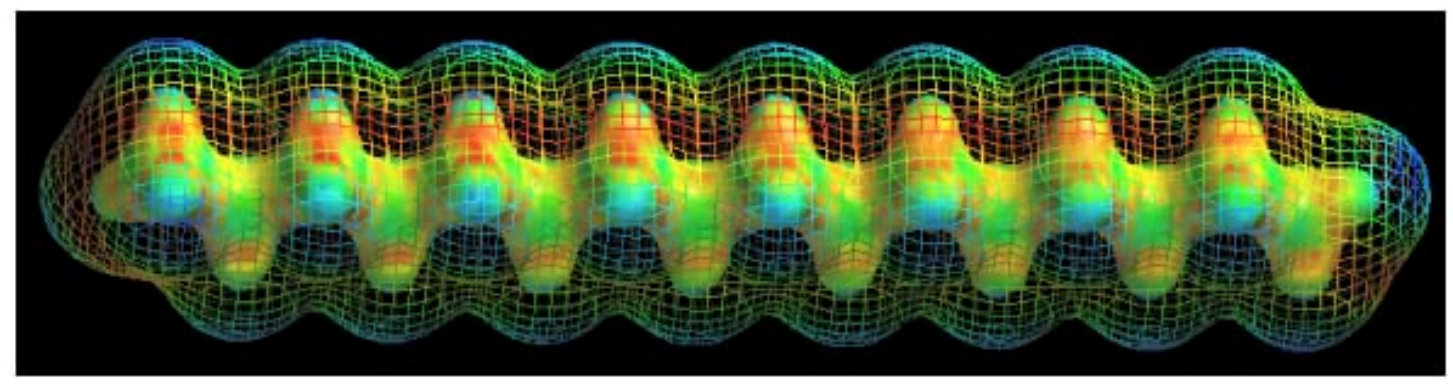

$\mathrm{C}_{16} \mathrm{H}_{34}$

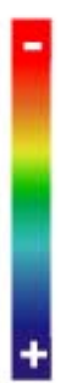

Charge Distribution

Figure 28. Molecular representation of n-hexadecane. 